\title{
Long-term Acoustic Assessment of Bats on Big Sheep Creek in the Tendoy Mountains of Southwest Montana and Management Recommendations for Bats
}

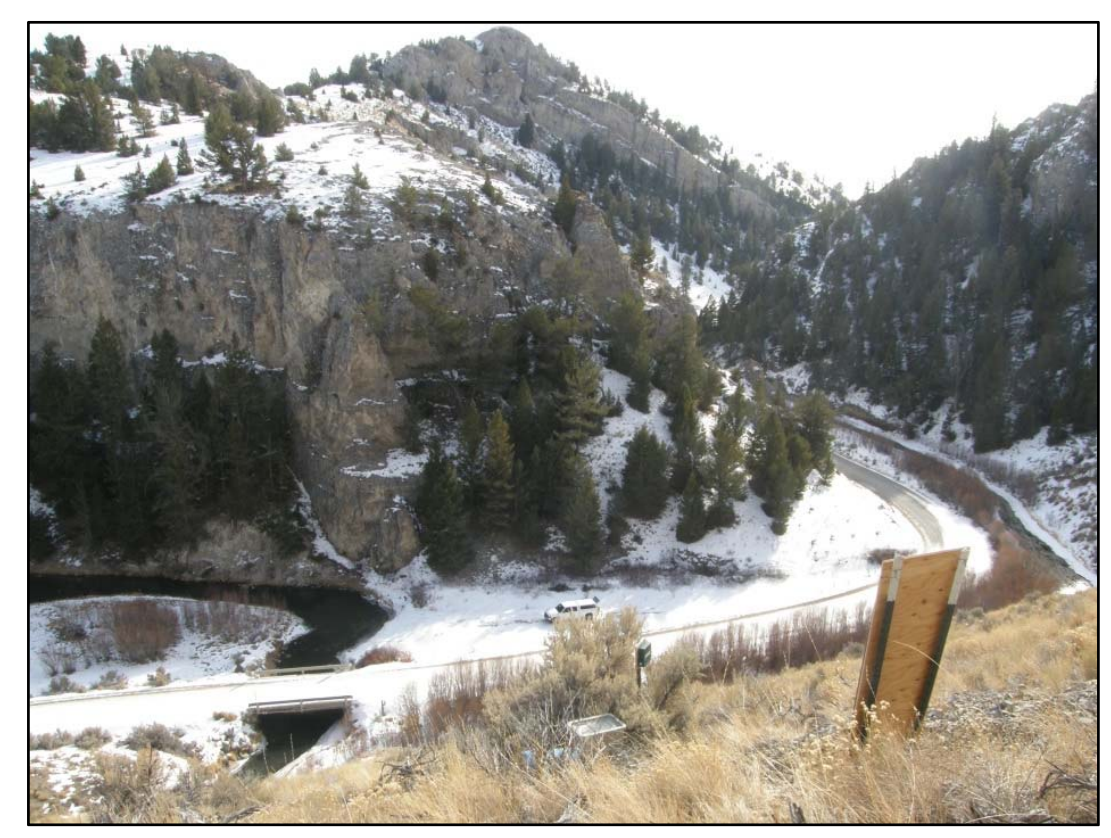

Prepared for:

Beaverhead-Deerlodge National Forest

and

Dillon Field Office of the Bureau of Land Management

Prepared by:

Bryce A. Maxell, Braden Burkholder, Shannon Hilty, and Scott Blum Montana Natural Heritage Program a cooperative program of the Montana State Library and the University of Montana 



\title{
Long-term Acoustic Assessment of Bats on Big Sheep Creek in the Tendoy Mountains of Southwest Montana and Management Recommendations for Bats
}

\author{
Prepared for: \\ Beaverhead-Deerlodge National Forest \\ 420 South Barrett Street \\ Dillon, Montana 59725 \\ and \\ Dillon Field Office \\ Bureau of Land Management \\ 1005 Selway Drive \\ Dillon, Montana 59725
}

Agreement Numbers:

14-CS-11015600, L09AC15419, and L13AC00026

Prepared by:

Bryce A. Maxell, Braden Burkholder, Shannon Hilty, and S. Blum
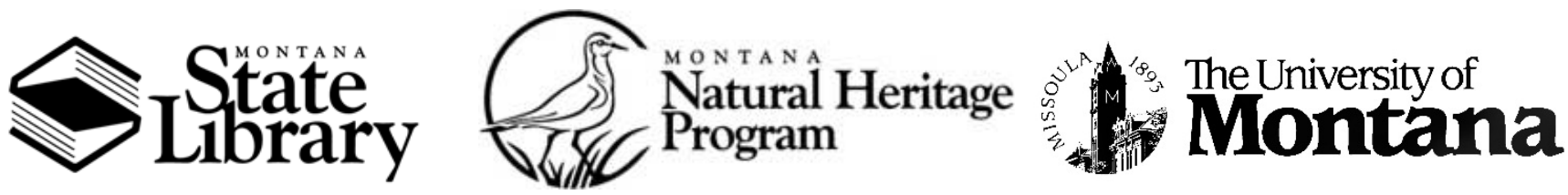

(c) 2016 Montana Natural Heritage Program

P.O. Box $201800 \bullet 1515$ East Sixth Avenue • Helena, MT 59620-1800 • 406-444-3290 
This document should be cited as follows:

Maxell, B.A., B. Burkholder, S. Hilty, and S. Blum. 2016. Long-term acoustic assessment of bats on Big Sheep Creek in the Tendoy Mountains of southwest Montana and management recommendations for bats. Report to Beaverhead-Deerlodge National Forest and Dillon Field Office of the Bureau of Land Management. Montana Natural Heritage Program, Helena, Montana 49 pp. plus appendices. 


\section{EXECUTIVE SUMmARY}

Montana's bat populations face a wide array of conservation issues, including loss of roosting sites, elimination of prey species, collision or drowning hazards at sites where they forage, drink, and mate, and a lack of baseline information on distribution and habitat use that is available to resource managers. In recent years, concerns have focused on fatalities at wind turbine facilities and those resulting from White-nose Syndrome (WNS). WNS has killed an estimated 5.7 to 6.7 million bats in eastern North America and 600,000 to 888,000 bats are estimated to have been killed at wind energy facilities across the United States in 2012 alone. These and other sources of mortality may be having significant impacts on bat populations because bats are long-lived and have only one or two young per year. Given these concerns, a long term acoustic detector was installed on Big Sheep Creek in the Tendoy Mountains in southwest Montana to gather baseline information on bats. This was one of the first ultrasonic acoustic detectors installed in what grew to become a regional network of detectors deployed over multiple years to document activity patterns of bats across Montana, and portions of northern Idaho, and the western Dakotas.

The overarching objectives of this project were to gather multiple years of year-round baseline information on: (1) bat species composition and activity levels; (2) timing of species immergence to and emergence from hibernacula for nonmigratory bat species; (3) timing of migrations by tree roosting migratory species that have been documented as having the highest levels of mortality from collisions with wind turbines; and (4) correlates of bat activity such as wind speed, temperature, precipitation, barometric pressure, and moon illumination.

We recorded bat echolocation calls from sunset to sunrise nightly with an SM2Bat+ detector/recorder mounted above Big Sheep Creek between 31 January 2012 and 24 October 2014. A total of 12,269 bat call sequences were recorded over 10,716 hours of monitoring, with 14.5 percent being auto-identified to species by Sonobat 3.0 or Kaleidoscope Pro 2.0 software.

Six species were definitively confirmed by hand review using the bat call characteristic identification guidelines in Montana's Bat and White-Nose Syndrome Surveillance Plan and Protocols: Big Brown Bat (Eptesicus fuscus), Silver-haired Bat (Lasionycteris noctivagans), Hoary Bat (Lasiurus cinereus), Western Smallfooted Myotis (Myotis ciliolabrum), Long-eared Myotis (Myotis evotis), and Little Brown Myotis (Myotis lucifugus). In addition, there were several call sequences recorded during the study that fit definitive characteristics of Yuma Myotis (Myotis yumanensis) calls. However, because this region is outside the range where the species has been documented with mist net captures, we believe it is best to regard all of these sequences as only potentially Yuma Myotis calls until there is genetic confirmation of the species in the region. While their presence could not be confirmed by this study, Townsend's Big-eared Bat and California Myotis should also both be regarded as potentially present in the Tendoy Mountains given their documented presence in adjacent areas of southwestern Montana. Finally, despite being 
detected in the Tendoy Mountains previously, Long-legged Myotis could not be confirmed by this study and should be regarded as present, but with a low likelihood of acoustic detection.

We documented the six species definitively detected in $\mathbf{2 0}$ monthly time periods in which there had been no previous documentation of their presence in the region, including threemonth expansions in documented activity periods for both Big Brown Bat and Long-eared Myotis, a five-month expansion for Silver-haired Bat, a one-month expansion for Hoary Bat, and four-month expansions for both Western Smallfooted Myotis and Little Brown Myotis.

Patterns of bat activity recorded at the Big Sheep Creek acoustic monitoring station were consistent with overall average bat activity patterns recorded across the regional network of acoustic detectors. Activity was very limited, $<1$ pass per night on average, between November and February. However, at least some bat activity was documented every month but January in at least one of the study years. Average nightly bat passes began to increase each year in mid to late April, reached a maximum of 56 to 65 bat passes per night between July and September after young became flighted and during migration and swarming, and were greatly reduced again by mid-October.

During the active season (April to October), some level of bat activity was evident throughout most of the nighttime hours. However, there was a major pulse of activity in the first hour after sunset and the vast majority of activity occurred during the first two to three hours after sunset. This may be a result of relatively cold nighttime temperatures at this relatively high elevation site.

Throughout the study maximum background and bat pass temperatures recorded at the detector closely approximated one another. However, average and minimum bat pass temperatures recorded at the detector were consistently much higher than average and minimum background temperatures; monthly averages ranged from 3 to $13.3^{\circ} \mathrm{C}$ higher and monthly minimums ranged from 1.3 to $24.2^{\circ} \mathrm{C}$ higher. Thus, bats consistently restricted their activity to warmer time periods from the range of background temperatures that were available to them.

A clear relationship between bat activity patterns at the detector and wind speed recorded at the Harkness weather station was hampered by the 20.1 kilometers separating the two stations. This data indicated that bats are more active at wind speeds of 3 to 7 meters per second than would be expected if bat activity was randomly distributed across all wind speeds available to them. A more reliable measure of bats responses to wind speeds may be evident in data spanning the entire detector network. This data shows bat activity as greater than expected at random for wind speeds less than 3 meters per second. Across the network, wind speeds less than 3 meters per second accounted for 73 percent of bat passes and wind speeds less than 6 meters per second accounted for 95 percent of bat passes.

Nearly 80 percent of bat activity was associated with little to no change ( -1 to +1 millibars) in hourly barometric pressure recorded at the Dillon Airport, located 74.4 kilometers to the north-northeast of the acoustic detector. 
However, bat activity was greater than would be expected in the negative pressure change classes down to -3 millibars of change per hour and was less than expected with neutral or positive changes up to 1 to 2 millibars per hour than if bat activity were randomly distributed across the background pressure change classes that were recorded. Across the detector network, 72 percent of bat activity was associated with little to no change (- 1 to +1 millibars) in hourly barometric pressure. However, bat activity was greater than expected during negative changes ( -1 to -3 millibars) in hourly barometric pressure and was less than expected with neutral or positive changes ( 1 to 2 millibars) in hourly barometric pressure than if it were randomly distributed across background pressure change classes.

Bat activity at the Big Sheep detector and at detectors across the regional network was distributed at random relative to background hours associated with and without precipitation at the nearest weather stations. This may simply be a result of the facts that: (1) nighttime precipitation events are relatively rare; (2) weather stations are often somewhat distant from the acoustic detectors; and (3) precipitation was coded in hourly bins while bats are capable of flight within minutes after the passage of a storm front. Thus, bat activity recorded at the Big Sheep Creek detector and many of the acoustic detectors across the network may be relatively meaningless with regard to precipitation events recorded at distant weather stations.

Patterns in the percent of hours with bat activity generally tracked patterns in the background percent of hours associated with various moon conditions. However, bat activity was much greater than would be expected during the full moon when it was above the horizon and at illumination levels of 0.8 to 1.0 when it was below the horizon than if bat activity had been randomly distributed across the various background moon illumination categories available. Across the regional network of bat detectors, an opposite pattern in bat activity was evident with progressively greater bat activity than would be expected at random when moon illuminations were less than 0.5 and progressively less bat activity than would be expected at random when moon illuminations were greater than 0.5. The Big Sheep Creek moon illumination results might, therefore, at first appear to be discordant with patterns across the region detector network. However, when one takes into account the fact that the Big Sheep Creek detector's microphone is mounted on a small cliff near the bottom of a canyon that would stay shaded from moon illumination unless the moon is directly overhead, it seems that the pattern observed at this detector is likely the exception that proves the rule that bats are shifting activity toward times or places that have lower moon illumination levels.

Identification of individual species activity patterns was hindered by relatively low and potentially inconsistent rates of autoidentification of call sequences to species. Thus, activity patterns for species from autoidentified call sequences should be regarded as speculative due to a variety of issues that might cause auto-identifications to be inaccurate and/or inconsistent. Of the four species for which there is at least some justification for showing potential patterns of documented activity from auto-identified call sequences, there were three main patterns evident in 
average nightly passes per week. First, recorded activity for all these species was reduced in 2013 and 2014 relative to what it was in 2012, apparently as a result of the loss in sensitivity of the microphone. Second, in 2012, Big Brown Bat, Western Small-footed Myotis, and Little Brown Myotis all had reduced activity through early June with less than one pass per night on average, higher levels of activity through early September or October with one to up to twenty-three passes per night on average, and then reduced activity with less than one pass per night on average during the winter of 2012-2013. Third, in contrast to the other species, recorded Silver-haired Bat activity began relatively early, lasted relatively late into the year, and had no major peaks or troughs.

The above measures of overall bat activity near the detector, hand confirmed presence of individual species by month, and hand confirmed minimum temperatures associated with bat passes of individual species are all stable metrics upon which management recommendations can be made. However, patterns of activity of individual species resulting from automated analyses should be used with a great deal of caution due to low rates of species assignment and low or uncertain rates of accuracy of those assignments. Furthermore, it should be noted that bat activity measured during this study was made by a microphone on a 9-10 foot mast at the top of a small cliff and may not have adequately sampled the activity of high flying bats such as the Hoary Bat and Silver-haired Bat, which have suffered high rates of mortality at wind turbines across North America.
The following management recommendations are based on information gathered during this study, literature and documentation in Montana's animal point observation database on the roosting habits and habitats of Montana's bat species (Appendix C, MTNHP 2016), compilations of literature on the impacts of wind turbines on bats (Table 1, Appendix A, see especially Schuster et al. 2015), and new voluntary best management practices adopted by the American Wind Energy Association.

Management recommendations include: (1) protecting potential natural roost sites by conserving large diameter trees (especially snags with loose bark), rock outcrops, cliff crevices, and caves; (2) maintaining accessibility for underground mine entrances that bats may be using as summer or winter roosts; (3) reducing structural complexity of vegetation (e.g., short stature grasslands) and availability of standing waters that might provide drinking opportunities for bats near wind turbines or other human structures that might represent a threat to bats or where bats are undesired; (4) if wind turbines are installed in the region, set turbine cut-in speeds to $\geq 6.0 \mathrm{~m} / \mathrm{sec}$ between April and October - especially important in July during peak bat activity when young are newly flighted, and August, September, and October when migratory species are passing through and local bats are swarming and breeding; (5) feather wind turbine blades, or making them parallel to wind direction, when wind speeds are $<6 \mathrm{~m} / \mathrm{sec}$ so that they rotate at fewer than 1-3 revolutions per minute between April and October; and (6) install bat houses on warm south and west facing walls of human structures to provide summer roosting habitat while avoiding bat use of internal portions of the structures. 


\section{ACKNOWLEDGEMENTS}

This project would not have been possible without grants administered by the Beaverhead-Deerlodge National Forest, Region One Office of the U.S. Forest Service, Dillon Field Office of the Bureau of Land Management, and the Montana/Dakotas State Office of the Bureau of Land Management. Amie Shovlain, Jolyn Ortega, Katie Benzel, and Jake Chaffin recognized the importance of gathering yearround baseline information on bat activity in the region, setup contracts, and provided feedback on project implementation. Amie Shovlain, with the Beaverhead-Deerlodge National Forest, and Katie Benzel with the Dillon Field Office of the Bureau of Land Management provided feedback on the detector location and checked and maintained the detector on numerous occasions. Staff at Wildlife Acoustics assisted with questions regarding the SM2Bat+ ultrasonic

detector/recorders and microphones and WAC to WAV and Kaleidoscope Pro software. Joe Szewczak provided Sonobat 3.0 software, feedback on its use, and the 2011 Humboldt State University Bat Lab's echolocation call characteristic summaries for western and eastern U.S. bats that we used to develop the call characteristic summary for Montana bats. John Horel with the MesoWest Research Group assisted with acquisition of weather station data through the MesoWest application programming interface. At the Montana Natural Heritage Program, Darlene Patzer assisted with grant administration, Susan Lenard assisted with hand review of bat calls, and Dave Ratz assisted with downloading of weather station data from the Mesowest application programming interface.

This project was supported by an agreements between the Region One Office of the U.S. Forest Service, The Dillon Field Office of the Bureau of Land Management, the Montana/Dakotas State Office of the Bureau of Land Management, and the Montana Natural Heritage Program, a cooperative program of the Montana State Library and the University of Montana (14-CS-11015600, L09AC15419, and L13AC00026) 


\section{TABLE OF CONTENTS}

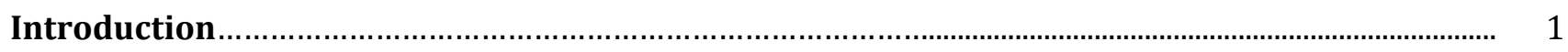

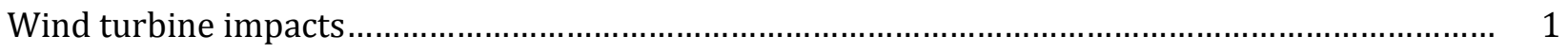

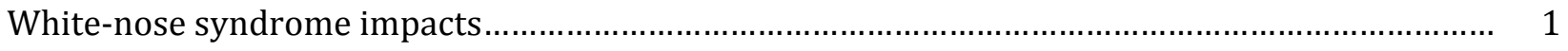

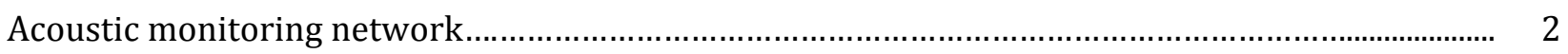

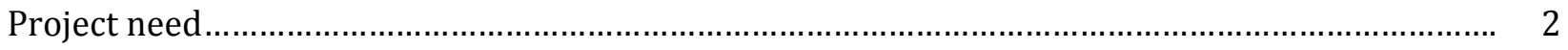

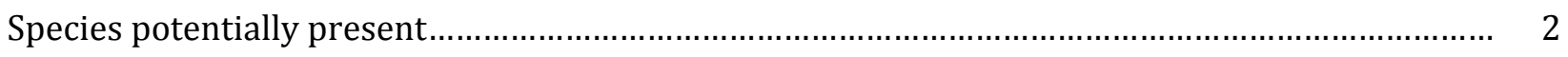

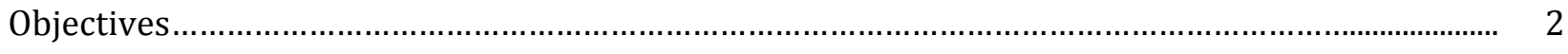

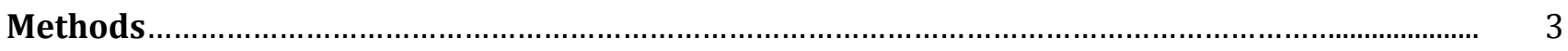

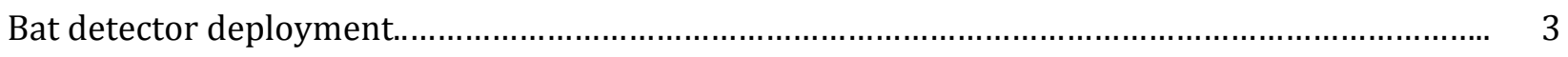

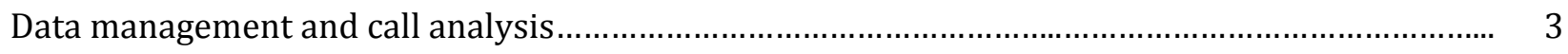

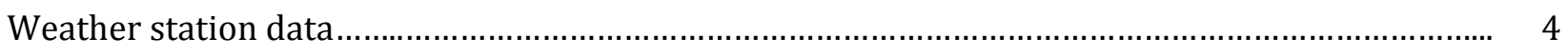

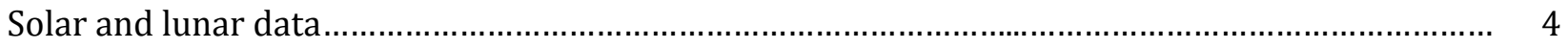

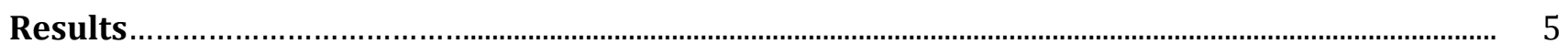

Total volume of bat passes and auto-identification rates..................................................... 5

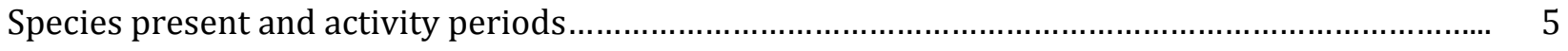

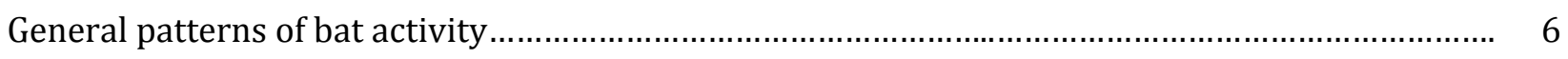

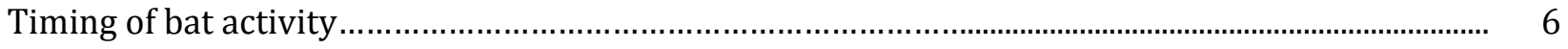

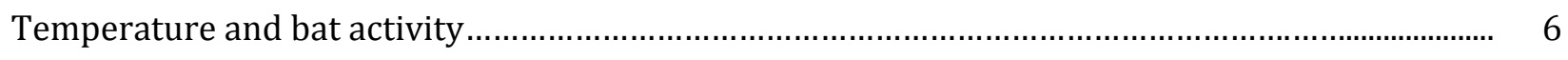

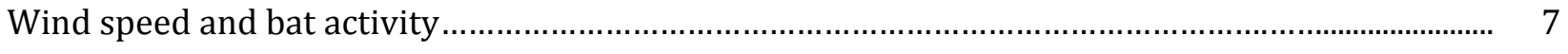

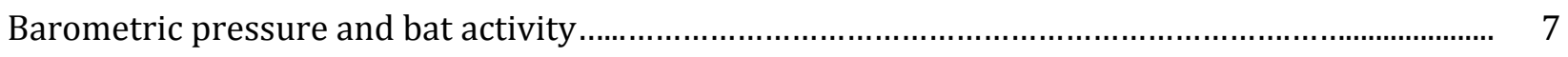

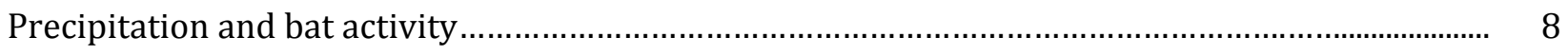

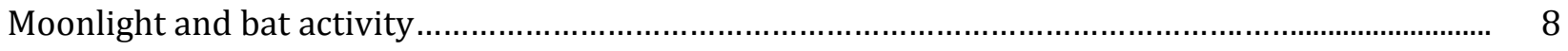

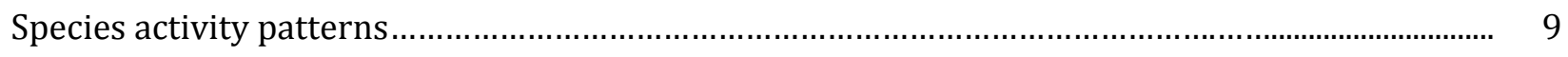

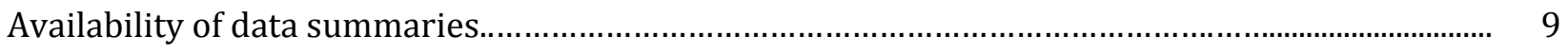

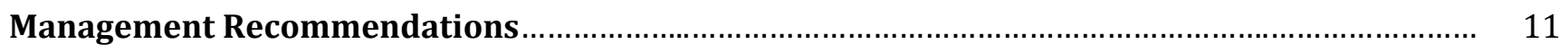

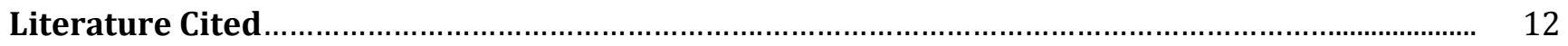




\section{LIST OF TABLES}

Table 1. Montana bat species, conservation status, and known or potential concerns from WNS and wind turbine facilities.

Table 2. Bat species present or potentially present in the Tendoy Mountains prior to and during this study

Table 3. Deployment history of SM2 Bat+ detector/recorder on Big Sheep Creek.

Table 4. Detector status as measured by percent of calls auto-identified to species.

Table 5. Monthly rates of hand confirmation from automated analysis results.

Table 6. Species definitively detected by month each year of the study.....

Table 7. Species definitively detected by month across the acoustic detector network and at the Big Sheep Creek detector

Table 8. Bat passes summarized by month across all species

Table 9. Nightly background and bat pass temperatures summarized by month......

Table 10. Monthly minimum bat pass temperatures recorded for individual species hand confirmed as definitively present

Table 11. Minimum bat pass temperatures recorded for definitive call sequences of species across the detector network and at the Big Sheep Creek detector 


\section{LIST OF FIGURES}

Figure 1. Network of long term ultrasonic acoustic detectors as December 2015 .............................

Figure 2. Location of the Big Sheep Creek detector recorder within the Tendoy Mountains and Harkness weather station at landscape and local views................................................... 28

Figure 3. Downslope and upslope views of bat detector on Big Sheep Creek.................................... 29

Figure 4. Percent of call sequences auto-identified to species each month....................................... 30

Figure 5. Average and maximum counts of bat passes per night by month........................................ 30

Figure 6. Average number of bat passes per night by week for active season and inactive season...... 31

Figure 7. Average number of bat passes per night by week across the detector network for active

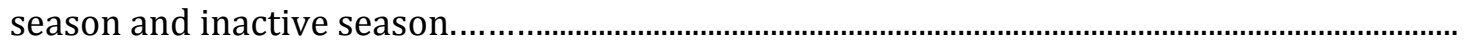

Figure 8. Total number of bat passes per night by week across the detector network and across all years for active season and inactive season as of fall 2015 .

Figure 9. Average number of bat passes each hour after sunset across all years during active and inactive season

Figure 10. Average nightly background and bat pass temperatures by month......

Figure 11. Percent of nightly hours with average background temperatures and average temperatures associated with bat passes for the Harkness weather station.

Figure 12. Percent of nightly hours with average background temperatures and average temperatures associated with bat passes across the regional network of detectors.....

Figure 13. Percent of hours with average background wind speeds and average wind speeds associated with bat passes at the Harkness weather station.

Figure 14. Percent of hours with average background wind speeds and average wind speeds associated with bat passes across the regional network of detectors

Figure 15. Percent of hours with background barometric pressure changes and barometric pressure changes associated with bat passes at the Dillon Airport weather station...................................

Figure 16. Percent of hours with background barometric pressure changes and barometric pressure changes associated with bat passes across the regional network of detectors.

Figure 17. Percent of background hours and hours with bat passes with and without precipitation at the Harkness weather station. 
Figure 18. Percent of background hours and hours with bat passes with and without precipitation

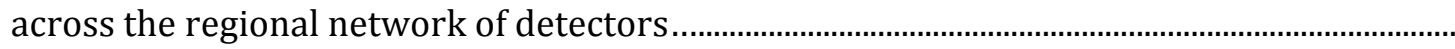

Figure 19. Percent of background hours and hours with bat passes at various moon illumination categories and with the moon above and below the horizon ........................................................

Figure 20. Percent of background hours and hours with bat passes associated with various moon illumination categories and with the moon below or above the horizon across the regional network of detectors. 45

Figure 21. Average number of nightly bat passes each week auto-identified as Big Brown Bat............. 46

Figure 22. Average number of nightly bat passes each week auto-identified as Silver-haired Bat.......... 47

Figure 23. Average number of nightly bat passes each week auto-identified as Western Small-footed Myotis....... 48

Figure 24. Average number of nightly bat passes each week auto-identified as Little Brown Myotis.... 49 


\section{APPENDICES}

Appendix A. References on wind turbine and other human structure collision impacts on bats...........

A $1-9$

Appendix B. Bat pass temperatures summarized by species and month for Big Sheep Creek..............

B 1-3

Appendix C. Overview of roosting habitat and home range / foraging distance documented for

Montana bat species. 


\section{INTRODUCTION}

Montana's bat populations face a wide array of conservation issues, including loss of roosting sites, elimination of prey species, collision or drowning hazards at sites where they forage, drink, and mate, and a lack of baseline information on distribution and habitat use that is available to resource managers. In recent years, concerns have focused on fatalities at wind turbine facilities and those resulting from White-nose Syndrome (WNS) (Table 1). The large increases in mortality posed by these threats are especially significant to bat populations because bats are long-lived and have only 1 or 2 young per year (Barclay and Harder 2003).

\section{WIND TURBINE IMPACTS}

Bat fatalities are widespread at wind energy facilities across the United States with 600,000 to 888,000 fatalities estimated in 2012 alone (Hayes 2013, Smallwood 2013). The widespread nature of these fatalities coupled with low fecundities of bats raise concerns that wind turbines may be having significant impacts on bat populations (Barclay and Harder 2003, Kunz et al. 2007, Arnett et al. 2008). Of North America's 45 documented bat species, mortalities from wind turbines have been documented in 11 and 5 of them potentially occur in the Tendoy Mountains for at least a portion of the year (Tables $1 \& 2$; Kunz et al. 2007, Arnett et al. 2008). Of these species, mortality rates have been highest ( $\geq 75 \%$ of mortalities) in tree roosting migratory species such as the Hoary Bat (Lasiurus cinereus) and Silver-haired Bat (Lasionycteris noctivagans) (Kunz et al. 2007, Arnett et al. 2008, Arnett et al. 2011). Thus, if wind turbines were to be installed in the region, the majority of mortalities would be expected to be associated with these two migratory tree roosting species during migratory events. However, resident bats may also be impacted (Poulton and Erickson 2010) and impacts may occur even during the winter (Lausen and Barclay 2006, this study).

\section{WHITE-NOSE SYNDROME IMPACTS}

Since 2006, White-Nose Syndrome, resulting from the cold adapted fungus Pseudogymnoascus destructans, has killed an estimated 5.7 to 6.7 million bats in eastern North America (Blehert et al. 2008, Lorch et al. 2011, USFWS News Release January 17, 2012, Minnis and Lindner 2013). As a result, the extinction of Little Brown Myotis (Myotis lucifugus) is predicted in eastern North America by 2026 (Frick et al. 2010), Little Brown Myotis, Northern Myotis (M. septentrionalis), and Tricolored Bat (Perimyotis subflavus) were emergency listed as Endangered under Canada's Species at Risk Act (COSEWIC 2012), Little Brown Myotis has been petitioned for emergency listing under the United States Endangered Species Act (Kunz and Reichard 2010), and Northern Myotis has been listed as Threatened under the United States

Endangered Species Act across its range, including nine eastern Montana counties (USFWS 2015). P. destructans has progressed westward to states along the Mississippi River corridor as well as the Province of Ontario, Canada, has caused WNS in at least three species documented in Montana, has been detected in other species that may serve as local or regional vectors, and seems likely to affect other Montana species due to the close relatedness of species that have been impacted (Table 1, Blehert et al. 2011, Heffernan 2014). 


\section{Acoustic Monitoring Network}

Starting in the fall of 2011, various federal, state, and tribal partners began deploying SM2Bat, SM2Bat+, and SM3Bat ultrasonic detector/recorders to gather year-round baseline information on bat activity in various localities across Montana. During 2012, individual efforts began to coalesce into a regional network of detectors to address most bat species known to occur in Montana (Figure 1, Table 1, Maxell 2015). Most of the recordings from this array are being processed, analyzed, and archived at the Montana Natural Heritage Program.

\section{Project Need}

Previous acoustic and mist net sampling for bats in southwestern Montana has been limited to single nights of sampling between late June and early September and no overwintering has been documented for bats in the Tendoy Mountains. Thus, the region lacked baseline data on yearround patterns of bat activity that could be used to inform resource management plans or individual projects.

\section{Species Potentially Present}

Of Montana's 15 known bat species, 8 had been documented in the vicinity of the Tendoy
Mountains prior to 2012: Big Brown Bat (Eptesicus fuscus), Silver-haired Bat (Lasionycteris noctivagans), Hoary Bat (Lasiurus cinereus), California Myotis (Myotis californicus), Western Small-footed Myotis (Myotis ciliolabrum), Longeared Myotis (Myotis evotis), and Little Brown Myotis (Myotis lucifugus) (Table 2). Two additional species are potentially present in the Tendoy Mountains as indicated by their presence in the surrounding region: Townsend's Big-eared Bat (Corynorhinus townsendii) and Yuma Myotis (Myotis yumanensis) (Table 2).

\section{OBjectives}

The major goals of this project were to: (1) gather baseline information on bat species composition and activity levels on Big Sheep Creek year round for 2-3 years; (2) identify timing of species immergence to and emergence from hibernacula for non-migratory bat species; (3) identify timing of migrations by tree roosting migratory species that have been documented as having the highest levels of mortality from collisions with wind turbines; and (4) identify relationships between bat activity and wind speed, temperature, precipitation, barometric pressure, and moon illumination. 


\section{METHODS}

\section{BAt Detector DePloyment}

The Tendoy Mountains were assessed for a location on public land with: (1) open water for as much of the year as possible; (2) rock outcrops and trees that might be used as roosts by bats; (3) southern solar exposure that would allow a solar panel to charge a battery even during the winter; (4) year-round access without too much travel by foot; and (5) a low likelihood of vandalism. An area along Big Sheep Creek met these criteria and on the afternoon of 31 January 2012 a Song Meter SM2Bat+ detector/recorder (Wildlife Acoustics Inc., Maynard, MA) was deployed adjacent to the stream with the microphone at the top of a small cliff at the edge of the stream and the detector/recorder, battery, and solar panel approximately 50-meters up the slope to the north of the creek (Table 3, Figures 1-3). Overall, this detector was fully operational for a total of 930 nights and 10,716 hours between 31 January 2012 and 24 October 2014 (Table 3).

The SM2Bat+ detector/recorder was deployed, monitored, and maintained with the equipment, supplies, settings, and protocols listed in Montana's Bat and White-Nose Syndrome Surveillance Plan and Protocols 20122016 (Maxell 2015).

A variety of factors influence the detection of a bat echolocation call and the quality of the resulting recording. These include sensitivity of the individual microphone, temperature, humidity, wind speed, and frequency, amplitude, distance, and directionality of echolocation calls emitted by bats (Parsons and Szewczak 2009, Agranat 2014). The energy of sounds spreading in all directions diminishes by one fourth for every doubling of distance because the surface area of a sphere is related to the square of its radius. Furthermore, higher frequency sounds are diminished over shorter distances because of atmospheric absorption (Parsons and Szewczak 2009, Agranat 2014). Testing of the SMX-US microphones used in this study indicates that bats emitting frequencies in the range of $20 \mathrm{kHz}$ should be detected at distances of 24 to 33 meters from the microphone while those emitting frequencies in the range of $40 \mathrm{kHz}$ should be detected at distances of 18 to 22 meters (Agranat 2014). These distances are the radii of the relevant spheres of detection around microphones when they are at full sensitivity. However, we know that sensitivity varied over time by an unknown magnitude as a result of precipitation and freezing events, some of which permanently reduced the sensitivity of microphones (Table 3).

\section{Data Management \& Call Analyses}

Acoustic file recordings, in both original WAC and processed WAV formats, are stored in the Montana Bat Call Library which is housed on a series of 15-20 Terabyte Drobo 5D and 5N storage arrays at the Montana State Library as well as a secondary offsite location to protect against catastrophic loss. Acoustic analysis results, temperature files, weather station data, and solar and lunar data were all processed and combined within SQL database tables in accordance with the general work flow pattern for data management and analysis outlined in the text and in Appendices 8-10 of Maxell (2015). Bat call sequences were analyzed with the goal of definitively identifying individual species presence by month and individual 
species' minimum temperatures of activity in accordance with the Echolocation Call Characteristics of Montana Bats and Montana Bat Call Identification materials in Appendices 6 and 7 of Montana's Bat and White-Nose Syndrome Surveillance Plan and Protocols 20122016 (Maxell 2015).

\section{Weather Station Data}

Weather station data were downloaded using the Mesowest application programming interface as outlined in Appendix 9 of Maxell (2015). Temperature, wind speed, and precipitation data were downloaded from the Harkness weather station $(44.465,-112.95194)$ which is located 20.1 kilometers southwest of the detector/recorder. Temperature, wind speed, and precipitation data were available for $94.6 \%, 94.6 \%$, and $94.5 \%$ of the hours of detector deployment, respectively. Barometric pressure data were downloaded from the Dillon Airport weather station (45.2575, -112.55444) which is located 74.4 kilometers northnortheast of the detector/recorder. Barometric pressure data was available for $97.4 \%$ of the hours of detector deployment.

\section{SOLAR AND LUNAR DATA}

Solar and lunar data were calculated for all hours of detector deployment using the Python package ephem (3.7.6.0), which uses wellestablished numeric routines to produce highprecision astronomy computations (see Appendix 10 of Maxell 2015). The underlying code produces results nearly identical to data available from the U.S. Naval Observatory (Astronomical Applications Department). Precise times for sunrise, sunset, moonrise, moonset, and percent illumination at the detector were calculated based on latitude, longitude, and date. It should be noted that local topography is not incorporated into any of these calculations. Therefore, the exact timing of these events on the ground may differ slightly from those produced by this model, but should typically be within a few minutes unless local terrain differs greatly from the modeled horizon (e.g. if the site is at the bottom of a canyon). 


\section{Results}

Total Volume of Bat Passes AND AUTO-IDENTIFICATION RATES

Between 31 January 2012 and 24 October 2014, a total of 12,269 bat call sequences were recorded, with 14.5 percent (monthly range 0.0 to 56.5 percent) auto-identified to species by Sonobat 3.0 or Kaleidoscope Pro 2.0 software. Overall rates of auto-identification were significantly lower than the regional network average of 23.7 percent for many months of the study (Table 4, Figure 4). The overall low autoidentification rates may be a result of microphone placement relative to the typical flight corridor of bats along this particular section of Big Sheep Creek (Figure 3). The microphone was placed at the top of a cliff and it is possible that bats flying close to the water were at the outer margin of the microphone's ability to detect complete diagnostic call sequences (Maxell 2015). It is also possible that a decline in microphone sensitivity after the spring of 2013, likely due to rain events, hampered recording fully diagnostic call sequences (Tables 3 \& 4, Figure 5, Maxell 2015).

\section{Species Present \& Activity Periods}

Of the call sequences auto-identified to species, more than 600 were fully reviewed by hand. Of the 107 months with calls auto-identified to ten different species, 62 months (58 percent) were confirmed by hand review for six species (Table 5). Big Brown Bat, Silver-haired Bat, Hoary Bat, Western Small-footed Myotis, Long-eared Myotis, and Little Brown Myotis had relatively high rates of monthly hand confirmation (43.8 to 100 percent) (Table 5). Despite having autoidentified call sequences and potentially being present in the region, Townsend's Big-eared Bat and California Myotis could not be confirmed with a definitive call sequence (Tables 2 \& 5, Maxell 2015). Townsend's Big-eared Bat has not been previously documented in the region with either mist net or acoustic surveys and California Myotis has only been documented with a single acoustic record (Table 2, MTNHP 2016). We believe that both of these species should be regarded as potentially present in the Tendoy Mountains because of previous documentation in nearby areas of southwestern Montana (Table 2, MTNHP 2016). We also classified two call sequences that were autoidentified as Yuma Myotis as probable and two other sequences met all the definitive characteristics of Yuma Myotis. However, because this region is outside the range where the species has been documented with mist net captures, we believe it is best to regard all of these sequences as only potentially Yuma Myotis until there is genetic confirmation of the species in the region (Table 2, MTNHP 2016). Long-legged Myotis has been confirmed in the Tendoy Mountains previously and a number of call sequences were auto-identified as this species. However, none of these call sequences met the definitive characteristics to confirm this species' presence. We therefore feel that this species should be regarded as present in the Tendoy Mountains with a low likelihood of acoustic detection (Tables 2 \& 6, MTNHP 2016, Maxell 2015).

We documented the six species definitively detected in $\mathbf{2 0}$ monthly time periods in which there had been no previous documentation of their presence in the region, including threemonth expansions in documented activity periods for both Big Brown Bat and Long-eared Myotis, a five-month expansion for Silver-haired Bat, a one-month expansion for Hoary Bat, and 
four-month expansions for both Western Smallfooted Myotis and Little Brown Myotis (Table 6).

As compared to the regional network of acoustic detectors, most of the species definitively confirmed at the Big Sheep detector had reduced (three to seven month) periods of confirmed activity and there was little to no confirmation of species and limited bat activity in general between November and February (Tables $7 \&$ 8). Limited detection during these colder time periods may indicate that many species that are year-round residents in Montana either move away from this high elevation region during these colder months or have local winter roosts that are somewhat distant from the location of the acoustic monitoring station and do not often travel far enough during winter rehydration flights to be detected.

\section{General Patterns of Bat Activity}

The patterns of activity recorded at the Big Sheep Creek acoustic monitoring station were consistent with overall average bat activity patterns recorded across the regional network of acoustic detectors (Table 8, Figures 5-7). Bat activity was very limited, $<1$ pass per night on average, between November and February. However, at least some bat activity was documented every month but January in at least one of the study years (Tables 6-8, Figures $5 \& 6)$. Average nightly bat passes began to increase each year in mid to late April, reached a maximum of 56 to 65 bat passes per night between July and September after young became flighted and during migration and swarming, and were greatly reduced again by mid-October (Table 8, Figures 5 \& 6, Parsons et al. 2003). While active season patterns were similar across the study, the average number of nightly passes recorded during the 2012 active season was greater than what was recorded in the 2013 and 2014 active seasons, apparently as a result of the loss in microphone sensitivity (Tables $3 \& 8$, Figures 5 \& 6).

\section{Timing OF BAT ACTIVITY}

During the active season (April to October), some level of bat activity was evident throughout most of the nighttime hours. However, there was a major pulse of activity in the first hour after sunset and the vast majority of activity occurred during the first two to three hours after sunset (Figure 9a). This may be a result of relatively cold nighttime temperatures at this relatively high elevation site. This hypothesis is supported by the fact that fewer nighttime hours had activity during the colder months of April and October and activity was further reduced during these months in later nighttime hours (Figure 9a). Similarly, during the inactive season (November to April), bat activity was almost solely limited to the first two to three hours after sunset (Figure 9b).

\section{TEMPERATURE \& BAT ACTIVITY}

Nightly average bat pass temperatures recorded at the detector ranged from 6.4 to $19.4^{\circ} \mathrm{C}$ during the active season and 3.0 to $8.5^{\circ} \mathrm{C}$ during the inactive season (Table 9).

Throughout the study maximum background and bat pass temperatures recorded at the detector closely approximated one another (Table 9). However, average and minimum bat pass temperatures recorded at the detector were consistently much higher than average and minimum background temperatures; monthly averages ranged from 3 to $13.3^{\circ} \mathrm{C}$ higher and monthly minimums ranged from 1.3 to $24.2^{\circ} \mathrm{C}$ higher (Table 9, Figure 10 ). Similarly, the distribution of temperatures recorded at the Harkness weather station, located 20.1 
kilometers to the southwest of the detector, that were associated with bat passes was significantly higher than the distribution of background temperatures (Figure 11). Thus, bats consistently restricted their activity to warmer time periods from the range of background temperatures that were available to them. This same pattern holds across the entire detector network with more than 99 percent of bat activity restricted to temperatures above freezing and 97 percent of bat activity restricted to temperatures above $5^{\circ} \mathrm{C}$ (Figure 12).

Monthly minimum bat pass temperatures confirmed for individual species ranged from 2.2 to $19.3^{\circ} \mathrm{C}$ for Big Brown Bat, 4.4 to $19.9^{\circ} \mathrm{C}$ for Hoary Bat, 3.1 to $19.6^{\circ} \mathrm{C}$ for Silver-haired Bat, 6.2 to $19.9^{\circ} \mathrm{C}$ for Western Small-footed Bat, 6.7 to $22.9^{\circ} \mathrm{C}$ for Long-eared Myotis, and 8.5 to $20.3^{\circ} \mathrm{C}$ for Little Brown Myotis (Tables 10 \& 11, Appendix $B$ ). The minimum bat pass temperatures recorded for individual species at the Big Sheep Creek acoustic detector were 5 to $11.3^{\circ} \mathrm{C}$ higher than have been recorded on other detectors across the region network todate (Table 11, Appendix B). This possibly indicates that roost sites for most species are somewhat distant from the detector location and that bats may not be flying far from their roost sites during colder weather conditions in this relatively harsh high elevation landscape.

\section{Wind SPEED \& BAT ACTIVITY}

Bat activity patterns in relation to wind speed recorded at the Harkness weather station, located 20.1 kilometers to the southwest of the acoustic detector, indicate that bats are more active at wind speeds of 3 to 7 meters per second than would be expected if bat activity was randomly distributed across all wind speeds available to them. Furthermore, only a tiny fraction of activity was associated with wind speeds of 10 meters per second or more (Figure 13). There were also clearly unlikely associations in the Harkness weather station data with some bat activity associated with wind speeds of up to 17 meters per second, more than 5 percent of passes associated with wind speeds greater than 8 meters per second, and less bat activity than would be expected at random for wind speeds at or below 2 meters per second (Figure 13). These seemingly anomalous results are likely due to the large distance between the Harkness weather station and the acoustic detector on Big Sheep Creek.

Across the entire detector network, bat activity was greater than expected at random for wind speeds less than 3 meters per second (Figure 14). Wind speeds less than 3 meters per second accounted for 73 percent of bat passes and wind speeds less than 6 meters per second accounted for 95 percent of bat passes (Figure 14). Given the relatively large distance between some bat detectors and weather stations (e.g., the Big Sheep Creek detector and Harkness weather station), it seems likely that, if anything, bats probably restrict their flight to even lower wind speeds than the associations in Figures 13 \& 14 indicate.

\section{Barometric Pressure \& ACTIVITY}

Nearly 80 percent of bat activity was associated with little to no change ( -1 to +1 millibars) in hourly barometric pressure recorded at the Dillon Airport, located 74.4 kilometers to the north-northeast of the acoustic detector. However, bat activity was greater than would be expected in the negative pressure change classes down to -3 millibars of change per hour and was less than expected with neutral or 
positive changes up to 1 to 2 millibars per hour than if bat activity were randomly distributed across the background pressure change classes that were recorded (Figure 15).

This same pattern is evident across the detector network (Figure 16). Approximately 72 percent of bat activity across the network was associated with little to no change $(-1$ to +1 millibars) in hourly barometric pressure. However, bat activity was greater than expected during negative hourly changes (-1 to 3 millibars) and is less than expected with neutral or positive hourly changes ( 1 to 2 millibars) than if it were randomly distributed across background pressure change classes (Figure 16).

\section{Precipitation \& Bat Activity}

Bat activity was distributed at random relative to background hours associated with and without precipitation (Figure 17). This may simply be a result of the facts that: (1) nighttime precipitation events in the Tendoy Mountains are rare with only 1 percent of nighttime hours associated with precipitation at the Harkness weather station; (2) the Harkness weather station is approximately 20.1 kilometers from the bat detector, and (3) precipitation was coded in hourly bins while bats are capable of flight within minutes after the passage of a storm front. Thus, bat activity recorded at the acoustic detector on Big Sheep Creek may be relatively meaningless with regard to precipitation events recorded at the Harkness weather station.

Across the acoustic detector network, bat activity was slightly more during hours with precipitation than would be expected if bat activity was randomly distributed between hours with and without precipitation (Figure 18). Again, because hourly precipitation events are rare, the weather stations were often somewhat distant from the acoustic detectors, and because precipitation was coded in hourly bins while bats are capable of flight within minutes after the passage of a storm front, patterns of bat activity relative to recorded precipitation events at weather stations may not be all that meaningful.

\section{Moonlight \& BAT ACTIVITY}

Patterns in the percent of hours with bat activity generally tracked patterns in the background percent of hours associated with various moon conditions (Figure 19). However, bat activity was much greater than would be expected during the full moon when it was above the horizon and at illumination levels of 0.8 to 1.0 when it was below the horizon than if bat activity had been randomly distributed across the various background moon illumination categories. The only other category with much greater bat activity than would be expected at random was the 0.1 illumination category when the moon was above the horizon (Figure 19). All other categories had bat activity levels as would be expected at random or below what would be expected at random.

Across the regional network of bat detectors, an opposite pattern in bat activity was evident with progressively greater bat activity than would be expected at random when moon illuminations were less than 0.5 and progressively less bat activity than would be expected at random when moon illuminations were greater than 0.5 (Figure 20). The importance of moon illumination to bat activity across the regional detector network is further 
demonstrated by the increase in the magnitude of increased bat activity relative to expected at illuminations less than 0.5 when the moon is below the horizon as compared to when it is above the horizon. Similarly, the decrease in the magnitude of the decreased bat activity relative to expected at illuminations greater than 0.5 when the moon is below the horizon as compared to when it is above the horizon, also strongly supports the consistent importance of moon illumination to overall bat activity across the regional detector network.

The Big Sheep Creek moon illumination results might, therefore, at first appear to be discordant with patterns across the region detector network. However, when one takes into account the fact that the Big Sheep Creek detector's microphone is mounted on a small cliff near the bottom of a canyon that would stay shaded from moon illumination unless the moon is directly overhead, it seems that the pattern observed at this detector is likely the exception that proves the rule that bats are shifting activity toward times or places that have lower illumination levels.

\section{Species Activity Patterns}

Identification of individual species activity patterns was hindered by relatively low and potentially inconsistent rates of autoidentification of call sequences to species (Table 4, Maxell 2015). Only Big Brown Bat, Silverhaired Bat, Western Small-footed Myotis, and Little Brown Myotis had relatively high rates of confirmation of monthly presence (Table 5) and enough calls auto-identified to examine trends. Call sequences of known species identity in the Montana Bat Call Library have also had relatively high accuracy rates ( $>50$ percent correct auto-identification rates) for these species. However, activity patterns for these species from auto-identified call sequences should still be regarded as speculative due to a variety of issues that might cause autoidentifications to be inaccurate and/or inconsistent (Maxell 2015).

Of the four species for which there is at least some justification for showing potential patterns of documented activity from autoidentified call sequences, there were three main patterns evident in average nightly passes per week (Figures 21 through 24). First, recorded activity for all these species was reduced in 2013 and 2014 relative to what it was in 2012, apparently as a result of the loss in sensitivity of the microphone. Second, in 2012, Big Brown Bat, Western Small-footed Myotis, and Little Brown Myotis all had reduced activity through early June with less than one pass per night on average, higher levels of activity through early September or October with one to up to twenty-three passes per night on average, and then reduced activity with less than one pass per night on average during the winter of 2012-2013. Third, in contrast to the other species, recorded Silver-haired Bat activity began relatively early, lasted relatively late into the year, and had no major peaks or troughs.

\section{Availability of Data Summaries}

The latest tabular and chart data summaries for bat activity patterns in association with time, weather, and other correlates for detectors across the regional network of ultrasonic acoustic monitoring stations are available by request from the Montana Natural Heritage Program through an Excel workbook. Pivot tables and charts in topical worksheets in this workbook can be filtered to produce the latest 
data summaries for one or more sites, time periods, and species.

As confirmations of individual species monthly presence and minimum temperatures of activity are made, this information is added to the animal point observation database at the
Montana Natural Heritage Program and is available to agency biologists and resource managers for regional and project-level planning online in the context of a variety of map information through the MapViewer web application http://mtnhp.org/mapviewer/ 


\section{Management Recommendations}

The above measures of overall bat activity near the detector, hand confirmed presence of individual species by month, and hand confirmed minimum temperatures associated with bat passes of individual species are all stable metrics upon which management recommendations can be made. However, patterns of activity of individual species resulting from automated analyses should be used with a great deal of caution due to low rates of species assignment and low or uncertain rates of accuracy of those assignments. Furthermore, it should be noted that bat activity measured during this study was made by a microphone on a 9-10 foot mast at the top of a small cliff and may not have adequately sampled the activity of high flying bats such as the Hoary Bat and Silver-haired Bat, which together with the Eastern Red Bat are the three species that have suffered approximately $75 \%$ of the documented mortalities associated with wind turbines across North America (Kunz et al. 2007). Thus, the following management recommendations avoid use of activity patterns of individual species as determined by automated analyses and instead rely on results of hand confirmed analyses, general patterns of bat activity that were recorded at the study site, and results of published studies of wind turbine impacts on bat species.

The following management recommendations are based on information gathered during this study, literature and documentation in Montana's animal point observation database on the roosting habits and habitats of
Montana's bat species (Appendix C, MTNHP 2016), compilations of literature on the impacts of wind turbines on bats (Table 1, Appendix A, see especially Schuster et al. 2015), and new voluntary best management practices adopted by the American Wind Energy Association (AWEA 2015).

Management recommendations include: (1) protecting potential natural roost sites by conserving large diameter trees (especially snags with loose bark), rock outcrops, cliff crevices, and caves (Appendix C); (2) maintaining accessibility for underground mine entrances that bats may be using as summer or winter roosts; (3) reducing structural complexity of vegetation (e.g., short stature grasslands) and availability of standing waters that might provide drinking opportunities for bats near wind turbines or other human structures that might represent a threat to bats or where bats are undesired; (4) if wind turbines are installed in the region, set turbine cut-in speeds to $\geq 6.0$ $\mathrm{m} / \mathrm{sec}$ between April and October - especially important in July during peak bat activity when young are newly flighted, and August, September, and October when migratory species are passing through and local bats are swarming and breeding; (5) feather wind turbine blades, or making them parallel to wind direction, when wind speeds are $<6 \mathrm{~m} / \mathrm{sec}$ so that they rotate at fewer than 1-3 revolutions per minute between April and October; and (6) install bat houses on warm south and west facing walls of human structures to provide summer roosting habitat while avoiding bat use of internal portions of the structures. 


\section{Literature Cited}

Agnarsson I, C.M. Zambrana-Torrelio, N.P. Flores-Saldana, and L.J. May-Collado. 2011. A time-calibrated species-level phylogeny of bats (Chiroptera, Mammalia). PLOS Currents Tree of Life. 2011 Feb 4. Edition 1. doi: 10.1371/currents.RRN1212.

Agranat, I. 2014. Detecting bats with ultrasonic microphones: understanding the effects of microphone variance and placement on detection rates. Unpublished white paper. Wildlife Acoustics, Maynard, MA. 14 p.

[AWEA] American Wind Energy Association. 2015. Wind energy industry announces new voluntary practices to reduce overall impacts on bats by 30 percent. American Wind Energy Association Press Release. September 3, 2015. Accessed at: http://www.awea.org/MediaCenter/pressrele ase.aspx?!temNumber $=7833$

Arnett, E.B., W.K. Brown, W.P. Erickson, J.K. Fiedler, B.L. Hamilton, T.H. Henry, A. Jain, G.D. Johnson, J. Kerns, R.R. Koford, C.P. Nicholson, T.J. O'Connell, M.D. Piorkowski, and R.D. Tankersley, Jr. 2008. Patterns of bat fatalities at wind energy facilities in North America. Journal of Wildlife Management 72(1):61-78.

Arnett, E.B., M.M.P. Huso, M.R. Schirmacher, and J.P. Hayes. 2011. Altering turbine speed reduces bat mortality at wind-energy facilities. Frontiers in Ecology and the Environment 9(4):209-214.

Baerwald, E.F., J. Edworthy, M. Holder, and R.M.R. Barclay. 2009. A large-scale mitigation experiment to reduce bat fatalities at wind energy facilities. Journal of Wildlife Management 73(7):1077-1081.

Barclay, R.M. and L.D. Harder. 2003. Life histories of bats: life in the slow lane. Pp. 209-256 In: T.H. Kunz and M.B. Fenton (eds.)
Bat Ecology. Chicago: University of Chicago Press. $779 \mathrm{p}$.

Bernard, R.F., J.T. Foster, E.V. Willcox, K.L. Parise, and G.F. McCracken. 2015. Molecular detection of the causative agent of Whitenose Syndrome on Rafinesque's big-eared bats (Corynorhinus rafinesquii) and two species of migratory bats in the southeastern USA. Journal of Wildlife Diseases 51(2):519522.

Blehert, D.S., A.C. Hicks, M. Behr, C.U. Meteyer, B.M. Berlowski-Zier, E.L. Buckles, J.T.H. Coleman, S.R. Darling, A. Gargas, R. Niver, J.C. Okoniewski, R.J. Rudd, and W.B. Stone. 2008. Bat white-nose syndrome: an emerging fungal pathogen? Science 323: 227. DOI:

10.1126/science. 1163874

Blehert, D.S., J.M. Lorch, A.E. Ballmann, P.M. Cryan, and C.U. Meteyer. 2011. Bat whitenose syndrome in North America. Microbe Magazine 6:267-273.

[COSEWIC] Committee on the Status of Endangered Wildlife in Canada. 3 February 2012. Emergency assessment concludes that three bat species are endangered in Canada. http://www.cosewic.gc.ca/eng/sct7/Bat_Eme rgency_Assessment_Press_Release_e.cfm

Cryan, P.M. 2008. Mating behavior as a possible cause of bat fatalities at wind turbines. Journal of Wildlife Management 72(3): 845-849.

Frank, C.L., A. Michalski, A.A. McDonough, M. Rahimian, R.J. Rudd, and C. Herzog. 2014. The resistance of a North American bat species (Eptesicus fuscus) to White-Nose Syndrome (WNS). Plos One 9:e113958.

DOI:10.1371/2Fjournal.pone.0113958. 
Frick W.F., J.F. Pollock, A.C. Hicks, K.E. Langwig, D.S. Reynolds, G.G. Turner, C.M. Butchkoski, and T.H. Kunz. 2010. An emerging disease causes regional population collapse of a common North American bat species. Science 329:679-682. DOI:10.1126/science.1188594.

Hayes, M. 2013. Bats killed in large numbers at United States wind energy facilities.

BioScience 63(12):975-979.

Heffernan, L. 2014. White-Nose Syndrome (WNS) occurrence by county/district. 3 September 2014. https://www.whitenosesyndrome.org/sites/d efault/files/resource/wns map 09-03-14.jpg

Johnson, G.D., M.K. Perlik, W.P. Erickson, and M.D. Strickland. 2004. Bat activity, composition, and collision mortality at large wind plant in Minnesota. Wildlife Society Bulletin 32(4):1278-1288.

Johnson J.S., D.M. Reeder DM, J.W. McMichael III, M.B. Meierhofer, D.W.F. Stern, S.S. Lumadue, L.E. Sigler, H.D. Winters, M.E. Vodzak, A. Kurta, J.A. Kath, and K.A. Field. 2014. Host, pathogen, and environmental characteristics predict white-nose syndrome mortality in captive little brown myotis (Myotis lucifugus). PLoS ONE 9(11): e112502. DOI:10.1371/journal.pone.0112502

Kunz, T.H., E.B. Arnett, W.P. Erickson, A.R. Hoar, G.D. Johnson, R.P. Larkin, M.D. Strickland, R.W. Thresher, and M.D. Tuttle. 2007. Ecological impacts of wind energy development on bats: questions, research needs, and hypotheses. Frontiers in Ecology and the Environment 5(6):315-324.

Kunz, T.H. and J.D. Reichard. 2010. Status review of the Little Brown Myotis (Myotis lucifugus) and determination that immediate listing under the Endangered Species Act is scientifically and legally warranted. $30 \mathrm{pp}$.
Langwig, K.E., W.F. Frick, J.T. Bried, A.C. Hicks, T.H. Kunz, and A.M. Kilpatrick. 2012. Ecology Letters 15:1050-1057. DOI: 10.1111/j.14610248.2012.01829.x

Langwig, K.E., W.F. Frick, R. Reynolds, K.L. Parise, K.P. Drees, J.R. Hoyt, T.L. Cheng, T.H. Kunz, J.T. Foster, and A.M. Kilpatrick. 2014. Host and pathogen ecology drive the seasonal dynamics of a fungal disease, white-nose syndrome. Proceedings Royal Society B 282: 20142335. DOI: 10.1098/rspb.2014.2335

Lausen, C.L. and R.M.R. Barclay. 2006. Winter bat activity in the Canadian prairies. Canadian Journal of Zoology 84:1079-1086.

Lorch J.M., C.U. Meteyer, M.J. Behr, J.G. Boyles, P.M. Cryan, A.C. Hicks, A.E. Ballmann, J.T.H. Coleman, D.N. Redell, D.M. Reeder, and D.S. Blehert. 2011. Experimental infection of bats with Geomyces destructans causes whitenose syndrome. Nature 480:376-378. DOI:10.1038/nature10590.

Maxell, B.A. Coordinator. 2015. Montana Bat and White-Nose Syndrome Surveillance Plan and Protocols 2012-2016. Montana Natural Heritage Program. Helena, MT. 185 p.

Minnis, A.M. and D.L. Lindner. 2013. Phylogenetic evaluation of Geomyces and allies reveals no close relatives of Pseudogymnoascus destructans, comb. nov., in hibernacula of eastern North America.

Fungal Biology 117(9):638-649.

[MTNHP] Montana Natural Heritage Program. 2016. Animal point observation database. Montana Natural Heritage Program. Helena, MT. Accessed January 2016.

Parsons, K.N., G. Jones, and F. Greenaway. 2003. Swarming activity of temperate zone microchiropteran bats: effects of season, time of night and weather conditions. Journal of Zoology 261:257-264. 
Parsons, S. and J.M. Szewczak. 2009.

Detecting, recording, and analyzing the vocalizations of bats. Pp. 91-111 In: Kunz, T.H. and S. Parsons. Ecological and behavioral methods for the study of bats. $2^{\text {nd }}$ edition. Johns Hopkins University Press. Baltimore, MD.

Poulton, V. and W. Erickson. 2010. Postconstruction bat and bird fatality study Judith Gap Wind Farm Wheatland County, Montana. Final Report. Results from June-October 2009 study and comparison with 2006-2007 study. Western Ecosystems Technology, Inc. 2003 Central Avenue, Cheyenne, WY. 35 p.

Schuster, E., L. Bulling, and J. Koppel. 2015. Consolidating the state of knowledge: a synoptical review of wind energy's wildlife effects. Environmental Management 56:300-331.

Smallwood, K.S. 2013. Comparing bird and bat fatality-rate estimates among North American wind-energy projects. Wildlife Society Bulletin 37(1):19-33.

U.S. Fish and Wildlife Service. 2012. North American bat death toll exceeds 5.5 million from white-nose syndrome. News Release.

U.S. Fish and Wildlife Service. 2014. Bats affected by WNS. Accessed 22 December 2014. https://www.whitenosesyndrome.org/about/ bats-affected-wns

U.S. Fish and Wildlife Service. 2015. Endangered and threatened wildlife and plants; threatened species status for the Northern Long-eared Bat with 4(d) rule; final rule and interim rule. Federal Register 80(63):17974-18033.

Warnecke L., J.M. Turner, T.K. Bollinger, J.M. Lorch, V. Misra, P.M. Cryan, G. Wibbelt, D.S. Blehert, and C.K.R. Willis. 2012. Inoculation of bats with European Geomyces destructans supports the novel pathogen hypothesis for the origin of white-nose syndrome.

Proceedings of the National Academy of Sciences 109:6999-7003.

DOI:10.1073/pnas.1200374109 
Table 1. Montana bat species, conservation status, and known or potential concerns from WNS and wind turbine facilities.

\begin{tabular}{|c|c|c|c|}
\hline Species & Conservation Status & $\begin{array}{l}\text { Species known to be affected by } \\
\text { White-Nose Syndrome I P. destructans }\end{array}$ & $\begin{array}{l}\text { Species known to be subject } \\
\text { to mortality at wind turbines }\end{array}$ \\
\hline $\begin{array}{c}\text { Pallid Bat } \\
\text { (Antrozous pallidus) }=\text { ANPA }\end{array}$ & $\begin{array}{l}\text { G5 S3, MT SOC, BLM } \\
\text { Sensitive, USFS Sensitive }\end{array}$ & No connection known at this time. & $\begin{array}{l}\text { No mortalities documented in } \\
\text { literature. }\end{array}$ \\
\hline $\begin{array}{c}\text { Townsend's Big-eared Bat } \\
\text { (Corynorhinus townsendii) }=\text { СОTO }\end{array}$ & $\begin{array}{l}\text { G34 S3, MT SOC, BLM } \\
\text { Sensitive, USFS Sensitive }\end{array}$ & $\begin{array}{l}\text { Detected, but no diagnostic sign of WNS (USFWS 2014). } \\
\text { Potential winter roost vector. }\end{array}$ & $\begin{array}{l}\text { No mortalities documented in } \\
\text { literature. }\end{array}$ \\
\hline $\begin{array}{c}\text { Big Brown Bat } \\
\text { (Eptesicus fuscus) = EPFU }\end{array}$ & G5 S4 & $\begin{array}{l}\text { Blehert et al. 2008, Langwig et al. 2012, 2014, Frank et al. } \\
2014 .\end{array}$ & $\begin{array}{l}\text { Johnson et al. 2004; Kunz et al. } \\
\text { 2007; Arnett et al. 2008, } 2011 .\end{array}$ \\
\hline $\begin{array}{c}\text { Spotted Bat } \\
(\text { Euderma maculatum })=\text { EUMA }\end{array}$ & $\begin{array}{l}\text { G4 S3, MT SOC, BLM } \\
\text { Sensitive, USFS Sensitive }\end{array}$ & No connection known at this time. & $\begin{array}{l}\text { No mortalities documented in } \\
\text { literature. }\end{array}$ \\
\hline $\begin{array}{c}\text { Silver-haired Bat } \\
\text { (Lasionycteris noctivagans) }=\text { LANO }\end{array}$ & G5 S4, Potential MT SOC & $\begin{array}{l}\text { Detected, but no diagnostic sign of WNS (Bernard et al. 2015, } \\
\text { USFWS 2014). Potential regional migratory vector. }\end{array}$ & $\begin{array}{l}\text { Johnson et al. 2004; Kunz et al. } \\
\text { 2007; Arnett et al. 2008, 2011; } \\
\text { Baerwald et al. 2009; Poulton } \\
\text { and Erickson 2010. }\end{array}$ \\
\hline $\begin{array}{c}\text { Eastern Red Bat } \\
\text { (Lasiurus borealis) }=\text { LABO }\end{array}$ & G5 SU, Potential MT PSOC & $\begin{array}{l}\text { Detected, but no diagnostic sign of WNS (Bernard et al. 2015, } \\
\text { USFWS 2014). Potential regional migratory vector. }\end{array}$ & $\begin{array}{l}\text { Kunz et al. 2007; Arnett et al. } \\
2008,2011 .\end{array}$ \\
\hline $\begin{array}{c}\text { Hoary Bat } \\
\text { (Lasiurus cinereus })=\mathrm{LACl}\end{array}$ & G5 S3, MT SOC & No connection known at this time. & $\begin{array}{l}\text { Johnson et al. 2004; Kunz et al. } \\
\text { 2007; Arnett et al. 2008, 2011; } \\
\text { Baerwald et al. 2009; Poulton } \\
\text { and Erickson 2010. }\end{array}$ \\
\hline $\begin{array}{c}\text { California Myotis } \\
\text { (Myotis californicus) }=\text { MYCA }\end{array}$ & G5 S4 & $\begin{array}{l}\text { Close relatedness to } M \text {. leibii indicates possible susceptibility } \\
\text { (Agnarsson et al. 2011, Langwig et al. 2012) }\end{array}$ & $\begin{array}{l}\text { No mortalities documented in } \\
\text { literature. }\end{array}$ \\
\hline $\begin{array}{l}\text { Western Small-footed Myotis } \\
\text { (Myotis ciliolabrum) }=\mathrm{MYCl}\end{array}$ & G5 S4 & $\begin{array}{l}\text { Relatively close relatedness to } M \text {. lucifugus indicates possible } \\
\text { susceptibility (Frick et al. 2010, Agnarsson et al. 2011) }\end{array}$ & $\begin{array}{l}\text { No mortalities documented in } \\
\text { literature. }\end{array}$ \\
\hline $\begin{array}{c}\text { Long-eared Myotis } \\
\text { (Myotis evotis) }=\text { MYEV }\end{array}$ & $\begin{array}{l}\text { G5 S4 } \\
\text { BLM Sensitive }\end{array}$ & $\begin{array}{l}\text { Close relatedness to M. sodalis indicates possible } \\
\text { susceptibility (Agnarsson et al. 2011, Langwig et al. 2012) }\end{array}$ & Kunz et al. 2007 \\
\hline $\begin{array}{c}\text { Little Brown Myotis } \\
\text { (Myotis lucifugus) }=\text { MYLU }\end{array}$ & G3 S3, MT SOC & $\begin{array}{l}\text { Blehert et al. 2008, Frick et al. 2010, Lorch et al. 2011, } \\
\text { Warnecke et al. 2012, Johnson et al. 2014, Langwig et al. } \\
\text { 2012, } 2014 .\end{array}$ & $\begin{array}{l}\text { Johnson et al. 2004; Kunz et al. } \\
\text { 2007; Arnett et al. 2008, } 2011 .\end{array}$ \\
\hline $\begin{array}{c}\text { Northern Myotis } \\
\text { (Myotis septentrionalis) }=\text { MYSE }\end{array}$ & $\begin{array}{l}\text { G1G3 SU, BLM Special } \\
\text { Status, USFS Threatened, } \\
\text { USFWS Listed Threatened }\end{array}$ & Blehert et al. 2008, Langwig et al. 2012, 2014, USFWS 2015. & $\begin{array}{l}\text { Kunz et al. 2007; Arnett et al. } \\
2008\end{array}$ \\
\hline $\begin{array}{c}\text { Fringed Myotis } \\
\text { (Myotis thysanodes) }=\text { MYTH }\end{array}$ & $\begin{array}{l}\text { G4 S3, MT SOC, BLM } \\
\text { Sensitive }\end{array}$ & $\begin{array}{l}\text { Relatively close relatedness to M. lucifugus indicates possible } \\
\text { susceptibility (Frick et al. 2010, Agnarsson et al. 2011) }\end{array}$ & $\begin{array}{l}\text { No mortalities documented in } \\
\text { literature. }\end{array}$ \\
\hline $\begin{array}{c}\text { Long-legged Myotis } \\
\text { (Myotis volans) }=\text { MYVO }\end{array}$ & $\begin{array}{l}\text { G5 S4 } \\
\text { BLM Sensitive }\end{array}$ & $\begin{array}{l}\text { Close relatedness to M. sodalis indicates possible } \\
\text { susceptibility (Agnarsson et al. 2011, Langwig et al. 2012) }\end{array}$ & $\begin{array}{l}\text { No mortalities documented in } \\
\text { literature. }\end{array}$ \\
\hline $\begin{array}{c}\text { Yuma Myotis } \\
\text { (Myotis yumanensis) }=\text { MYYU }\end{array}$ & $\begin{array}{l}\text { G5 S3S4, Potential MT } \\
\text { SOC }\end{array}$ & $\begin{array}{l}\text { Relatively close relatedness to M. grisescens indicates } \\
\text { possible susceptibility (Agnarsson et al. 2011, USFWS 2014) }\end{array}$ & $\begin{array}{l}\text { No mortalities documented in } \\
\text { literature. }\end{array}$ \\
\hline
\end{tabular}

*Unidentified Myotis species mortalities have also been reported at the Judith Gap Wind Farm (Poulton and Erickson 2010). 
Table 2. Bat species present or potentially present in the Tendoy Mountains prior to and during this study.

\begin{tabular}{|c|c|c|c|}
\hline Species & $\begin{array}{c}\text { Previous Documentation During } \\
\text { Active Season }{ }^{1}\end{array}$ & $\begin{array}{l}\text { Documented Periods of } \\
\text { Activity During this Study }\end{array}$ & $\begin{array}{c}\text { Documented or Potential Use of } \\
\text { Hibernacula in Region }\end{array}$ \\
\hline $\begin{array}{l}\text { Townsend's Big-eared Bat } \\
\text { (Corynorhinus townsendii) }^{2}\end{array}$ & Not documented. Potential. & Possible $^{2}$ & Not documented. Potential. \\
\hline $\begin{array}{c}\text { Big Brown Bat } \\
\text { (Eptesicus fuscus) }\end{array}$ & $\begin{array}{l}5 \text { acoustic and } 3 \text { mist net records } \\
\text { in June and August }\end{array}$ & June through October & Not documented. Potential. \\
\hline $\begin{array}{c}\text { Silver-haired Bat } \\
\text { (Lasionycteris noctivagans) }\end{array}$ & $\begin{array}{l}12 \text { acoustic records in June, July, } \\
\text { August, and September }\end{array}$ & March through November & $\begin{array}{l}\text { Believed until recently to be migratory, } \\
\text { but acoustic evidence counters this. }\end{array}$ \\
\hline $\begin{array}{c}\text { Hoary Bat } \\
\text { (Lasiurus cinereus) }\end{array}$ & $\begin{array}{l}7 \text { acoustic and } 1 \text { mist net record } \\
\text { in June, July, and August }\end{array}$ & July through September & Migratory \\
\hline $\begin{array}{c}\text { California Myotis } \\
{\text { (Myotis californicus })^{3}}\end{array}$ & 1 acoustic record in August & Not confirmed $^{3}$ & Not documented. Potential. \\
\hline $\begin{array}{l}\text { Western Small-footed Myotis } \\
\text { (Myotis ciliolabrum) }\end{array}$ & $\begin{array}{l}10 \text { acoustic and } 1 \text { mist net records } \\
\text { in June, July, and August }\end{array}$ & March through September & Not documented. Potential. \\
\hline $\begin{array}{l}\text { Long-eared Myotis } \\
\text { (Myotis evotis) }\end{array}$ & $\begin{array}{l}9 \text { acoustic and } 3 \text { mist net records } \\
\text { in June, July, and August }\end{array}$ & May through October & Not documented. Potential. \\
\hline $\begin{array}{l}\text { Little Brown Myotis } \\
\text { (Myotis lucifugus) }\end{array}$ & $\begin{array}{l}19 \text { acoustic and } 5 \text { mist net records } \\
\text { in June, July, and August }\end{array}$ & April through October & Not documented. Potential. \\
\hline 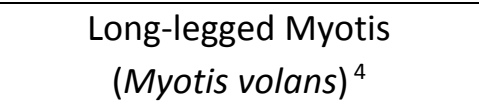 & $\begin{array}{l}1 \text { acoustic and } 1 \text { mist net record } \\
\text { in June and August }\end{array}$ & Not confirmed $^{4}$ & Not documented. Potential. \\
\hline $\begin{array}{c}\text { Yuma Myotis } \\
\text { (Myotis yumanensis) }^{5}\end{array}$ & Not documented. Potential. & Possible $^{5}$ & Not documented. Potential. \\
\hline
\end{tabular}

1 Records between April 1 and October 31 in the point observation database at the Montana Natural Heritage Program dating prior to 2012.

2 Species is relatively quiet and often does not create fully definitive echolocation call recordings on bat detectors.

3 Several call sequences were auto-identified as California Myotis. However, these call sequences lacked the definitive characteristics necessary to confirm the species presence. The species presence in the region is currently based on a single call sequence recorded in 2006. Mist net capture and morphological verification is needed.

4 Several call sequences were auto-identified as Long-legged Myotis. However, these call sequences lacked the definitive characteristics necessary to confirm the species presence.

5 We classified two call sequences that were auto-identified as Yuma Myotis as probable and two other sequences meet all the definitive characteristics of Yuma Myotis. However, because this region is outside the range where the species has been documented with mist net captures, we plan to regard all of these sequences as potentially Yuma Myotis until there is genetic confirmation of the species in the region. 
Table 3. Deployment history of SM2 Bat+ detector/recorder on Big Sheep Creek.

\begin{tabular}{|c|c|}
\hline Service Date & Comments \\
\hline $1 / 31 / 2012$ & $\begin{array}{l}\text { Deployed detector in Big Sheep Creek drainage with microphone just above the creek at Latitude }=44.61183 \text { and Longitude }= \\
-112.80327 \text { and detector/recorder and solar panel/battery at Latitude }=44.612056 \text { and Longitude }=-112.80361\end{array}$ \\
\hline $2 / 21 / 2012$ & Detector/recorder and microphones were checked and data were downloaded. \\
\hline $3 / 5 / 2012$ & Detector/recorder and microphones were checked and data were downloaded. \\
\hline $3 / 12 / 2012$ & Detector/recorder and microphones were checked and data were downloaded. \\
\hline $5 / 10 / 2012$ & $\begin{array}{l}\text { Detector/recorder and microphones were checked and data were downloaded. Temperature data from } 11 \text { April and } 9 \text { May } \\
\text { was accidentally discarded. }\end{array}$ \\
\hline $6 / 25 / 2012$ & Detector/recorder and microphones were checked and data were downloaded. \\
\hline $7 / 18 / 2012$ & Detector/recorder and microphones were checked and data were downloaded. \\
\hline $9 / 20 / 2012$ & Detector/recorder and microphones were checked and data were downloaded. \\
\hline $10 / 23 / 2012$ & Detector/recorder and microphones were checked and data were downloaded. \\
\hline $11 / 21 / 2012$ & Detector/recorder and microphones were checked and data were downloaded. \\
\hline $2 / 12 / 2013$ & Detector/recorder and microphones were checked and data were downloaded. \\
\hline $6 / 12 / 2013$ & $\begin{array}{l}\text { Detector/recorder and microphones were checked and data were downloaded. Microphone had lost sensitivity relative to } \\
2012 \text { and was operating at reduced sensitivity after this point. }\end{array}$ \\
\hline 9/6/2013 & Detector/recorder and microphones were checked and data were downloaded. Microphone had reduced sensitivity. \\
\hline $3 / 13 / 2014$ & Detector/recorder and microphones were checked and data were downloaded. Microphone had reduced sensitivity. \\
\hline $6 / 23 / 2014$ & Detector/recorder and microphones were checked and data were downloaded. Microphone had reduced sensitivity. \\
\hline $7 / 11 / 2014$ & $\begin{array}{l}\text { Detector/recorder and microphones were checked. Temperature and acoustic data was not gathered between } 26 \text { June and } 10 \\
\text { July due to the theft of the solar panel and loss of charge in the battery. A fully charged battery was reinstalled on this service } \\
\text { date, but the solar panel was not replaced. Microphone had reduced sensitivity. }\end{array}$ \\
\hline $8 / 14 / 2014$ & Detector/recorder and microphones were checked and data were downloaded. Microphone had reduced sensitivity. \\
\hline $10 / 6 / 2014$ & $\begin{array}{l}\text { The battery was swapped out on this date. Battery power had fallen below the threshold for powering the detector on } 15 \\
\text { August and no temperature or acoustic data was gathered between then and } 5 \text { October. Microphone had reduced sensitivity. }\end{array}$ \\
\hline $1 / 6 / 2015$ & $\begin{array}{l}\text { The entire detector/recorder system was decommissioned on this service date. The microphone had greatly reduced } \\
\text { sensitivity and only } 3 \text { call sequences were recorded in October before the battery died on } 25 \text { October, } 2014 \text { which effectively } \\
\text { ended the study. }\end{array}$ \\
\hline
\end{tabular}


Table 4. Detector status as measured by percent of calls auto-identified to species

\begin{tabular}{|c|c|c|c|c|}
\hline Year & Month & $\begin{array}{c}\text { Total No. } \\
\text { of Calls } \\
\end{array}$ & $\begin{array}{l}\text { No. Calls Classified } \\
\text { to Species }\end{array}$ & $\begin{array}{c}\% \text { Auto-identified } \\
\text { to Species }\end{array}$ \\
\hline 2012 & February & 2 & 1 & $50.0 \%$ \\
\hline 2012 & March & 31 & 13 & $41.9 \%$ \\
\hline 2012 & April & 217 & 33 & $15.2 \%$ \\
\hline 2012 & May & 582 & 58 & $10.0 \%$ \\
\hline 2012 & June & 1382 & 230 & $16.6 \%$ \\
\hline 2012 & July & 1745 & 382 & $21.9 \%$ \\
\hline 2012 & August & 2027 & 463 & $22.8 \%$ \\
\hline 2012 & September & 1845 & 161 & $8.7 \%$ \\
\hline 2012 & October & 832 & 107 & $12.9 \%$ \\
\hline 2012 & November & 15 & 7 & $46.7 \%$ \\
\hline 2012 & December & 1 & 0 & $0.0 \%$ \\
\hline 2013 & January & 0 & - & - \\
\hline 2013 & February & 0 & - & - \\
\hline 2013 & March & 23 & 13 & $56.5 \%$ \\
\hline 2013 & April & 102 & 21 & $20.6 \%$ \\
\hline 2013 & May & 97 & 16 & $16.5 \%$ \\
\hline 2013 & June $^{1}$ & 76 & 0 & $0.0 \%$ \\
\hline 2013 & July & 335 & 10 & $3.0 \%$ \\
\hline 2013 & August & 449 & 30 & $6.7 \%$ \\
\hline 2013 & September & 723 & 82 & $11.3 \%$ \\
\hline 2013 & October & 896 & 87 & $9.7 \%$ \\
\hline 2013 & November & 3 & 1 & $33.3 \%$ \\
\hline 2013 & December & 0 & - & - \\
\hline 2014 & January & 0 & - & - \\
\hline 2014 & February & 0 & - & - \\
\hline 2014 & March & 0 & - & - \\
\hline 2014 & April & 47 & 0 & $0.0 \%$ \\
\hline 2014 & May & 60 & 3 & $5.0 \%$ \\
\hline 2014 & June $^{2}$ & 176 & 4 & $2.3 \%$ \\
\hline 2014 & July ${ }^{2}$ & 453 & 40 & $8.8 \%$ \\
\hline 2014 & August $^{2}$ & 147 & 14 & $9.5 \%$ \\
\hline 2014 & September $^{2}$ & 0 & - & - \\
\hline \multirow[t]{2}{*}{2014} & October $^{2}$ & 3 & 0 & $0.0 \%$ \\
\hline & & $\Sigma=12,269$ & $\Sigma=1,776$ & $X=14.5 \%$ \\
\hline
\end{tabular}

${ }^{1}$ Microphone had lost sensitivity after May of 2013.

2 There were power/charging malfunctions during these time periods as a result of the theft of the solar panel in June of 2014. See comments in Table 3. 
Table 5. Monthly rates of hand confirmation from automated analysis results

\begin{tabular}{|c|c|c|c|}
\hline Species & $\begin{array}{l}\text { No. months with } \\
\text { automated } \\
\text { identification of } \\
\text { species }\end{array}$ & $\begin{array}{l}\text { No. months with } \\
\text { hand confirmed } \\
\text { identification of } \\
\text { species }\end{array}$ & $\begin{array}{l}\text { Percent of months } \\
\text { automated } \\
\text { identification was } \\
\text { hand confirmed }\end{array}$ \\
\hline $\begin{array}{l}\text { Townsend's Big-eared Bat } \\
\text { (Corynorhinus townsendii) }^{1}\end{array}$ & 7 & 0 & $0.0 \%$ \\
\hline $\begin{array}{l}\text { Big Brown Bat } \\
\text { (Eptesicus fuscus) }\end{array}$ & 16 & 7 & $43.8 \%$ \\
\hline $\begin{array}{l}\text { Silver-haired Bat } \\
\text { (Lasionycterus noctivagans) }\end{array}$ & 16 & 15 & $93.8 \%$ \\
\hline $\begin{array}{l}\text { Hoary Bat } \\
\text { (Lasiurus cinereus) }\end{array}$ & 4 & 4 & $100.0 \%$ \\
\hline $\begin{array}{l}\text { California Myotis } \\
\text { (Myotis californicus) }^{2}\end{array}$ & 6 & 0 & $0.0 \%$ \\
\hline $\begin{array}{l}\text { Western Small-footed Myotis } \\
\text { (Myotis ciliolabrum) }\end{array}$ & 18 & 14 & $77.8 \%$ \\
\hline $\begin{array}{l}\text { Long-eared Myotis } \\
\text { (Myotis evotis) }\end{array}$ & 7 & 7 & $100.0 \%$ \\
\hline $\begin{array}{l}\text { Little Brown Myotis } \\
\text { (Myotis lucifugus) }\end{array}$ & 16 & 15 & $93.8 \%$ \\
\hline $\begin{array}{l}\text { Long-legged Myotis } \\
\text { (Myotis volans) }^{3}\end{array}$ & 8 & 0 & $0.0 \%$ \\
\hline $\begin{array}{l}\text { Yuma Myotis } \\
\text { (Myotis yumanensis) }^{4}\end{array}$ & 9 & 0 & $0.0 \%$ \\
\hline
\end{tabular}

1 Species is relatively quiet and often does not create fully definitive echolocation call recordings on bat detectors.

2 California Myotis calls can overlap with Western Small-footed Myotis, Yuma Myotis, and Little Brown Myotis calls (Maxell 2015). Several call sequences were auto-identified as California Myotis. However, these call sequences lacked the definitive characteristics necessary to confirm the species presence. The species presence in the region is currently based on a single call sequence recorded in 2006. Mist net capture and morphological verification is needed.

3 Long-legged Myotis calls can overlap with Western Small-footed Myotis, Long-eared Myotis, Little Brown Myotis, and Fringed Myotis calls and rarely have call characteristics recorded that allow them to be definitively identified as Long-legged Myotis (Maxell 2015). Several call sequences were auto-identified as Long-legged Myotis. However, these call sequences lacked the definitive characteristics necessary to confirm the species presence.

4 Yuma Myotis calls can overlap with Little Brown Myotis and California Myotis calls (Maxell 2015). We classified two call sequences that were auto-identified as Yuma Myotis as probable and two other sequences meet all the definitive characteristics of Yuma Myotis. However, because this region is outside the range where the species has been documented with mist net captures, we plan to regard all of these sequences as potentially Yuma Myotis until there is genetic confirmation of the species in the region. 
Table 6. Species definitively detected by month each year of the study $y^{1,2}$

\begin{tabular}{|c|c|c|c|c|c|c|c|c|c|c|c|c|}
\hline Species & Jan & Feb & March & April & May & June & July & Aug & Sept & Oct & Nov & Dec \\
\hline $\begin{array}{c}\text { Big Brown Bat } \\
\text { (Eptesicus fuscus) }\end{array}$ & & & & & & $\begin{array}{l}2012 \\
2014\end{array}$ & 2012 & $\begin{array}{l}2012 \\
2013\end{array}$ & 2012 & $\begin{array}{l}2012 \\
2013\end{array}$ & & \\
\hline $\begin{array}{c}\text { Silver-haired Bat } \\
\text { (Lasionycteris noctivagans) }\end{array}$ & & & 2012 & $\begin{array}{l}2012 \\
2013\end{array}$ & $\begin{array}{l}2012 \\
2014\end{array}$ & 2012 & $\begin{array}{l}2012 \\
2014\end{array}$ & $\begin{array}{l}2012 \\
2014\end{array}$ & $\begin{array}{l}2012 \\
2013\end{array}$ & $\begin{array}{l}2012 \\
2013\end{array}$ & 2012 & \\
\hline $\begin{array}{c}\text { Hoary Bat } \\
\text { (Lasiurus cinereus) }\end{array}$ & & & & & & & $\begin{array}{l}2012 \\
2014\end{array}$ & $\begin{array}{l}2012 \\
2013 \\
2014\end{array}$ & $\begin{array}{l}2012 \\
2013\end{array}$ & & & \\
\hline $\begin{array}{l}\text { California Myotis } \\
\text { (Myotis californicus) }^{3}\end{array}$ & & & & & & & & & & & & \\
\hline $\begin{array}{l}\text { Western Small-footed Myotis } \\
\text { (Myotis ciliolabrum) }\end{array}$ & & & 2013 & 2013 & $\begin{array}{l}2012 \\
2013 \\
2014 \\
\end{array}$ & 2012 & $\begin{array}{l}2012 \\
2013 \\
2014 \\
\end{array}$ & $\begin{array}{l}2012 \\
2013 \\
2014 \\
\end{array}$ & $\begin{array}{l}2012 \\
2013\end{array}$ & & & \\
\hline $\begin{array}{l}\text { Long-eared Myotis } \\
\text { (Myotis evotis) }\end{array}$ & & & & & $\begin{array}{l}2012 \\
2013 \\
2014\end{array}$ & $\begin{array}{l}2012 \\
2013 \\
2014\end{array}$ & $\begin{array}{l}2012 \\
2013 \\
2014\end{array}$ & $\begin{array}{l}2012 \\
2013 \\
2014\end{array}$ & 2012 & 2012 & & \\
\hline $\begin{array}{l}\text { Little Brown Myotis } \\
\text { (Myotis lucifugus) }\end{array}$ & & & & $\begin{array}{l}2012 \\
2013\end{array}$ & $\begin{array}{l}2012 \\
2013\end{array}$ & 2012 & $\begin{array}{l}2013 \\
2014\end{array}$ & $\begin{array}{l}2012 \\
2013 \\
2014\end{array}$ & $\begin{array}{l}2012 \\
2013\end{array}$ & $\begin{array}{l}2012 \\
2013\end{array}$ & & \\
\hline 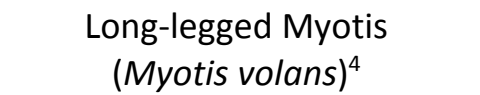 & & & & & & & & & & & & \\
\hline
\end{tabular}

Blue cells of table indicate documentation of the species in the region during this month prior to this study

2 See comments in Table 3 on periods of time when there were detector/recorder, microphone, or power system malfunctions.

${ }^{3}$ California Myotis calls can overlap with Western Small-footed Myotis, Yuma Myotis, and Little Brown Myotis calls (Maxell 2015). Several call sequences were autoidentified as California Myotis. However, these call sequences lacked the definitive characteristics necessary to confirm the species presence. The species presence in the region is currently based on a single call sequence recorded in 2006. Mist net capture and morphological verification is needed.

${ }^{4}$ Long-legged Myotis calls can overlap with Western Small-footed Myotis, Long-eared Myotis, Little Brown Myotis, and Fringed Myotis calls and rarely have call characteristics recorded that allow them to be definitively identified as Long-legged Myotis (Maxell 2015). Several call sequences were auto-identified as Long-legged Myotis. However, these call sequences lacked the definitive characteristics necessary to confirm the species presence. 
Table 7. Species definitively detected by month across the acoustic detector network (blue cells) and at the Big Sheep Creek detector (X)

\begin{tabular}{|c|c|c|c|c|c|c|c|c|c|c|c|c|}
\hline Species & Jan & Feb & March & April & May & June & July & Aug & Sept & Oct & Nov & Dec \\
\hline $\begin{array}{c}\text { Big Brown Bat } \\
\text { (Eptesicus fuscus) }\end{array}$ & & & & & & $x$ & $x$ & $x$ & $x$ & $x$ & & \\
\hline $\begin{array}{c}\text { Silver-haired Bat } \\
\text { (Lasionycteris noctivagans) }\end{array}$ & & & $x$ & $x$ & $x$ & $x$ & $x$ & $x$ & $x$ & $x$ & $x$ & \\
\hline $\begin{array}{c}\text { Hoary Bat } \\
\text { (Lasiurus cinereus) } \\
\end{array}$ & & & & & & & $x$ & $x$ & $x$ & & & \\
\hline \multicolumn{13}{|l|}{$\begin{array}{c}\text { California Myotis } \\
{\text { (Myotis californicus })^{1}}\end{array}$} \\
\hline $\begin{array}{l}\text { Western Small-footed Myotis } \\
\text { (Myotis ciliolabrum) }\end{array}$ & & & $x$ & $x$ & $x$ & $x$ & $x$ & $x$ & $x$ & & & \\
\hline $\begin{array}{l}\text { Long-eared Myotis } \\
\text { (Myotis evotis) }\end{array}$ & & & & & $x$ & $x$ & $x$ & $x$ & $x$ & $x$ & & \\
\hline $\begin{array}{l}\text { Little Brown Myotis } \\
\text { (Myotis lucifugus) }\end{array}$ & & & & $x$ & $x$ & $X$ & $x$ & $x$ & $x$ & $x$ & & \\
\hline $\begin{array}{l}\text { Long-legged Myotis } \\
\text { (Myotis volans) }^{2}\end{array}$ & & & & & & & & & & & & \\
\hline
\end{tabular}

${ }^{1}$ California Myotis calls can overlap with Western Small-footed Myotis, Yuma Myotis, and Little Brown Myotis calls (Maxell 2015). Several call sequences were autoidentified as California Myotis. However, these call sequences lacked the definitive characteristics necessary to confirm the species presence. The species presence in the region is currently based on a single call sequence recorded in 2006. Mist net capture and morphological verification is needed.

${ }^{2}$ Long-legged Myotis calls can overlap with Western Small-footed Myotis, Long-eared Myotis, Little Brown Myotis, and Fringed Myotis calls and rarely have call

characteristics recorded that allow them to be definitively identified as Long-legged Myotis (Maxell 2015). Several call sequences were auto-identified as Long-legged Myotis. However, these call sequences lacked the definitive characteristics necessary to confirm the species presence. 
Table 8. Bat passes summarized by month across all species

\begin{tabular}{|c|c|c|c|c|c|c|c|}
\hline Year & Month & $\begin{array}{c}\text { Total } \\
\text { no. bat } \\
\text { passes }\end{array}$ & $\begin{array}{c}\text { No. } \\
\text { sample } \\
\text { nights }^{1}\end{array}$ & $\begin{array}{l}\text { Avg no. } \\
\text { of nightly } \\
\text { passes }\end{array}$ & $\begin{array}{c}\text { StDev of } \\
\text { nightly } \\
\text { passes }\end{array}$ & $\begin{array}{l}\text { Min count of } \\
\text { nightly bat } \\
\text { passes }\end{array}$ & $\begin{array}{c}\text { Max count of } \\
\text { nightly bat } \\
\text { passes }\end{array}$ \\
\hline 2012 & 1 & 0 & 1 & 0 & & 0 & 0 \\
\hline 2012 & 2 & 2 & 29 & 0.1 & 0.3 & 0 & 1 \\
\hline 2012 & 3 & 31 & 31 & 1 & 2 & 0 & 6 \\
\hline 2012 & 4 & 211 & 30 & 7.2 & 12.4 & 0 & 62 \\
\hline 2012 & 5 & 567 & 31 & 18.8 & 28.9 & 0 & 117 \\
\hline 2012 & 6 & 1382 & 30 & 46.1 & 54.9 & 0 & 212 \\
\hline 2012 & 7 & 1745 & 31 & 56.3 & 58 & 4 & 320 \\
\hline 2012 & 8 & 2027 & 31 & 65.4 & 46.6 & 15 & 201 \\
\hline 2012 & 9 & 1845 & 30 & 61.5 & 75.3 & 2 & 284 \\
\hline 2012 & 10 & 832 & 31 & 26.8 & 52 & 0 & 204 \\
\hline 2012 & 11 & 15 & 30 & 0.5 & 1.4 & 0 & 6 \\
\hline 2012 & 12 & 1 & 31 & 0 & 0.2 & 0 & 1 \\
\hline 2013 & 1 & 0 & 31 & 0 & 0 & 0 & 0 \\
\hline 2013 & 2 & 0 & 28 & 0 & 0 & 0 & 0 \\
\hline 2013 & 3 & 23 & 31 & 0.7 & 2.9 & 0 & 16 \\
\hline 2013 & 4 & 102 & 30 & 3.4 & 5.4 & 0 & 23 \\
\hline 2013 & 5 & 97 & 31 & 3.1 & 4.8 & 0 & 22 \\
\hline 2013 & 6 & 76 & 30 & 2.5 & 3.3 & 0 & 15 \\
\hline 2013 & 7 & 335 & 31 & 10.8 & 15.1 & 0 & 74 \\
\hline 2013 & 8 & 449 & 31 & 14.5 & 12.8 & 1 & 58 \\
\hline 2013 & 9 & 723 & 30 & 24.1 & 34.1 & 0 & 118 \\
\hline 2013 & 10 & 896 & 31 & 28.9 & 63.5 & 0 & 322 \\
\hline 2013 & 11 & 3 & 30 & 0.1 & 0.5 & 0 & 3 \\
\hline 2013 & 12 & 0 & 31 & 0 & 0 & 0 & 0 \\
\hline 2014 & 1 & 0 & 31 & 0 & 0 & 0 & 0 \\
\hline 2014 & 2 & 0 & 28 & 0 & 0 & 0 & 0 \\
\hline 2014 & 3 & 0 & 31 & 0 & 0 & 0 & 0 \\
\hline 2014 & 4 & 47 & 30 & 1.6 & 2.7 & 0 & 13 \\
\hline 2014 & 5 & 60 & 31 & 1.9 & 2.5 & 0 & 12 \\
\hline 2014 & 6 & 176 & 25 & 7 & 9.2 & 0 & 32 \\
\hline 2014 & 7 & 453 & 21 & 21.6 & 15.1 & 2 & 52 \\
\hline 2014 & 8 & 147 & 13 & 11.3 & 10.2 & 4 & 43 \\
\hline 2014 & 9 & - & 0 & - & - & - & - \\
\hline 2014 & 10 & 3 & 19 & 0.2 & 0.5 & 0 & 2 \\
\hline
\end{tabular}

${ }^{1}$ Number of nights the detector/recorder was powered and logging temperatures and capable of recording bat passes. See Table 3 for periods of time when microphones had lost sensitivity or the detector recorder had power issues and may not have been functioning properly. There were large time periods between 26 June and 25 October of 2014 when the detector/recorder was not properly powered. 
Table 9. Nightly background and bat pass temperatures summarized by month ${ }^{1}$

\begin{tabular}{|c|c|c|c|c|c|c|c|}
\hline 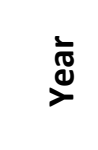 & 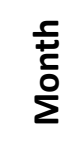 & $\begin{array}{l}\text { Background } \\
\text { Temp C } \\
\text { Avg (SD) N }\end{array}$ & $\begin{array}{c}\text { Bat Pass } \\
\text { Temp C } \\
\text { Avg (SD) N }\end{array}$ & $\begin{array}{c}\text { Background } \\
\text { Min } \\
\text { Temp C }\end{array}$ & $\begin{array}{l}\text { Bat Pass } \\
\text { Min } \\
\text { Temp C }\end{array}$ & $\begin{array}{c}\text { Background } \\
\text { Max } \\
\text { Temp C }\end{array}$ & $\begin{array}{c}\text { Bat Pass } \\
\text { Max } \\
\text { Temp C }\end{array}$ \\
\hline 2012 & 1 & $-6.0(3.2) 98$ & 3 & -11.2 & 3 & -1.5 & 3 \\
\hline 2012 & 2 & $-4.6(5.1) 8462$ & $3.3(3.7) 2$ & -20.5 & 0.6 & 6.7 & 5.9 \\
\hline 2012 & 3 & $1.2(5.2) 10516$ & $9(2.2) 31$ & -20.5 & 3.7 & 12.2 & 11.8 \\
\hline 2012 & 4 & $0(3.2) 5052$ & $6.4(2.2) 28$ & -13.2 & -0.1 & 11.8 & 11.7 \\
\hline 2012 & 5 & $6.4(5.2) 2329$ & $14.8(4.1) 473$ & -4.1 & 2.4 & 20.3 & 20.3 \\
\hline 2012 & 6 & 9.5 (5.5) 3092 & 16.5 (4.4) 1382 & -1.6 & 2.7 & 23.7 & 23.7 \\
\hline 2012 & 7 & $14.7(4.2) 3323$ & 17.8 (3.3) 1745 & 1.6 & 3.1 & 25.1 & 24.9 \\
\hline 2012 & 8 & $13.5(4.8) 3752$ & 17.2 (3.7) 2027 & 0.1 & 6.7 & 26.7 & 26.5 \\
\hline 2012 & 9 & $9.1(5.2) 4176$ & 16.5 (2.1) 1845 & -2.8 & 4.2 & 21.9 & 21.9 \\
\hline 2012 & 10 & 1 (5.7) 6491 & 14.3 (2.9) 832 & -13.9 & 4.4 & 17.4 & 17.4 \\
\hline 2012 & 11 & $-2.1(6.1) 16440$ & $8.5(2.1) 15$ & -20.5 & 4.7 & 11.5 & 11.3 \\
\hline 2012 & 12 & -5.5 (5.7) 19968 & $5.2\left(^{4}\right) 1$ & -20.5 & 5.2 & 7.2 & 5.2 \\
\hline 2013 & 1 & -10 (5.4) 12255 & 3 & -20.5 & 3 & 3.1 & 3 \\
\hline 2013 & 2 & -4.7 (3.9) 9300 & 3 & -20.5 & 3 & 3.4 & 3 \\
\hline 2013 & 3 & $-1.9(4.8) 4509$ & $6.5(1.4) 23$ & -14.2 & 3.9 & 9.4 & 8 \\
\hline 2013 & 4 & $0.7(4.7) 3808$ & $8.8(3.2) 102$ & -11.4 & 2.9 & 14.5 & 14.5 \\
\hline 2013 & 5 & $6.6(4.2) 3421$ & 13.3 (3.9) 97 & -8.2 & 6.7 & 20.4 & 20.4 \\
\hline 2013 & 6 & $10.2(5.1) 3078$ & $15.8(4.1) 76$ & -0.6 & 7.7 & 22.9 & 22.7 \\
\hline 2013 & 7 & 14.5 (4) 3314 & $19.4(3) 335$ & 6.4 & 8.2 & 24.7 & 24.7 \\
\hline 2013 & 8 & $13.9(4.3) 3746$ & 16.9 (3.8) 449 & 5.9 & 7.2 & 25.7 & 25.2 \\
\hline 2013 & 9 & 10.5 (5) 4166 & $14.9(4.4) 723$ & -0.6 & 4.4 & 22.1 & 21.7 \\
\hline 2013 & 10 & $1.6(4.1) 4875$ & $10.7(2.3) 896$ & -7.7 & 1.4 & 13.5 & 13.5 \\
\hline 2013 & 11 & $-2.1(5.3) 5207$ & $3(1) 3$ & -16.2 & 2.4 & 9.5 & 4.1 \\
\hline 2013 & 12 & $-7.8(8) 5637$ & 3 & -20.5 & 3 & 8.2 & 3 \\
\hline 2014 & 1 & $-4.8(4.8) 5490$ & 3 & -17.3 & 3 & 4.6 & 3 \\
\hline 2014 & 2 & $-5.5(7.4) 4592$ & 3 & -20.5 & 3 & 7 & 3 \\
\hline 2014 & 3 & $-0.5(5.3) 4527$ & 3 & -15 & 3 & 10.2 & 3 \\
\hline 2014 & 4 & $2.1(4.4) 3823$ & $7.2(2.8) 47$ & -10.7 & 0.1 & 14.1 & 13.5 \\
\hline
\end{tabular}


Table 9. Continued.

\begin{tabular}{|c|c|c|c|c|c|c|c|}
\hline 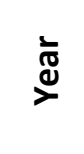 & 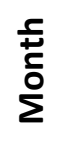 & $\begin{array}{l}\text { Background } \\
\text { Temp C } \\
\text { Avg (SD) N }\end{array}$ & $\begin{array}{c}\text { Bat Pass Temp } \\
\text { C } \\
\text { Avg (SD) N }\end{array}$ & $\begin{array}{c}\text { Background } \\
\text { Min } \\
\text { Temp C }\end{array}$ & $\begin{array}{l}\text { Bat Pass } \\
\text { Min } \\
\text { Temp C }\end{array}$ & $\begin{array}{c}\text { Background } \\
\text { Max } \\
\text { Temp C }\end{array}$ & $\begin{array}{c}\text { Bat Pass } \\
\text { Max } \\
\text { Temp C }\end{array}$ \\
\hline 2014 & 5 & $6.6(4.8) 3455$ & $14(3.4) 60$ & -5.6 & 7.2 & 19.1 & 19.1 \\
\hline 2014 & 6 & 8.9 (3.9) 2579 & $14.7(2.7) 176$ & 1.1 & 5.5 & 20.9 & 20.8 \\
\hline 2014 & 7 & 14.9 (4.3) 2228 & 18.8 (3.5) 453 & 2.7 & 4.9 & 25.1 & 25.1 \\
\hline 2014 & 8 & $14.1(3.4) 1521$ & 17.8 (3.5) 147 & 7 & 9 & 23.1 & 22.6 \\
\hline 2014 & 9 & 3 & 3 & 3 & 3 & 3 & 3 \\
\hline 2014 & 10 & $6(4.4) 2934$ & $13.7(1.2) 3$ & -4.3 & 13 & 15.3 & 15.1 \\
\hline
\end{tabular}

1 Temperatures should only be regarded as being indicative of the general temperature at the time of detection. Temperatures were recorded at the detector approximately 1 meter above ground level while microphones were mounted at approximately 3 meters above ground level and bats were in flight at an unknown altitude, but probably typically within 30 meters of ground level. Temperatures of the bat's roost environment at the time flights were initiated are also obviously unknown.

2 It appears that the SM2 detector/recorder failed to record temperatures below $-20.5^{\circ} \mathrm{C}$ given that it was the lowest temperature recorded on eight separate months.

3 No calls recorded. See Table 3 for periods of time when microphones had lost sensitivity or the detector recorder had power issues and may not have been functioning properly. There were large time periods between 26 June and 25 October of 2014 when the detector/recorder was not properly powered.

4 Cannot calculate standard deviation with a single value. 
Table 10. Monthly minimum bat pass temperatures $\left({ }^{\circ} \mathrm{C}\right)$ recorded for individual species hand confirmed as definitively present ${ }^{1}$

\begin{tabular}{|c|c|l|l|l|l|l|l|l|l|l|l|l|l|}
\hline Species $^{2}$ & Year & Jan & Feb & March & April & May & June & July & Aug & Sept & Oct & Nov & Dec \\
\hline EPFU & 2012 & & & & & & 16.6 & 19.3 & 15.8 & 16.1 & 17.4 & & \\
\hline EPFU & 2013 & & & & & & & & 15.6 & & 2.2 & & \\
\hline EPFU & 2014 & & & & & & 14.5 & & & & & & \\
\hline LACl & 2012 & & & & & & & 16.8 & 17.1 & 13.2 & & & \\
\hline LACl & 2013 & & & & & & & & 19.9 & 4.4 & & & \\
\hline LACl & 2014 & & & & & & & 15.6 & 15.8 & & & & \\
\hline LANO & 2012 & & & 5.7 & 5.7 & 15 & 19.6 & 16.1 & 15.1 & 16.3 & 4.4 & 4.7 & \\
\hline LANO & 2013 & & & & 9.2 & & & & & 18.1 & 3.1 & & \\
\hline LANO & 2014 & & & & & 19.1 & & 17.1 & 17 & & & & \\
\hline MYCI & 2012 & & & & & 18.9 & 6.2 & 17.4 & 8.7 & 14.6 & & & \\
\hline MYCI & 2013 & & & 7.2 & 6.5 & 12.8 & & 21.4 & 11 & 13 & & & \\
\hline MYCI & 2014 & & & & & 16.5 & & 15.1 & 19.9 & & & & \\
\hline MYEV & 2012 & & & & & 12 & 8.9 & 8 & 15 & 11 & 10.3 & & \\
\hline MYEV & 2013 & & & & & 6.7 & 10.2 & 22.9 & 8.2 & & & & \\
\hline MYEV & 2014 & & & & & 8.7 & 11.8 & 13.8 & 17 & & & & \\
\hline MYLU & 2012 & & & & & 8.5 & 10.7 & 12.2 & 18.4 & 17.9 & 9.7 & & \\
\hline MYLU & 2013 & & & & 14.5 & 12.7 & & 14 & 15.6 & 18.9 & 11.3 & & \\
\hline MYLU & 2014 & & & & & & & 20.3 & 19.9 & & & & \\
\hline
\end{tabular}

${ }^{1}$ Temperatures should only be regarded as being indicative of the general temperature at the time of detection. Temperatures were recorded at the detector approximately 1 meter above ground level while microphones were mounted at approximately 3 meters above ground level and bats were in flight at an unknown altitude, but probably typically within 30 meters of ground level. Temperatures of the bat's roost environment at the time flights were initiated are also obviously unknown.

2 Species codes are the first two letters of the genus and species names. 
Table 11. Minimum bat pass temperatures recorded for definitive call sequences of species across the detector network and at the Big Sheep Creek detector ${ }^{1}$

\begin{tabular}{|c|c|c|}
\hline Species & $\begin{array}{c}\text { Minimum } \\
\text { Temperature } \\
\text { Recorded }\left({ }^{\circ} \mathrm{C}\right) \\
\text { Across Network }{ }^{2}\end{array}$ & $\begin{array}{c}\text { Minimum } \\
\text { Temperature } \\
\text { Recorded }\left({ }^{\circ} \mathrm{C}\right) \text { at Big } \\
\text { Sheep Detector }{ }^{3}\end{array}$ \\
\hline $\begin{array}{c}\text { Pallid Bat } \\
\text { (Antrozous pallidus) }\end{array}$ & 5.2 & na \\
\hline $\begin{array}{l}\text { Townsend's Big-eared Bat } \\
\text { (Corynorhinus townsendii) }\end{array}$ & 6.0 & na \\
\hline $\begin{array}{c}\text { Big Brown Bat } \\
\text { (Eptesicus fuscus) }\end{array}$ & -4.8 & 2.2 \\
\hline $\begin{array}{c}\text { Spotted Bat } \\
\text { (Euderma maculatum) }\end{array}$ & 1.9 & na \\
\hline $\begin{array}{c}\text { Eastern Red Bat } \\
\text { (Lasiurus borealis) }\end{array}$ & 1.6 & na \\
\hline $\begin{array}{c}\text { Silver-haired Bat } \\
\text { (Lasionycteris noctivagans) }\end{array}$ & -4.9 & 3.1 \\
\hline $\begin{array}{c}\text { Hoary Bat } \\
\text { (Lasiurus cinereus) }\end{array}$ & -0.6 & 4.4 \\
\hline $\begin{array}{l}\text { California Myotis } \\
\text { (Myotis californicus) }\end{array}$ & -0.5 & na \\
\hline $\begin{array}{c}\text { Western Small-footed Myotis } \\
\text { (Myotis ciliolabrum) }\end{array}$ & -4.8 & 6.2 \\
\hline $\begin{array}{l}\text { Long-eared Myotis } \\
\text { (Myotis evotis) }\end{array}$ & -2.1 & 6.7 \\
\hline $\begin{array}{l}\text { Little Brown Myotis } \\
\text { (Myotis lucifugus) }\end{array}$ & -0.5 & 8.5 \\
\hline $\begin{array}{c}\text { Fringed Myotis } \\
\text { (Myotis thysanodes) }\end{array}$ & 3.1 & na \\
\hline $\begin{array}{l}\text { Long-legged Myotis } \\
\text { (Myotis volans) }\end{array}$ & 5.5 & na \\
\hline $\begin{array}{c}\text { Yuma Myotis } \\
\text { (Myotis yumanensis) }\end{array}$ & 6.7 & na \\
\hline
\end{tabular}

${ }^{1}$ Temperatures should only be regarded as being indicative of the general temperature at the time of detection. Temperatures were recorded at the detector approximately 1 meter above ground level while microphones were mounted at approximately 3 meters above ground level and bats were in flight at an unknown altitude, but probably typically within 30 meters of ground level. Temperatures of the bat's roost environment at the time flights were initiated are also obviously unknown.

2 Probable call sequences of Big Brown Bat $\left(-8.4^{\circ} \mathrm{C}\right)$, Silver-haired Bat $\left(-7.4^{\circ} \mathrm{C}\right)$, Hoary Bat $\left(-2^{\circ} \mathrm{C}\right)$, Western Smallfooted Myotis $\left(-8.6^{\circ} \mathrm{C}\right)$, Long-eared Myotis $\left(-2.9^{\circ} \mathrm{C}\right)$ were also recorded.

3 Probable call sequences of Big Brown Bat (0.6), Big Brown Bat or Silver-haired Bat $\left(-0.1^{\circ} \mathrm{C}\right)$, Western Small-footed Myotis $\left(5.5^{\circ} \mathrm{C}\right)$, Long-eared Myotis $\left(5.7^{\circ} \mathrm{C}\right)$, and Little Brown Myotis $\left(3.9^{\circ} \mathrm{C}\right)$ were also recorded. na $=$ outside species' range or not documented in this study. 
Figure 1. Network of long term ultrasonic acoustic detectors as of December 2015

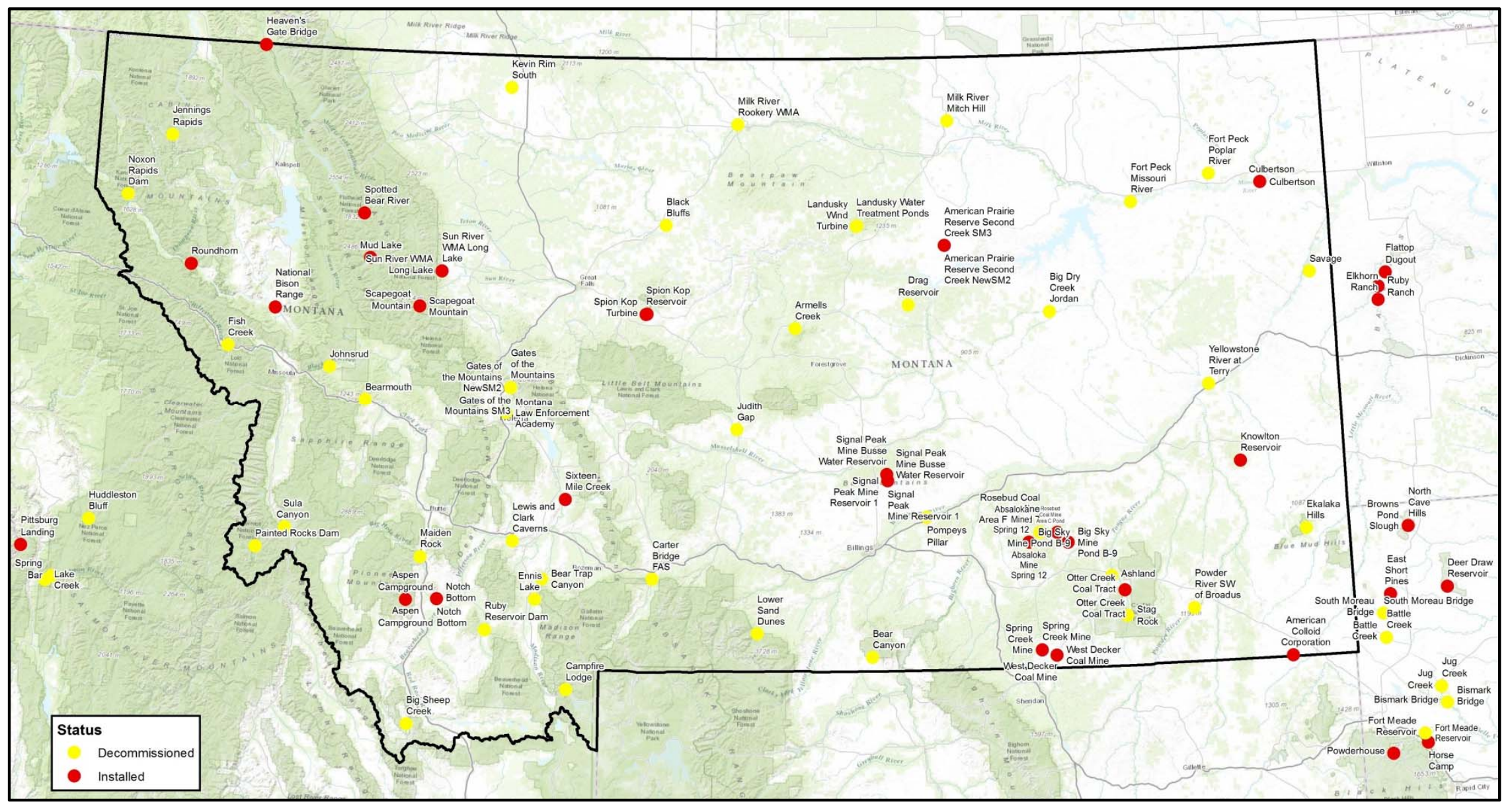


Figure 2. Location of the Big Sheep Creek detector recorder ( $\operatorname{red} x$ ) within the Tendoy Mountains and Harkness weather station (red circle) at landscape (a) and local (b) views.

(a)

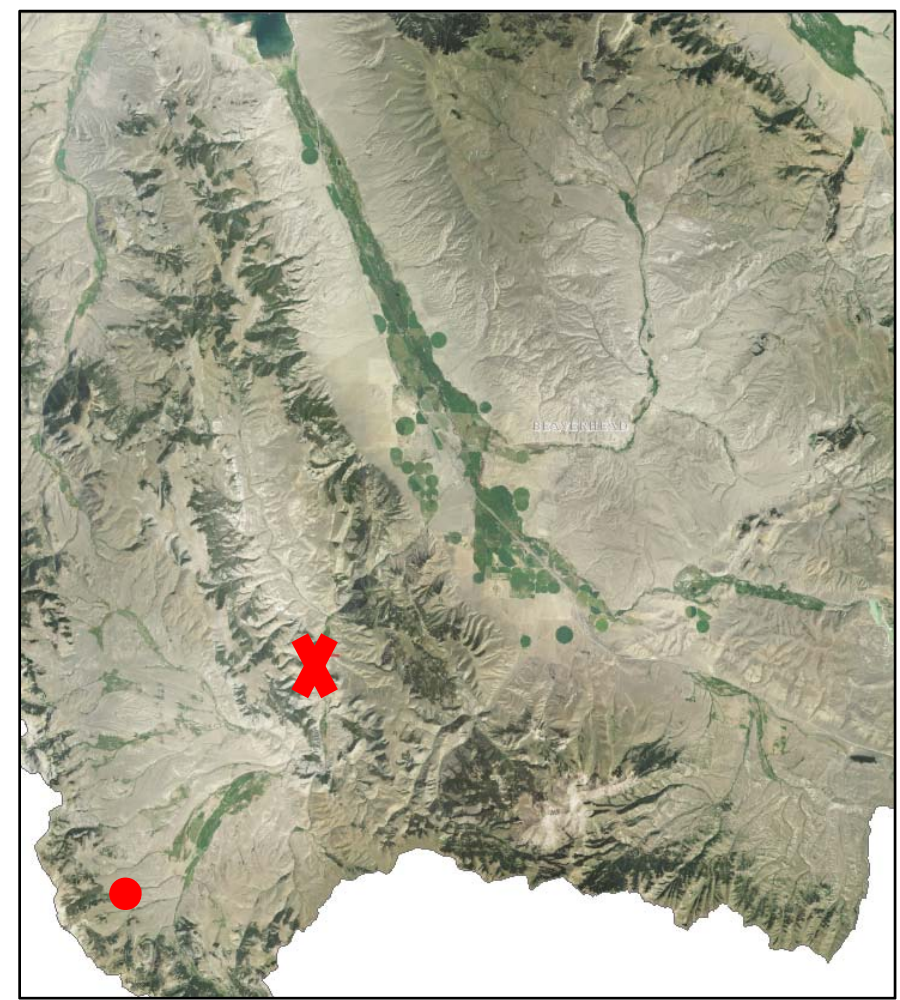

(b)

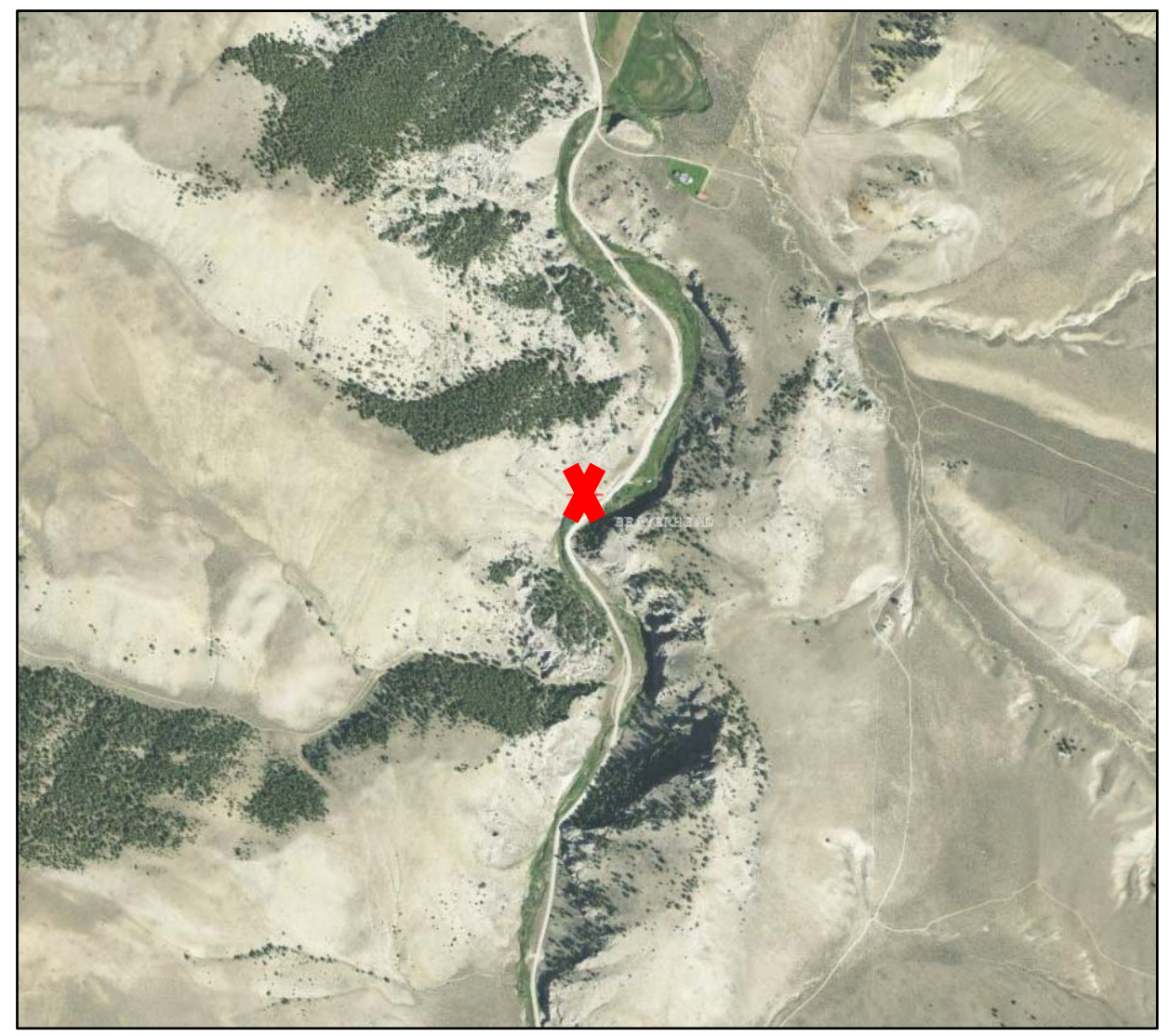


Figure 3. Downslope (a) and upslope (b) views of bat detector on Big Sheep Creek. SM2 Bat+ detector/recorder and solar panel (red squares) and microphone (red star).

(a)

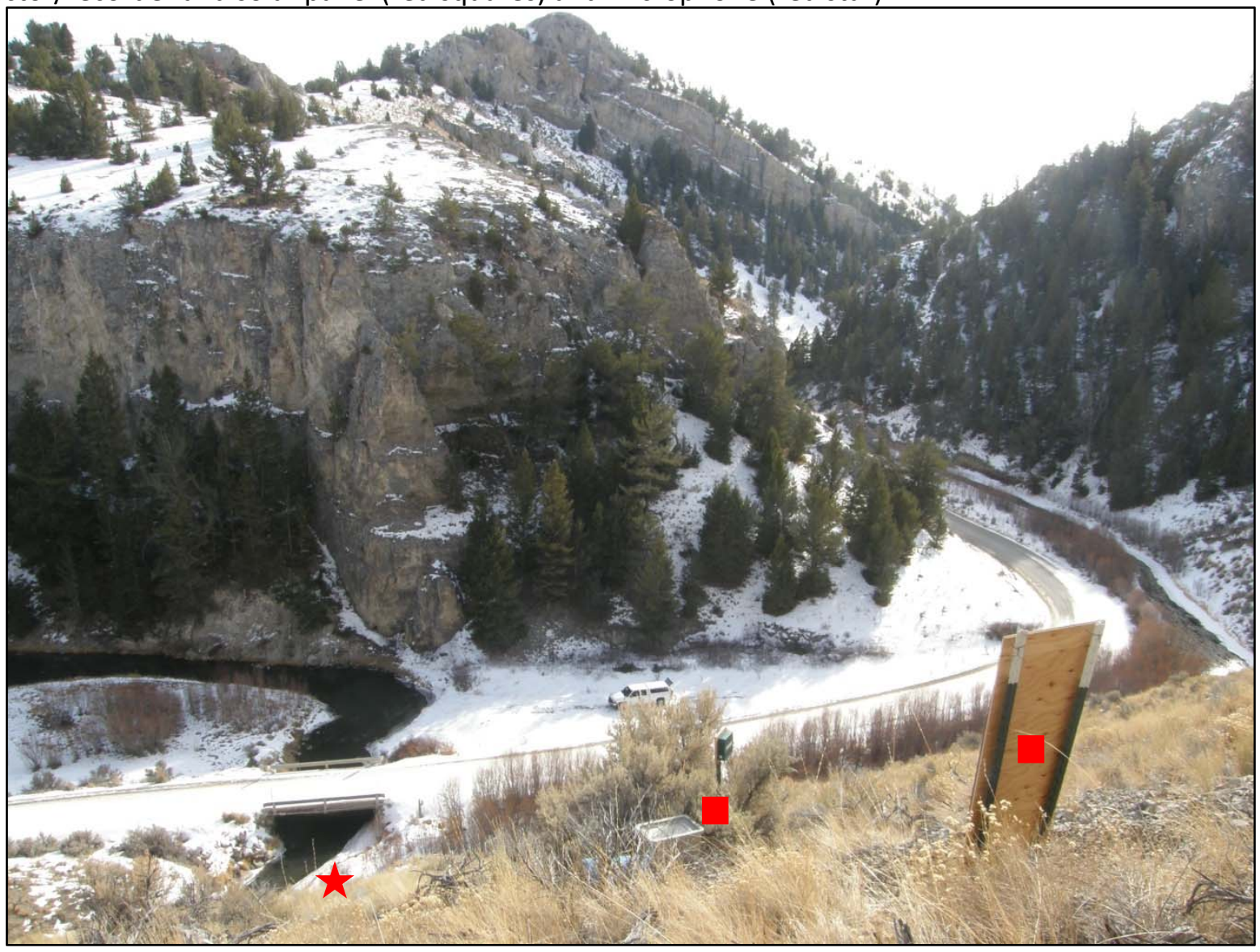

(b)

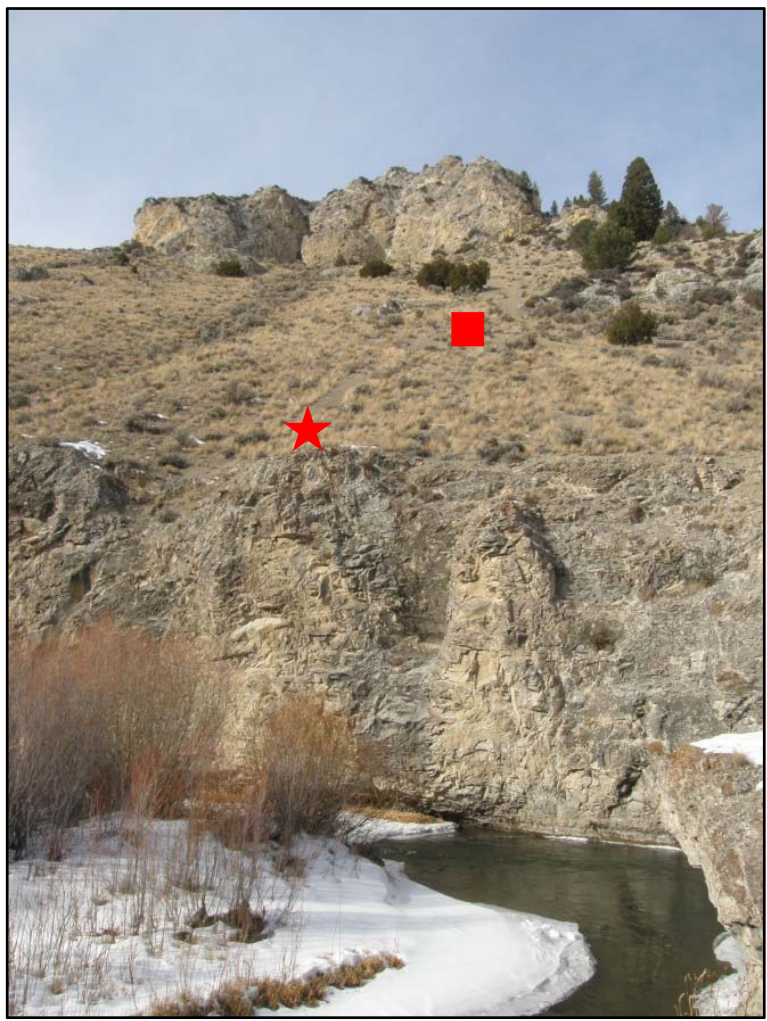


Figure 4. Percent of call sequences auto-identified to species each month.

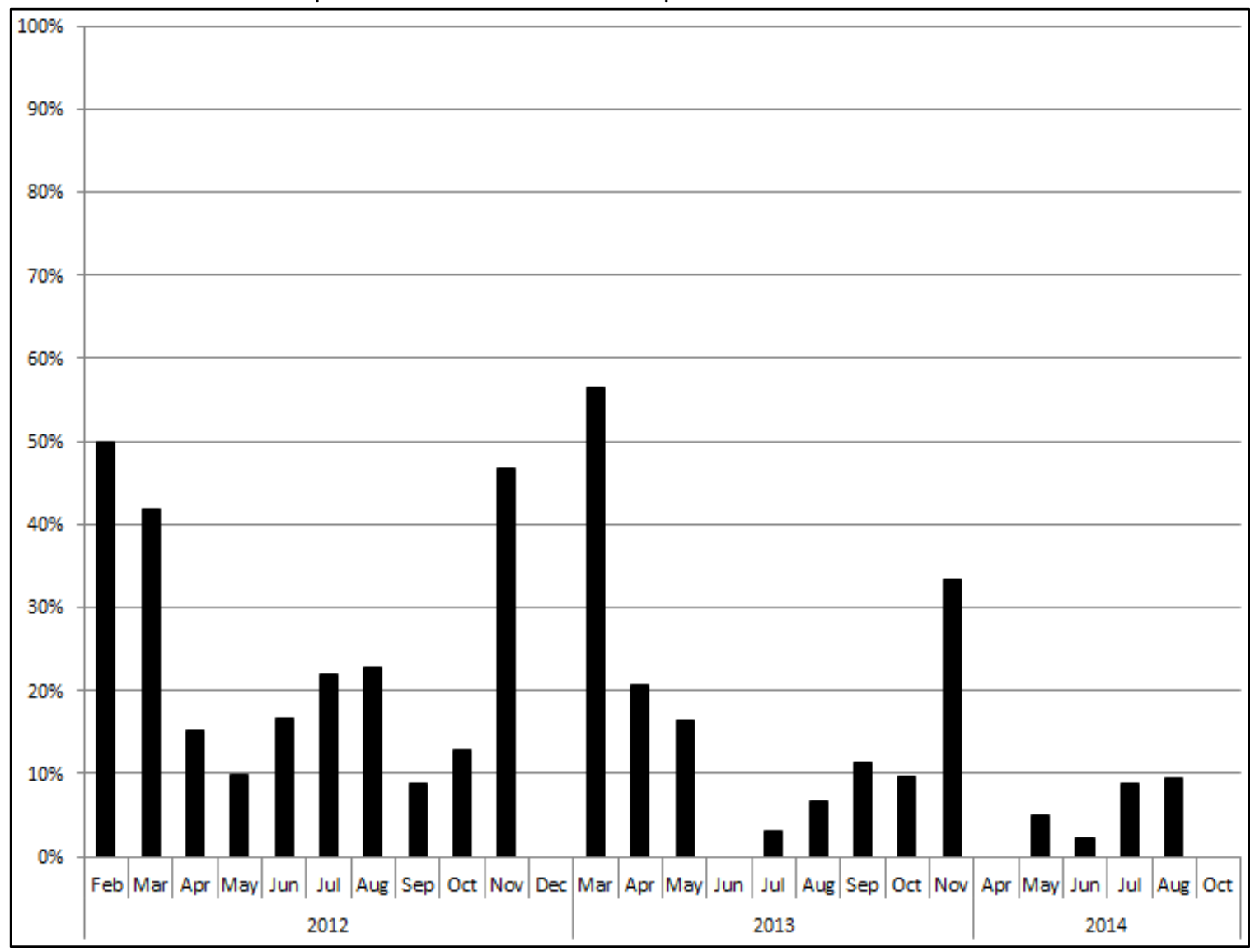

Figure 5. Average (blue) and maximum counts (red) of bat passes per night by month. Numbers on Xaxis are years and months.

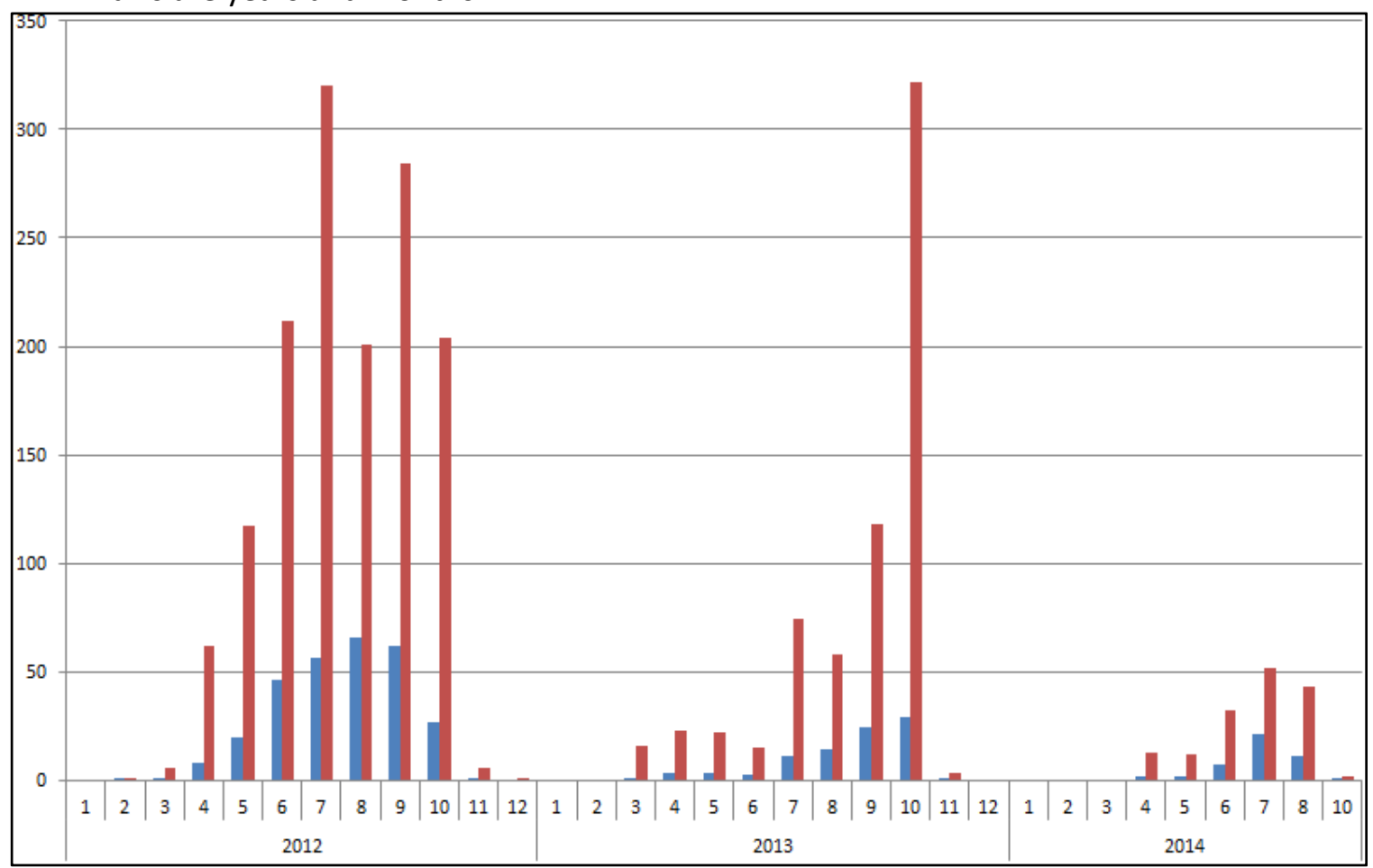


Figure 6. Average number of bat passes per night by week for active season (a) and inactive season (b). Numbers on $\mathrm{X}$ axis are years, months, and weeks.

(a)

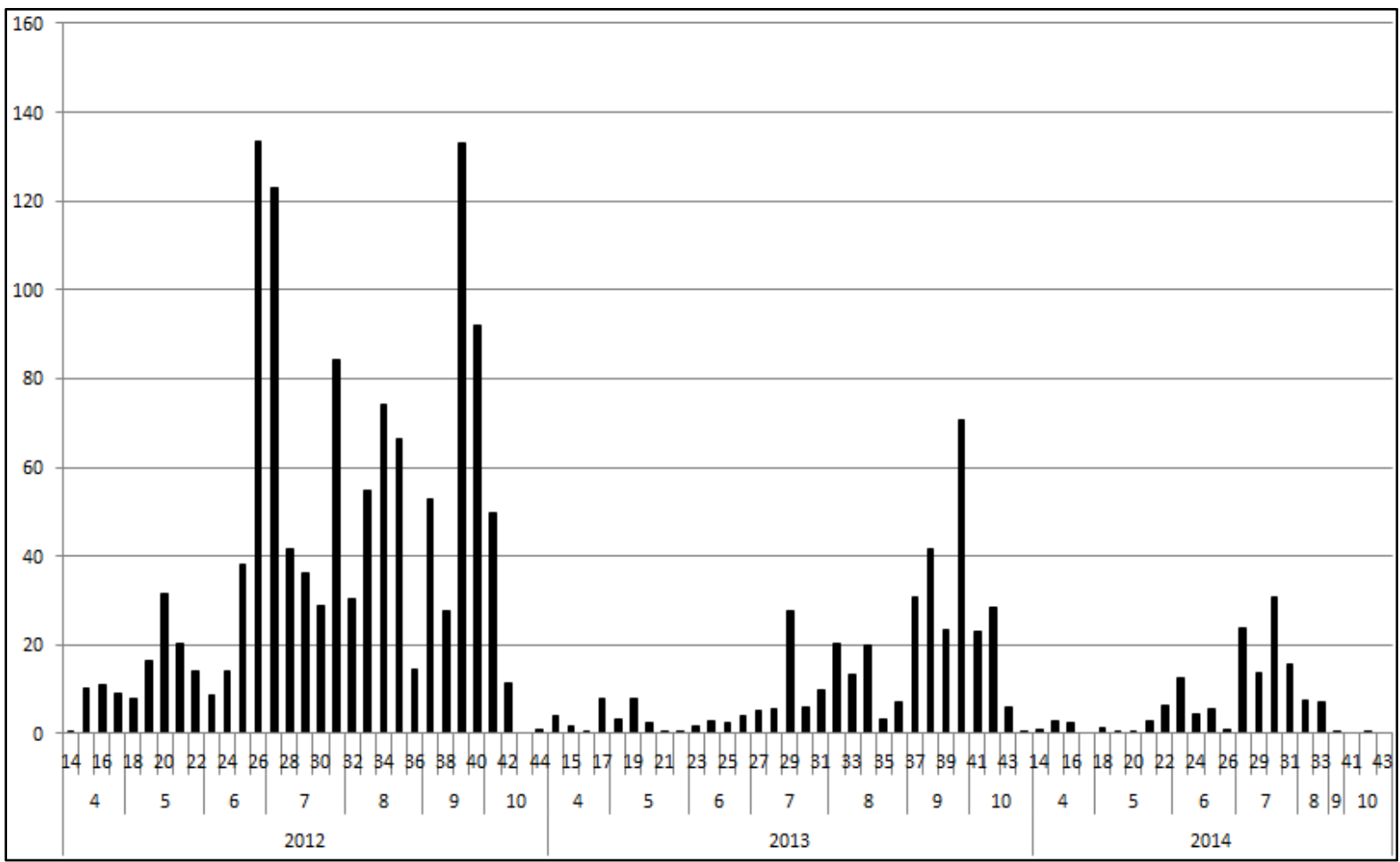

(b)

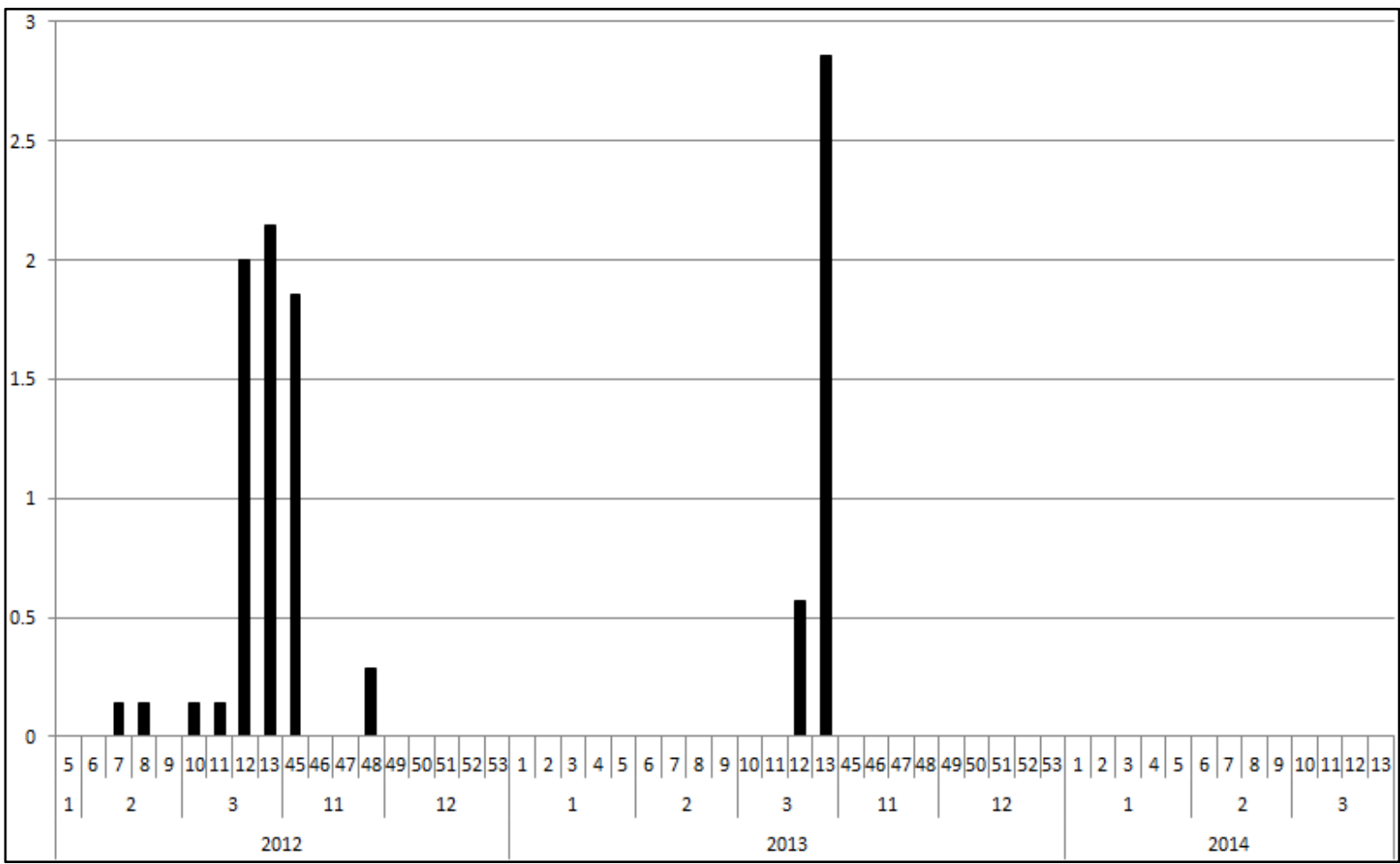


Figure 7. Average number of bat passes per night by week across the detector network for active season (a) and inactive season (b). Numbers on $\mathrm{X}$ axis are years, months, and weeks.

(a)

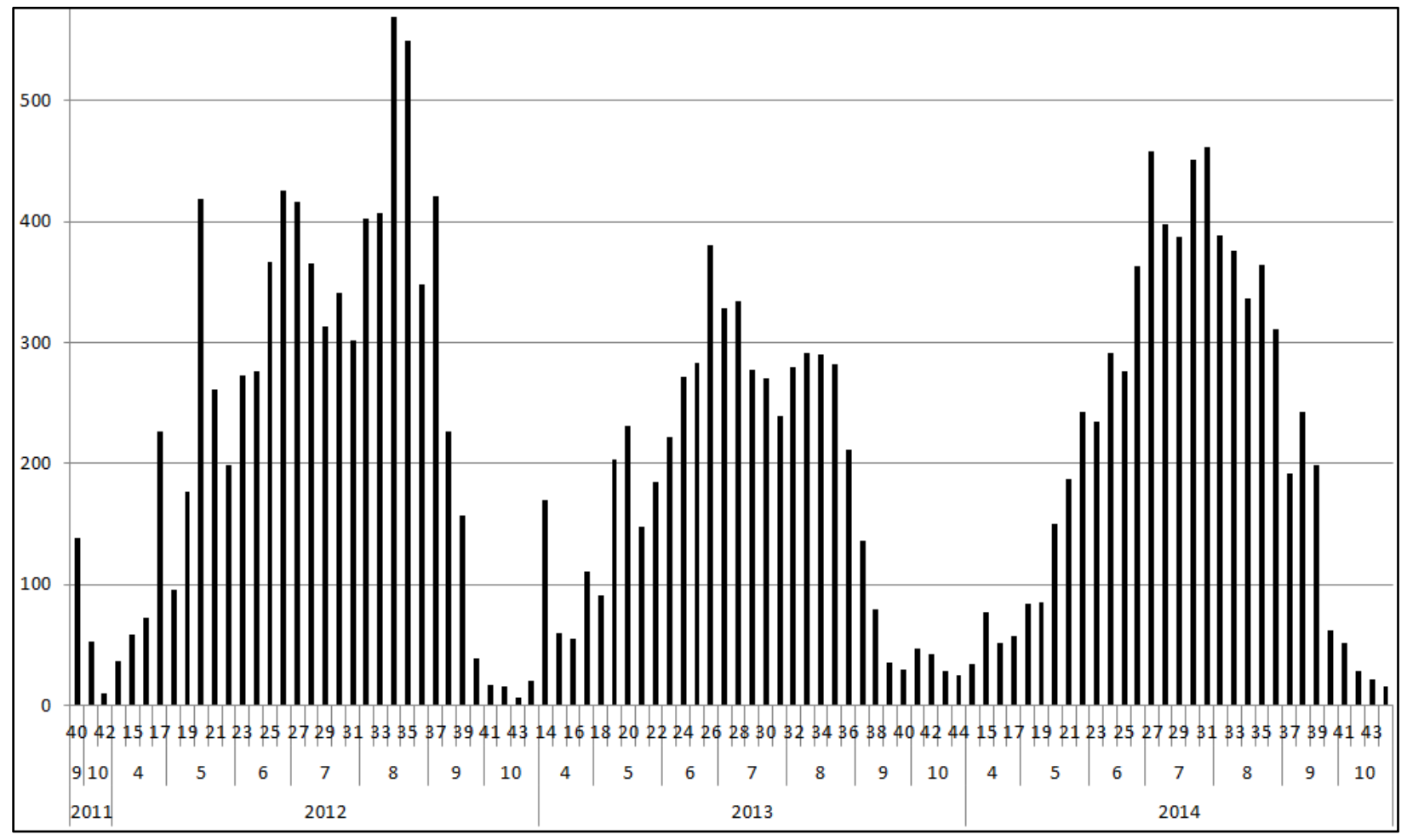

(b)

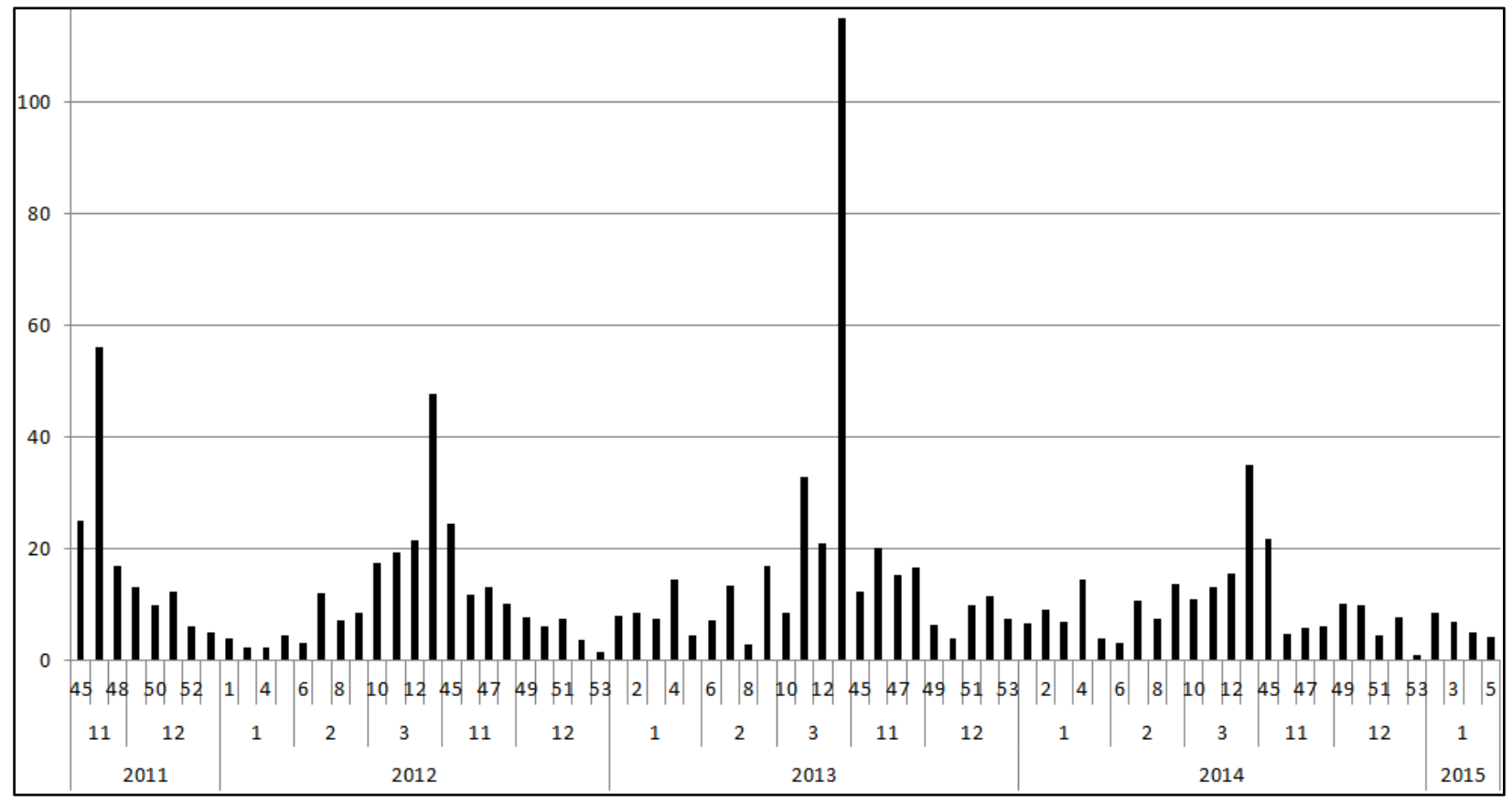


Figure 8. Total number of bat passes per night by week across the detector network and across all years for active season (a) and inactive season (b) as of fall 2015.

(a)

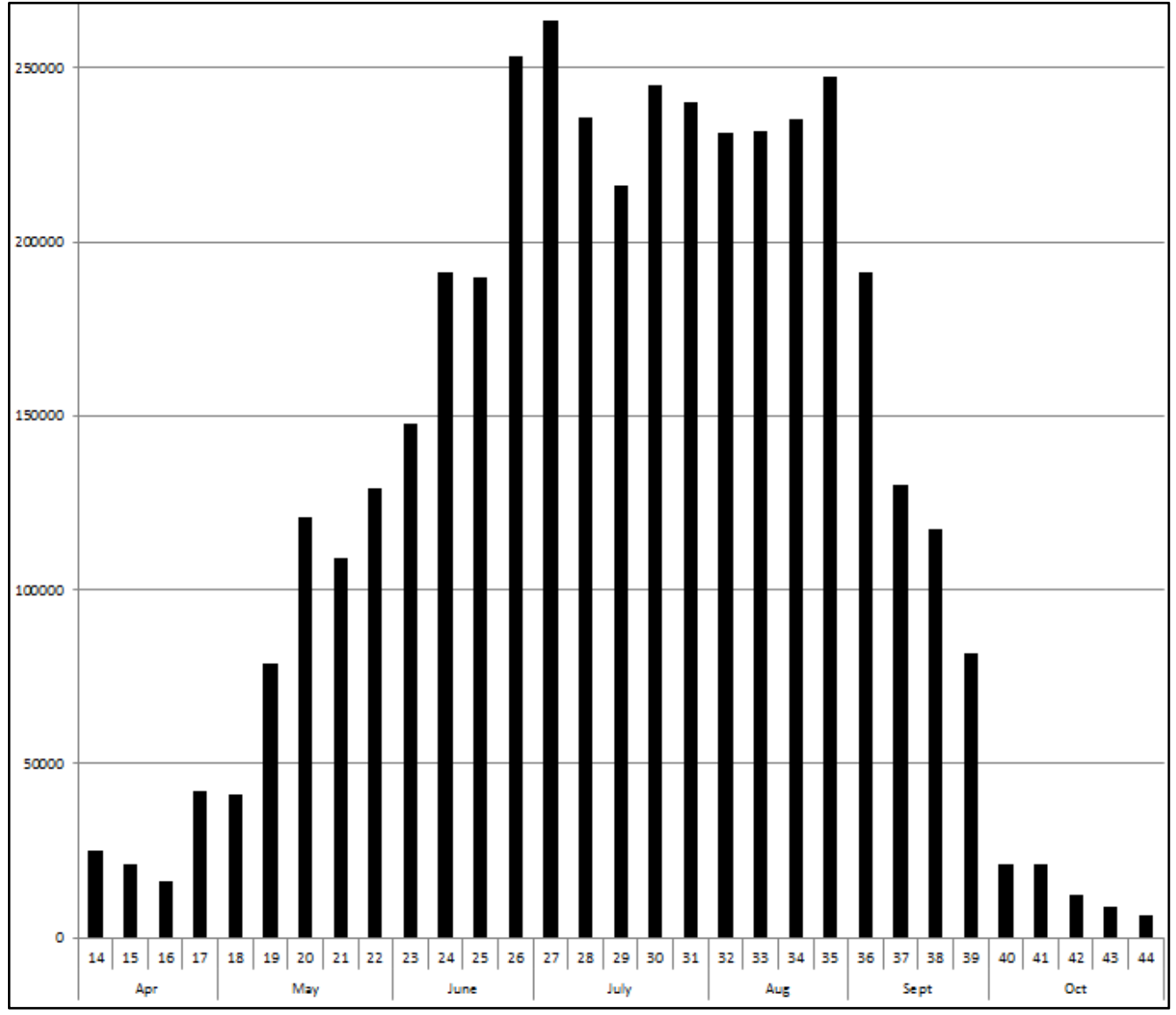

(b)

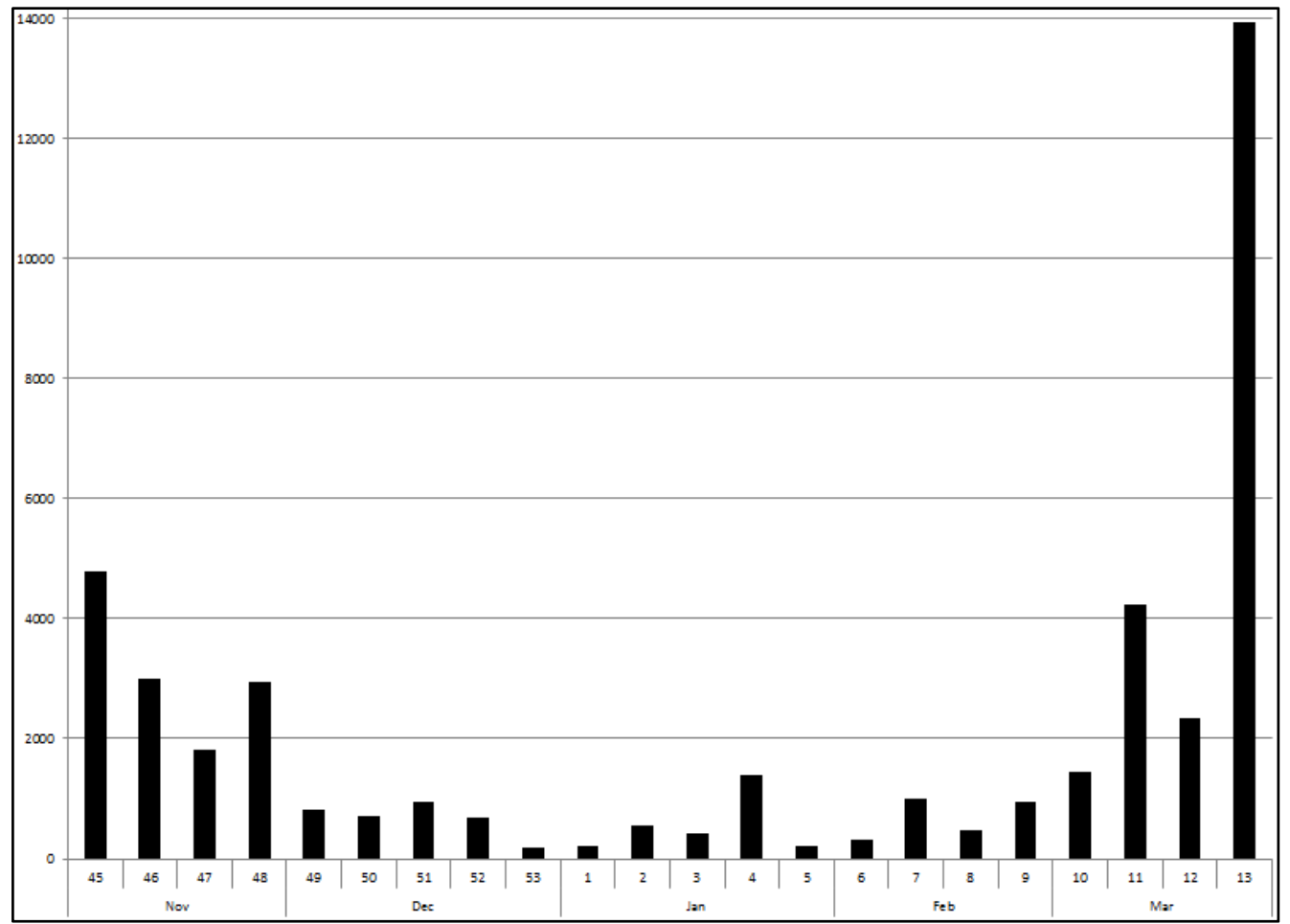


Figure 9. Average number of bat passes each hour after sunset across all years during active (a) and inactive season (b). Numbers on $\mathrm{X}$ axis are months and weeks.

(a)

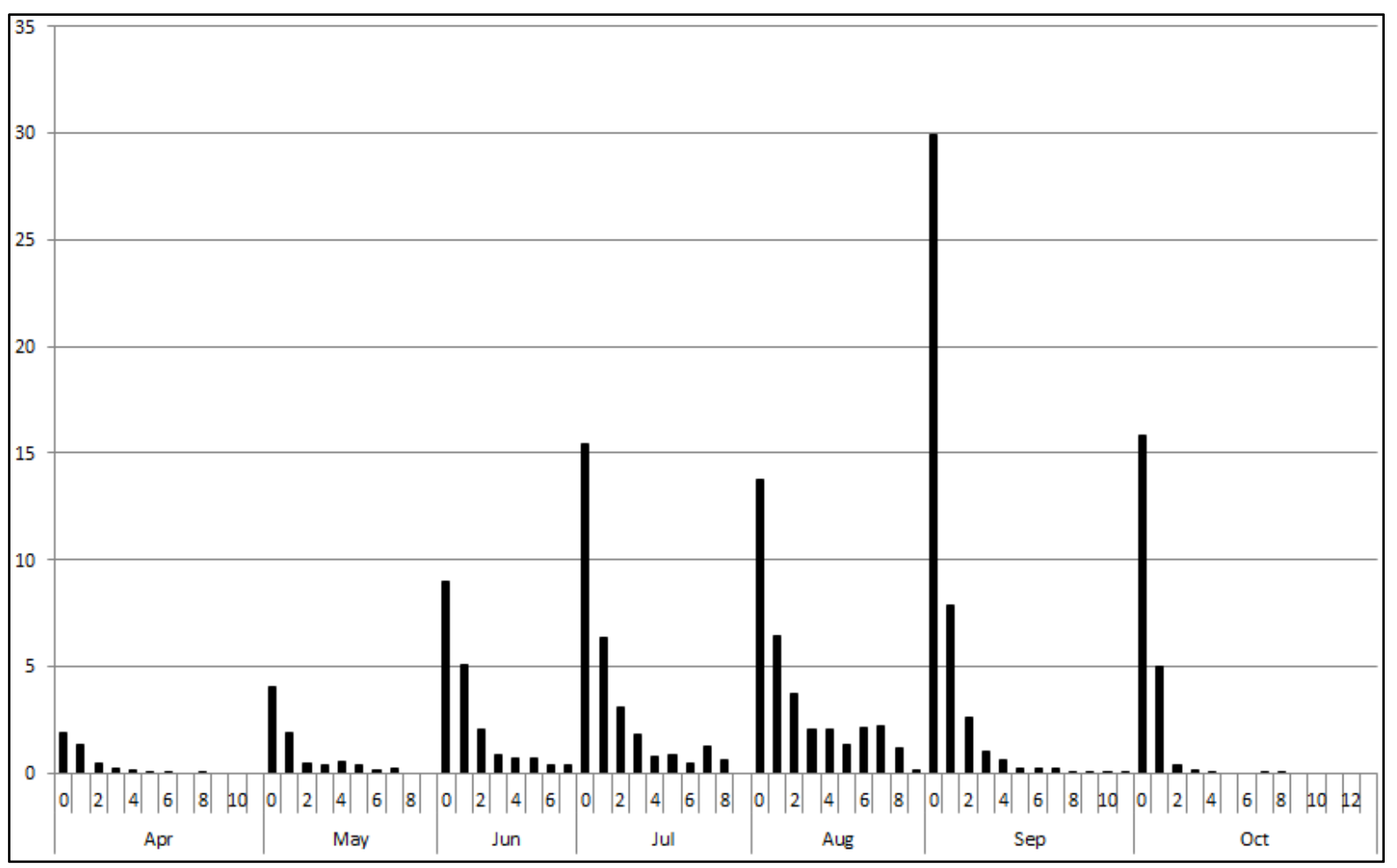

(b)

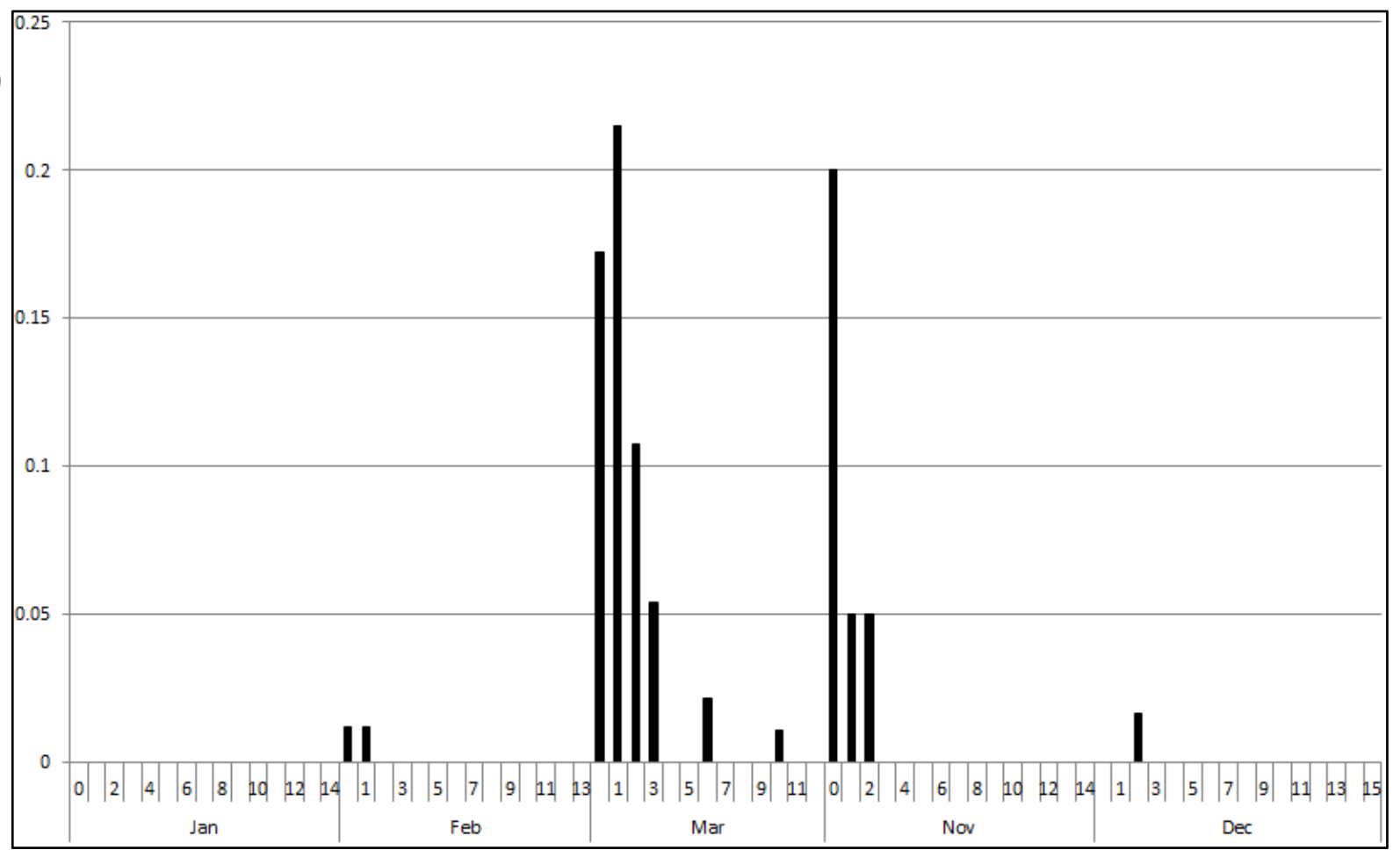


Figure 10. Average nightly background (blue) and bat pass (red) temperatures by month. Numbers on X axis are years and months.

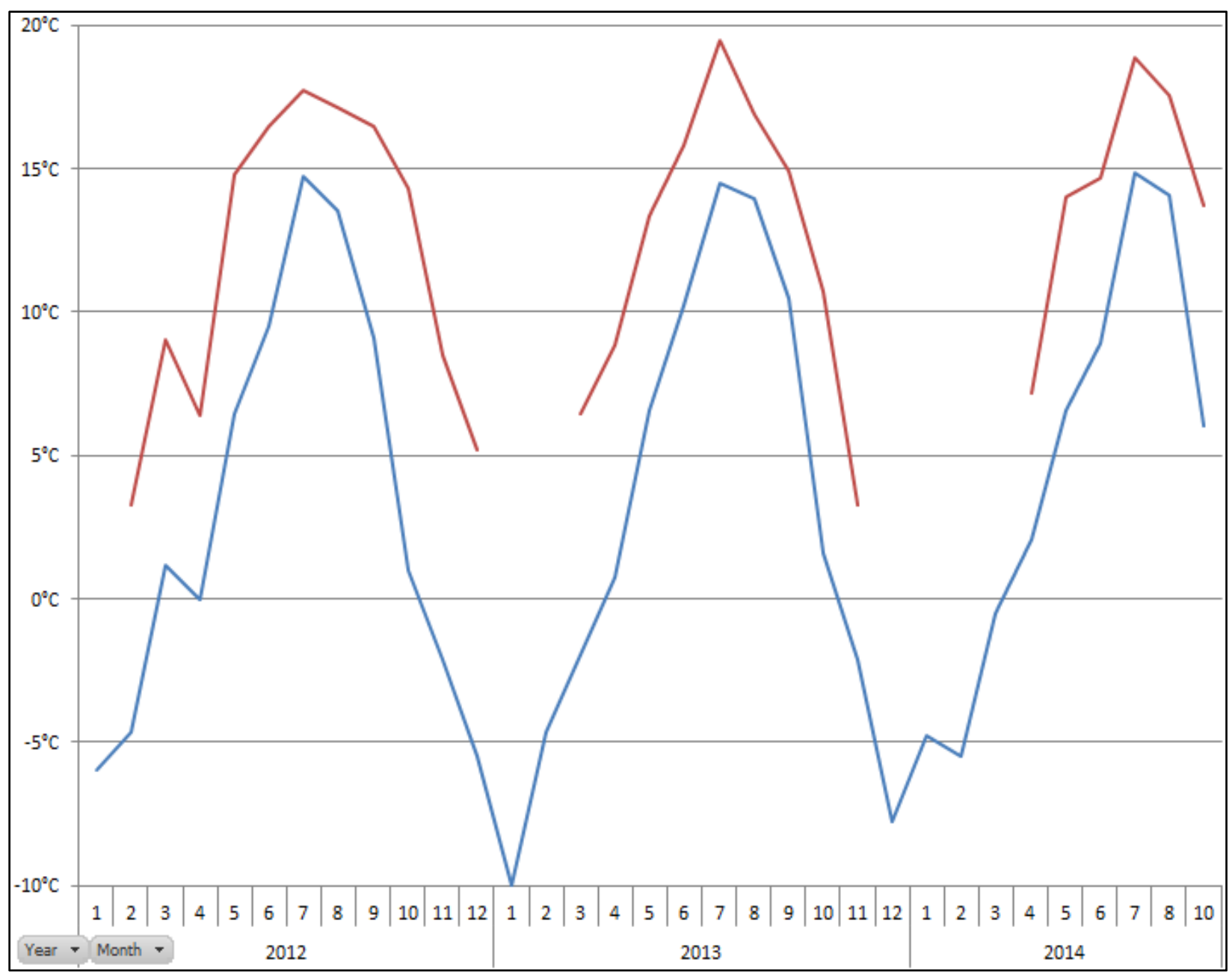


Figure 11. Percent of nightly hours with average background temperatures (blue) and average temperatures associated with bat passes (red) for the Harkness weather station which is 20.1 kilometers to the southwest. Numbers are lower ends of ${ }^{\circ} \mathrm{C}$ temperature bins.

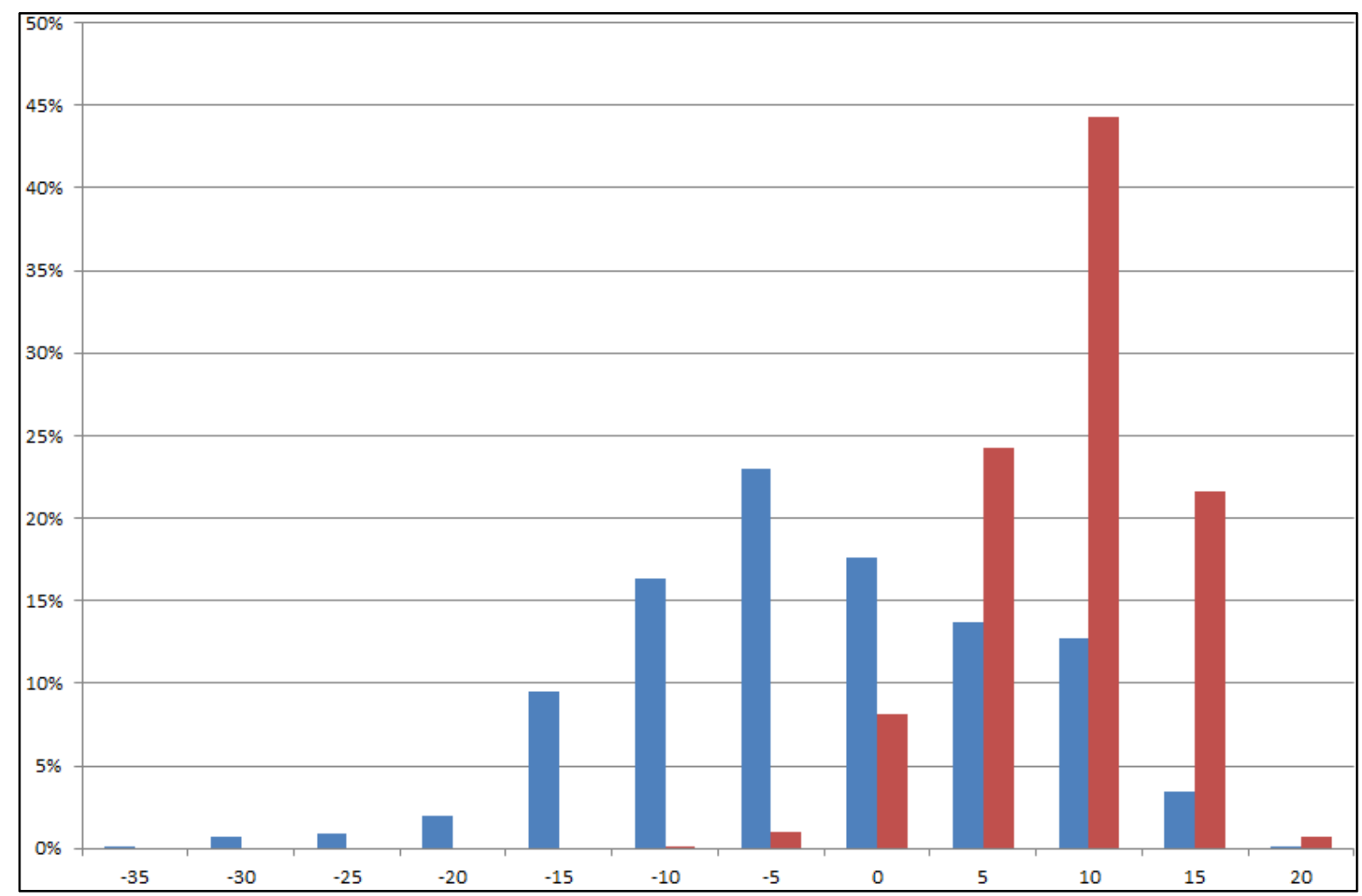


Figure 12. Percent of nightly hours with average background temperatures (blue) and average temperatures associated with bat passes (red) across the regional network of detectors. Numbers are lower ends of ${ }^{\circ} \mathrm{C}$ temperature bins. Of the 467,512 hours that detectors have been deployed, temperature data was available from nearby weather stations for 457,613 hours $(98 \%)$. Note that some detectors were up to 43 kilometers from the weather station where temperatures were recorded $(X=14.9 \mathrm{~km}, \mathrm{SD}=10.3 \mathrm{~km})$.

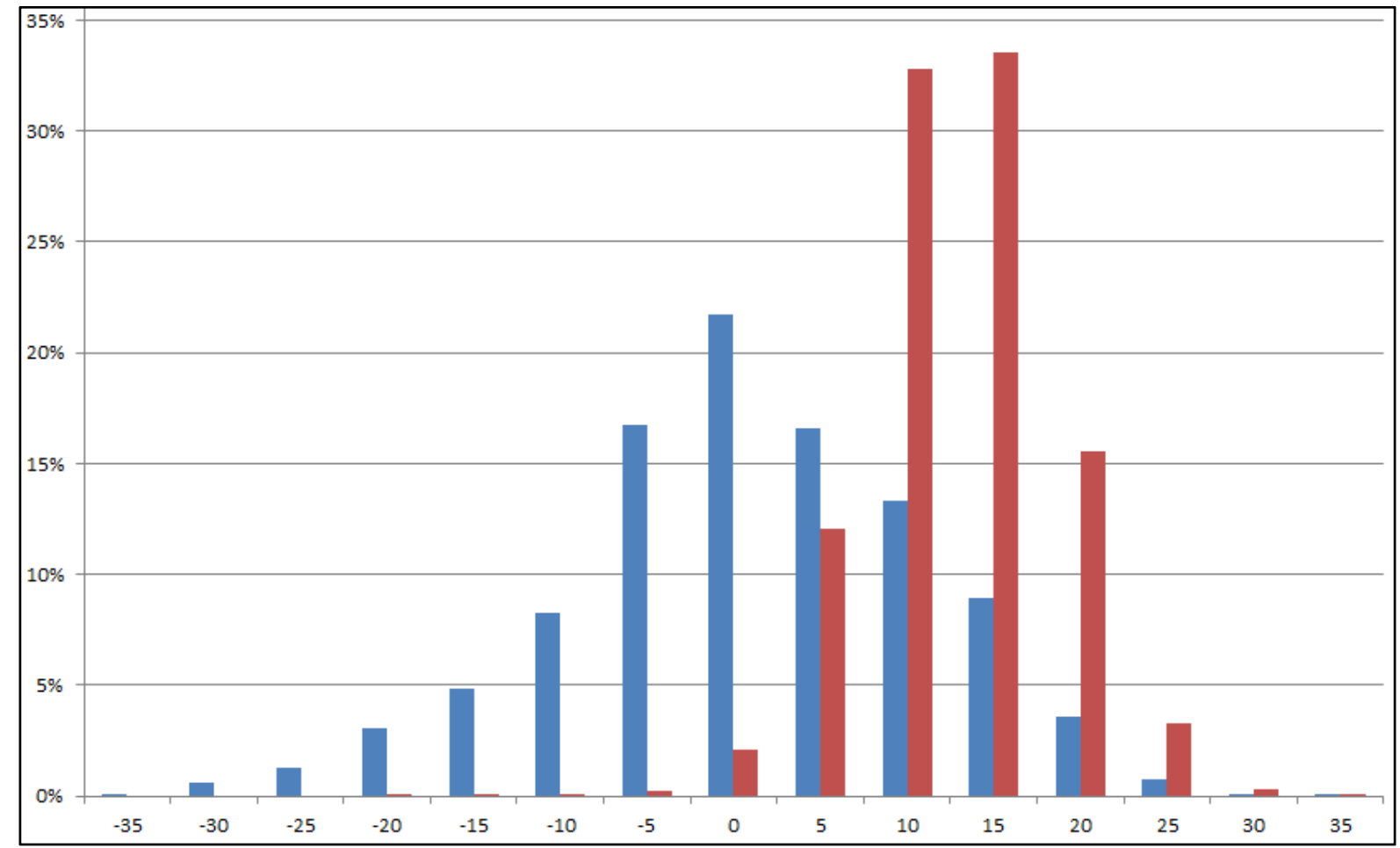


Figure 13. Percent of hours with average background wind speeds (blue) and average wind speeds associated with bat passes (red) at the Harkness weather station which is 20.1 kilometers to the southwest. Wind speed categories are meters per second.

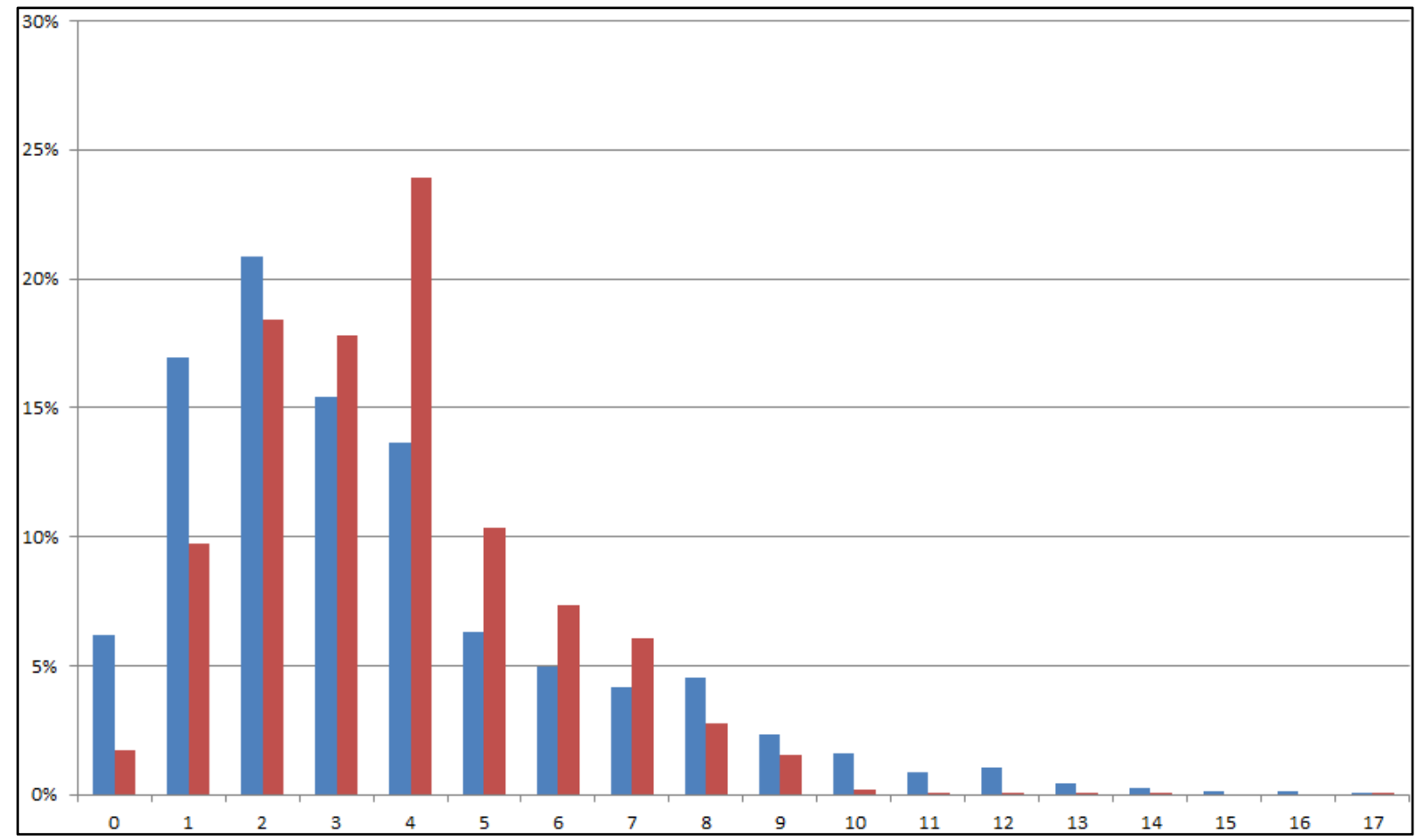


Figure 14. Percent of hours with average background wind speeds (blue) and average wind speeds associated with bat passes (red) across the regional network of detectors. Wind speed categories are meters per second. Of the 467,512 hours that detectors have been deployed, wind speed data was available from nearby weather stations for 455,361 hours (97\%). Note that some detectors were up to 43 kilometers from the weather station where wind speeds were recorded $(X=16.9 \mathrm{~km}, S D=10.5 \mathrm{~km})$.

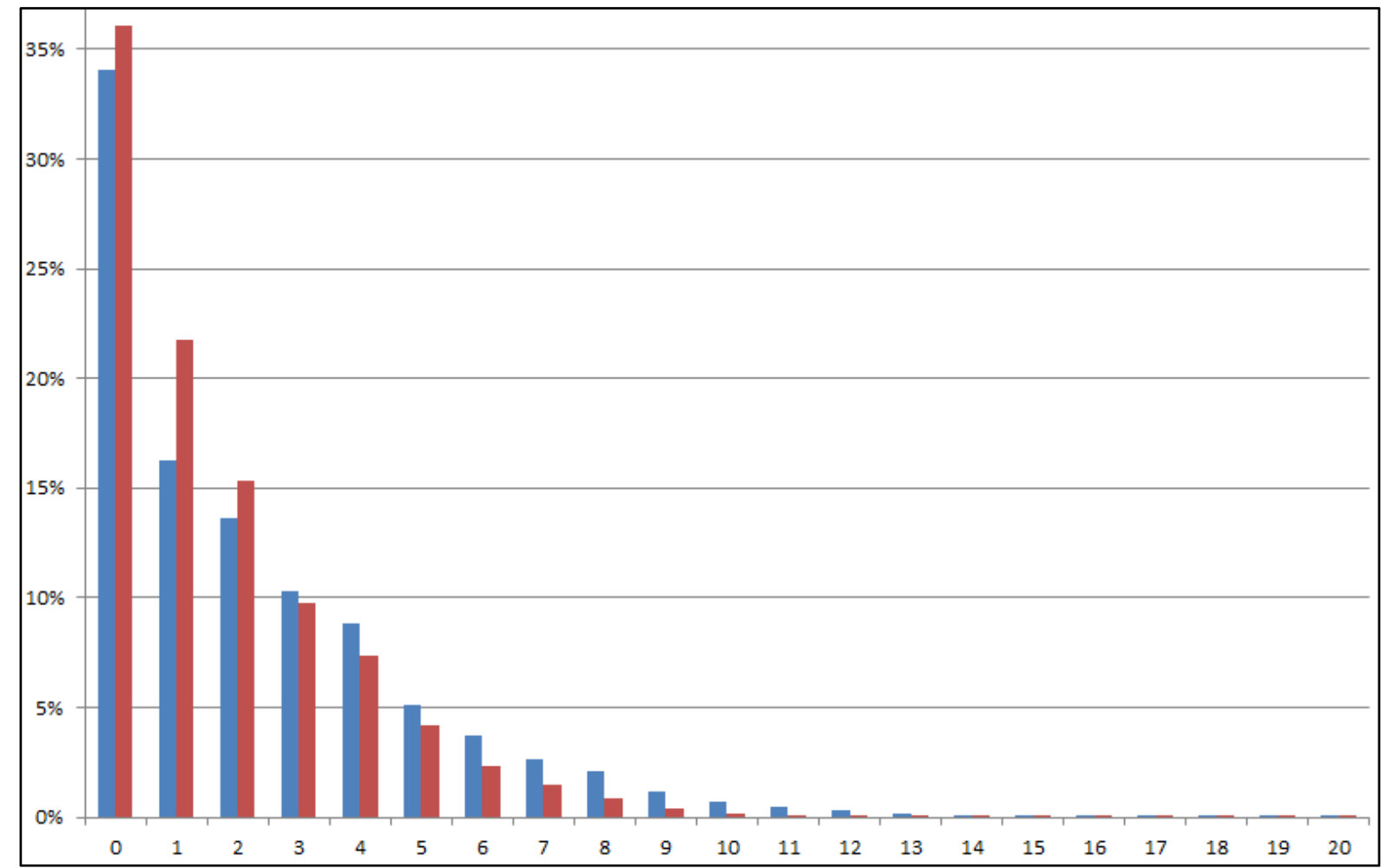


Figure 15. Percent of hours with background barometric pressure changes (blue) and barometric pressure changes associated with bat passes (red) at the Dillon Airport weather station which is 74.4 kilometers to the north-northeast. Numbers shown are the lower ends of categories of millibars of change per hour.

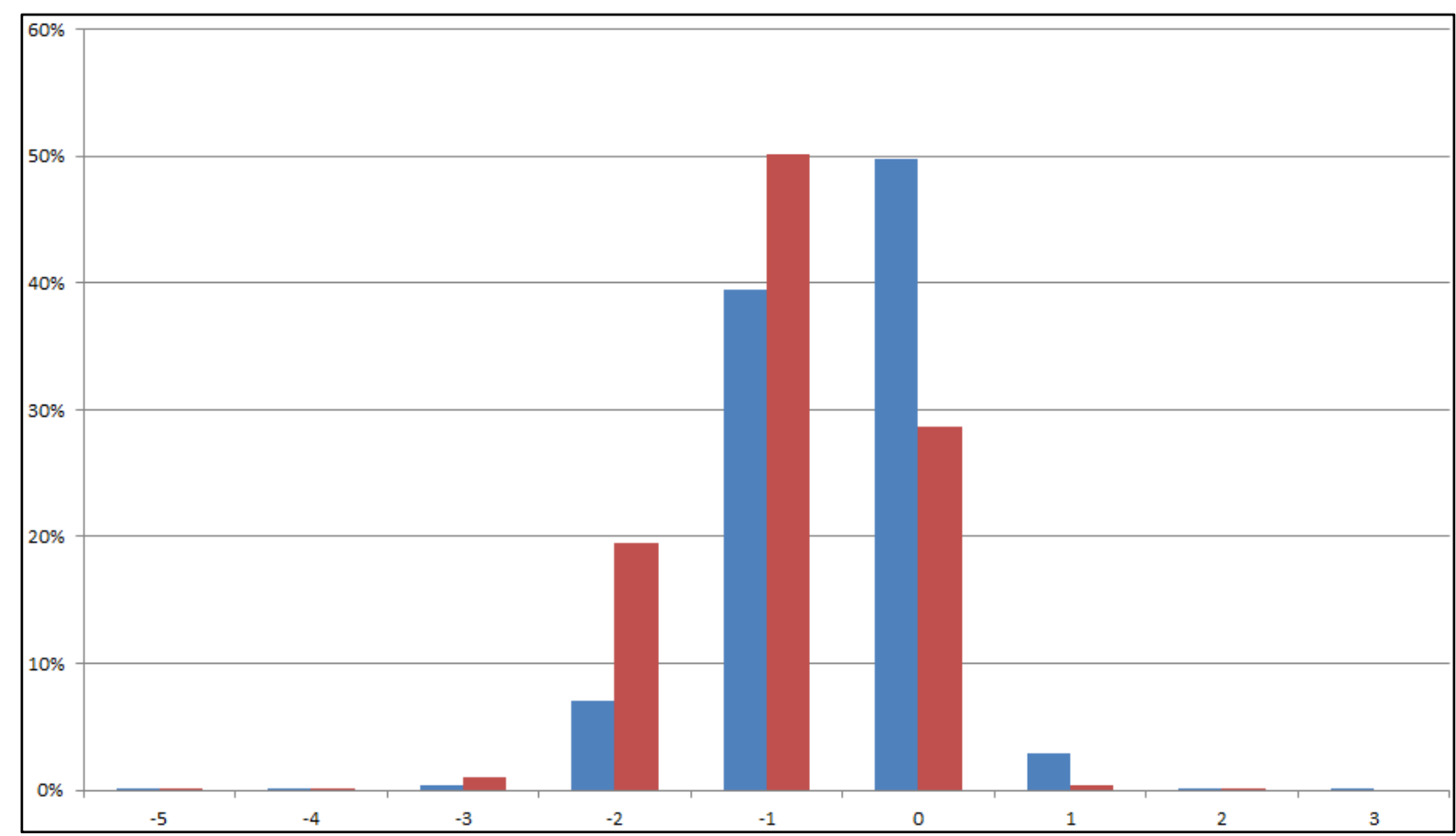


Figure 16. Percent of hours with background barometric pressure changes (blue) and barometric pressure changes associated with bat passes (red) across the regional network of detectors. Numbers shown are the lower ends of categories of millibars of change per hour. Of the 467,512 hours that detectors have been deployed, barometric pressure data was available from nearby weather stations for 420,412 hours (90\%). Note that some detectors were up to 94 kilometers from the weather station where barometric pressures were recorded $(X=35.4$ $\mathrm{km}, \mathrm{SD}=21.5 \mathrm{~km})$.

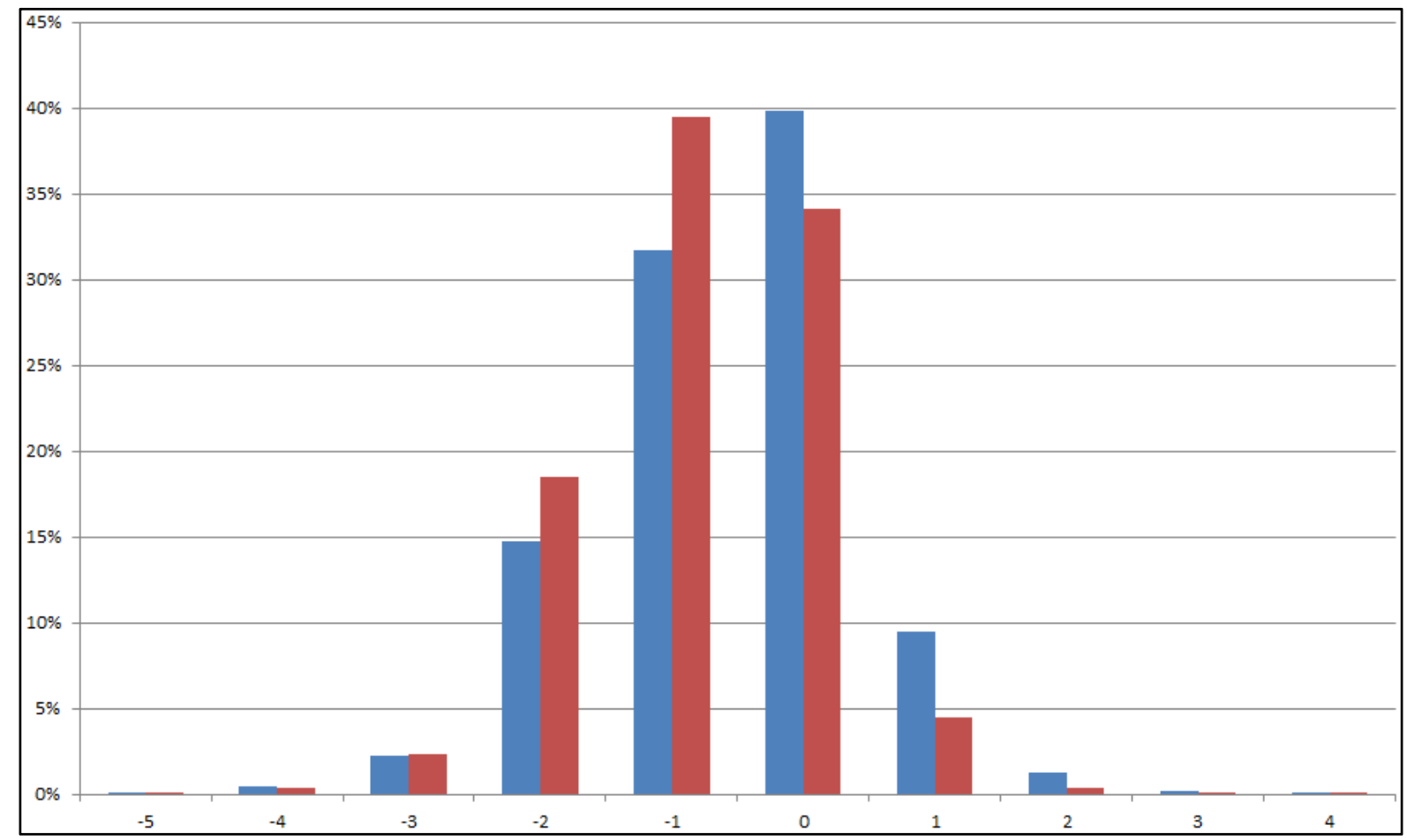


Figure 17. Percent of background hours (blue) and hours with bat passes (red) with (0) and without (1) precipitation at the Harkness weather station which is 20.1 kilometers to the southwest.

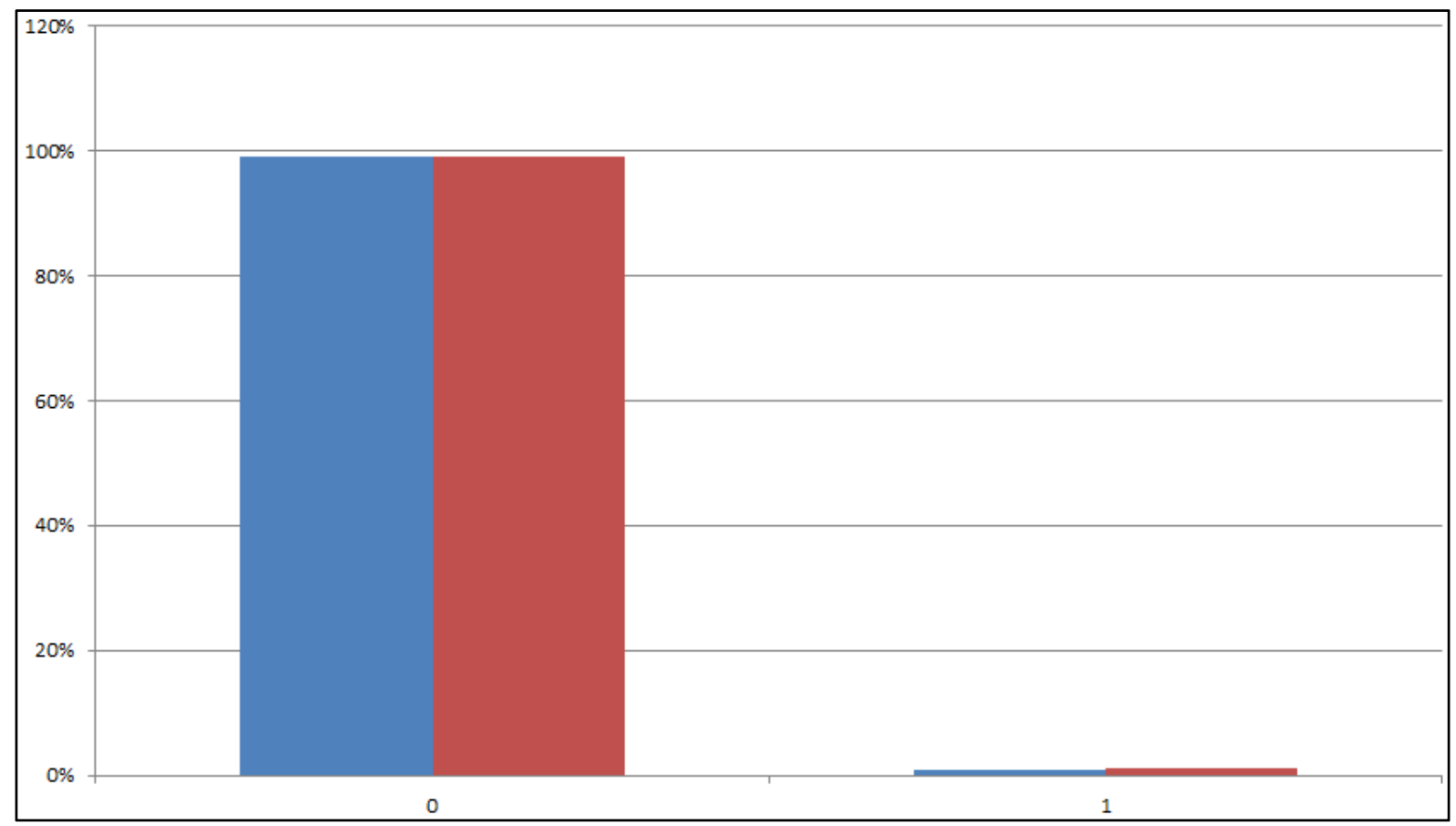


Figure 18. Percent of background hours (blue) and hours with bat passes (red) with (0) and without (1) precipitation across the regional network of detectors. Of the 467,512 hours that detectors have been deployed, precipitation data was available from nearby weather stations for 454,006 hours (97\%). Note that some detectors were up to 75 kilometers from the weather station where precipitation events were recorded $(X=30.0 \mathrm{~km}, \mathrm{SD}=14.2 \mathrm{~km})$ and bats are capable of flight within minutes of the passing of a rain shower.

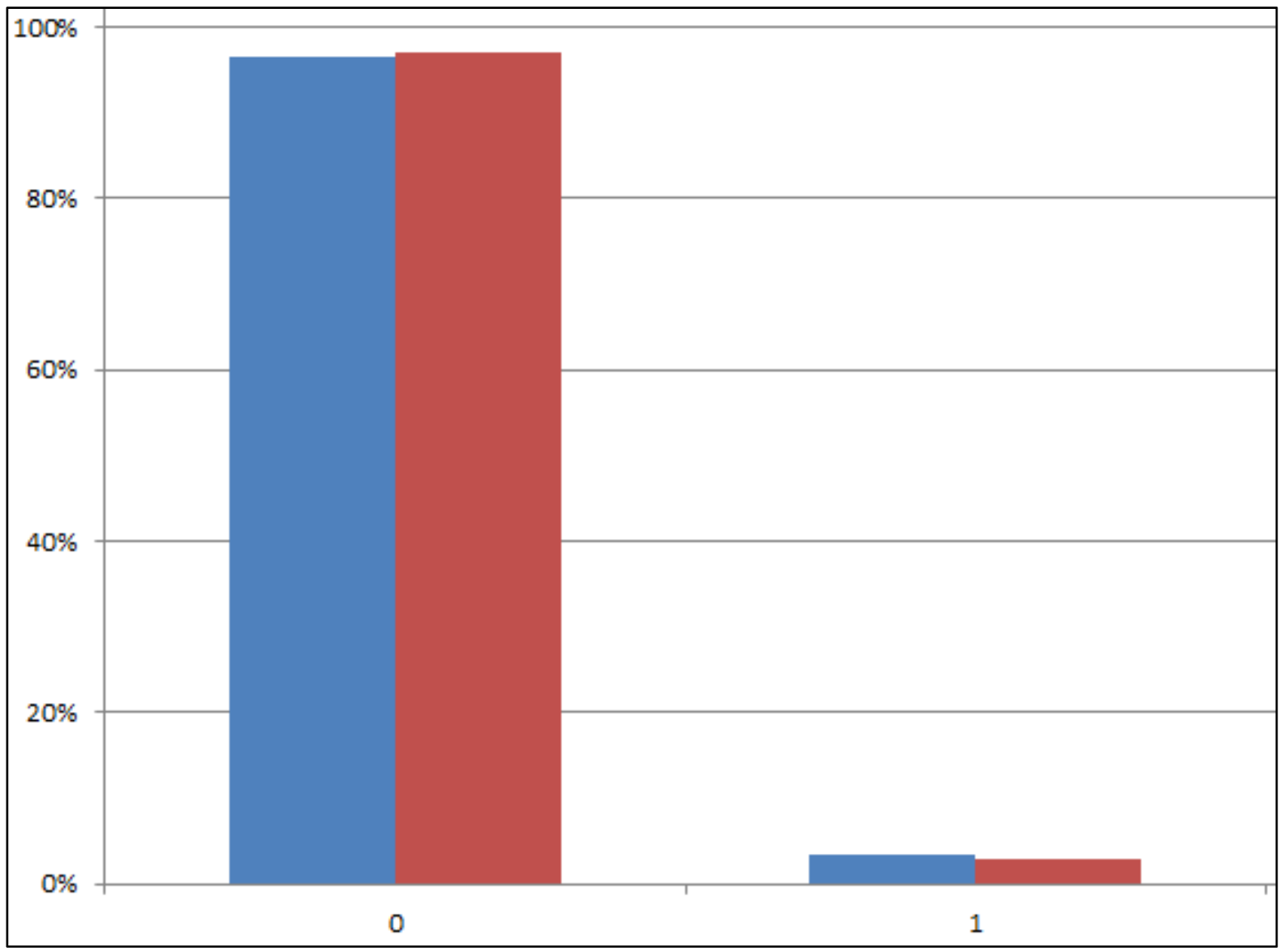


Figure 19. Percent of background hours (blue) and hours with bat passes (red) at various moon illumination categories ( $0=$ no illumination and $1=$ full moon) and with the moon above and below the horizon.

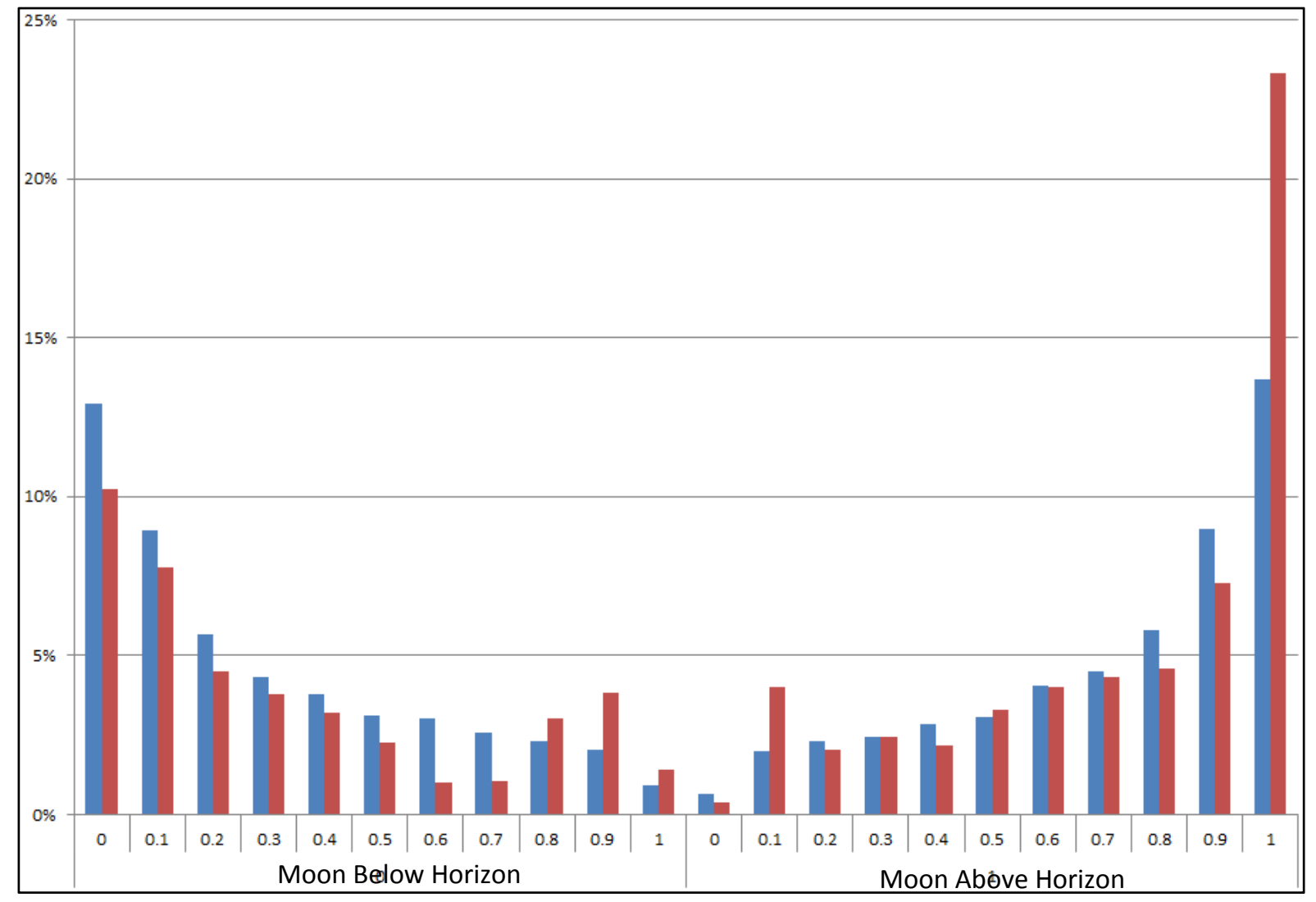


Figure 20. Percent of background hours (blue) and hours with bat passes (red) associated with various moon illumination categories ( $0=$ no illumination and $1=$ full moon) and with the moon below or above the horizon across the regional network of detectors. Moon illumination values were able to be calculated for $100 \%$ of the 467,512 hours that detectors have been deployed.

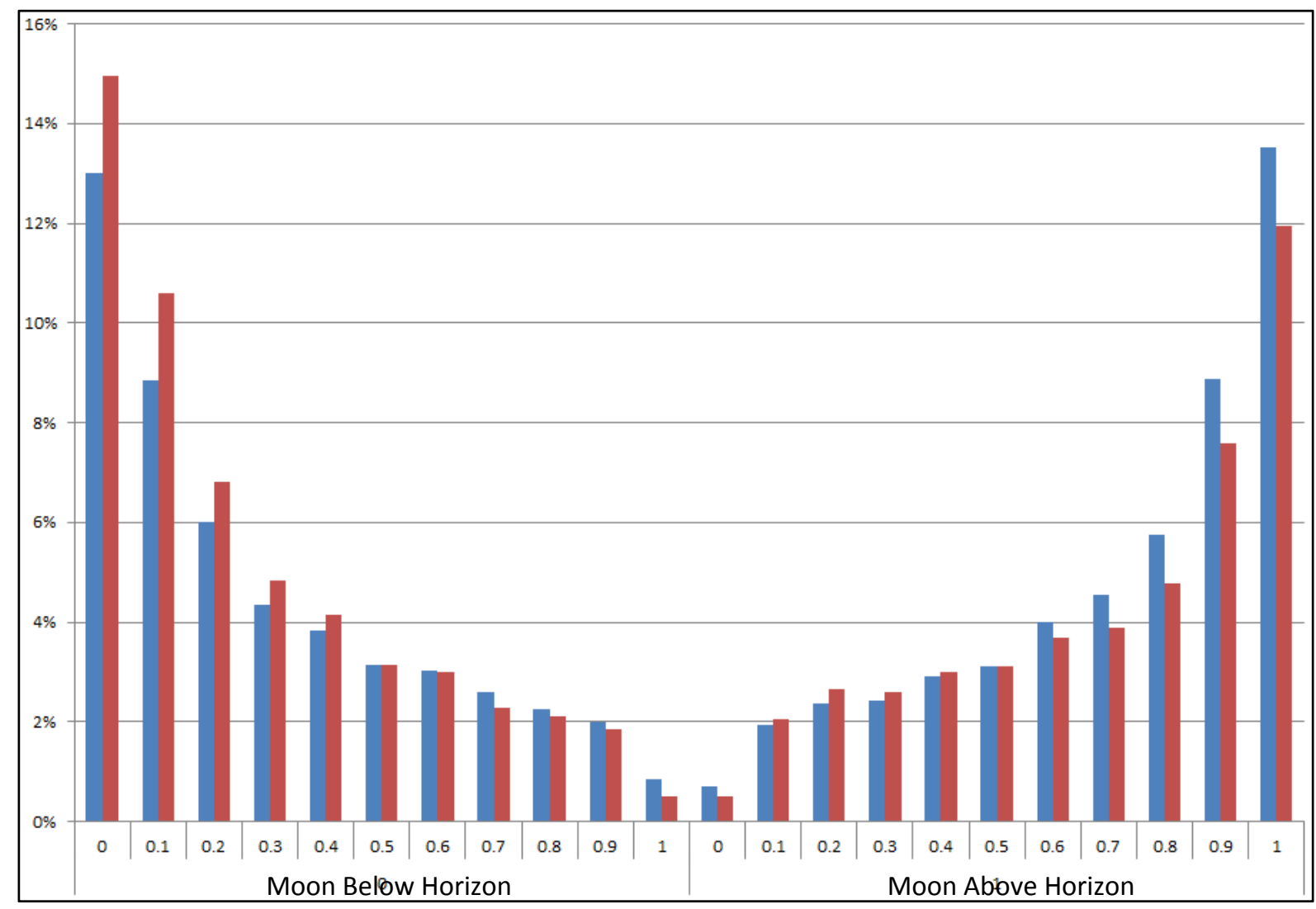


Figure 21. Average number of nightly bat passes each week auto-identified as Big Brown Bat. Numbers on $\mathrm{X}$ axis are years, months, and weeks.

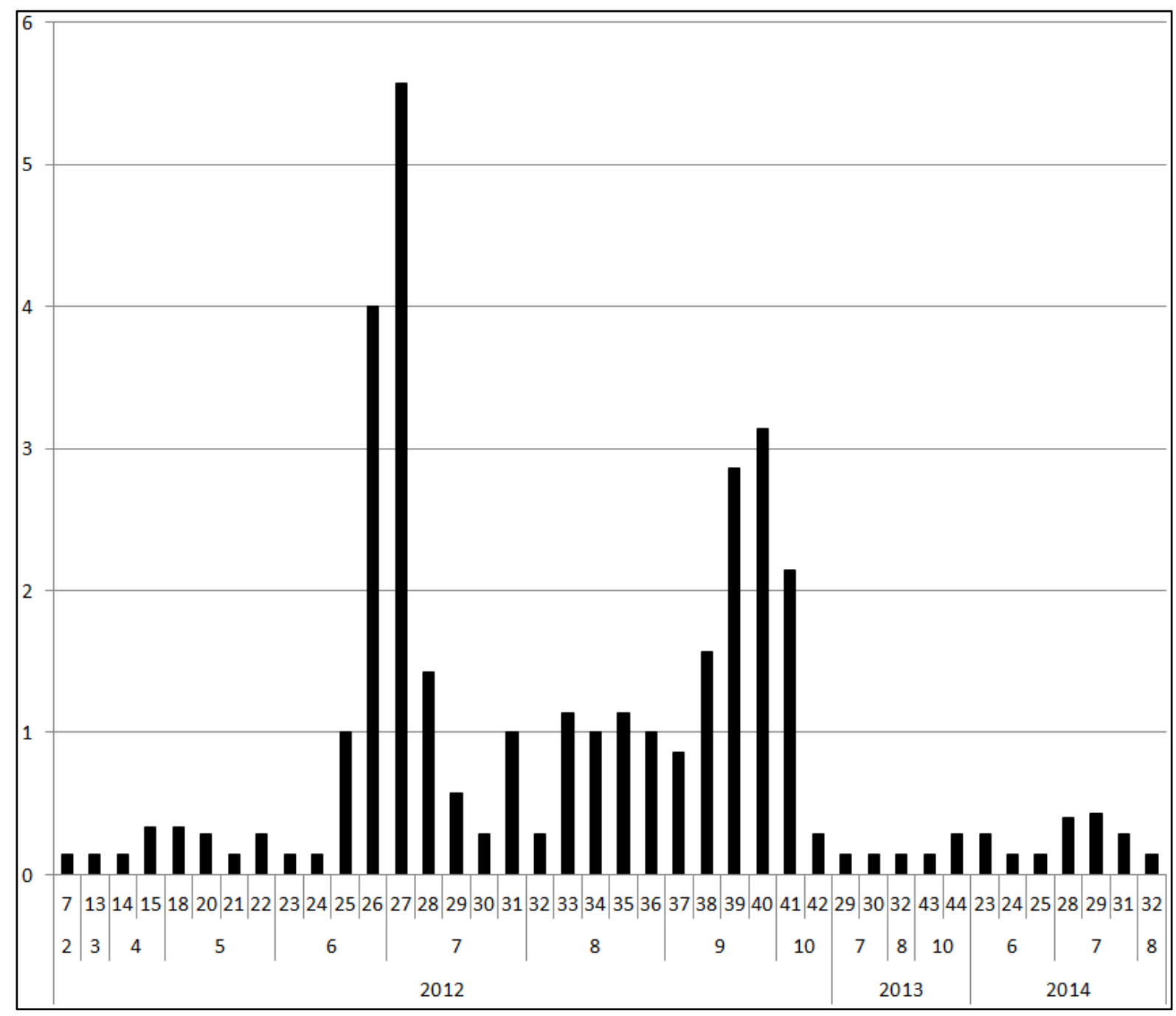


Figure 22. Average number of nightly bat passes each week auto-identified as Silver-haired Bat. Numbers on $\mathrm{X}$ axis are years, months, and weeks.

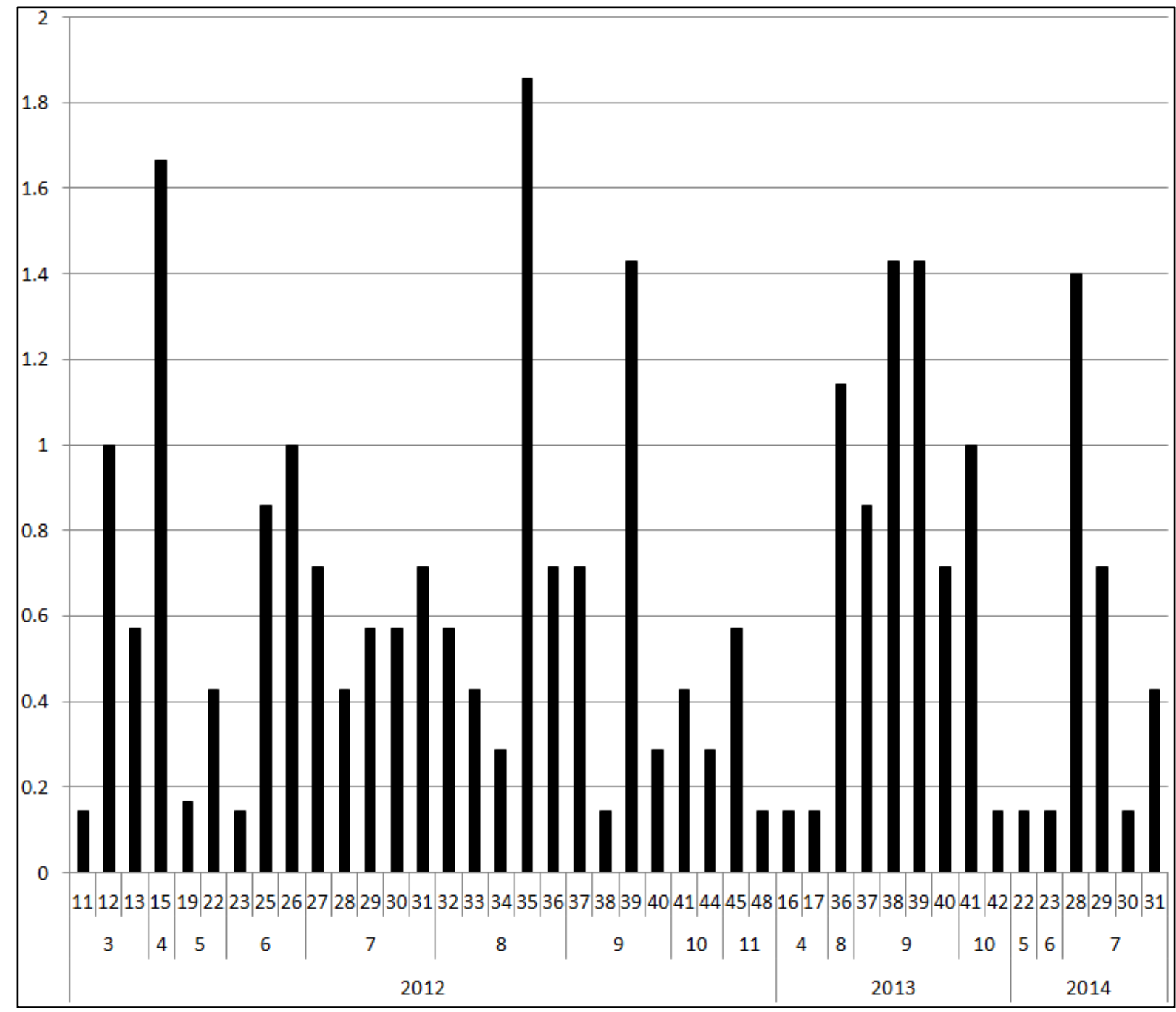


Figure 23. Average number of nightly bat passes each week auto-identified as Western Small-footed Myotis. Numbers on $\mathrm{X}$ axis are years, months, and weeks.

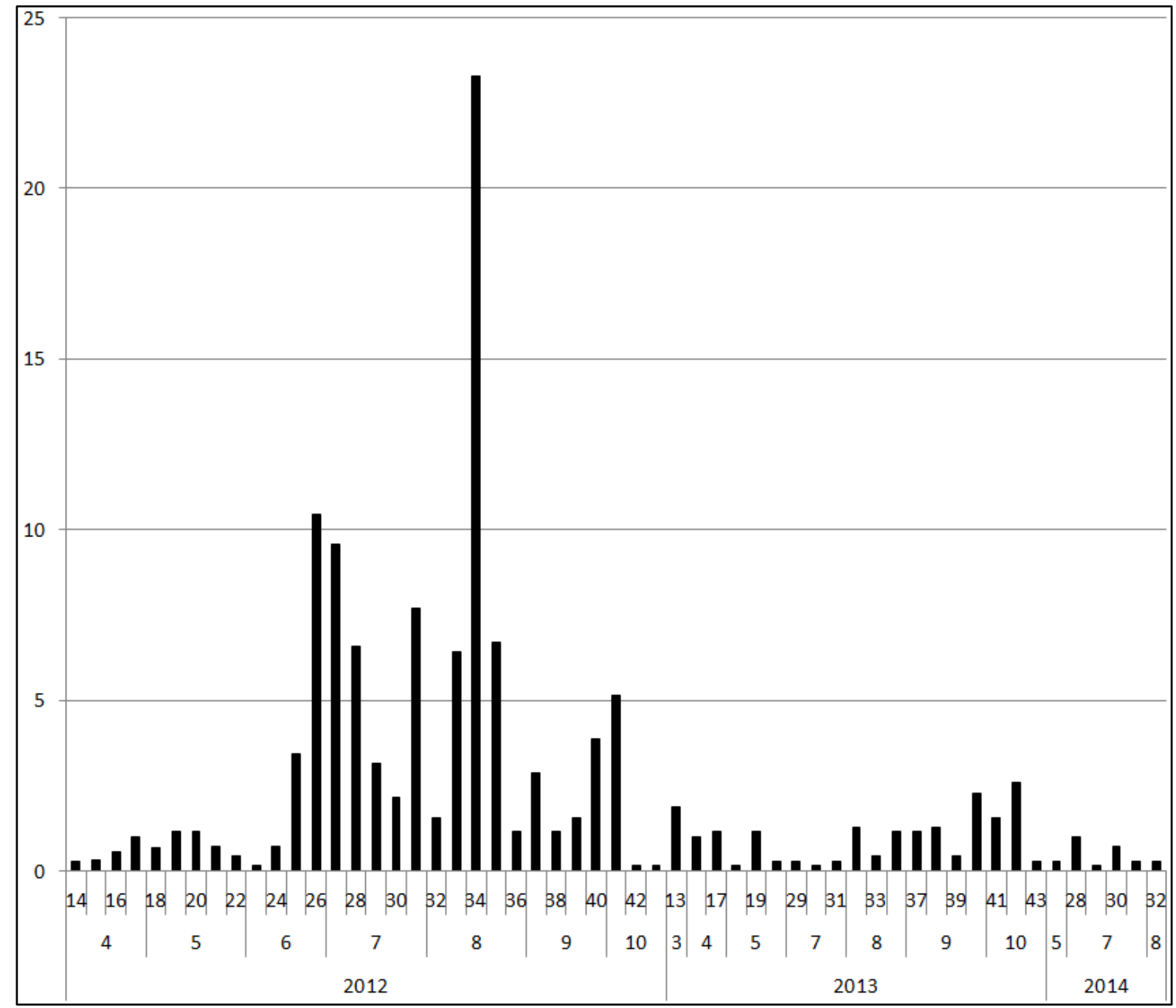


Figure 24. Average number of nightly bat passes each week auto-identified as Little Brown Myotis. Numbers on $\mathrm{X}$ axis are years, months, and weeks.

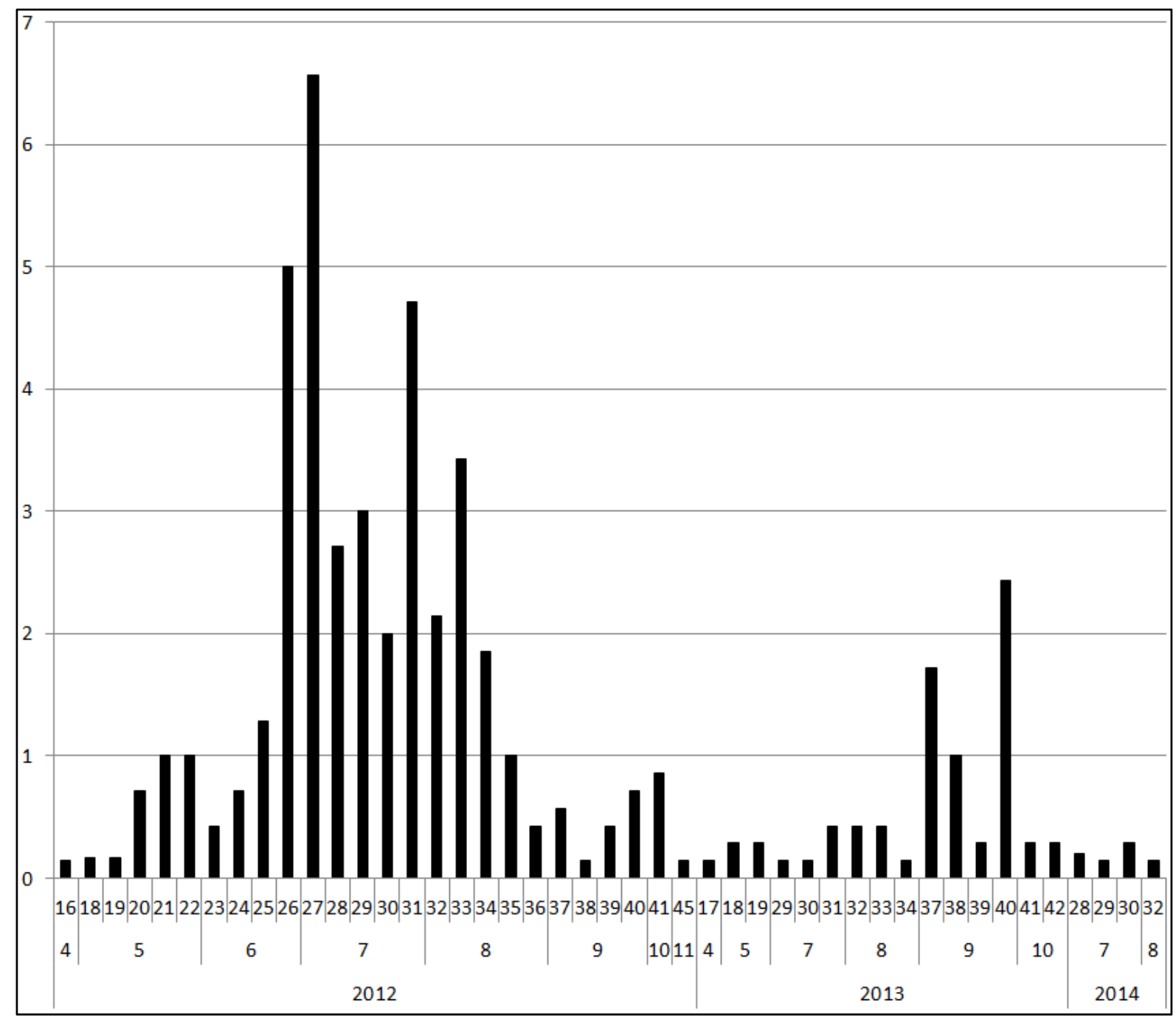




\title{
Appendix A
}

\section{References on Wind Turbine and other Human Structure Collision Impacts on Bats}

\author{
Compiled by Bryce A. Maxell, Senior Zoologist, Montana Natural Heritage Program
}

September 2015

An * in front of a citation, indicates the article has particular value for wind turbine impacts to bats and turbine management in Montana. Additional information on wind turbine impacts to bats and other wildlife can be found at the Wind-Wildlife Impacts Literature Database (WILD) at http://wild.nrel.gov

Ahlén, I. 2003. Wind turbines and bats-a pilot study. Uppsala, Sweden. http://publikationer.slu.se/Filer/08WindBat FinalReport.pdf

Anderson, R.L., D. Strickland, J. Tom, N. Neumann, W. Erickson, J. Cleckler, G. Mayorga, G. Nuhn, A. Leuders, J. Schneider, L. Backus, P. Becker and N. Flagg. 2000. Avian monitoring and risk assessment at Tehachapi Pass and San Gorgonio Pass wind resource areas, California: Phase 1 preliminary results. Proceedings of the National Avian-Wind Power Planning Meeting 3:31-46. National Wind Coordinating Committee, Washington, D.C.

Arnett, E. B. (Tech. ed.). 2005. Relationships between bats and wind turbines in Pennsylvania and West Virginia: An assessment of bat fatality search protocols, patterns of fatality, and behavioral interactions with wind turbines. A final report submitted to the Bats and Wind Energy Cooperative. Bat Conservation International.

*Arnett, E.B. 2006. A preliminary evaluation on the use of dogs to recover bat fatalities at wind energy facilities. Wildlife Society Bulletin 34(5):1440-1445.
*Arnett, E.B., W.K. Brown, W.P. Erickson, J.K. Fiedler, B.L. Hamilton, T.H. Henry, A. Jain, G.D. Johnson, J. Kerns, R.R. Koford, C.P. Nicholson, T.J. O'Connell, M.D. Piorkowski, and R.D. Tankersley, Jr. 2008. Patterns of bat fatalities at wind energy facilities in North America. Journal of Wildlife Management 72(1):61-78.

Arnett E.B., J.P. Hayes, M.M.P. Huso. 2006. An evaluation of the use of acoustic monitoring to predict bat fatality at a proposed wind facility in southcentral Pennsylvania. An annual report submitted to the bats and wind energy cooperative. Austin, Texas, USA. http://www.batsandwind.org/pdf/precon pa.pdf

*Arnett E.B., C. Hein, M. Schirmacher, M.M.P. Huso, and J. Szewczak. 2013. Evaluating the effectiveness of an ultrasonic acoustic deterrent for reducing bat fatalities at wind turbines. PLoS ONE 8(6):e65794.

doi:10.1371/journal.pone.0065794

Arnett, E.B., M.M.P. Huso, D.S. Reynolds, and M. Schirmacher. 2007. Patterns of preconstruction bat activity at a proposed wind facility in northwest Massachusetts. Annual report prepared for the Bats and Wind Energy Cooperative. Bat Conservation International. Austin, Texas, USA. 35 p. 
*Arnett, E.B., M.M.P. Huso, M.R. Schirmacher, and J.P. Hayes. 2011. Altering turbine speed reduces bat mortality at wind-energy facilities. Frontiers in Ecology and the Environment 9(4):209-214.

Avery, M. and T. Clement. 1972. Bird mortality at four towers in eastern North Dakota: Fall 1972. Prairie Naturalist 4:87-95.

*Baerwald, E.F. and R.M.R. Barclay. 2009. Geographic variation in activity and fatality of migratory bats at wind energy facilities. Journal of Mammalogy 90(6):1341-1349.

* Baerwald, E.F. and R.M.R. Barclay. 2011. Patterns of activity and fatality of migratory bats at a wind energy facility in Alberta, Canada. Journal of Wildlife Management 75(5):1103-1114.

Baerwald, E.F., G.H. D'Amours, B.J. Klug, and R.M.R. Barclay. 2008. Barotrauma is a significant cause of bat fatalities at wind turbines. Current Biology 18(16):R695R696.

*Baerwald, E.F., J. Edworthy, M. Holder, and R.M.R. Barclay. 2009. A large-scale mitigation experiment to reduce bat fatalities at wind energy facilities. Journal of Wildlife Management 73(7):1077-1081.

*Barclay, R.M.R., E.F. Baerwald, and J.C. Gruver. 2007. Variation in bat and bird fatalities at wind energy facilities: assessing the effects of rotor size and tower height. Canadian Journal of Zoology 85:381-387.

Bennett, V.J. and A.M. Hale. 2014. Red aviation lights on wind turbines do not increase bat-turbine collisions. Animal Conservation 17:354-358.

Bernardino, J., R. Bispo, H. Costa, and M. Mascarenhas. 2013. Estimating bird and bat fatality at wind farms: a practical overview of estimators, their assumptions and limitations. New Zealand Journal of Zoology 40(1):63-74.

Chang, T. E. Nielson, W. Auberle, F.I. Solop. 2013. A quantitative method to analyze the quality of EIA information in wind energy development and avian/bat assessments. Environmental Impact Assessment Review 38:142-150.

Crawford, R.L. and W.W. Baker. 1981. Bats killed at a north Florida television tower: a 25-year record. Journal of Mammalogy 62:651-652.

*Cryan, P.M. 2008. Mating behavior as a possible cause of bat fatalities at wind turbines. Journal of Wildlife Management 72(3): 845-849.

Cryan, P.M. and R.M.R. Barclay. 2009. Causes of bat fatalities at wind turbines: hypotheses and predictions. Journal of Mammalogy 90(6):1330-1340.

Cryan, P.M. and A.C. Brown. 2007. Migration of bats past a remote island offers clues toward the problem of bat fatalities at wind turbines. Biological Conservation 139:1-11.

*Cryan, P.M., P.M. Gorresen, C.D. Hein, M.R. Schirmacher, R.H. Diehl, M.M. Huso, D.T.S. Hayman, P.D. Fricker, F.J. Bonaccorso, D.H. Johnson, K. Heist, and D.C. Dalton. 2014. Behavior of bats at wind turbines. Proceedings of the National Academy of Sciences 111(42):15126-15131.

Cryan, P.M., J.W. Jameson, E.F. Baerwald, C.K.R. Willis, R.M.R. Barclay, E.A. Snider, and E.G. Chrichton. 2012. Evidence of latesummer mating readiness and early sexual maturation in migratory tree-roosting bats found dead at wind turbines. PLoS One 7(10):e47586. Doi:10.1371/journal.pone.0047586 
Cryan, P.M., C.A. Stricker, and M.B. Wunder. 2014. Continental-scale, seasonal movements of a heterothermic migratory tree bat. Ecological Applications 24(4):602616.

Cullinan, V.I., S. Matzner, and C.A. Duberstein. 2015. Classification of birds and bats using flight tracks. Ecological Informatics 27:5563.

DeBlase, A.F. and J.B. Cope. 1967. An Indiana bat impaled on barbed wire. American Midland Naturalist 77:238.

Dedon, M., S. Byrne, J. Aycrigg, and P. Hartman. 1989. Bird mortality in relation to the Mare Island 115-kV transmission line: progress report 1988/1989. Department of the Navy, Western Division, Naval Facilities Engineering Command, Office of Environmental Management, San Bruno, California. Report 443-89.3. 150pp.

Denys, G.A. 1972. Hoary bat impaled on barbed wire. Jack-Pine Warbler 50:63.

Diehl, R.H. 2013. The airspace is habitat. Trends in Ecology and Evolution 28(7):377379. doi.org/10.1016/j.tree.2013.02.015

Doty, A.C. and A.P. Martin. 2013. Assessment of bat and avian mortality at a pilot wind turbine at Coega, Port Elizabeth, Eastern Cape, South Africa. New Zealand Journal of Zoology 40(1):75-80.

*Drake, D., C.S. Jennelle, J.N. Liu, S.M. Grodsky, S. Schumacher, and M. Sponsler. 2015. Regional analysis of wind turbinecaused bat mortality. Acta Chiropterologica 17(1)179-188.

Erickson, W.P., B. Gritski, and K. Kronner, 2003. Nine Canyon Wind Power Project Avian and Bat Monitoring Annual Report. Technical report submitted to Energy
Northwest and the Nine Canyon Technical Advisory Committee.

Erickson, W.P., J. Jeffrey, K. Kronner, and K. Bay. 2003. Stateline Wind Project Wildlife Monitoring Annual Report, Results for the Period July 2001 - December 2002. Technical report submitted to FPL Energy, the Oregon Office of Energy, and the Stateline Technical Advisory Committee.

Erickson, W.P., G.D. Johnson, M.D. Strickland, and K. Kronner. 2000. Avian and bat mortality associated with the Vansycle Wind Project, Umatilla County, Oregon: 1999 study year. Technical Report prepared by WEST, Inc. for Umatilla County Department of Resource Services and Development, Pendleton, Oregon. 21p.

Erickson, W., G. Johnson, D. Young, D. Stickland, R. Good, M. Bourassa, K. Bay, K. Sernka. 2002. Synthesis and comparison of baseline avian and bat use, raptor nesting and mortality information from proposed and existing wind developments. Report to Bonneville Power Administration. West Inc., Cheyenne, Wyoming. $124 \mathrm{p}$.

Ferreira, D., C. Frexio, J.A. Cabral, R. Santos, and M. Santos. 2015. Do habitat characteristics determine mortality risk for bats at wind farms? Modelling susceptible species activity patterns and anticipating possible mortality events. Ecological Informatics 28:7-18.

Fiedler, J.K. 2004. Assessment of bat mortality and activity at Buffalo Mountain Windfarm, eastern Tennessee. M.S. Thesis, University of Tennessee, Knoxville.

Fiedler J.K., T.H. Henry, R.D. Tankersley, and C.P. Nicholson. 2007. Results of bat and bird mortality monitoring at the expanded Buffalo Mountain Windfarm, 2005. Tennessee Valley Authority. 
http://www.tva.gov/environment/bmw re port/results.pdf

Ganier, A.F. 1962. Bird casualties at a Nashville TV tower. Migrant 33:58-60.

Gollop, M.A. 1965. Bird migration collision casualties at Saskatoon. Blue Jay 23:15-17.

Grodsky, S.M., M.J. Behr, A. Gendler, D. Drake, B.D. Dieterle, R.J. Rudd, and N.L. Walrath. 2011. Investigating the causes of death for wind turbine-associated bat fatalities. Journal of Mammalogy 92(5):917925.

*Grodsky, S.M., C.S. Jennelle, D. Drake, T. Virzi. 2012. Bat mortality at a wind-energy facility in southeastern Wisconsin. Wildlife Society Bulletin 36(4):773-783.

Hayes, J.P. and D.L. Waldien. 2000. Potential influences of the proposed Condon Wind Project on bats. Unpublished report prepared for $\mathrm{CH} 2 \mathrm{MHILL}$, Portland, Oregon. $14 \mathrm{pp}$.

Hayes, J.P. and D.L. Waldien. 2000. Potential influences of the Stateline wind project on bats. Unpublished report prepared for CH2MHILL, Portland, Oregon.

*Hayes, M. 2013. Bats killed in large numbers at United States wind energy facilities. BioScience 63(12):975-979.

Higgins, K.F., R.G. Osborn, C.D. Dieter, and R.E. Usgaard. 1996. Monitoring of seasonal bird activity and mortality at the Buffalo Ridge Wind Resource Area, Minnesota, 1994-1995. Completion Report for the Research Period May 1, 1994 - December 31, 1995. Unpubl. report prepared for Kenetech Wind power, Inc. by the South Dakota Cooperative Fish and Wildlife Research Unit, Brookings, SD. 84pp.
*Horn, J.W., E.B. Arnett, and T.H. Kunz. 2008. Behavioral responses of bats to operating wind turbines. Journal of Wildlife Management 72(1):123-132.

Howe, R.W., W. Evans, and A.T. Wolf. 2002. Effects of wind turbines on birds and bats in northeastern Wisconsin. Wisconsin Public Service Corporation, Madison, Wisconsin

Howell, J.A. 1997. Bird mortality at rotor swept area equivalents, Altamont Pass and Montezuma Hills, California. Transactions of the Western Section of the Wildlife Society 33:24-29.

Howell, J.A. and J.E. Didonato. 1991. Assessment of avian use and mortality related to wind turbine operations, Altamont Pass, Alameda and Contra Costa Counties, California, September 1998 through August 1989. Final report submitted to U.S. Wind power, Inc.

Hull, C.L. and L. Cawthen. 2013. Bat fatalities at two wind farms in Tasmania, Australia: bat characteristics, and spatial and temporal patterns. New Zealand Journal of Zoology 40(1):5-15.

Huso, M.M.P. and D. Dalthrop. 2014. Accounting for unsearched areas in estimating wind turbine-caused fatality. Journal of Wildlife Management 78(2):347358.

Huso, M.M.P. and D. Dalthrop. 2014. A comment on "Bats killed in large numbers at United States wind energy facilities". BioScience 64(6):546-547.

James, R.D. 2002. Pickering Wind Turbine, Bird monitoring program in 2002. Report to Ontario Power Generation, December 2002.

Jameson, J.W. and C.K.R. Willis. 2012. Bat mortality at a wind power facility in central 
Canada. Northwestern Naturalist 93:194202.

*Jameson, J.W. and C.K.R. Willis. 2014. Activity of tree bats at anthropogenic tall structures: implications for mortality of bats at wind turbines. Animal Behaviour 97:145152.

Johnson, G.D. and E. Arnett. 2004. A bibliography of bat interactions with wind turbines. Unpublished. $9 \mathrm{p}$.

Johnson, G.D., W.P. Erickson, M.D. Strickland, M.F. Shepherd and D.A. Shepherd. 2000. Avian Monitoring Studies at the Buffalo Ridge Wind Resource Area, Minnesota: Results of a 4-year study. Technical report prepared for Northern States Power Co., Minneapolis, MN. 212pp.

Johnson, G.D., W.P. Erickson, M.D. Strickland, M.F. Shepherd, D.A. Shepherd, and S.A. Sarappo. 2003. Mortality of bats at a largescale wind power development at Buffalo Ridge, Minnesota. The American Midland Naturalist 150(2):332-342.

Johnson, G.D., W.P. Erickson, and J. White. 2003. Avian and bat mortality at the Klondike, Oregon Phase I Wind Plant. Technical report prepared for Northwestern Wind Power by WEST, Inc.

Johnson, G.D., M.K. Perlik, W.P. Erickson, and M.D. Strickland. 2004. Bat activity, composition, and collision mortality at large wind plant in Minnesota. Wildlife Society Bulletin 32(4):1278-1288.

Johnson, G.D., M.K. Perlik, W.P. Erickson, M.D. Strickland, D.A. Shepherd, and P. Sutherland, Jr. 2003. Bat interactions with wind turbines at the Buffalo Ridge, Minnesota Wind Resource Area: An assessment of bat activity, species composition, and collision mortality. Electric
Power Research Institute, Palo Alto, California, and Xcel Energy, Minneapolis, Minnesota. EPRI report \# 1009178.

Johnson, G.D. and M.D. Strickland. 2003. Biological assessment for the federally endangered Indiana bat (Myotis sodalis) and Virginia big-eared bat (Corynorhinus townsendii virginianus), NedPower Mount Storm Wind Project, Grant County, West Virginia. Unpublished report prepared by WEST, Inc. for NedPower Mount Storm, Chantilly, Virginia.

Johnson, G.D., D.P. Young, Jr., W.P. Erickson, M.D. Strickland, R.E. Good and P. Becker. 2000. Avian and bat mortality associated with the initial phase of the Foote Creek Rim Wind power Project, Carbon County, Wyoming: November 3, 1998 - October 31, 1999. Technical Report prepared for SeaWest Energy Corporation and Bureau of Land Management. 32pp.

Johnson, J.S., K.S. Watrous, G.J. Giumarro, T.S. Peterson, S.A. Boyden, and M.J. Lacki. 2011. Seasonal and geographic trends in acoustic detection of tree-roosting bats. Acta Chiropterologica 13(1):157-168.

Johnson, P.B. 1933. Accidents to bats. Journal of Mammalogy 14:156-157.

Keeley, B., S. Ugoretz, and D. Strickland. 2001. Bat ecology and wind turbine considerations. Proceedings of the National Avian-Wind Power Planning Meeting, 4:135-146. National Wind Coordinating Committee, Washington, D.C.

Kelm, D.H., J. Lenski, V. Kelm, U. Toelch, and F. Dziock. 2014. Seasonal bat activity in relation to distance to hedgerows in an agricultural landscape in central Europe and implications for wind energy development. 16(1):65-73. 
Kerlinger, P., R. Curry, and R. Ryder. 2000. Ponnequin wind energy project avian studies, Weld County, Colorado: Summary of activities during 2000. Prepared for Public Service Company of Colorado, Denver, Colorado.

Kiefer, A., H. Merz, W. Rackow, H. Roer, and D. Schlegel. 1995. Bats as traffic casualties in Germany. Myotis 32-33:215-220.

*Kiesecker, J.M., J.S. Evans, J. Fargione, K. Doherty, K.R. Foresman, T.H. Kunz, D. Naugle, N.P. Nibbelink, and N.D. Niemuth. 2011. Win-win for wind and wildlife: a vision to facilitate sustainable development. PLoS One 6:4:e17566.

Doi:10.1371/journal.pone.0017566.

Klug, B.J. and E.F. Baerwald. 2010. Incidence and management of live and injured bats at wind energy facilities. Journal of Wildlife Rehabilitation 30(2):11-16.

Koford, R., A. Jain, G. Zenner and A. Hancock. 2004. Avian mortality associated with the Top of lowa Wind Farm: Progress Report, Calendar Year 2003. lowa Cooperative Fish and Wildlife Research Unit, lowa State University, Ames, lowa. 9pp.

Korner-Nievergelt, F., P. Korner-Nievergelt, O. Behr, I. Niermann, R. Brinkmann, and B. Hellriegel. 2011. A new method to determine bird and bat fatality at wind energy turbines from carcass searches. Wildlife Biology 17:350-363.

Korstian, J.M., A.M. Hale, V.J. Bennett, and D.A. Williams. 2013. Advances in sex determination in bats and its utility in windwildlife studies. Molecular Ecology 13:776780.

Krenz, J.D., and B.R. McMillan. 2000. Final Report: Wind-turbine related bat mortality in southwestern Minnesota. Minnesota Department of Natural Resources, St. Paul.

*Kunz, T.H., E.B. Arnett, B.M. Cooper, W.P. Erickson, R.P. Larkin, T. Mabee, M.L. Morrison, M.D. Strickland, and J.M. Szewczak. 2007. Assessing impacts of wind-energy development on nocturnally active birds and bats: a guidance document. Journal of Wildlife Management 71(8):2449-2486.

*Kunz, T.H., E.B. Arnett, W.P. Erickson, A.R. Hoar, G.D. Johnson, R.P. Larkin, M.D. Strickland, R.W. Thresher, and M.D. Tuttle. 2007. Ecological impacts of wind energy development on bats: questions, research needs, and hypotheses. Frontiers in Ecology and the Environment 5(6):315-324.

Mabee, T.J., B.A. Cooper, and J.H. Plissner. 2004. A radar study of nocturnal bird migration at the proposed Mount Storm wind power development, West Virginia, Fall 2003. Unpublished report prepared by ABR, Inc. for WEST, Inc. and Nedpower.

*Mathews, F., M. Swindells, R. Goodhead, T.A. August, P. Hardman, D.M. Linton, D.J. Hosken. 2013. Effectiveness of search dogs compared with human observers in locating bat carcasses at wind-turbine sites: a blinded randomized trial. Wildlife Society Bulletin 37(1):34-40.

Millon, L., J.F. Julen, R. Julliard, and C. Kerbiriou. 2015. Bat activity in intensively farmed landscapes with wind turbines and offset measures. Ecological Engineering 75:250-257.

*Minderman, J., C.J. Pendlebury, J.W. PearceHiggins, and K.J. Park. 2012. Experimental evidence for the effect of small wind turbine proximity and operation on bird and bat activity. PLoS One 7(7):e41177. Doi:10.1371/journal.pone.0041177. 
Nicholson, C.P. 2003. Buffalo Mountain Windfarm bird and bat mortality monitoring report: October 2001 - September 2002. Tennessee Valley Authority, Knoxville.

Nicholson, C.P. 2001. Buffalo Mountain Windfarm bird and bat mortality monitoring report: October 2000 - September 2001. Tennessee Valley Authority, Knoxville.

Orloff, S. and A. Flannery. 1992. Wind turbine effects on avian activity, habitat use, and mortality in Altamont Pass and Solano County Wind Resource Areas, 1989-1991. Final report to Alameda, Costra Costa and Solano Counties and the California Energy Commission by Biosystems Analysis, Inc., Tiburon, CA.

Osborn, R.G., K.F. Higgins, C.D. Dieter, and R.E. Usgaard. 1996. Bat collisions with wind turbines in southwestern Minnesota. Bat Research News 37:105-108.

Pandion Systems, Inc. 2003. White paper on bats and wind turbines with reference to the Backbone Mountain site. Unpublished report prepared for Florida Power \& Light, Juno Beach, Florida.

Péron, G., J.E. Hines, J.D. Nichols, W.L. Kendall, K.A. Peters, and D.S. Misrahi. 2013. Estimation of bird and bat mortality at wind-power farms with superpopulation models. Journal of Applied Ecology 50:902911.

Peste, F., A. Paula, L.P. da Silva, J. Bernardino, P. Pereira, M. Mascarenhas, H. Costa, J. Vieira, C. Bastos, C. Fonseca, M.J.R. Pereira. 2015. How to mitigate impacts of wind farms on bats? A review of potential conservation measures in the European context. Environmental Impact Assessment Review 51:10-22.
Piorkowski, M.D. and T.J. O'Connell. 2010. Spatial pattern of summer bat mortality from collisions with wind turbines in mixedgrass prairie. American Midland Naturalist 164(2):260-269.

Poulton, V. and W. Erickson. 2010. Postconstruction bat and bird fatality study Judith Gap Wind Farm Wheatland County, Montana. Final Report. Results from JuneOctober 2009 study and comparison with 2006-2007 study. Western Ecosystems Technology, Inc. 2003 Central Avenue, Cheyenne, WY. 35 p.

Puzen, S.C. 2002. Bat interactions with wind turbines in northeastern Wisconsin. Wisconsin Public Service Commission, Madison, Wisconsin.

Redell D., E.B. Arnett, J.P. Hayes, M.M.P. Huso. 2006. Patterns of preconstruction bat activity determined using acoustic monitoring at a proposed wind facility in south-central Wisconsin. A final report submitted to the Bats and Wind Energy Cooperative. Bat Conservation International. Austin, Texas, USA. http://www.batsandwind.org/pdf/precon wi.pdf

Reynolds, D.S. 2006. Monitoring the potential impact of a wind development site on bats in the northeast. Journal of Wildlife Management 70(5):1219-1227.

*Rollins, K.E., D.K. Meyerholz, G.D. Johnson, A.P. Capparella, and S.S. Loew. 2012. A forensic investigation into the etiology of bat mortality at a wind farm: barotrauma or traumatic injury? Veterinary Pathology 49(2):362-371.

Rocioni, F., H. Rebelo, D. Russo, M.L. Carranza, M.D. Febbraro, and A. Loy. 2014. A modelling approach to infer the effects of 
wind farms on landscape connectivity for bats. Landscape Ecology 29:891-903.

Rydell J., L. Bach, M. Dubourg-Savage, M. Green, L. Rodrigues, and A. Hedenström. 2010. Bat mortality at wind turbines in northwestern Europe. Acta Chiropterologica 12(2):261-274. doi:10.3161/150811010X537846

Rydell, J., L. Bach, M. Dubourg-Savage, M. Green, L. Rodrigues, and A. Hedenstrom. 2010. Mortality of bats at wind turbines links to nocturnal insect migration. European Journal of Wildlife Research 56:823-827.

Saunders, W.E. 1930. Bats in migration. Journal of Mammalogy 11:225.

Schmidt, E., A.J. Piaggio, C.E. Bock, and D.M. Armstrong. 2003. National Wind Technology Center site environmental assessment: bird and bat use and fatalities Final report NREL/SR-500-32981, National Renewable Energy Laboratory, Golden, Colorado. 21pp.

*Schuster, E., L. Bulling, and J. Koppel. 2015. Consolidating the state of knowledge: a synoptical review of wind energy's wildlife effects. Environmental Management 56:300-331.

Sjollema, A.L., J.E. Gats, R.H. Hilderbrand, and J. Sherwell. 2014. Offshore activity of bats along the mid-Atlantic Coast. Northeastern Naturalist 21(2):154-163.

Smallwood, K.S. 2013. Comparing bird and bat fatality-rate estimates among North American wind-energy projects. Wildlife Society Bulletin 37(1):19-33.

Smallwood, K.S., D.A. Bell, S.A. Snyder, and J.E. Didonato. 2010. Novel scavenger removal trials increase wind turbine-caused avian fatality estimates. Journal of Wildlife Management 74(5):1089-1097.

Smallwood, K.S. and B. Karas. 2009. Avian and bat fatality rates at old-generation and repowered wind turbines in California. Journal of Wildlife Management 73(7):1062-1071.

Tennessee Valley Authority. 2002. Draft Environmental Assessment - 20-MW Windfarm and Associated Energy Storage Facility. Tennessee Valley Authority, Knoxville, Tennessee.

Terres, J.K. 1956. Migration records of the red bat, Lasiurus borealis. Journal of Mammalogy 37:442.

Thelander, C.G. and L. Rugge. 2000. Bird risk behaviors and fatalities at the Altamont Wind Resource Area. Pp. 5-14 in Proceedings of the National Avian-Wind Power Planning Meeting III. National Wind Coordinating Committee/RESOLVE. Washington, D.C.

Tuttle, M.D. 2004. Wind energy and the threat to bats. BATS 22(2):4-5.

U.S. Department of Energy. 2002. Draft SiteWide Environmental Assessment of National Renewable Energy Laboratory's National Wind Technology Center. U.S. Department of Energy, Golden, Colorado.

Van Gelder, R.G. 1956. Echo-location failure in migratory bats. Transactions of the Kansas Academy of Science 59:220-222.

Villegas-Patraca, R., S. Macias-Sanchez, I. MacGregor-Fors, and C. Munoz-Robles. 2012. Scavenger removal: bird and bat carcass persistence in a tropical wind farm. Acta Oecologica 43:121-125. 
Voigt, C.C., L.S. Lehnert, G. Petersons, F. Adorf, and L. Bach. 2015. Wildlife and renewable energy: German politics cross migratory bats. European Journal of Wildlife Research 61:213-219.

*Voigt, C.C., A.G. Popa-Lisseanu, I. Niermann, and S. Kramer-Schadt. 2012. The catchment area of wind farms for European bats: a plea for international regulations. Biological Conservation 153:80-86.

*Weller, T.J. and J.A. Baldwin. 2012. Using echolocation monitoring to model bat occupancy and inform mitigations at wind energy facilities. Journal of Wildlife Management 76(3):619-631.

Williams, W. 2004. When blade meets bat: Unexpected bat kills threaten future wind farms. Scientific American. February 2004.

Williams, W. 2003. Alarming evidence of bat kills in eastern U.S. Windpower Monthly 19: 21-23.

Winhold, L., A. Kurta, and R. Foster. 2008. Long-term change in an assemblage of
North American bats: are eastern red bats declining? Acta Chiropterologica 10(2):359366.

Wisely, A.N. 1978. Bat dies on barbed wire fence. Blue Jay 36:53.

Wolbert, S.J., A.S. Zellner, H.P. Whidden. 2014. Bat activity, insect biomass, and temperature along an elevational gradient. Northeastern Naturalist 21(1):72-85.

Young, D.P., Jr., W.P. Erickson, R.E. Good, M.D. Strickland, and G.D. Johnson. 2003. Avian and bat mortality associated with the initial phase of the Foote Creek Rim wind power project, Carbon County, Wyoming: November 1998 - June 2002. Tech. Rept. prepared for SeaWest Energy Corporation and Bureau of Land Management.

Young, D.P., Jr., W.P. Erickson, M.D. Strickland, and R.E. Good. 2002. Comparison of avian effects from UV light reflective paint applied to wind turbines: Foote Creek Rim Wind Plant, Carbon County, Wyoming. National Renewable Energy Laboratory, Golden, Colorado. 


\section{Appendix B}

Bat Pass Temperatures Summarized by Species and Month for Big Sheep Creek ${ }^{1}$

\begin{tabular}{|c|c|c|c|c|c|}
\hline Species $^{2}$ & Year & Month & $\begin{array}{c}\text { Bat Pass Temp C } \\
\text { Avg (SD) N }\end{array}$ & $\begin{array}{c}\text { Bat Pass } \\
\text { Min Temp C }\end{array}$ & $\begin{array}{c}\text { Bat Pass } \\
\text { Max Temp C }\end{array}$ \\
\hline Epfu & 2012 & 2 & $0.6\left(^{3}\right) 1$ & 0.6 & 0.6 \\
\hline Epfu & 2012 & 3 & $11.7\left(^{3}\right) 1$ & 11.7 & 11.7 \\
\hline Epfu & 2012 & 4 & $6.3(3) 3$ & 3.6 & 9.5 \\
\hline Epfu & 2012 & 5 & $16.6(2.7) 4$ & 14.3 & 20.1 \\
\hline Epfu & 2012 & 6 & $15.2(3.5) 38$ & 8.7 & 21.7 \\
\hline Epfu & 2012 & 7 & $18.3(2.5) 56$ & 9.7 & 23.6 \\
\hline Epfu & 2012 & 8 & $17.7(2.5) 31$ & 11.7 & 21.4 \\
\hline Epfu & 2012 & 9 & $17.4(1.6) 50$ & 15.5 & 21.9 \\
\hline Epfu & 2012 & 10 & $16.1(1.2) 33$ & 13.3 & 17.4 \\
\hline Epfu & 2013 & 7 & $20.9(0.8) 2$ & 20.3 & 21.4 \\
\hline Epfu & 2013 & 8 & $15.6\left(^{3}\right) 1$ & 15.6 & 15.6 \\
\hline Epfu & 2013 & 10 & $3.1(1.3) 2$ & 2.2 & 4.1 \\
\hline Epfu & 2013 & 11 & $2.4\left(^{3}\right) 1$ & 2.4 & 2.4 \\
\hline Epfu & 2014 & 6 & $16.2(3) 4$ & 14.3 & 20.6 \\
\hline Epfu & 2014 & 7 & $17.2(4.7) 6$ & 9.4 & 22.1 \\
\hline Epfu & 2014 & 8 & $14.9(5.6) 2$ & 11 & 18.9 \\
\hline Laci & 2012 & 7 & $17.8(0.9) 3$ & 16.8 & 18.4 \\
\hline Laci & 2012 & 8 & $21.3(5.9) 2$ & 17.1 & 25.4 \\
\hline Laci & 2012 & 9 & $13.2\left(^{3}\right) 1$ & 13.2 & 13.2 \\
\hline Laci & 2013 & 8 & $19.9\left(^{3}\right) 1$ & 19.9 & 19.9 \\
\hline Laci & 2013 & 9 & $13.3(8.1) 5$ & 4.4 & 20.1 \\
\hline Laci & 2013 & 10 & $5.2\left({ }^{3}\right) 1$ & 5.2 & 5.2 \\
\hline Laci & 2014 & 7 & $15.6\left(^{3}\right) 1$ & 15.6 & 15.6 \\
\hline Laci & 2014 & 8 & $16.7(1.3) 2$ & 15.8 & 17.6 \\
\hline Lano & 2012 & 3 & $8.2(1.4) 12$ & 5.7 & 9.8 \\
\hline Lano & 2012 & 4 & $6.3(2) 9$ & 5.4 & 11.7 \\
\hline Lano & 2012 & 5 & $12.5(3.5) 2$ & 10 & 15 \\
\hline Lano & 2012 & 6 & $15.1(4.8) 15$ & 8.4 & 23.4 \\
\hline Lano & 2012 & 7 & $17(3.4) 17$ & 8 & 21.4 \\
\hline Lano & 2012 & 8 & $17.2(4.3) 26$ & 9.8 & 23.6 \\
\hline Lano & 2012 & 9 & $17(2.8) 23$ & 10.3 & 21.9 \\
\hline Lano & 2012 & 10 & $10.1(3.9) 5$ & 4.4 & 15.1 \\
\hline Lano & 2012 & 11 & $7.6(2.7) 5$ & 4.7 & 11 \\
\hline Lano & 2013 & 4 & $7.8(2) 2$ & 6.4 & 9.2 \\
\hline
\end{tabular}

B-1 


\begin{tabular}{|c|c|c|c|c|c|}
\hline Species $^{2}$ & Year & Month & $\begin{array}{c}\text { Bat Pass Temp C } \\
\text { Avg (SD) N }\end{array}$ & $\begin{array}{c}\text { Bat Pass } \\
\text { Min Temp C }\end{array}$ & $\begin{array}{c}\text { Bat Pass } \\
\text { Max Temp C }\end{array}$ \\
\hline Lano & 2013 & 9 & $13.4(5.2) 34$ & 4.7 & 20.8 \\
\hline Lano & 2013 & 10 & $8.3(2.2) 13$ & 3.1 & 11.7 \\
\hline Lano & 2014 & 5 & $19.1\left(^{3}\right) 1$ & 19.1 & 19.1 \\
\hline Lano & 2014 & 6 & $15\left(^{3}\right) 1$ & 15 & 15 \\
\hline Lano & 2014 & 7 & $17.8(4.1) 14$ & 8.5 & 22.2 \\
\hline Lano & 2014 & 8 & $19.6(3.7) 2$ & 17 & 22.2 \\
\hline Myci & 2012 & 4 & $7.2(1.1) 2$ & 6.4 & 8 \\
\hline Myci & 2012 & 5 & $14.7(4.4) 20$ & 6.5 & 20.1 \\
\hline Myci & 2012 & 6 & $17.1(3.7) 103$ & 6.2 & 23.2 \\
\hline Myci & 2012 & 7 & $18.4(3.3) 173$ & 7.5 & 24.4 \\
\hline Myci & 2012 & 8 & $14.2(3.6) 297$ & 7.4 & 25.9 \\
\hline Myci & 2012 & 9 & $16.6(2.2) 58$ & 12.3 & 20.4 \\
\hline Myci & 2012 & 10 & $12.1(3.2) 53$ & 4.7 & 17.4 \\
\hline Myci & 2012 & 11 & $6.4\left(^{3}\right) 1$ & 6.4 & 6.4 \\
\hline Myci & 2013 & 3 & $7.3(0.2) 13$ & 7 & 8 \\
\hline Myci & 2013 & 4 & $8.9(2.6) 15$ & 5.5 & 14.5 \\
\hline Myci & 2013 & 5 & $13.2(2.2) 11$ & 9 & 16 \\
\hline Myci & 2013 & 7 & $21(1.5) 4$ & 19.8 & 22.9 \\
\hline Myci & 2013 & 8 & $19.3(3.7) 21$ & 11 & 24.1 \\
\hline Myci & 2013 & 9 & $14.5(4.2) 20$ & 7 & 21.6 \\
\hline Myci & 2013 & 10 & $10.7(2.2) 47$ & 6.7 & 13.5 \\
\hline Myci & 2014 & 5 & $17.1(0.9) 2$ & 16.5 & 17.8 \\
\hline Myci & 2014 & 7 & $19.2(3.2) 11$ & 14.8 & 22.7 \\
\hline Myci & 2014 & 8 & $20.5(0.8) 4$ & 19.9 & 21.7 \\
\hline Myev & 2012 & 5 & $14.5(3.3) 3$ & 12 & 18.3 \\
\hline Myev & 2012 & 6 & $15.7(5.2) 9$ & 8.9 & 22.7 \\
\hline Myev & 2012 & 7 & $14.7(4.3) 8$ & 8 & 19.8 \\
\hline Myev & 2012 & 8 & $16.8(1.9) 4$ & 15 & 19.1 \\
\hline Myev & 2012 & 9 & $11\left(^{3}\right) 1$ & 11 & 11 \\
\hline Myev & 2012 & 10 & $10.3\left(^{3}\right) 1$ & 10.3 & 10.3 \\
\hline Myev & 2013 & 5 & $12(7.5) 2$ & 6.7 & 17.3 \\
\hline Myev & 2013 & 6 & $10.2\left(^{3}\right) 1$ & 10.2 & 10.2 \\
\hline Myev & 2013 & 7 & $19.8(4) 3$ & 15.3 & 22.9 \\
\hline Myev & 2013 & 8 & $15(6) 3$ & 8.2 & 19.4 \\
\hline Myev & 2014 & 5 & $12.3(5) 2$ & 8.7 & 15.8 \\
\hline Myev & 2014 & 6 & $10.8(4.7) 3$ & 5.7 & 15 \\
\hline Myev & 2014 & 7 & $17.9(2.7) 5$ & 13.8 & 21.1 \\
\hline Myev & 2014 & 8 & $18.4(2.1) 2$ & 17 & 19.9 \\
\hline
\end{tabular}




\begin{tabular}{|c|c|c|c|c|c|}
\hline Species $^{2}$ & Year & Month & $\begin{array}{c}\text { Bat Pass Temp C } \\
\text { Avg (SD) N }\end{array}$ & $\begin{array}{c}\text { Bat Pass } \\
\text { Min Temp C }\end{array}$ & $\begin{array}{c}\text { Bat Pass } \\
\text { Max Temp C }\end{array}$ \\
\hline Mylu & 2012 & 5 & $13.4(3.7) 17$ & 3.9 & 17.6 \\
\hline Mylu & 2012 & 6 & $16.4(4.8) 54$ & 6.7 & 23.4 \\
\hline Mylu & 2012 & 7 & $17.6(3.4) 110$ & 8 & 23.9 \\
\hline Mylu & 2012 & 8 & $17.7(3.7) 82$ & 7.7 & 26 \\
\hline Mylu & 2012 & 9 & $14.2(4.3) 14$ & 4.2 & 19.8 \\
\hline Mylu & 2012 & 10 & $12.2(2.7) 8$ & 9.7 & 16.1 \\
\hline Mylu & 2012 & 11 & $9.8\left(^{3}\right) 1$ & 9.8 & 9.8 \\
\hline Mylu & 2013 & 4 & $14.5\left(^{3}\right) 1$ & 14.5 & 14.5 \\
\hline Mylu & 2013 & 5 & $11.8(2.8) 4$ & 8.5 & 15.1 \\
\hline Mylu & 2013 & 7 & $16.9(6.4) 4$ & 9.2 & 22.9 \\
\hline Mylu & 2013 & 8 & $21(2.7) 8$ & 15.6 & 25.2 \\
\hline Mylu & 2013 & 9 & $18.5(3.5) 21$ & 11 & 21.7 \\
\hline Mylu & 2013 & 10 & $11.6(2.3) 21$ & 7.5 & 13.5 \\
\hline Mylu & 2014 & 7 & $19.6(3) 4$ & 15.5 & 22.7 \\
\hline Mylu & 2014 & 8 & $19.9\left(^{3}\right) 1$ & 19.9 & 19.9 \\
\hline
\end{tabular}

1 Only records auto-identified to species and able to be associated with temperatures are included and only species with auto identification accuracies from Sonobat 3.0 evaluated through manual review as greater than $50 \%$ are included.

2 Species codes are the first two letters of the genus and species names.

3 Cannot calculate standard deviation with a single value. 


\section{Appendix C}

\section{Overview of Roosting Habitat and Home Range / Foraging Distance Documented for Montana Bats}

Bryce A. Maxell, Montana Natural Heritage Program - 24 February 2015

The table, figures, and images below summarize and provide examples of what is known about winter, maternity, and day/night roost habitat use for Montana bat species in the state and/or elsewhere across their ranges. Protection of these cave, mine, cliff, rock outcrop, ground crevice, large tree, bridge, and building habitats with cracks and crevices ranging from $1 / 3$ to 1 inch in width and associated temperature and humidity regimes, is essential for protection and conservation of Montana's bats. Artificial bat roosts that provide summer maternity, night, and day roosts, can be deployed to serve as a surrogate for large diameter tree and other roosts that have been lost and/or to encourage roosting away from buildings where bats would be in close proximity to sleeping humans. Artificial winter roost habitat is not a viable management option at the present time.

\begin{tabular}{|c|c|c|c|c|}
\hline Species / Comments & Winter Roost & Summer Maternity Roost & Summer Day/Night Roost & Home Range/Foraging Distance \\
\hline $\begin{array}{l}\text { Pallid Bat } \\
\text { (Antrozous pallidus) } \\
\text { Low roost site fidelity with } 90 \% \\
\text { of inter-night movements of } 50- \\
600 \text { meters. }{ }^{3} \text { Highly social, } \\
\text { often using day and night roosts } \\
\text { in groups of } 20 \text { or more guided } \\
\text { by social vocalizations and } \\
\text { odors. }{ }^{2,4} \text { Yearling females } \\
\text { typically give birth to a single } \\
\text { pup, but older females typically } \\
\text { give birth to } 2 \text { pups. }{ }^{4,43}\end{array}$ & $\begin{array}{l}\text { Not documented in Montana, } \\
\text { but likely occurs in deep rock } \\
\text { crevices if the species is } \\
\text { present. }^{1,4}\end{array}$ & $\begin{array}{l}\text { Not documented in Montana. } \\
\text { Elsewhere in vertical and } \\
\text { horizontal rock crevices, } \\
\text { under rock slabs, in buildings, } \\
\text { and on taller and larger } \\
\text { diameter live trees and tree } \\
\text { snags with loose bark in } \\
\text { mature stands with southerly } \\
\text { aspects and lower } \\
\text { percentages of overstory. } 4,37, \\
38,41,42,44\end{array}$ & $\begin{array}{l}\text { Under rock slabs, in horizontal } \\
\text { and vertical rock crevices, and } \\
\text { on farm equipment in } \\
\text { Montana. }{ }^{1} \text { Elsewhere } \\
\text { occasionally on buildings, } \\
\text { bridges, caves, mines, vertical } \\
\text { and horizontal rock crevices } \\
\text { that are typically on east or } \\
\text { southeast aspects, and taller } \\
\text { and larger diameter live trees } \\
\text { and tree snags with loose bark } \\
\text { in mature stands with } \\
\text { southerly aspects and lower } \\
\text { percentages of overstory. } .^{2,4,21,} \\
22,23,30,37,38,39,40,41,44\end{array}$ & $\begin{array}{l}\text { Lactating females moved an average } \\
\text { of } 2,450 \text { meters }+/-845 \text { from roost } \\
\text { to foraging areas and had an average } \\
\text { foraging area size of } 1.56 \text { square km } \\
+/-0.88 \text { SE. Post-lactating females } \\
\text { moved an average of } 210 \text { meters } \\
\text { from roost to foraging areas and had } \\
\text { an average foraging area size of } 5.97 \\
\text { square } k m+/-2.69 \text { SE in northern } \\
\text { California. }{ }^{37} \text { Individuals commuted } 1 \\
\text { to } 4 \text { km between day roosting and } \\
\text { foraging areas, } 0.5 \text { to } 1.5 \text { km } \\
\text { between day roosts and night roosts, } \\
\text { and switched day roosts often, } \\
\text { usually moving }<200 \text { meters } \\
\text { between roosts (range } 25 \text { to } 3,660 \\
\text { meters) in eastern Oregon. }{ }^{38,39} \\
\text { Individuals typically commuted } 1-2 \\
\text { km from day roosts to foraging } \\
\text { areas, but one male often used } \\
\text { different day roosts separated by } 10 \\
\text { km in California. }{ }^{42}\end{array}$ \\
\hline $\begin{array}{l}\text { Townsend's Big-eared Bat } \\
\text { (Corynorhinus townsendii) } \\
\text { High fidelity to maternity and } \\
\text { hibernacula roosts, lower } \\
\text { interseasonal roost site fidelity, } \\
\text { and travel up to } 24 \mathrm{~km} \text { from } \\
\text { hibernacula to summer foraging } \\
\text { areas. }^{73} \text { Forage and commute } \\
\text { adjacent to vegetation. }{ }^{72}\end{array}$ & $\begin{array}{l}\text { Twilight areas of caves, mines, } \\
\text { and unused tunnels in } \\
\text { Montana. }{ }^{1,31,32,75,84} \text { Limestone } \\
\text { or lava tube caves and mines } \\
\text { are known to be used } \\
\text { elsewhere with arousal and } \\
\text { movement within or between } \\
\text { sites, possibly responding to } \\
\text { changing temperature. } 5,73,74,82\end{array}$ & \begin{tabular}{|l|} 
Caves and mines, often in \\
twilight areas in Montana. ${ }^{1,75}$ \\
Reported in caves, mines, \\
buildings, and basal tree \\
hollows elsewhere. ${ }^{2,5,72,73,81,}$ \\
82,83 Females prefer cooler \\
maternity roosts than other \\
vespertilionid bat species. ${ }^{2}$
\end{tabular} & $\begin{array}{l}\text { In Montana, usually in caves } \\
\text { and mines, often in twilight } \\
\text { areas, but more rarely building } \\
\text { attics, root cellars, and } \\
\text { pocket/daylight caves. }{ }^{1,21,31,32,} \\
75 \text { Reported in caves, mines, } \\
\text { buildings and large diameter } \\
\text { basal tree hollows elsewhere. }{ }^{2,} \\
5,72,81,82,83\end{array}$ & $\begin{array}{l}\text { Average one-way travel distances } \\
\text { between day roosts and foraging } \\
\text { areas was } 3.2 \mathrm{~km}+/-0.5 \mathrm{SD} \text { for } \\
\text { males and } 1.3 \mathrm{~km}+/-0.2 \mathrm{SD} \text { for } \\
\text { females in coastal California; } \\
\text { maximum distance traveled from the } \\
\text { day roost was } 10.5 \mathrm{~km} .^{72}\end{array}$ \\
\hline
\end{tabular}




\begin{tabular}{|c|c|c|c|c|}
\hline Species / Comments & Winter Roost & Summer Maternity Roost & Summer Day/Night Roost & Home Range/Foraging Distance \\
\hline $\begin{array}{l}\text { Big Brown Bat } \\
\text { (Eptesicus fuscus) } \\
\text { Males often roost solitarily } \\
\text { during summer. Rarely move } \\
\text { more than } 80 \mathrm{~km} \text { between } \\
\text { summer and winter roosts. }{ }^{2,6} \\
\text { Roost switching is common at } \\
\text { natural roosts, but show high } \\
\text { fidelity to man-made roosts. }{ }^{64,65,} \\
71\end{array}$ & $\begin{array}{l}\text { Caves, mines, and some } \\
\text { evidence for rock crevices } \\
\text { which are probably the most } \\
\text { widespread winter roost in } \\
\text { Montana. }{ }^{1,31,84} \text { Known to use } \\
\text { narrow deep rock crevices or } \\
\text { erosion holes in steep valley } \\
\text { walls on the Canadian prairie } \\
\text { and buildings in Ohio. } 62\end{array}$ & $\begin{array}{l}\text { Buildings, bridges, large } \\
\text { diameter trees snags with } \\
\text { hollows or loose bark in } \\
\text { Montana. }{ }^{1,75} \text { Primarily large } \\
\text { diameter tree snag hollows } \\
\text { and crevices, but also live } \\
\text { aspen hollows, in more } \\
\text { sparsely spaced stands, deep } \\
\text { rock crevices, and older } \\
\text { human structures are known }^{\text {to be used elsewhere. }}{ }^{6,29,59,} \\
64,65,66,67,68,71\end{array}$ & $\begin{array}{l}\text { Rock crevices, buildings, } \\
\text { bridges, and caves in } \\
\text { Montana. }{ }^{1,22,31} \text { Larger } \\
\text { diameter tree snags with } \\
\text { hollows and crevices and } \\
\text { preferential selection for older } \\
\text { more sparsely spaced stands, } \\
\text { older buildings, and rock } \\
\text { crevices with good solar } \\
\text { exposure are known to be } \\
\text { used elsewhere. }{ }^{27,} 29,30,64,65,66, \\
67,68,69,71 \text { Caves and mines } \\
\text { known to be used as night } \\
\text { roosts elsewhere. }{ }^{70,}\end{array}$ & $\begin{array}{l}\text { Average of } 1.5 \mathrm{~km}+/-0.9 \mathrm{SD} \text { (range } \\
0.4 \text { to } 1.8 \mathrm{~km} \text { ) from roosts to } \\
\text { capture locations with average } \\
\text { movement between successive } \\
\text { roosts of } 1.1 \mathrm{~km}+/-0.7 \mathrm{SD} \text { (range } 0.4 \\
\text { to } 2.0 \mathrm{~km} \text { ) in the Black Hills of South } \\
\text { Dakota. }{ }^{29} \text { Average one-way travel } \\
\text { distances between day roosts and } \\
\text { foraging areas of } 1.8 \mathrm{~km}+/-0.1 \mathrm{SE} \text { ) } \\
\text { range }(0.3 \text { to } 4.4 \mathrm{~km} \text { ) in southern } \\
\text { British Columbia. }{ }^{64}\end{array}$ \\
\hline $\begin{array}{l}\text { Spotted Bat } \\
\text { (Euderma maculatum) } \\
\text { High roost site fidelity with } \\
\text { multiple individuals following } \\
\text { the same nightly commuting } \\
\text { routes up side canyons to } \\
\text { foraging areas at speeds of up to } \\
53 \mathrm{~km} / \mathrm{hr}^{8,49} \text { Forage over } \\
\text { clearings and along cliff rims. } \\
50,51\end{array}$ & $\begin{array}{l}\text { Not documented in Montana. } \\
\text { Deep rock cracks and crevices } \\
\text { are commonly used elsewhere } \\
\text { and caves and human } \\
\text { structures are rarely used } \\
\text { elswhere. } 1,2,7,51\end{array}$ & $\begin{array}{l}\text { Not documented in Montana. } \\
\text { Rock cracks and crevices in } \\
\text { upper portions of tall remote } \\
\text { south facing cliffs near } \\
\text { perennial waters are used } \\
\text { elsewhere. }^{1,2,7,8,50}\end{array}$ & $\begin{array}{l}\text { Buildings and other human } \\
\text { structures in Montana. } 1,47 \\
\text { Rock cracks and crevices in } \\
\text { upper portions of tall remote } \\
\text { cliffs near perennial waters, } \\
\text { and, apparently more rarely, } \\
\text { cave entrances and buildings } \\
\text { elsewhere. } 2,7,8,45,46,47,48,49,50 \text {, } \\
51\end{array}$ & $\begin{array}{l}50-60 \mathrm{~km} \text { round trip flight distances } \\
\text { nightly with average home range size } \\
\text { of } 297+/-25 \text { SE (range }=242.5 \text { to } \\
363.8 \text { ) square } \mathrm{km} \text { in northern } \\
\text { Arizona. }{ }^{8} \text { Nightly round trip } \\
\text { commutes of }>77 \mathrm{~km} \text { between day } \\
\text { roosts, foraging areas, and night } \\
\text { roosts that differed in elevation by } \\
\text { ca. } 2,000 \text { meters in northern } \\
\text { Arizona. }{ }^{49} \text { Nightly round trip foraging } \\
\text { flights of } 12 \text { to } 20 \mathrm{~km} \text { in British } \\
\text { Columbia. }{ }^{50}\end{array}$ \\
\hline $\begin{array}{l}\text { Silver-haired Bat } \\
\text { (Lasionycteris noctivagans) }\end{array}$ & $\begin{array}{l}\text { Not documented in Montana. } \\
\text { Known to use loose bark, basal } \\
\text { tree cavities, cavities under } \\
\text { tree roots, and rock crevices } \\
\text { on more southerly aspects and } \\
\text { in older stands of trees, } \\
\text { elsewhere with retreat to } \\
\text { more underground sites at } \\
\text { lower temperatures. }{ }^{93} \text { Use of } \\
\text { mines is also known. }{ }^{94}\end{array}$ & $\begin{array}{l}\text { Large diameter tree snags } \\
\text { with loose bark or cavities in } \\
\text { Montana. } 1,9,26 \text { Hollows and } \\
\text { crevices in live aspen and } \\
\text { large diameter and taller } \\
\text { trees or tree snags in older } \\
\text { lower canopy closure stands } \\
\text { known to be used elsewhere. } \\
9,59,86,90,91,92,95,96\end{array}$ & $\begin{array}{l}\text { Large diameter tree snags with } \\
\text { loose bark or cavities and a } \\
\text { building in Montana. }{ }^{1,26,78} \\
\text { Large diameter trees or tree } \\
\text { snags in older stands with } \\
\text { hollows and crevices are } \\
\text { predominant summer roost } \\
\text { elsewhere, but rock crevices, } \\
\text { buildings, bridges, and other } \\
\text { human structures also used. }{ }^{9} \\
22,86,90,91,96\end{array}$ & $\begin{array}{l}\text { Distance between capture locations } \\
\text { and roost snags ranged from } 0.1 \text { to } \\
3.4 \mathrm{~km} \text { (averages for juvenile males, } \\
\text { juvenile females, adult males, and } \\
\text { adult females were } 1.3,1.5,1.8 \text {, and } \\
0.5 \mathrm{~km} \text {, respectively) in northeastern } \\
\text { Washington. }{ }^{96}\end{array}$ \\
\hline
\end{tabular}




\begin{tabular}{|c|c|c|c|c|}
\hline Species / Comments & Winter Roost & Summer Maternity Roost & Summer Day/Night Roost & Home Range/Foraging Distance \\
\hline $\begin{array}{l}\text { Eastern Red Bat } \\
\text { (Lasiurus borealis) } \\
\text { Species is a solitary rooster at } \\
\text { heights of } 1 \text { to } 6 \text { meters from } \\
\text { the ground, but forage and } \\
\text { migrate in groups. }{ }^{10}\end{array}$ & $\begin{array}{l}\text { Not documented in Montana } \\
\text { and thought to migrate far to } \\
\text { the south where they use tree } \\
\text { roosts on warmer days and } \\
\text { nights and retreat below leaf } \\
\text { litter when temperatures dip } \\
\text { below freezing. }{ }^{10,54}\end{array}$ & \begin{tabular}{|l|} 
Maternity roosts or lactating \\
individuals have not been \\
detected in Montana. \\
Elsewhere, known to roost \\
mostly in dense foliage that \\
provides shade and \\
protection from the wind, but \\
also on trunks, of larger \\
diameter mature deciduous \\
and conifer trees, often in \\
riparian areas. ${ }^{10,52,53,55,56,57}$
\end{tabular} & $\begin{array}{l}\text { Not documented in Montana. } \\
\text { Elsewhere, known to roost } \\
\text { mostly in denser foliage, but } \\
\text { also on trunks, of larger } \\
\text { diameter mature deciduous } \\
\text { and conifer trees, often in } \\
\text { riparian areas. Also more } \\
\text { rarely in shrubs, under leaf } \\
\text { litter, and on human } \\
\text { structures. }^{10,52,53,55,56,57}\end{array}$ & $\begin{array}{l}\text { Maximum distances traveled to } \\
\text { foraging areas averaged } 1.24 \mathrm{~km} \\
\text { (range } 0.19 \text { to } 3.28 \text { ) and foraging } \\
\text { areas averaged } 94.4 \mathrm{Ha}+/-20.2 \mathrm{SE} \\
\text { with no significant differences } \\
\text { between sex and age classes in } \\
\text { Mississippi. }{ }^{52} \text { Maximum distances } \\
\text { traveled from diurnal roosts to } \\
\text { foraging areas ranged from } 1.2 \text { to } 5.5 \\
\text { km for females and } 1.4 \text { to } 7.4 \mathrm{~km} \text { for } \\
\text { males with average foraging area } \\
\text { size of } 334 \mathrm{Ha} \text { in Kentucky }\end{array}$ \\
\hline $\begin{array}{l}\text { Hoary Bat } \\
\text { (Lasiurus cinereus) } \\
\text { Species is a solitary rooster at } \\
\text { heights of } 3 \text { to } 5 \text { meters from } \\
\text { the ground, but forage and } \\
\text { migrate in groups. }{ }^{11}\end{array}$ & $\begin{array}{l}\text { Not documented and thought } \\
\text { to migrate far to the south of } \\
\text { Montana in the winter. }{ }^{11}\end{array}$ & $\begin{array}{l}\text { Only a bridge roost } \\
\text { documented in Montana. }{ }^{1} \\
\text { Known to be a solitary rooster } \\
\text { in deciduous and conifer tree } \\
\text { foliage that offers shelter } \\
\text { from the wind and more } \\
\text { southern exposure to the sun } \\
\text { elsewhere. }{ }^{11,85,86,87,88,89}\end{array}$ & $\begin{array}{l}\text { A bridge and cottonwood } \\
\text { foliage in Montana. }{ }^{1} \text { Known to } \\
\text { roost in deciduous and conifer } \\
\text { tree foliage elsewhere. }{ }^{1,11,85} \\
86,87\end{array}$ & $\begin{array}{l}\text { Females traveled one-way distances } \\
\text { up to } 20 \mathrm{~km} \text { from day roosts while } \\
\text { on first of up to five nightly foraging } \\
\text { bouts in Manitoba Canada. }\end{array}$ \\
\hline $\begin{array}{l}\text { California Myotis } \\
\text { (Myotis californicus) } \\
\text { Roosts alone or in groups. }{ }^{12}\end{array}$ & 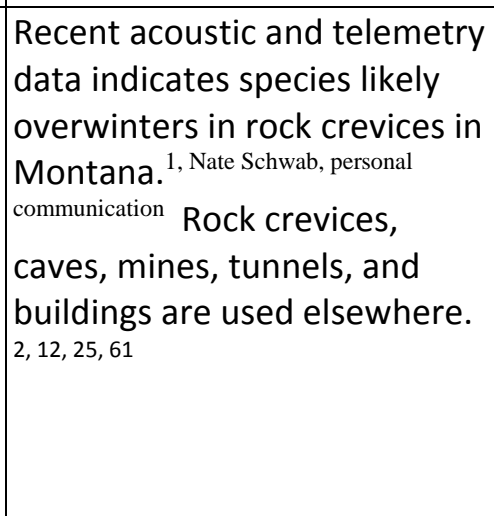 & $\begin{array}{l}\text { Not documented in Montana. } \\
\text { Elsewhere known to roost } \\
\text { under loose bark or in holes } \\
\text { or cracks in more isolated } \\
\text { larger diameter tree snags in } \\
\text { areas with lower canopy } \\
\text { closure. }{ }^{58,59} \text { More rarely, } \\
\text { known to use buildings } \\
\text { elsewhere. }{ }^{60}\end{array}$ & \begin{tabular}{|l|} 
A house and a cellar in \\
Montana. ${ }^{32}$ Elsewhere known \\
to roost under loose bark or in \\
holes or cracks in more \\
isolated larger diameter tree \\
snags in areas with lower \\
canopy closure. ${ }^{58,59}$ Also \\
known to use rock crevices, \\
bridges, buildings, and other \\
human structures elsewhere. \\
$12,21,22,30,60$
\end{tabular} & *No documentation found. \\
\hline \begin{tabular}{|l|} 
Western Small-footed Myotis \\
(Myotis ciliolabrum) \\
Mostly a solitary rooster, but \\
sometimes aggregates in small \\
groups. Fidelity to roost areas is \\
shown, but roost switching \\
within those areas is frequent ${ }^{13,}$ \\
63 Also show a high fidelity to \\
commuting corridors. ${ }^{63}$ \\
\end{tabular} & $\begin{array}{l}\text { Caves and mines documented } \\
\text { in Montana. }{ }^{1,76,84} \text { Known to } \\
\text { use lava tube caves, deep } \\
\text { cracks in ground, deep rock } \\
\text { crevices, tunnels, and drill } \\
\text { holes in rock elsewhere. }{ }^{2,13,77}\end{array}$ & $\begin{array}{l}\text { Rock outcrop crevices with } \\
\text { good solar exposure in } \\
\text { Montana. }{ }^{1} \text { Known to rely } \\
\text { mostly on vertical and } \\
\text { horizontal crevices in cliffs } \\
\text { and rock outcrops, but also } \\
\text { documented using buildings } \\
\text { elsewhere. }{ }^{13,63}\end{array}$ & $\begin{array}{l}\text { Rock outcrop crevices, bridges, } \\
\text { caves, mines, and buildings in } \\
\text { Montana. }{ }^{1,31,32} \text { Known to use } \\
\text { rock outcrops, cracks in } \\
\text { ground, tree hollows, and } \\
\text { trees with loose bark } \\
\text { elsewhere. }{ }^{13,63} \text { No bats were } \\
\text { detected using night roosts in } \\
\text { a north central Oregon study. }{ }^{63} \\
\end{array}$ & $\begin{array}{l}6 \text { to } 24 \mathrm{~km} \text { round trip travel } \\
\text { distances from roosts to foraging } \\
\text { areas in north central Oregon. }{ }^{63}\end{array}$ \\
\hline
\end{tabular}




\begin{tabular}{|c|c|c|c|c|}
\hline Species / Comments & Winter Roost & Summer Maternity Roost & Summer Day/Night Roost & Home Range/Foraging Distance \\
\hline $\begin{array}{l}\text { Long-eared Myotis } \\
\text { (Myotis evotis) } \\
\text { Suspected of only traveling } \\
\text { short distances between } \\
\text { summer and winter roosts. }{ }^{14} \\
\text { Have low fidelity to individual } \\
\text { roosts, but high fidelity to roost } \\
\text { areas. }^{97,98,99}\end{array}$ & $\begin{array}{l}\text { Caves and mines. }{ }^{1,75,84} \text { May } \\
\text { also use deeper rock crevices. } \\
14\end{array}$ & $\begin{array}{l}\text { Caves, cliff and rock outcrop } \\
\text { crevices, and large diameter } \\
\text { trees in Montana. }{ }^{1,26,76} \\
\text { Known to use sheltered } \\
\text { erosion cavities on stream } \\
\text { banks, crevices in basalt, } \\
\text { conifer stumps, conifer snags, } \\
\text { buildings, and mine tunnels } \\
\text { elsewhere. }{ }^{14,97,98,99}\end{array}$ & \begin{tabular}{|l|} 
Large diameter trees, rock \\
outcrops, buildings, and caves \\
in Montana. ${ }^{1,26,31,79}$ Known to \\
use buildings, trees/snags with \\
loose bark, trestle bridges, \\
mines, rock crevices, stream \\
bank cavities, and sink holes \\
elsewhere. ${ }^{14,21,27,97,98,99}$
\end{tabular} & $\begin{array}{l}\text { Traveled an average of } 970 \text { meters } \\
\text { (range } 35-5,154 \text { meters) between } \\
\text { roosts in western Montana. }{ }^{26} \text { Moved } \\
1 \text { to } 812 \text { meters between day roosts } \\
\text { and had roosting home ranges that } \\
\text { ranged from } 0.08 \text { to } 1.93 \text { ha in } \\
\text { Alberta. } .^{97} \text { Traveled } 620 \text { meters from } \\
\text { capture sites to day roosts in } \\
\text { western Oregon } .^{98} \text { Traveled an } \\
\text { average distance between day roosts } \\
\text { of } 148.9 \text { m in northeastern } \\
\text { Washington. } .^{99}\end{array}$ \\
\hline $\begin{array}{l}\text { Little Brown Myotis } \\
\text { (Myotis lucifugus) } \\
\text { Show high fidelity to summer } \\
\text { colonies and hibernacula across } \\
\text { years, but some individuals } \\
\text { relocated between years a } \\
\text { median distance of } 315 \mathrm{~km} \\
\text { between hibernacula (range } 6 \text { to } \\
563 \mathrm{~km} \text { ) and } 431 \mathrm{~km} \text { between } \\
\text { summer roosts (range } 25 \text { to } 464 \\
\mathrm{~km} \text { ). }{ }^{100} \text { Males and } \\
\text { nonreproductive females } \\
\text { occupy cooler roosts than } \\
\text { pregnant or lactating females. }{ }^{15}\end{array}$ & $\begin{array}{l}\text { Caves and mines with high } \\
\text { humidities and temperatures } \\
\text { above freezing in Montana and } \\
\text { elswhere. }{ }^{1,31,36,75,84} \text { May also } \\
\text { use deeper rock crevices. }{ }^{15} \\
\text { Predominantly documented } \\
\text { using caves elsewhere. }{ }^{100}\end{array}$ & \begin{tabular}{|l|} 
Attics and roofs of buildings, \\
bridges, and bat houses in \\
Montana. ${ }^{1}$ Known to use \\
cracks or hollows in larger \\
diameter tree snags in older \\
stands, rock crevices, and \\
buildings elsewhere. $2,15,35,90$, \\
$101,102,103$
\end{tabular} & $\begin{array}{l}\text { Large diameter tree, rock } \\
\text { crevices, buildings, bridges, } \\
\text { caves, and bat houses in } \\
\text { Montana. }{ }^{1,26,31,80} \text { Known to } \\
\text { use cracks or hollows in larger } \\
\text { diameter tree snags in older } \\
\text { stands, wood piles, and rock } \\
\text { crevices elsewhere. }{ }^{15,35,90} \\
\text { Caves and mines known to be } \\
\text { used as night roosts } \\
\text { elsewhere. }\end{array}$ & $\begin{array}{l}\text { Average } 970 \text { meters (range } 35-5,154 \\
\text { meters) between roosts in western } \\
\text { Montana. }{ }^{26} \text { Traveled } 10 \text { to } 647 \mathrm{~km} \\
\text { from hibernacula to summer } \\
\text { colonies in Manitoba and } \\
\text { northwestern Ontario, Canada. }{ }^{100} \\
\text { Female home range averaged } 30.1 \\
\text { ha }+/-15.0 \text { SD during pregnancy and } \\
17.6 \text { ha }+/-9.1 \text { SD during lactation in } \\
\text { Quebec, Canada. } .^{101} \text { Males moved } \\
\text { and average of } 275 \text { m }+/-406 \text { SD } \\
\text { between successive roosts, had } \\
\text { mean minimum roosting areas of } 3.9 \\
\text { ha }+/-7.9 \text { SD, mean minimum } \\
\text { foraging areas of } 52.0 \text { ha }+/-57.4 \text { SD, } \\
\text { mean distance between roosting and } \\
\text { foraging areas of } 254 \text { m }+/-254.2 \text { SD, } \\
\text { and mean distances between } \\
\text { capture sites and first roosts of } 761 \\
m+/-623 \text { SD in New Brunswick. }{ }^{102} \\
\text { Mean home range area was } 143 \text { ha } \\
+/-71.0 \text { SE in New York. } .^{103}\end{array}$ \\
\hline
\end{tabular}




\begin{tabular}{|c|c|c|c|c|}
\hline Species / Comments & Winter Roost & Summer Maternity Roost & Summer Day/Night Roost & Home Range/Foraging Distance \\
\hline $\begin{array}{l}\text { Northern Myotis } \\
\text { ( } M y o t i s ~ s e p t e n t r i o n a l i s) \\
\text { Low roost site fidelity, but often } \\
\text { stay in same general area within } \\
\text { a season. May travel up to } 56 \\
\text { km between summer and winter } \\
\text { roosts. }{ }^{16}\end{array}$ & $\begin{array}{l}\text { Only known from a single } \\
\text { abandoned coal mine in } \\
\text { Montana. }{ }^{1,75} \text { Known from } \\
\text { caves, with a preference to } \\
\text { cluster in deep crevices and } \\
\text { possibly move between caves } \\
\text { within a winter elsewhere. }{ }^{16}\end{array}$ & $\begin{array}{l}\text { Not documented in Montana. } \\
\text { Known to use bark and } \\
\text { hollows of larger diameter } \\
\text { trees, usually in decay, and } \\
\text { building crevices and bat } \\
\text { houses elsewhere. }{ }^{16,29,35,69} \\
102\end{array}$ & $\begin{array}{l}\text { Not documented in Montana. } \\
\text { Known to use bark and } \\
\text { hollows of larger diameter } \\
\text { trees, usually in decay, and } \\
\text { building crevices and bat } \\
\text { houses elsewhere. }{ }^{16,29,35,69} \\
\text { Caves and mines known to be } \\
\text { used as night roosts } \\
\text { elsewhere. }{ }^{70,}\end{array}$ & $\begin{array}{l}\text { Average of } 2.2 \mathrm{~km}+/-1.4 \mathrm{SD} \text { (range } 0.1 \\
\text { to } 5.9 \mathrm{~km} \text { ) from roosts to capture } \\
\text { locations with average movement } \\
\text { between successive roosts of } 0.6 \mathrm{~km}+/ \text { - } \\
0.5 \mathrm{SD}(\text { range } 0.1 \text { to } 1.5 \mathrm{~km} \text { ) in the Black } \\
\text { Hills of South Dakota. } .^{29} \mathrm{Females} / \mathrm{males} \\
\text { moved and average of } 457 / 158 \mathrm{~m}+/- \\
329 / 127 \mathrm{SD} \text { between successive roosts, } \\
\text { had mean minimum roosting areas of } \\
8.6 / 1.4 \text { ha }+/-9.2 / 1.4 \mathrm{SD} \text {, mean } \\
\text { minimum foraging areas of } 46.2 / 13.5 \text { ha } \\
+/-44.4 / 8.3 \mathrm{SD} \text {, mean distance between } \\
\text { roosting and foraging areas of } \\
584.6 / 293.0 \mathrm{~m}+/-405.8 / 282.8 \mathrm{SD} \text {, and } \\
\text { mean distances between capture sites } \\
\text { and first roosts of } 1001 / 402 \mathrm{~m}+/-- \\
693 / 452 \mathrm{SD} \text { in New Brunswick. }\end{array}$ \\
\hline $\begin{array}{l}\text { Fringed Myotis } \\
\text { (Myotis thysanodes) } \\
\text { Very sensitive to roost site } \\
\text { disturbance. }{ }^{17} \text { Maintain at least } \\
\text { some level of group integrity } \\
\text { when switching roosts. }{ }^{29}\end{array}$ & $\begin{array}{l}\text { Not documented in Montana } \\
\text { and presumed to migrate } \\
\text { south of Montana. }{ }^{1}\end{array}$ & $\begin{array}{l}\text { Caves. }{ }^{1} \text { Known to use cracks } \\
\text { and hollows of larger } \\
\text { diameter trees, usually in } \\
\text { decay, rock crevices on south- } \\
\text { facing slopes, and buildings } \\
\text { elsewhere. }{ }^{17,29}\end{array}$ & $\begin{array}{l}\text { Caves in Montana. }{ }^{1,32} \text { Known } \\
\text { to use cracks and hollows of } \\
\text { larger diameter trees, usually } \\
\text { in decay, rock crevices on } \\
\text { south-facing slopes, mines, } \\
\text { buildings, and bridges } \\
\text { elsewhere. }{ }^{17,21,22,29}\end{array}$ & $\begin{array}{l}\text { Average of } 1.0 \mathrm{~km}+/-0.6 \mathrm{SD} \text { (range } \\
0.1 \text { to } 2.0 \mathrm{~km} \text { ) from roosts to } \\
\text { capture locations with average } \\
\text { movement between successive } \\
\text { roosts of } 0.5 \mathrm{~km}+/-0.6 \mathrm{SD} \text { (range } 0.1 \\
\text { to } 2.0 \mathrm{~km} \text { ) in the Black Hills of South } \\
\text { Dakota. }\end{array}$ \\
\hline $\begin{array}{l}\text { Long-legged Myotis } \\
\text { (Myotis volans) }\end{array}$ & $\begin{array}{l}\text { Caves and mines in Montana } \\
\text { and elsewhere. } 1,19,31,36,75,84\end{array}$ & $\begin{array}{l}\text { Large diameter trees in } \\
\text { Montana. }{ }^{1,26} \text { Elsewhere in } \\
\text { taller, but random to normal } \\
\text { diameter tree snags with } \\
\text { loose bark or cracks, } \\
\text { especially in areas with less } \\
\text { habitat fragmentation, } \\
\text { greater snag density but with } \\
\text { greater tree spacing. } 28,33,34, \\
35 \text { Also in rock crevices, cracks } \\
\text { in the ground, and buildings } \\
\text { are known to be used } \\
\text { elsewhere with south-facing } \\
\text { roosts preferred. }{ }^{2,29}\end{array}$ & \begin{tabular}{|l|} 
Buildings, mines, caves and \\
large diameter trees in \\
Montana. $1,26,31,32,78,79$ \\
Elsewhere in taller but random \\
to larger diameter tree snags \\
with loose bark or cracks, \\
especially in areas with less \\
habitat fragmentation, greater \\
snag density but with greater \\
tree spacing, are known to be \\
used elsewhere with south- \\
facing roosts preferred. $27,28,29$, \\
$30,33,34,35$ Also in buildings, \\
cracks in the ground, rock \\
crevices, and caves. ${ }^{19,36}$
\end{tabular} & $\begin{array}{l}\text { Average of } 2.0 \mathrm{~km}+/-0.1 \mathrm{SE} \text { from } \\
\text { roosts to capture locations with } \\
\text { average movement between } \\
\text { successive roosts of } 1.4 \mathrm{~km}+/ \text { - } 0.1 \mathrm{SE} \\
\text { across four study areas in } \\
\text { Washington and Oregon. }{ }^{28} \text { Average } \\
\text { of } 1.9 \mathrm{~km}+/-1.6 \mathrm{SD} \text { (range } 0.4 \text { to } 3.7 \\
\mathrm{~km} \text { ) from roosts to capture locations } \\
\text { with average movement between } \\
\text { successive roosts of } 0.7 \mathrm{~km}+/-0.5 \\
\mathrm{SD} \text { (range } 0.2 \text { to } 1.6 \mathrm{~km} \text { ) in the Black } \\
\text { Hills of South Dakota. }{ }^{29} \text { Average } \\
\text { home range size of } 647 \text { ha }+/-354 \mathrm{SE} \\
\text { (range } 16.5 \text { to } 3,029 \text { ha) for males, } \\
448 \text { ha }+/-78.7 \mathrm{SE} \text { for pregnant } \\
\text { females, and } 304 \text { ha }+/-53.8 \mathrm{SE} \text { for } \\
\text { lactating females in Idaho. }{ }^{33}\end{array}$ \\
\hline
\end{tabular}




\begin{tabular}{|c|c|c|c|c|}
\hline Species / Comments & Winter Roost & Summer Maternity Roost & Summer Day/Night Roost & Home Range/Foraging Distance \\
\hline $\begin{array}{l}\text { Yuma Myotis } \\
\text { (Myotis yumanensis) } \\
\text { Sensitive to roost site } \\
\text { disturbance. }^{2}\end{array}$ & $\begin{array}{l}\text { Not documented in Montana, } \\
\text { but acoustic evidence indicates } \\
\text { overwintering in rock crevices } \\
\text { in cliffs. }{ }^{1}\end{array}$ & $\begin{array}{l}\text { Building, bridges, and bat } \\
\text { houses in Montana. }^{1} \\
\text { Buildings, bridges, caves, } \\
\text { mines, and abandoned cliff } \\
\text { swallow nests are known } \\
\text { elsewhere. }{ }^{2,20,21,22,25}\end{array}$ & $\begin{array}{l}\text { Buildings, bridges, and bat } \\
\text { houses in Montana. }{ }^{1,79} \text { Large } \\
\text { diameter trees, buildings, } \\
\text { rock/cliff crevices and } \\
\text { abandoned cliff swallow nests } \\
\text { elsewhere. }{ }^{2,21,22,23,24,25,30}\end{array}$ & $\begin{array}{l}\text { Average of } 2 \mathrm{~km} \text { (range } 0.59-3.5 \mathrm{~km} \text { ) } \\
\text { from roosts to capture locations in } \\
\text { California. }{ }^{24} 4 \mathrm{~km} \text { from maternity } \\
\text { roost to foraging areas in British } \\
\text { Columbia. }{ }^{25}\end{array}$ \\
\hline
\end{tabular}

${ }^{1}$ supported by observations in Montana's statewide point observation database.

${ }^{2}$ Adams, R.A. 2003. Bats of the Rocky Mountain West: natural history, ecology, and conservation. University Press of Colorado. Boulder, Colorado. 289 p.

${ }^{3}$ Lewis, S,E. 1996. Low roost-site fidelity in pallid bats: associated factors and effect on group stability. Behavioral Ecology and Sociobiology 39:335-344.

${ }^{4}$ Hermanson, J.W. and T.J. O'Shea. 1983. Antrozous pallidus. Mammalian Species Account 213:1-8.

${ }^{5}$ Kunz, T.H. and R.A. Martin. 1982. Plecotus townsendii. Mammalian Species Account 175:1-6.

${ }^{6}$ Kurta, A. and R.H. Baker. 1990. Eptesicus fuscus. Mammalian Species Account 356:1-10.

${ }^{7}$ Watkins, L.C. 1977. Euderma maculatum. Mammalian Species Account 77:1-4.

${ }^{8}$ Chambers, C.L., M.J. Herder, K. Yasuda, D.G. Mikesic, S.M. Dewhurst, W.M. Masters, and D. Vleck. 2011. Roosts and home ranges of spotted bats (Euderma maculatum) in northern Arizona. Canadian Journal of Zoology 89:1256-1267.

${ }^{9}$ Kunz, T.H. 1982. Lasionycteris noctivagans. Mammalian Species Account 172:1-5.

${ }^{10}$ Shump, K.A. Jr. and A.U. Shump. 1982. Lasiurus borealis. Mammalian Species Account 183:1-6.

${ }^{11}$ Shump, K.A. Jr. and A.U. Shump. 1982. Lasiurus cinereus. Mammalian Species Account 185:1-5.

${ }^{12}$ Simpson, M.R. 1993. Myotis californicus. Mammalian Species Account 428:1-4.

${ }^{13}$ Holloway, G.L. and R.M.R. Barclay. 2001. Myotis ciliolabrum. Mammalian Species Account 670:1-5.

${ }^{14}$ Manning, R.W. and J.K. Jones, Jr. 1989. Myotis evotis. Mammalian Species Account 329:1-5.

${ }^{15}$ Fenton, M.B. and R.M.R. Barclay. 1980. Myotis lucifugus. Mammalian Species Account 142:1-8.

${ }^{16}$ Caceres, M.C. and R.M.R. Barclay. 2000. Myotis septentrionalis. Mammalian Species Account 634:1-4.

${ }^{17}$ O'Farrell, M.J. and E.H. Studier. 1980. Myotis thysanodes. Mammalian Species Account 137:1-5.

${ }^{18}$ Keinath, D.A. 2004. Fringed Myotis (Myotis thysanodes): a technical conservation assessment. USDA Forest Service, Rocky Mountain Region. 64 pp. Available at: http://www.fs.fed.us/r2/projects/scp/assessments/fringedmyotis.pdf

${ }^{19}$ Warner, R.M. and N.J. Czaplewski. 1984. Myotis volans. Mammalian Species Account 224:1-4.

${ }^{20}$ Betts, B.J. Microclimate in Hell's Canyon mines used by maternity colonies of Myotis yumanensis. Journal of Mammalogy 78(4):1240-1250.

${ }^{21}$ Dalquest, W.W. 1947. Notes on the natural history of the bat, Myotis yumanensis, in California, with a description of a new race. American Midland Naturalist 38:224-247.

${ }^{22}$ Geluso, K. and J.N. Mink. 2009. Use of bridges by bats (Mammalia: Chiroptera) in the Rio Grande Valley, New Mexico. The Southwestern Naturalist 54(4):421-429.

${ }^{23}$ Licht, P. and P. Leitner. 1967. Behavioral responses to high temperatures in three species of California bats. Journal of Mammalogy 48(1):52-61.

${ }^{24}$ Evelyn, M.J., D.A. Stiles, and R.A. Young. 2004. Conservation of bats in suburban landscapes: roost selection by Myotis yumanensis in a residential area in California. Biological Conservation 115:463-473.

${ }^{25}$ Nagorsen, D.W. and R.M. Brigham. 1993. The bats of British Columbia. University of British Columbia Press, Vancouver.

${ }^{26}$ Schwab, N. 2006. Roost-site selection and potential prey sources after wildland fire for two insectivorous bat species (Myotis evotis and Myotis lucifugus) in midelevation forests of western Montana. Master of Science Thesis. University of Montana. Missoula, MT. $89 \mathrm{pp}$.

${ }^{27}$ Arnett, E.B. and J.P. Hayes. 2009. Use of conifer snags as roosts by female bats in western Oregon. Journal of Wildlife Management 73(2):214-225.

${ }^{28}$ Baker, M.D. and M.J. Lacki. 2006. Day-roosting habitat of female long-legged myotis in ponderosa pine forests. Journal of Wildlife Management 70(1):207-215.

${ }^{29}$ Cryan, P.M., M.A. Bogan, and G.M. Yanega. 2001. Roosting habits of four bat species in the Black Hills of South Dakota. Acta Chiropterologica 3(1):43-52.

${ }^{30}$ Dalquest, W.W. and M.C. Ramage. 1946. Notes on the Long-legged Bat (Myotis volans) at Old Fort Tejon and vicinity, California. Journal of Mammalogy $27(1): 60-63$. 
${ }^{31}$ Hendricks, P., D.L. Genter, and S. Martinez. 2000. Bats of Azure Cave and the Little Rocky Mountains, Montana. The Canadian Field Naturalist 114:89-97.

${ }^{32}$ Hoffman, R.S., D.L. Pattie, and J.F. Bell. 1969. The distribution of some mammals in Montana. II. Bats. Journal of Mammalogy 50(4):737-741.

33 Johnson, J.S., M.J. Lacki, and M.D. Baker. 2007. Foraging ecology of Long-legged Myotis (Myotis volans) in north-central Idaho. Journal of Mammalogy 88(5):12611270.

${ }^{34}$ Lacki, M.J., M.D. Baker, and J.S. Johnson. 2010. Geographic variation in roost-site selection of Long-legged Myotis in the Pacific Northwest. Journal of Wildlife Management 74(6):1218-1228.

${ }^{35}$ Psyllakis, J.M. and R.M. Brigham. 2005. Characteristics of diurnal roosts used by female Myotis bats in sub-boreal forests. Forest Ecology and Management 223:93102.

${ }^{36}$ Schowalter, D.B. 1980. Swarming, reproduction, and early hibernation of Myotis lucifugus and M. volans in Alberta, Canada. Journal of Mammalogy 61(2):350-354.

${ }^{37}$ Baker, M.D., M.J. Lacki, G.A. Falxa, P.L. Droppleman, R.A. Slack, and S.A. Slankard. 2008. Habitat use of Pallid Bats in coniferous forests of northern California. Northwest Science 82(4):269-275.

${ }^{38}$ Lewis, S.E. 1996. Low roost-site fidelity in Pallid Bats: associated factors and effect on group stability. Behavioral Ecology and Sociobiology 39(5):335-344.

39 Lewis, S.E. 1994. Night roosting ecology of Pallid Bats (Antrozous pallidus) in Oregon. American Midland Naturalist 132(2):219-226.

${ }^{40}$ Schorr, R.A. and J.L. Siemers. 2013. Characteristics of roosts of male pallid bats (Antrozouz pallidus) in southeastern Colorado.

${ }^{41}$ Vaughan, T.A. and T.J. O'Shea. 1976. Roosting ecology of the Pallid Bat, Antrozous pallidus. Journal of Mammalogy 57(1):19-42.

42 Brown, P. 1982. Activity patterns and foraging behavior in Antrozous pallidus as determined by radiotelemetry. Bat Research News $23(4): 62$.

${ }^{43}$ Davis, R. 1969. Growth and development of young Pallid Bats, Antrozouz pallidus. Journal of Mammalogy 50(4):729-736.

${ }^{44}$ O'Shea, T.J. 1977. Nocturnal and seasonal activities of the Pallid Bat, Antrozous pallidus. Journal of Mammalogy 58(3):269-284.

${ }^{45}$ Geluso, K. 2000. Distribution of the Spotted Bat (Euderma maculatum) in Nevada, including notes on reproduction. The Southwestern Naturalist 45(3):347-352.

${ }^{46}$ Leonard, M.L. and M.B. Fenton. 1983. Habitat use by Spotted Bats (Euderma maculatum, Chiroptera: Vespertilionidae): roosting and foraging behavior. Canadian Journal of Zoology 61:1487-1491.

${ }^{47}$ Nicholson, A.J. 1950. A record of the Spotted Bat (Euderma maculata) for Montana. Journal of Mammalogy 32(1):197.

${ }^{48}$ Poche, R.M. and G.A. Ruffner. 1975. Roosting behavior of male Euderma maculatum from Utah. Great Basin Naturalist 35(1):121-122.

${ }^{49}$ Rabe, M.J., MS. Siders, C.R. Miller, and T.K. Snow. 1998. Long foraging distance for a Spotted Bat (Euderma maculatum) in northern Arizona. The Southwestern Naturalist 43(2):266-286.

${ }^{50}$ Wai-Ping, V. and M.B. Fenton. 1989. Ecology of Spotted Bat (Euderma maculatum) roosting and foraging behavior. Journal of Mammalogy 70(3):617-622.

${ }^{51}$ Sherwin, R.E. and W.L. Gannon. 2005. Documentation of an urban winter roost of the Spotted Bat (Euderma maculatum). The Southwestern Naturalist 50(3):402407.

${ }^{52}$ Elmore, L., D.A. Miller, and F.J. Vileella. 2005. Foraging area size and habitat use by red bats (Lasiurus borealis) in an intensively managed pine landscape in Mississippi. American Midland Naturalist 153:405-417.

${ }^{53}$ Hutchinson, J.T. and M.J. Lacki. 1991. Foraging behavior and habitat use of red bats in mixed mesophytic forests of the Cumberland Plateau, Kentucky. P. 171-177 in J.W. Stringer and D.L. Loftis (eds.). 12 ${ }^{\text {th }}$ Central Hardwood Forest Conference, U.S. Forest Service Southeast Experiment Station, Asheville, North Carolina.

${ }^{54}$ Mormann, B.M., M. Milam, and L. Robbins. 2004. Red bats do it in the dirt. Bats 22(2):6-9.

${ }^{55}$ Perry, R.W., R.E. Thill, and S.A. Carter. 2007. Sex-specific roost selection by adult red bats in a diverse forested landscape. Forest Ecology and Management 253:4855.

${ }^{56}$ Mager, K.J. and T.A. Nelson. 2001. Roost-site selection by Eastern Red Bats (Lasiurus borealis). American Midland Naturalist 145:120-126.

${ }^{57}$ Limpert, D.L., D.L. Birch, M.S. Scott, M. Andre, and E. Gillam. 2007. Tree selection and landscape analysis of Eastern Red Bat day roosts. Journal of Wildlife Management 71(2):478-486.

${ }^{58}$ Brigham, R.M., M.J. Vonhof, R.M.R. Barclay, and J.C. Gwilliam. 1997. Roosting behavior and roost-site preferences of forest-dwelling California bats (Myotis californicus). Journal of Mammalogy 78(4):1231-1239.

${ }^{59}$ Vonhof, M.J. and J.C. Gwilliam. 2007. Intra- and interspecific patterns of day roost selection by three species of forest-dwelling bats in southern British Columbia. Forest Ecology and Management 252:165-175. 
${ }^{60}$ Krutzsch, P.H. Notes on the habits of the bat, Myotis californicus. Journal of Mammalogy 35(4):539-545.

${ }^{61}$ Young, D.B. and J.F. Scudday. 1975. An incidence of winter activity in Myotis californicus. The Southwestern Naturalist $19(4): 452$.

${ }^{62}$ Lausen, C.L. and R.M.R. Barclay. 2006. Winter bat activity in the Canadian prairies. Canadian Journal of Zoology 84:1079-1086.

${ }^{63}$ Rodhouse, T. and K.J. Hyde. 2014. Roost and forage site fidelity of Western Small-footed Myotis (Myotis ciliolabrum) in an Oregon desert canyon. Western North American Naturalist 74(2):241-248.

${ }^{64}$ Brigham, R.M. 1991. Flexibility in foraging and roosting behavior by the Big Brown Bat (Eptesicus fuscus). Canadian Journal of Zoology 69:117-121.

${ }^{65}$ Lausen, C.L. and R.M.R. Barclay. 2002. Roosting behavior and roost selection of female Big Brown Bats (Eptesicus fuscus) roosting in rock crevices in southeastern Alberta. Canadian Journal of Zoology 80: 1069-1076.

${ }^{66}$ Lausen, C.L. and R.M.R. Barclay. 2003. Thermoregulation and roost selection by reproductive female Big Brown Bats (Eptesicus fuscus) roosting in rock crevices. Journal of Zoology 260:235-244.

${ }^{67}$ Willis, C.K.R., C.M. Voss, and R.M. Brigham. 2006. Roost selection by forest-living female Big Brown Bats (Eptesicus fuscus). Journal of Mammalogy 87(2):345-350.

${ }^{68}$ Neubaum, D.J., K.R. Wilson, and T.J. O'Shea. 2007. Urban maternity-roost selection by Big Brown Bats in Colorado. Journal of Wildlife Management 71(3):728-736.

${ }^{69}$ Whitaker, J.O. Jr., D.W. Sparks, and V. Brack Jr. 2006. Use of artificial roost structures by bats at the Indianapolis International Airport. Environmental Management 38(1):28-36.

${ }^{70}$ Agosta, S.J., D. Morton, B.D. Marsh, and K.M. Kuhn. 2005. Nightly, seasonal, and yearly patterns of bat activity at night roosts in the central Appalachians. Journal of Mammalogy 86(6):1210-1219.

${ }^{71}$ Rancourt, S.J., M.I. Rule, and M.A. O'Connell. 2007. Maternity roost site selection of Big Brown Bats in ponderosa pine forests of the channeled scablands of northeastern Washington State, USA. Forest Ecology and Management 248:183-192.

${ }^{72}$ Fellers, G.M. and E.D. Pierson. 2002. Habitat use and foraging behavior of Townsend's Big-eared Bat (Corynorhinus townsendii) in coastal California. Journal of Mammalogy 83(1):167-177.

${ }^{73}$ Dobkin, D.S., R.D. Gettinger, and M.G. Gerdes. 1995. Springtime movements, roost use, and foraging activity of Townsend's Big-eared Bat (Plecotus townsendii) in central Oregon. Great Basin Naturalist 55(4):315-321.

${ }^{74}$ Genter, D.L. 1986. Wintering bats of the upper Snake River plain: occurrence in lava tube caves. Great Basin Naturalist 46(2):241-244.

${ }^{75}$ Swenson, J.E. and G.F. Shanks Jr. 1979. Noteworthy records of bats from northeastern Montana. Journal of Mammalogy 60(3):650-652.

${ }^{76}$ Jones, J.K. Jr., R.P. Lampe, C.A. Spenrath, and T.H. Kunz. 1973. Notes on the distribution and natural history of bats in southeastern Montana. Occasional papers of the Museum of Texas Tech University 15:1-11.

${ }^{77}$ Swenson, J.E. 1970. Notes on distribution of Myotis leibii in eastern Montana. Blue Jay 28:173-174.

${ }^{78}$ Swenson, J.E. and J.C. Bent. 1977. The bats of Yellowstone County, southcentral Montana. Proceedings of the Montana Academy of Sciences 37:82-84.

${ }^{79}$ Bell, J.F., G.J. Moore, G.H. Raymond, and C.E. Tibbs. 1962. Characteristics of rabies in bats in Montana. American Journal of Public Health 52(8):1293-1301.

${ }^{80}$ Bell, J.F. and L.A. Thomas. 1964. A new virus, "MML," enzootic in bats (Myotis lucifugus) of Montana. American Journal of Tropical Medicine and Hygiene 13(4): 607612.

${ }^{81}$ Sherwin, R.E., W.L. Gannon, and J.S. Altenbach. 2003. Managing complex systems simply: understanding inherent variation in the use of roosts by Townsend's Bigeared Bat. Wildlife Society Bulletin 31(1):62-72.

82 Sherwin, R.E., D. Stricklan, and D.S. Rogers. 2000. Roosting affinities of Townsend's Big-eared Bat (Corynorhinus townsendii) in northern Utah. Journal of Mammalogy 81(4):939-947.

${ }^{83}$ Mazurek, M.J. 2004. A maternity roost of Townsend's Big-eared Bats (Corynorhinus towsendii) in coast redwood basal hollows in northwestern California. Northwestern Naturalist 85(2):60-62.

${ }^{84}$ Hendricks, P. 2012. Winter records of bats in Montana. Northwestern Naturalist 93(2):154-162.

${ }^{85}$ Barclay, R.M.R. 1989. The effect of reproductive condition on the foraging behavior of female Hoary Bats, Lasiurus cinereus. Behavioral Ecology and Sociobiology 24(1):31-37.

${ }^{86}$ Barclay, R.M.R. 1985. Long- versus short-range foraging strategies of Hoary (Lasiurus cinereus) and Silver-haired (Lasionycteris noctivagans) bats and the consequences for prey selection. Canadian Journal of Zoology 63:2507-2515. 
${ }^{87}$ Veilleux, J.P., P.R. Moosman, Jr., D.S. Reynolds, K.E. LaGory, and L.J. Walston, Jr. 2009. Observations of summer roosting and foraging behavior of a Hoary Bat (Lasiurus cinereus) in Southern New Hampshire. Northeastern Naturalist 16(1):148-152

${ }^{88}$ Klug, B.J., D.A. Goldsmith, and R.M.R. Barclay. 2012. Roost selection by the solitary, foliage-roosting Hoary Bat (Lasiurus cinereus) during lactation. Canadian Journal of Zoology 90:329-336.

${ }^{89}$ Willis, C.K.R. and R.M. Brigham. 2005. Physiological and ecological aspects of roost selection by reproductive female Hoary Bats (Lasiurus cinereus). Journal of Mammalogy 86(1):85-94.

${ }^{90}$ Crampton, L.H. and R.M.R. Barclay. 1998. Selection of roosting and foraging habitat by bats in different-aged aspen mixedwood stands. Conservation Biology 12(6):1347-1358.

${ }^{91}$ Mattson, T.A., S.W. Buskirk, and N.L. Stanton. 1996. Roost sites of the Silver-haired Bat (Lasionycteris noctivagans) in the Black Hills, South Dakota. Great Basin Naturalist 56(3):247-253.

92 Betts, B.J. 1998. Roosts used by maternity colonies of Silver-haired Bats in northeastern Oregon. Journal of Mammalogy 79(2):643-650.

${ }^{93}$ Perry, R.W., D.A. Saugey, and B.G. Crump. 2010. Winter roosting ecology of Silver-haired Bats in an Arkansas Forest. Southeastern Naturalist 9(3):563-572.

${ }_{94}$ Pearson, E.W. 1962. Bats hibernating in silica mines in southern Illinois. Journal of Mammalogy 43(1):27-33.

${ }^{95}$ Parson, H.J., D.A. Smith, and R.F. Whittam. 1986. Maternity colonies of Silver-haired Bats, Lasionycteris noctivagans, in Ontario and Saskatchewan. Journal of Mammalogy 67(3):598-600.

${ }^{96}$ Campbell, L.A., J.G. Hallet, and M.A. O'Connell. 1996. Conservation of bats in managed forests: use of roosts by Lasionycteris noctivagans. Journal of Mammalogy 77(4):976-984.

${ }^{97}$ Nixon, A.E., J.C. Gruver, and R.M.R. Barclay. 2009. Spatial and temporal patterns of roost use by western long-eared bats (Myotis evotis). American Midland Naturalist 162:139-147.

${ }^{98}$ Waldien, D.L., J.P. Hayes, and E.B. Arnett. 2000. Day-roosts of female Long-eared Myotis in western Oregon. The Journal of Wildlife Management 64(3):785-796.

${ }^{99}$ Rancourt, S.J., M.I. Rule, and M.A. O'Connell. 2005. Maternity roost site selection of Long-eared Myotis, Myotis evotis. Journal of Mammalogy 86(1):77-84.

${ }^{100}$ Norquay, K.J.O., F. Martinez-Nunez, J.E. DuBois, K.M. Monson, and C.K.R. Wills. 2013. Long-distance movements of Little Brown Myotis (Myotis lucifugus). Journal of Mammalogy 94(2):506-515.

${ }^{101}$ Henry, M., D.W. Thomas, R. Vaudry, and M. Carrier. 2002. Foraging distances and home range of pregnant and lactating Little Brown Bats (Myotis lucifugus). Journal of Mammalogy 83(3):767-774.

${ }^{102}$ Broders, H.G., G.J.Forbes, S. Woodley, and I.D. Thompson. 2006. Range extent and stand selection for roosting and foraging in forest-dwelling Northern Long-eared Bats and Little Brown Bats in the Greater Fundy Ecosystem, New Brunswick. Journal of Wildlife Management 70(5):1174-1184.

${ }^{103}$ Coleman, L.S., W.M. Ford, C.A. Dobony, and E.R. Britzke. 2014. Comparison of radio-telemetric home-range analysis and acoustic detection for Little Brown Bat habitat evaluation. Northeastern Naturalist 21(3):431-445. 
Overview of Known Bat Roosts in Montana
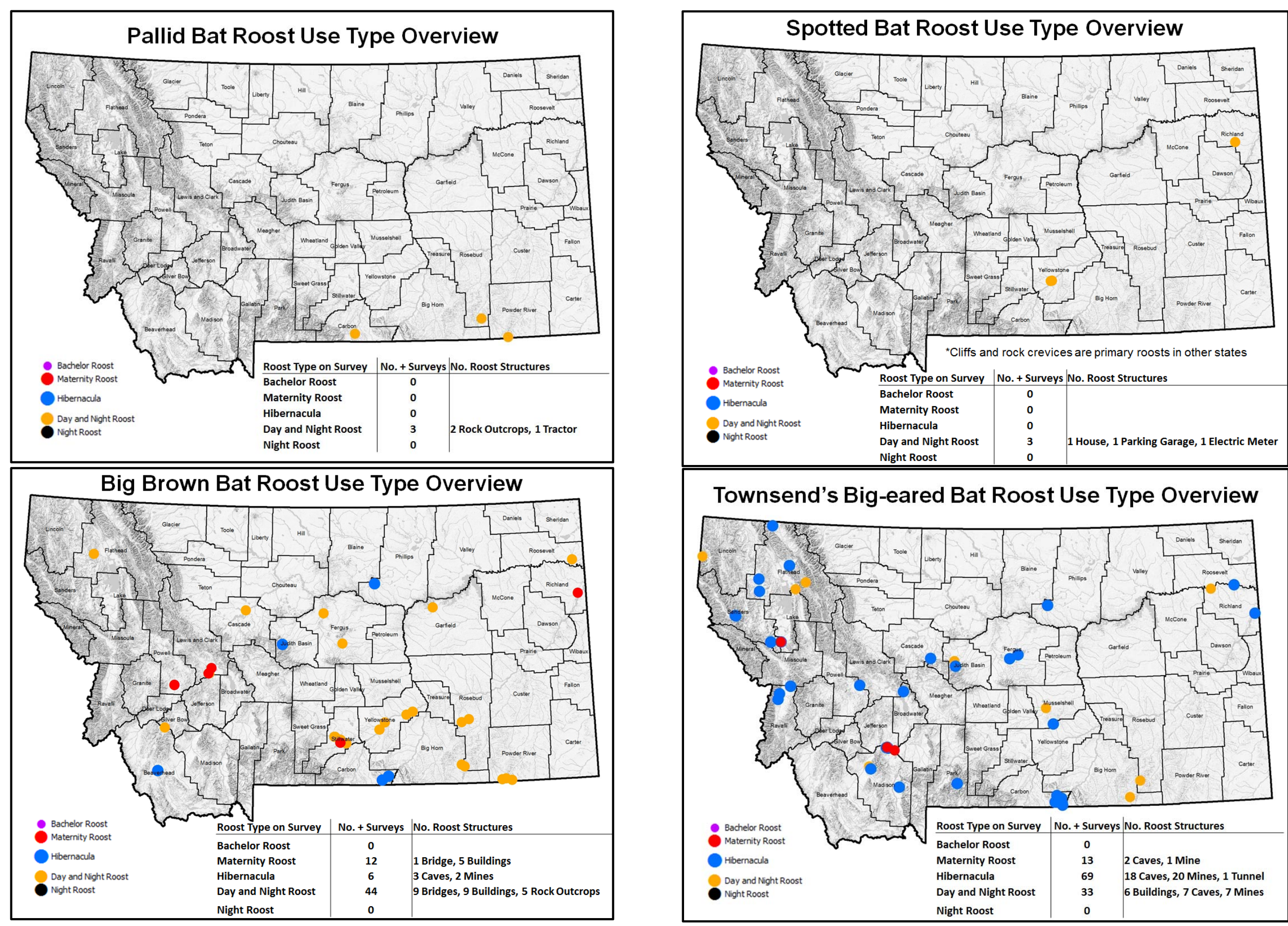

Townsend's Big-eared Bat Roost Use Type Overview

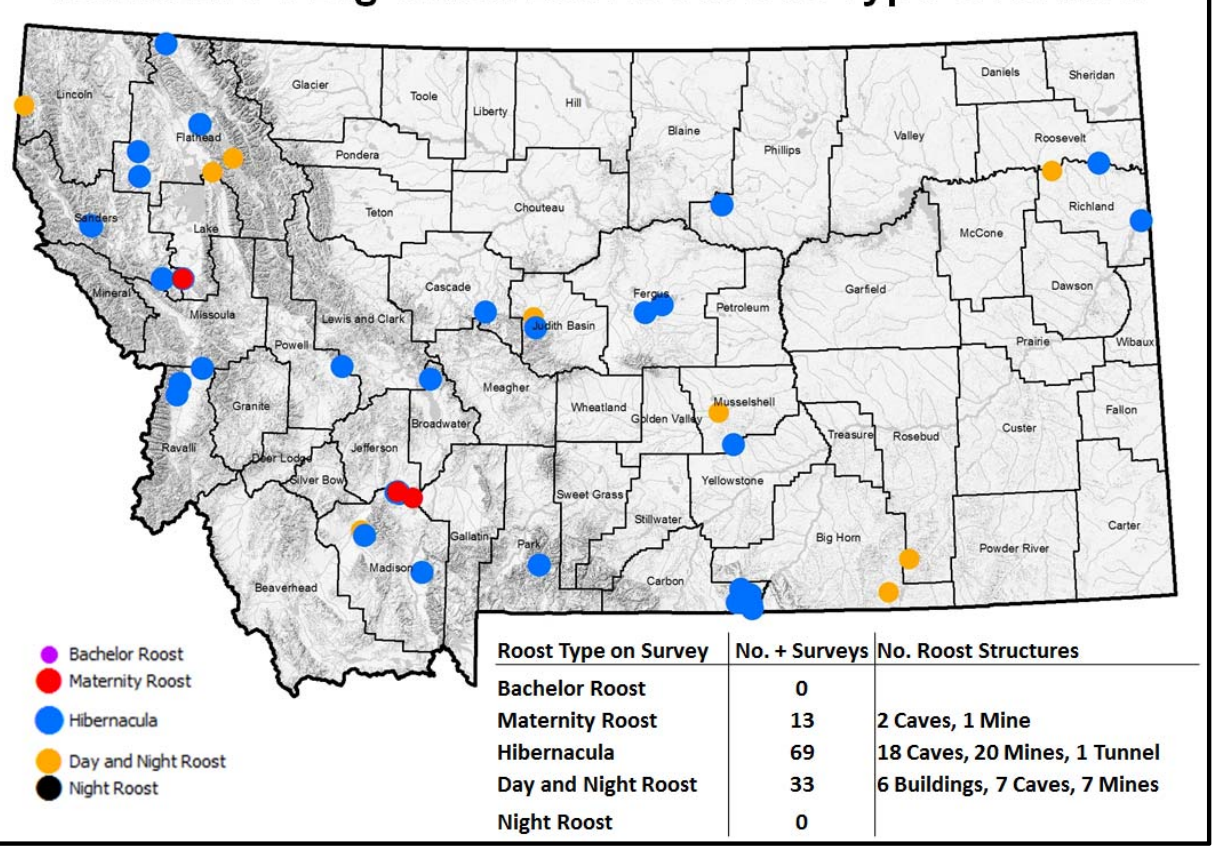



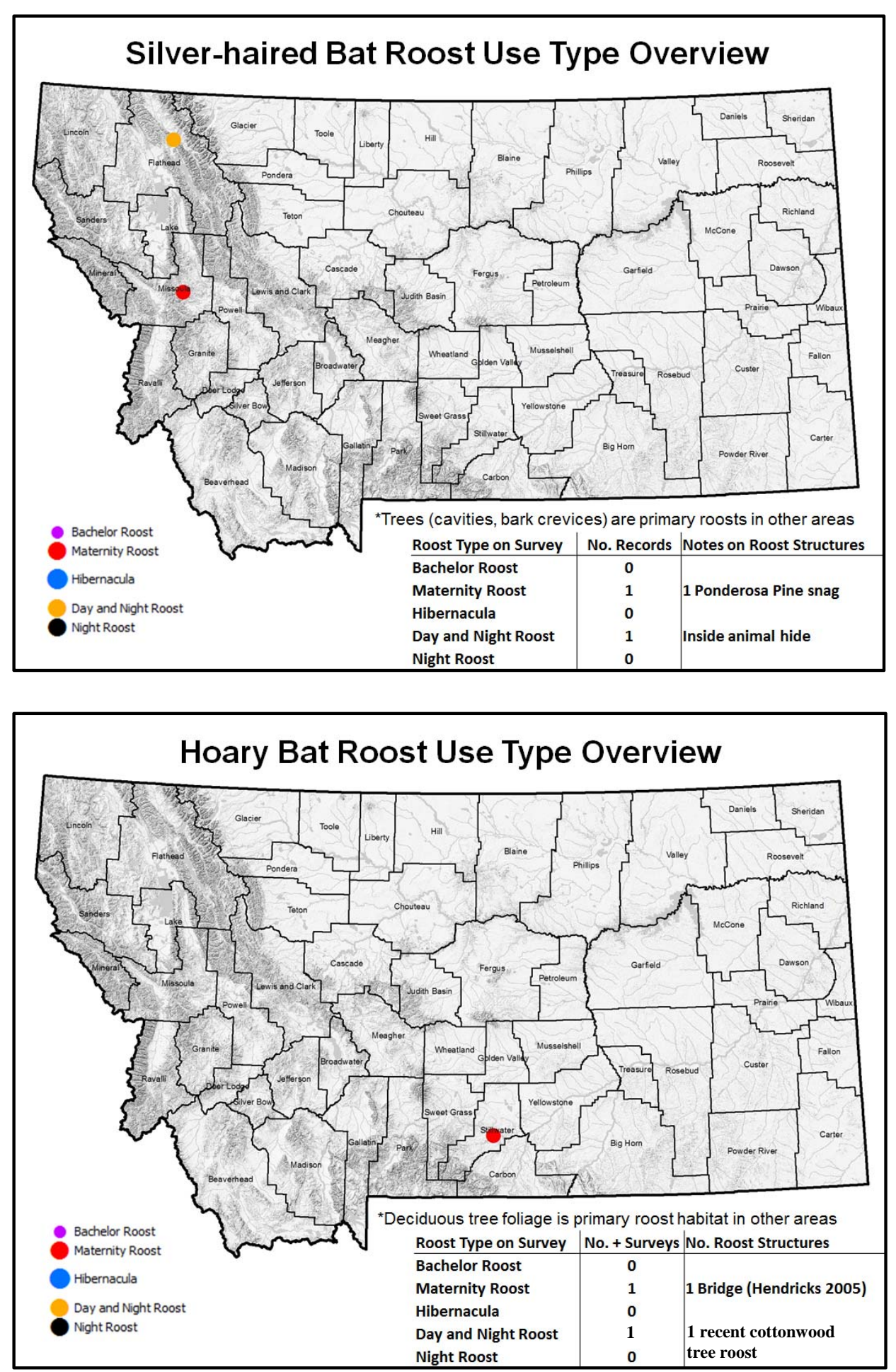

*No roost information is available for Eastern Red Bat in Montana, but the species is known to roost in deciduous tree foliage in other states and most acoustic or mist netting records in Montana are from areas adjacent to floodplains with cottonwood gallery forests.
${ }^{*}$ Recent radio telemetry data indicates California Myotis likely use tree and rock crevice roosts in the summer and rock crevice roosts in the winter in Montana (Nate Schwab, personal communication). The species is known to roost in rock crevices, trees, caves, and mines in other states. 

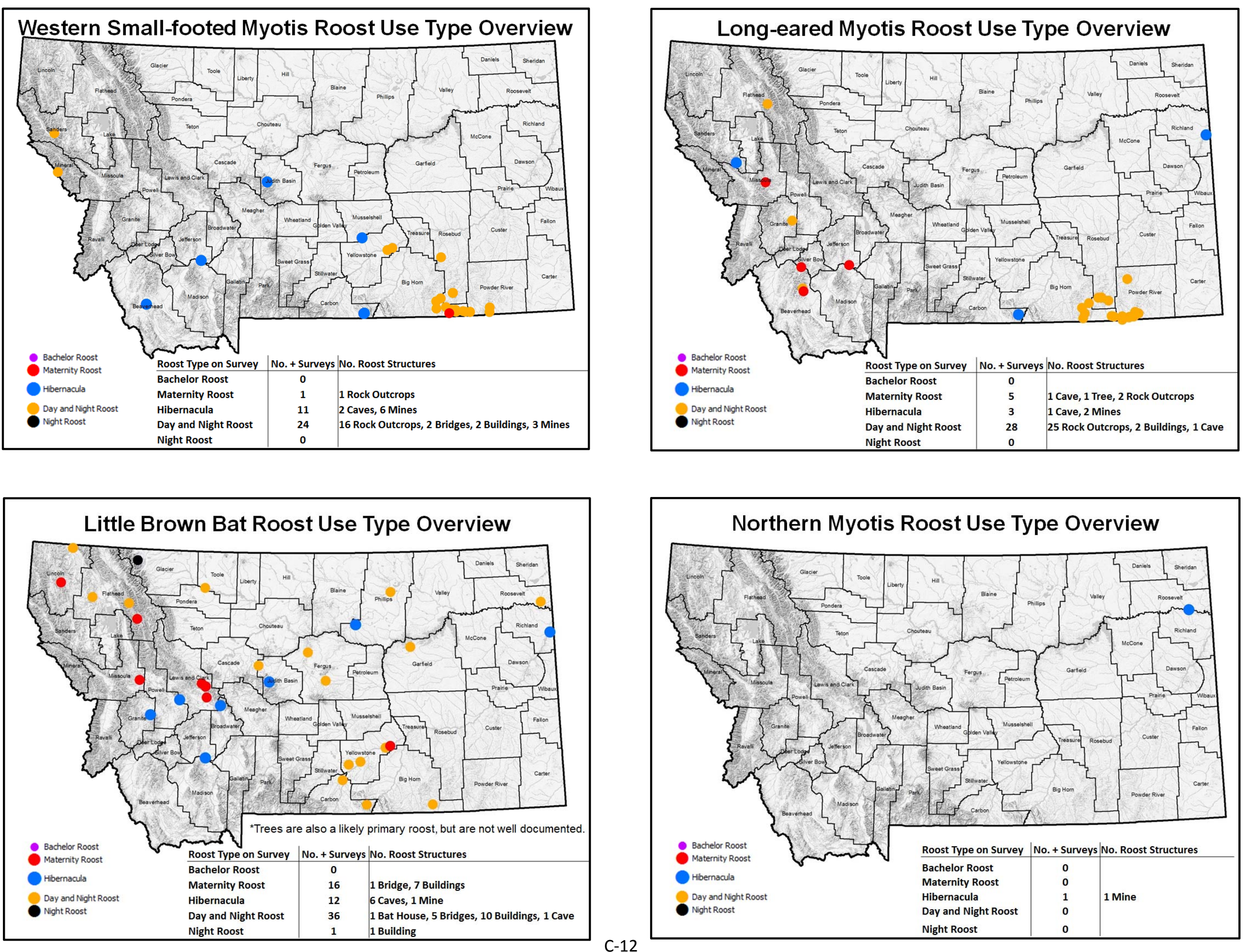

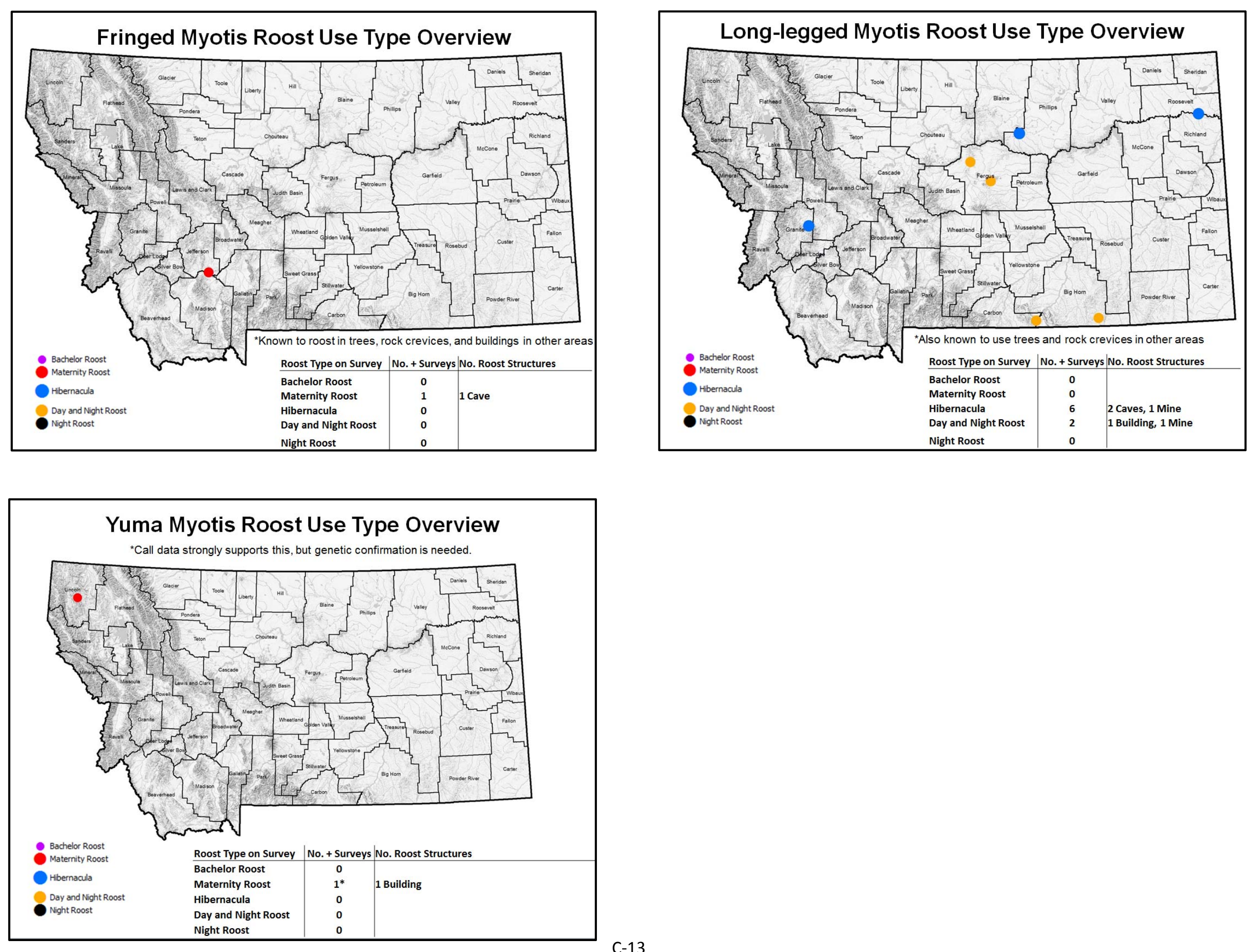


\section{Examples of Winter Roosts for Montana Bats}
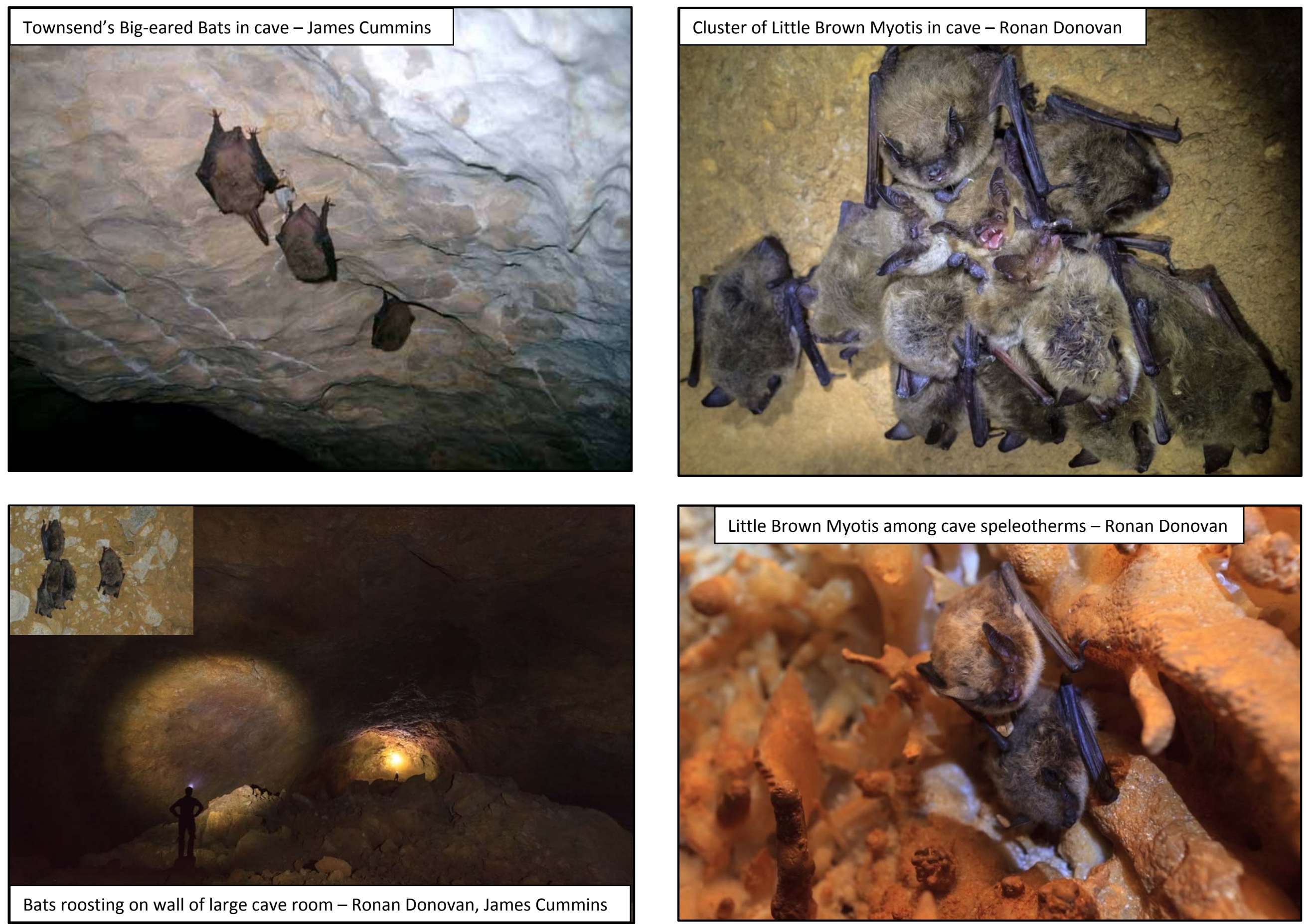

Bats roosting on wall of large cave room - Ronan Donovan, James Cummins 

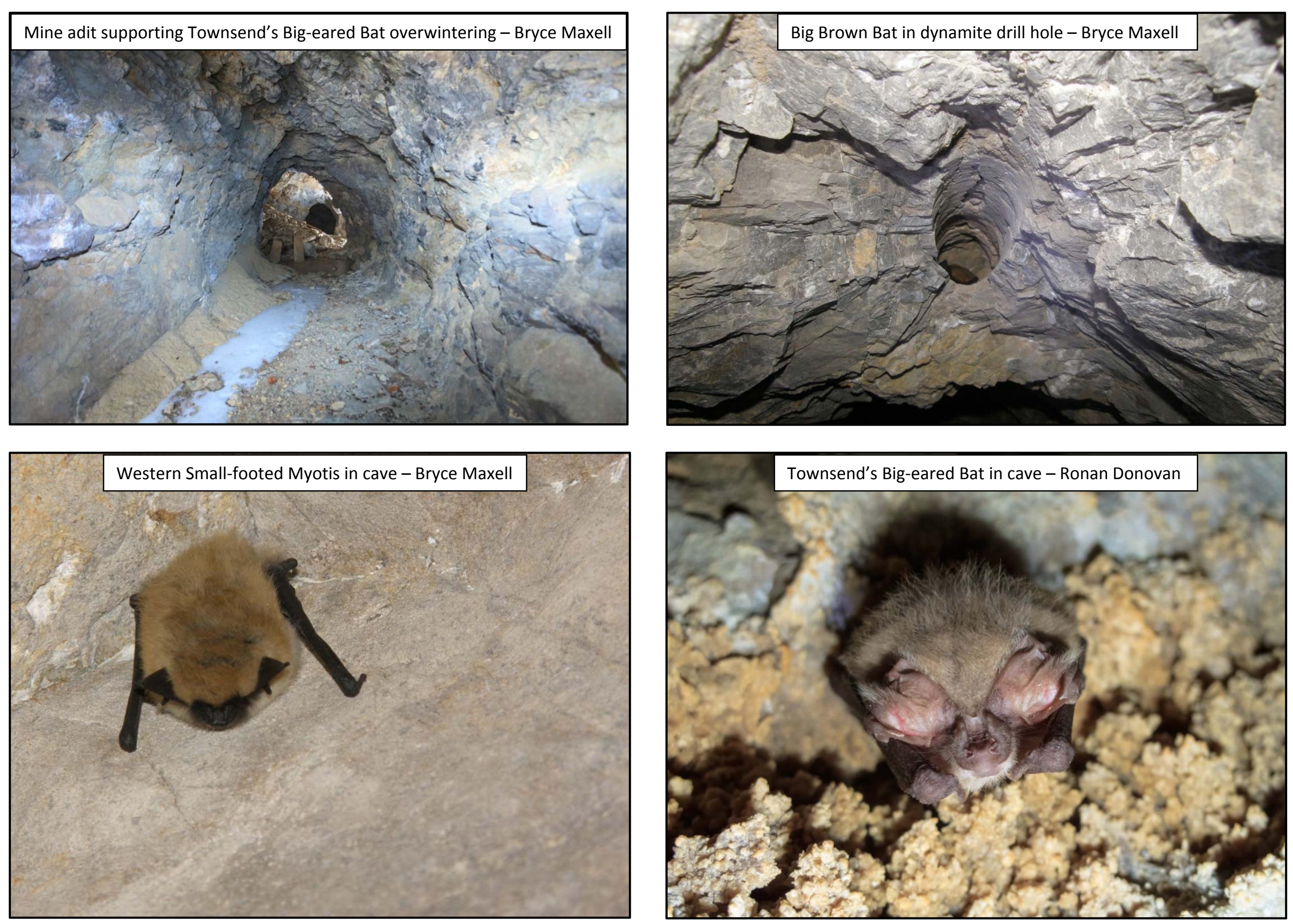

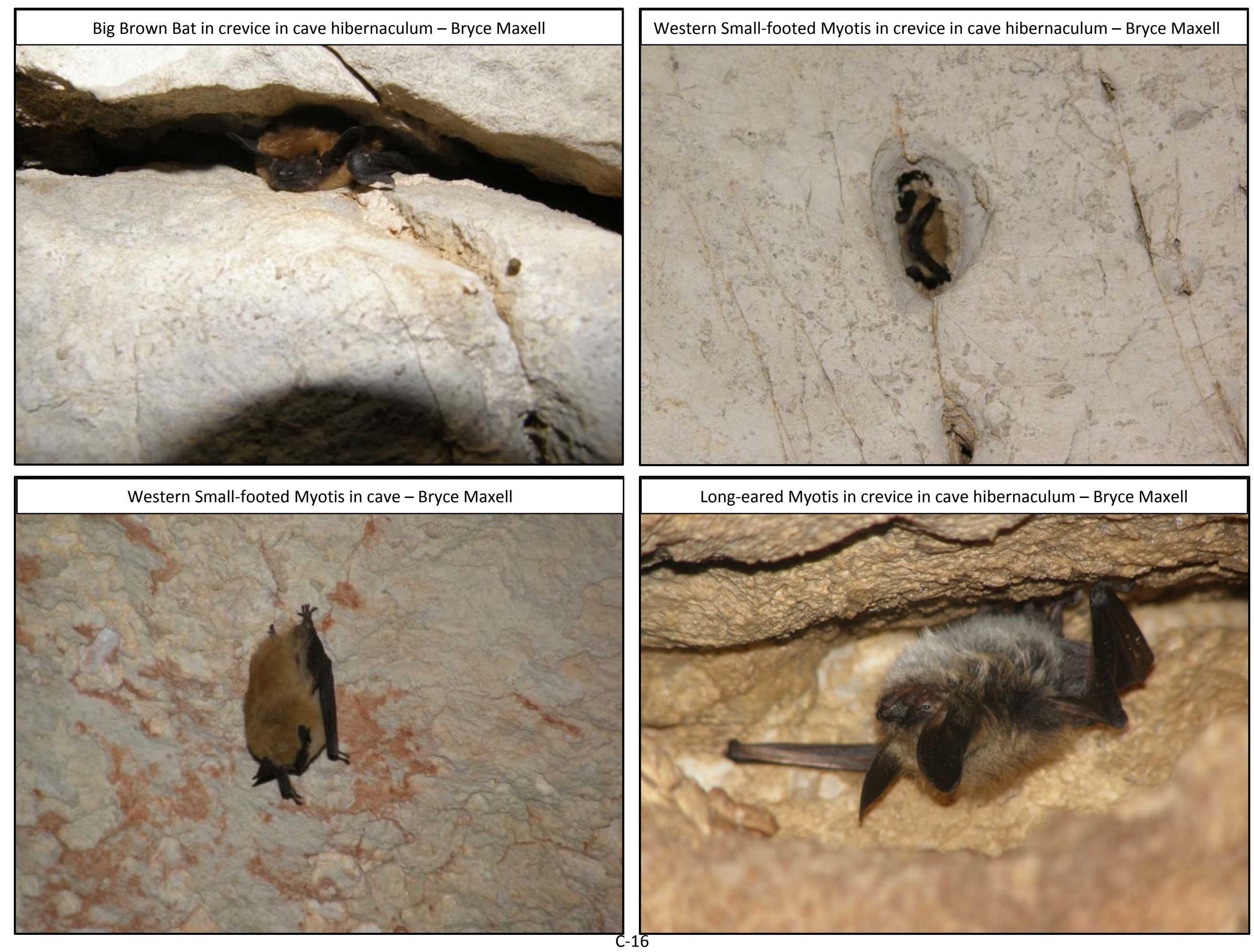

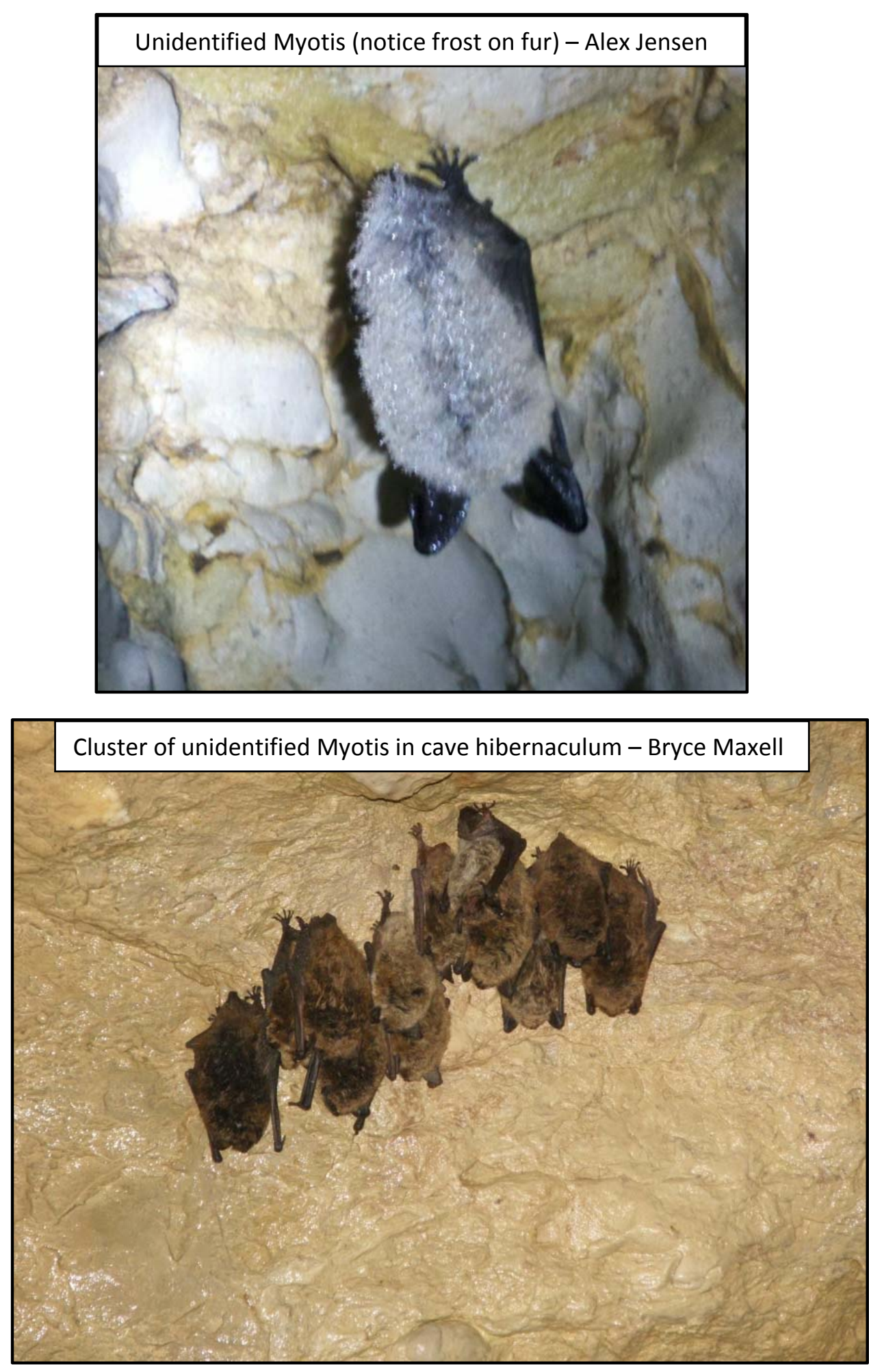
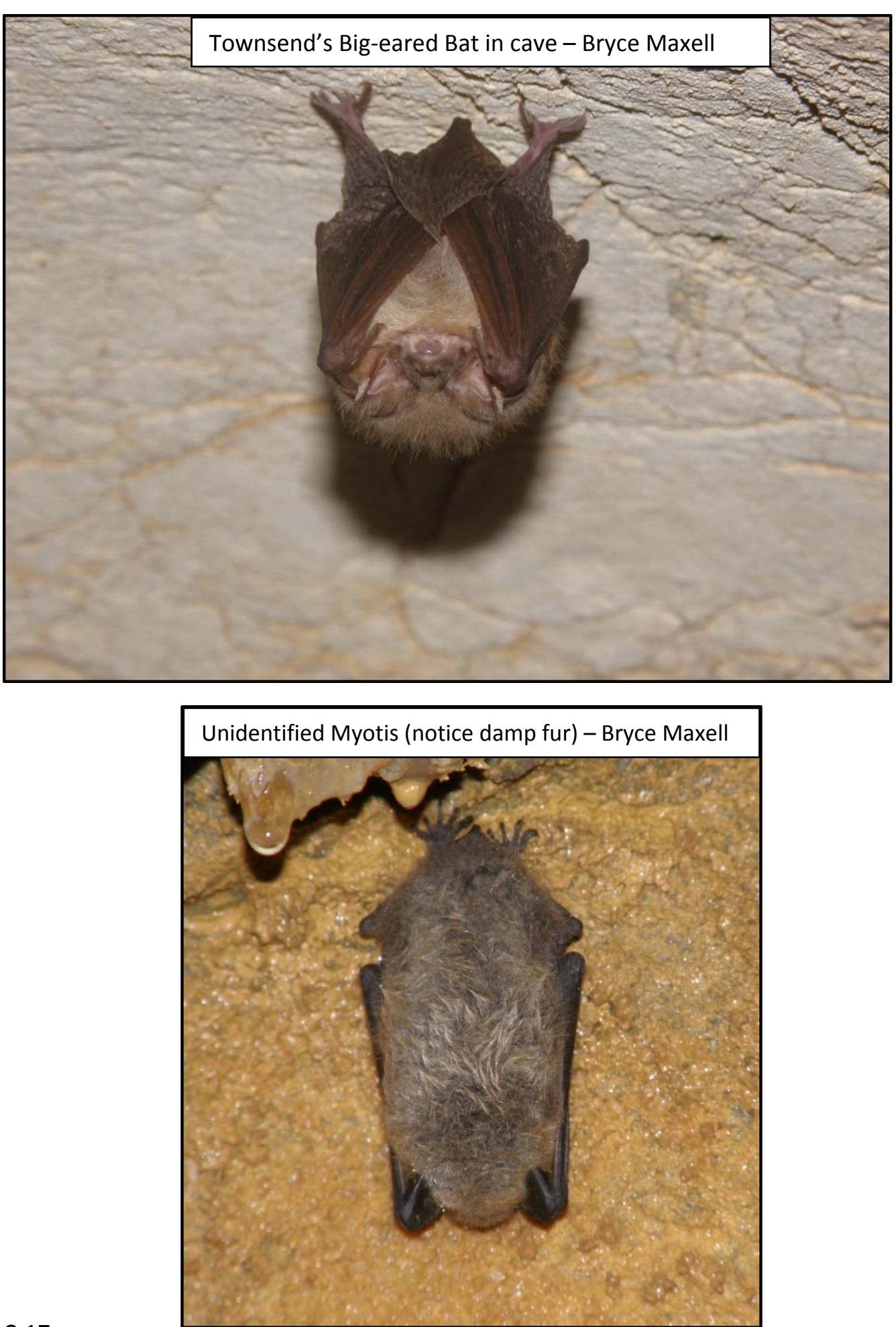


\section{Examples of Summer Maternity Roosts for Montana Bats}

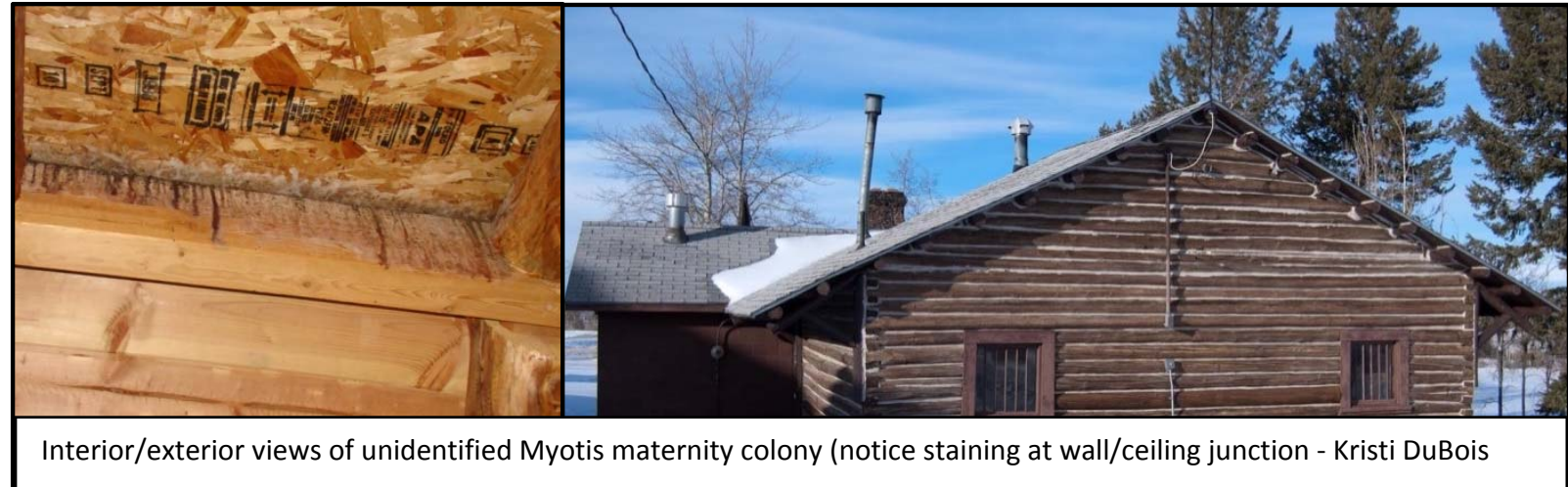

\begin{tabular}{l} 
Unidentified Myotis maternity roost behind south facing sign on \\
brick wall - Bryce Maxell \\
\hline STATE OF MONTANA
\end{tabular}
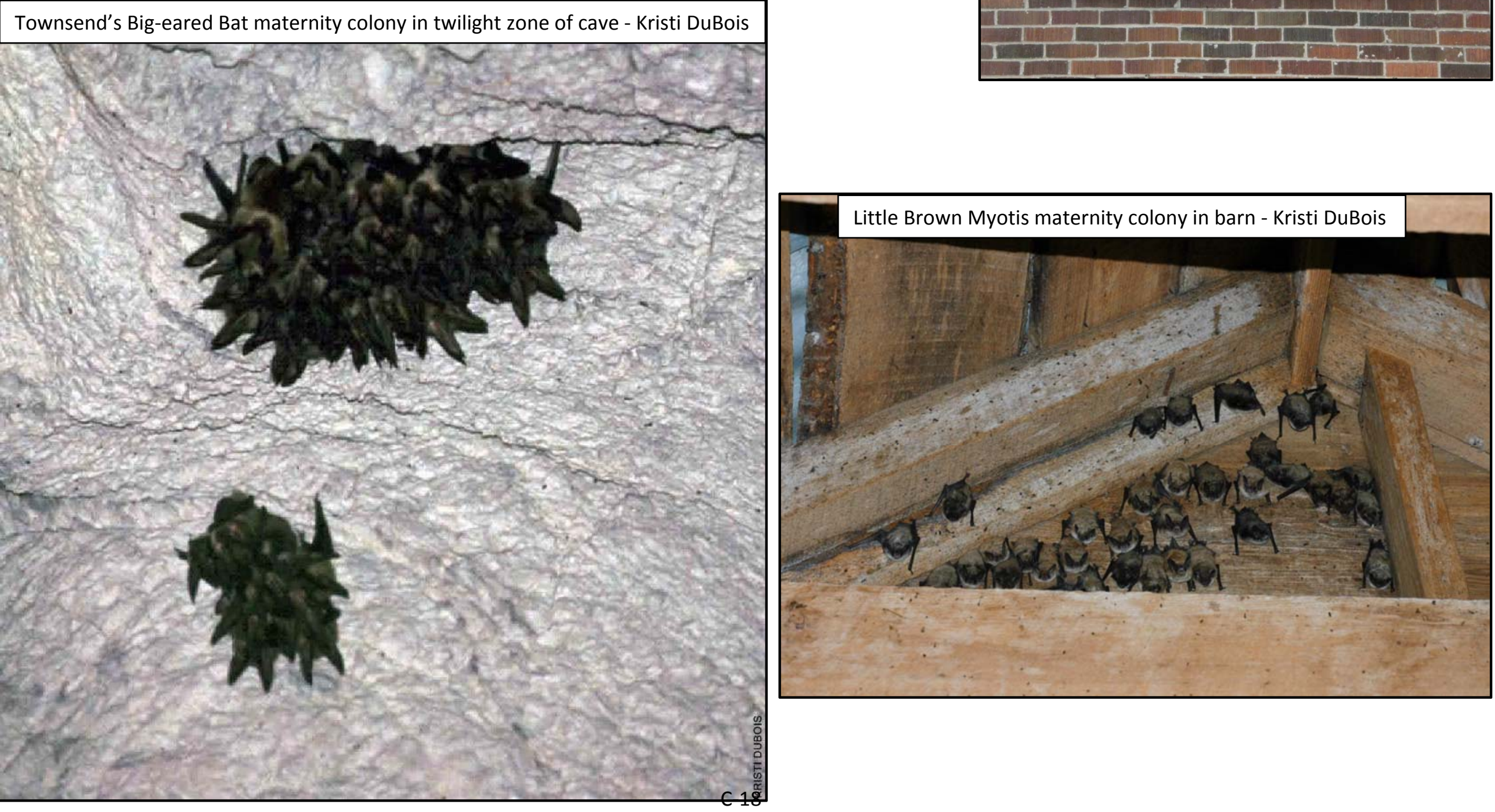


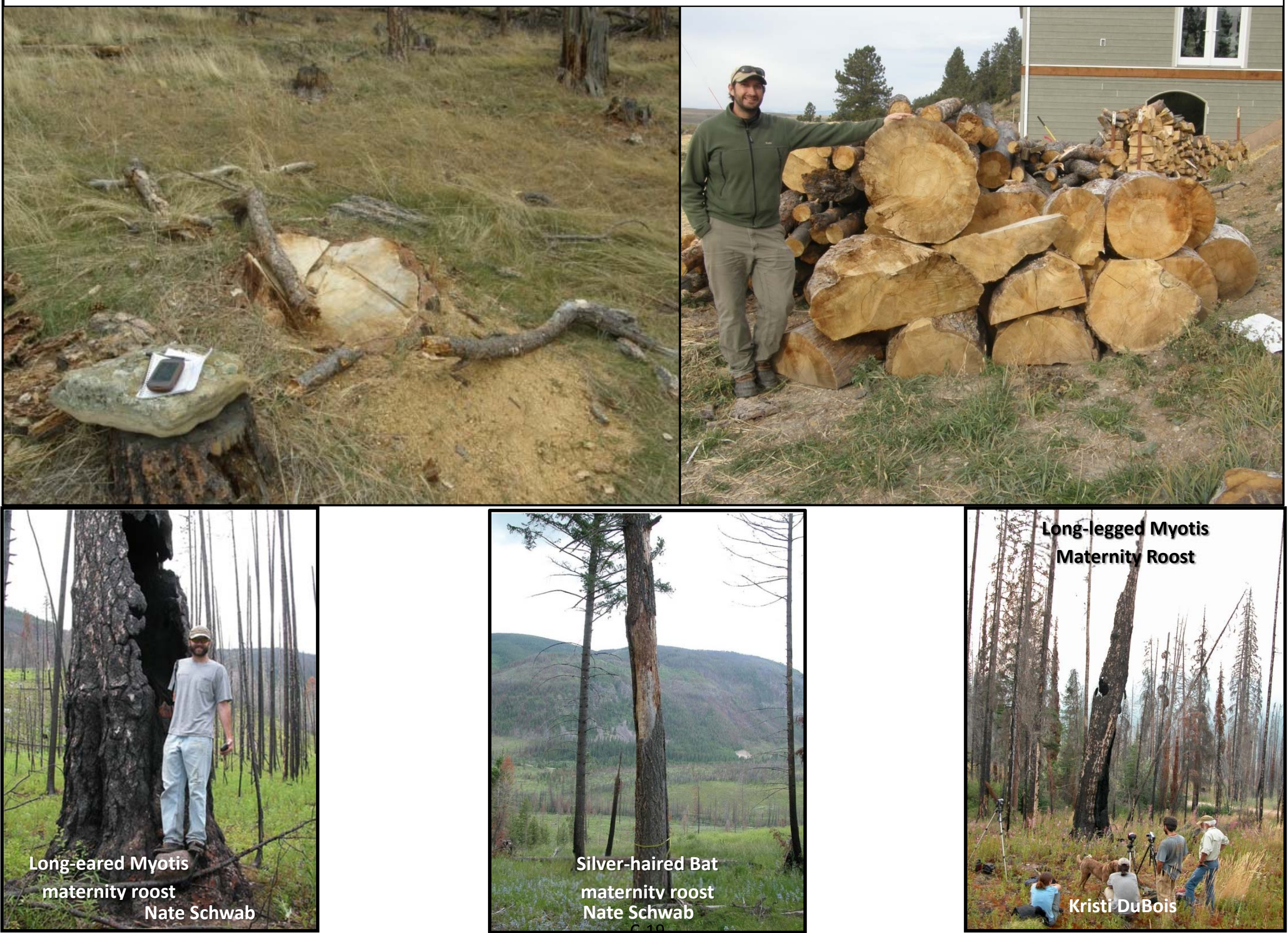



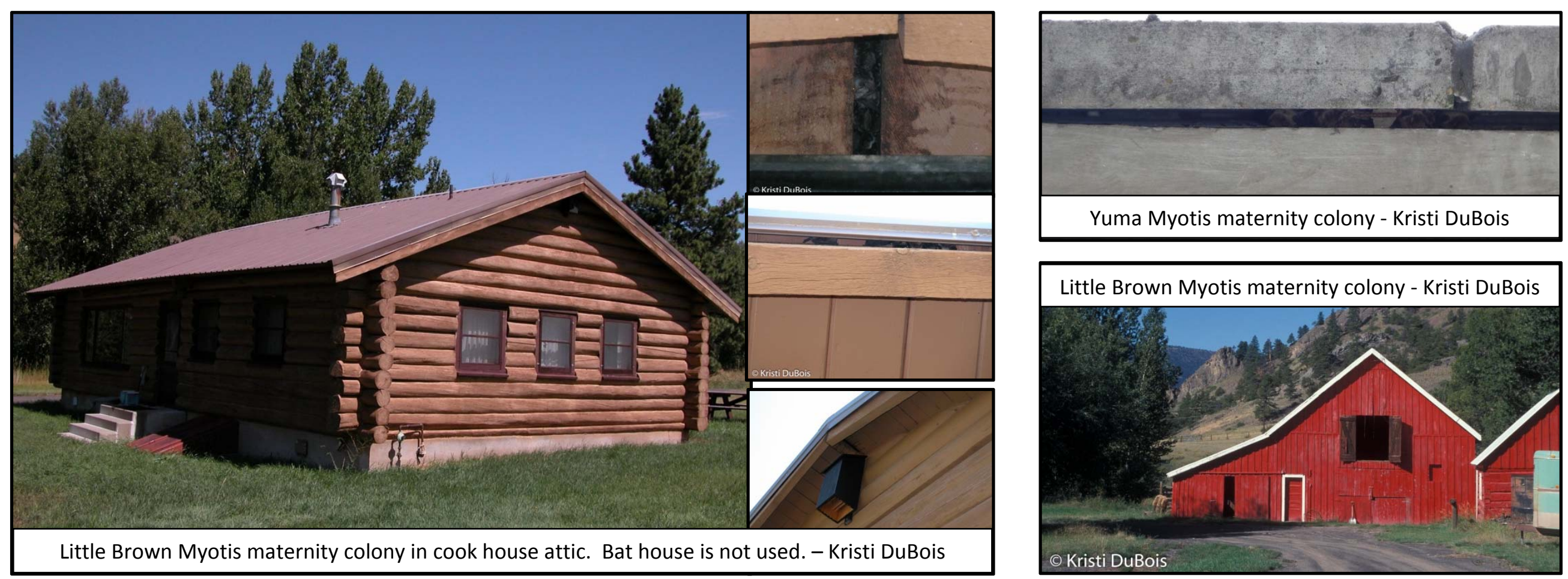

Little Brown Myotis maternity colony in cook house attic. Bat house is not used. - Kristi DuBois

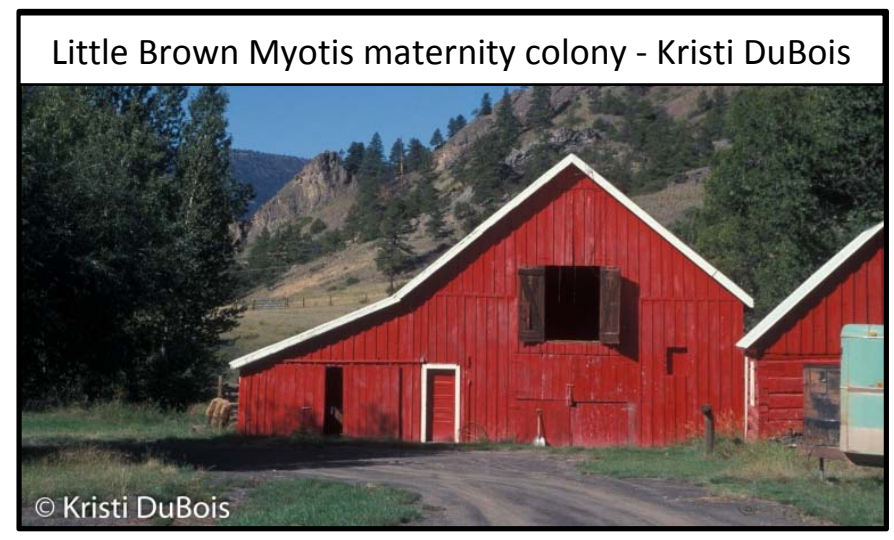

Big Brown Bat maternity colony in house attic - Bryce Maxell

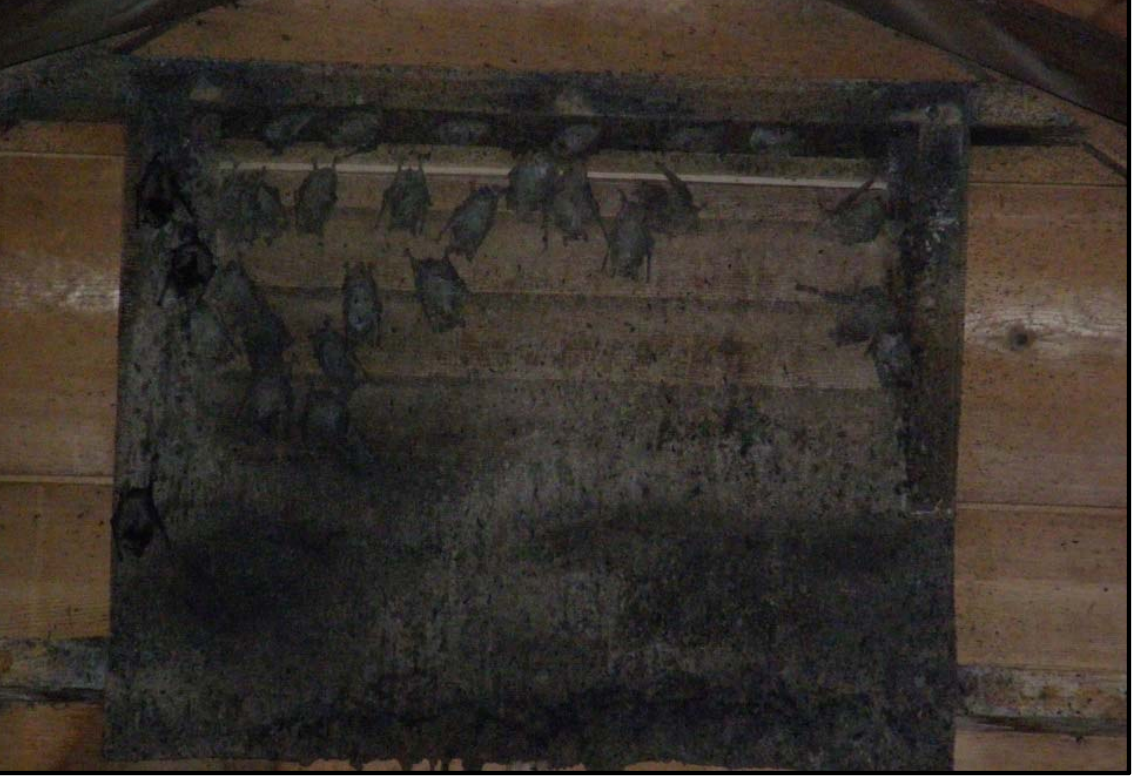

Unidentified Myotis maternity colony in interstate highway bridge expansion joint - Bryce Maxell

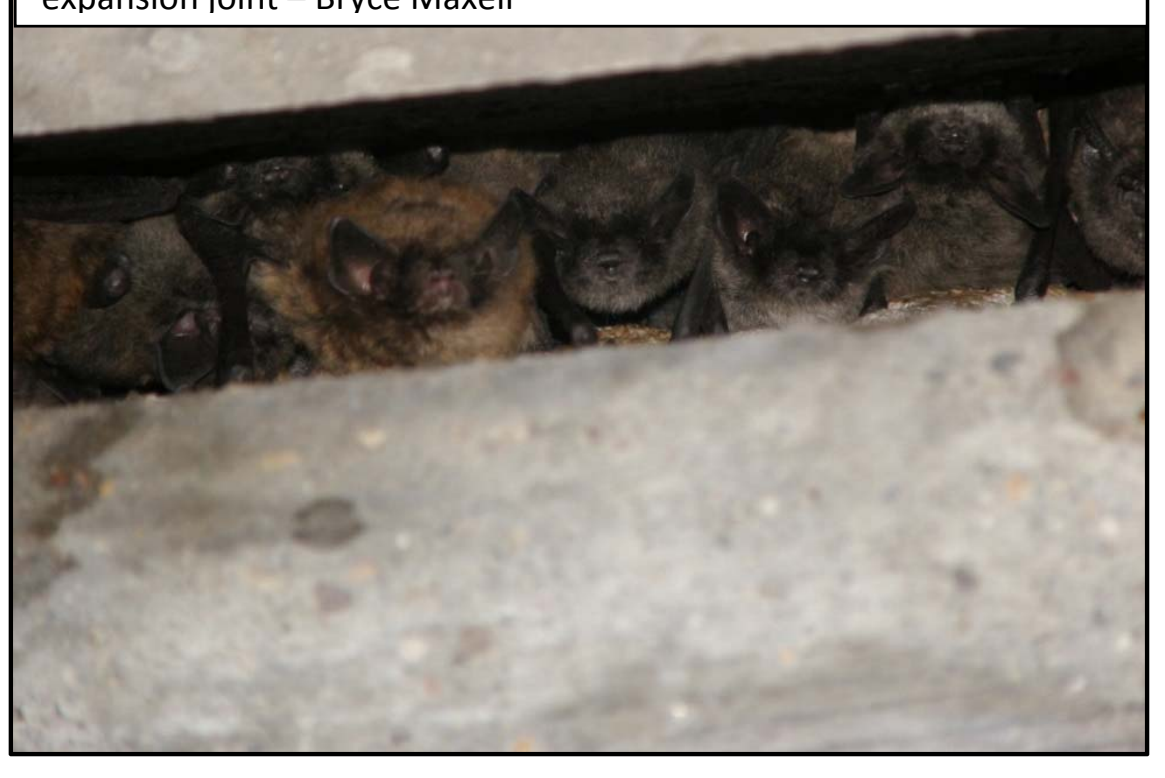




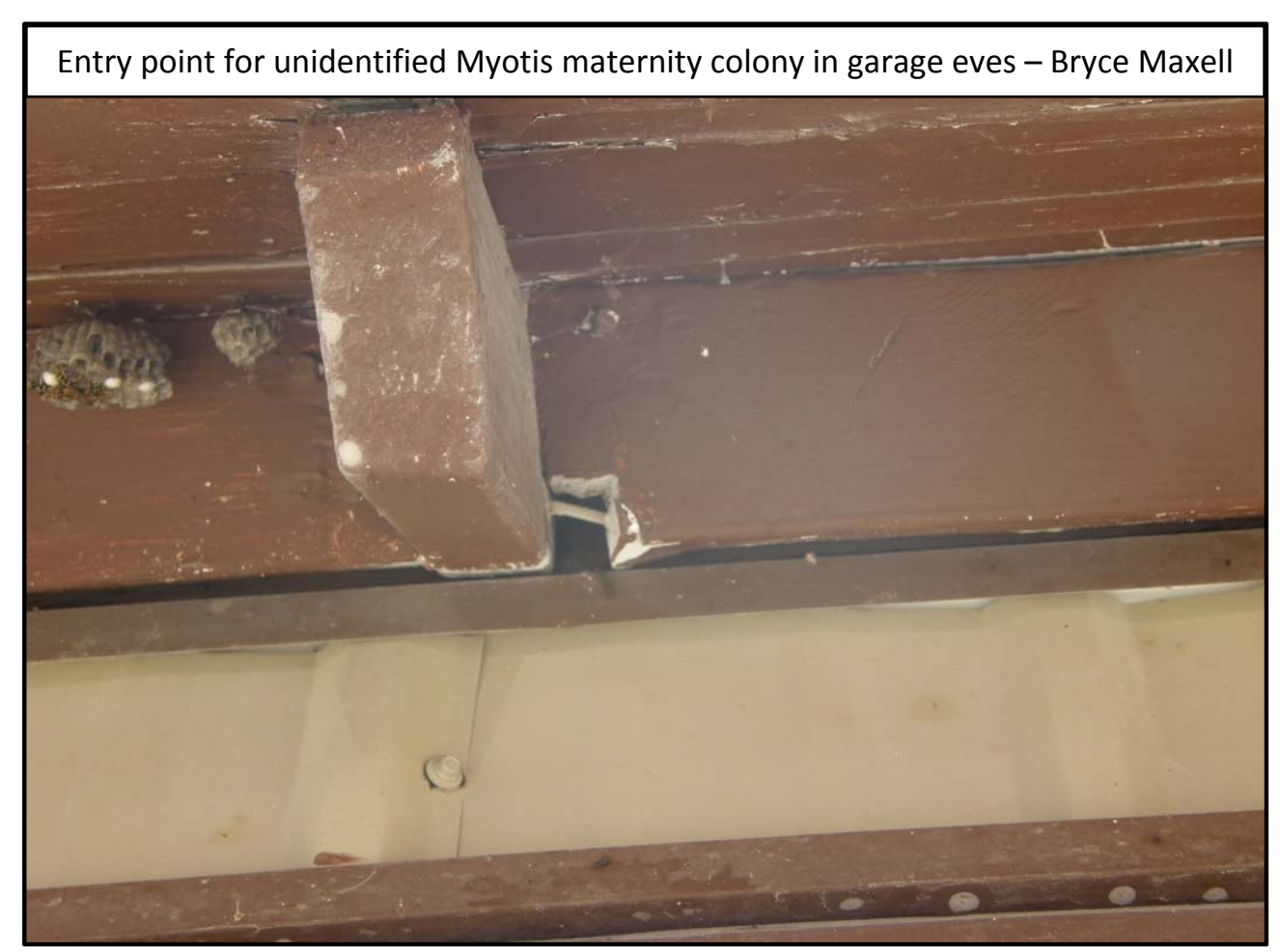

Droppings from Little Brown Myotis maternity colony - Kristi DuBois

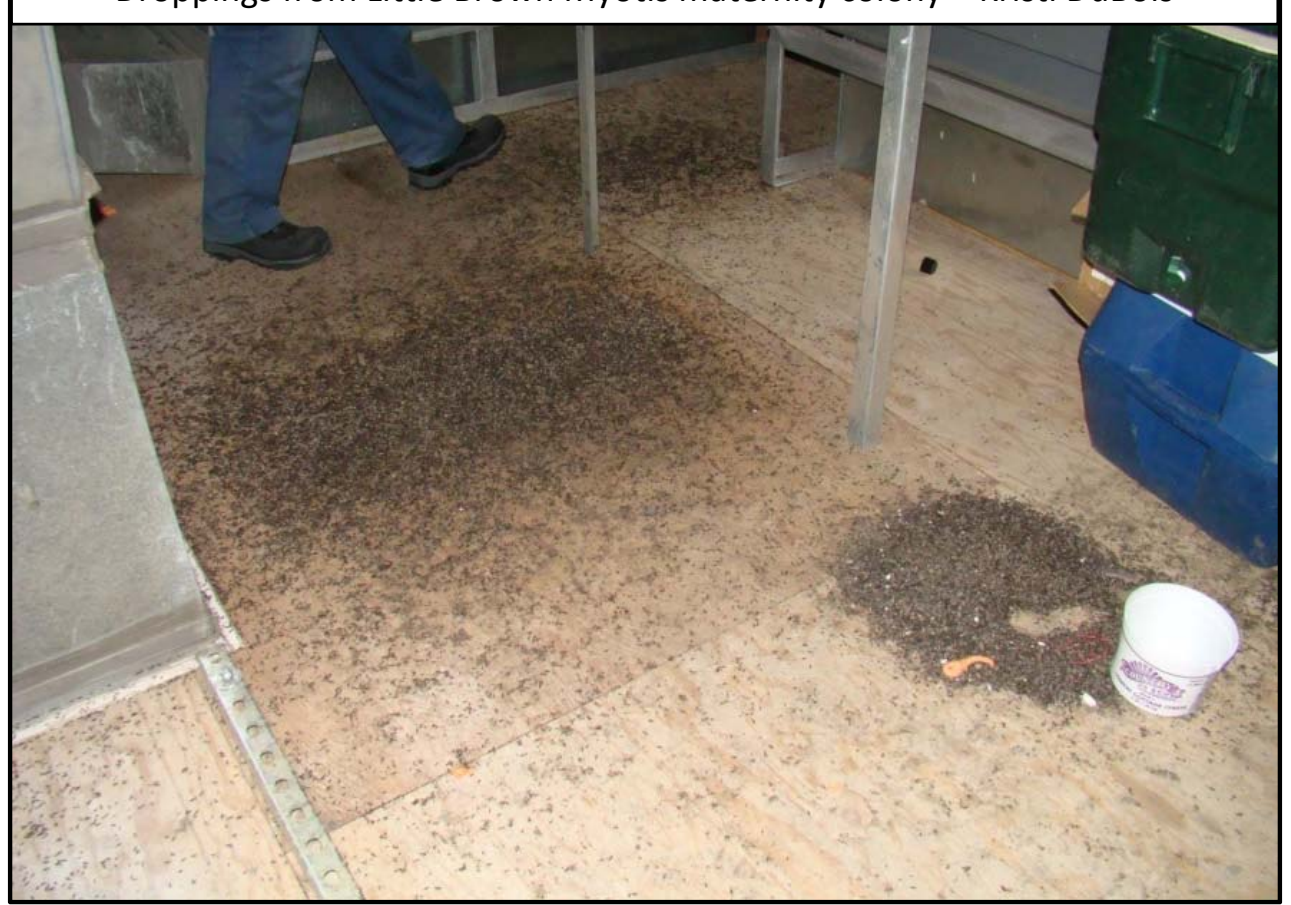

Eve entry points for Little Brown Myotis maternity colony - Kristi DuBois

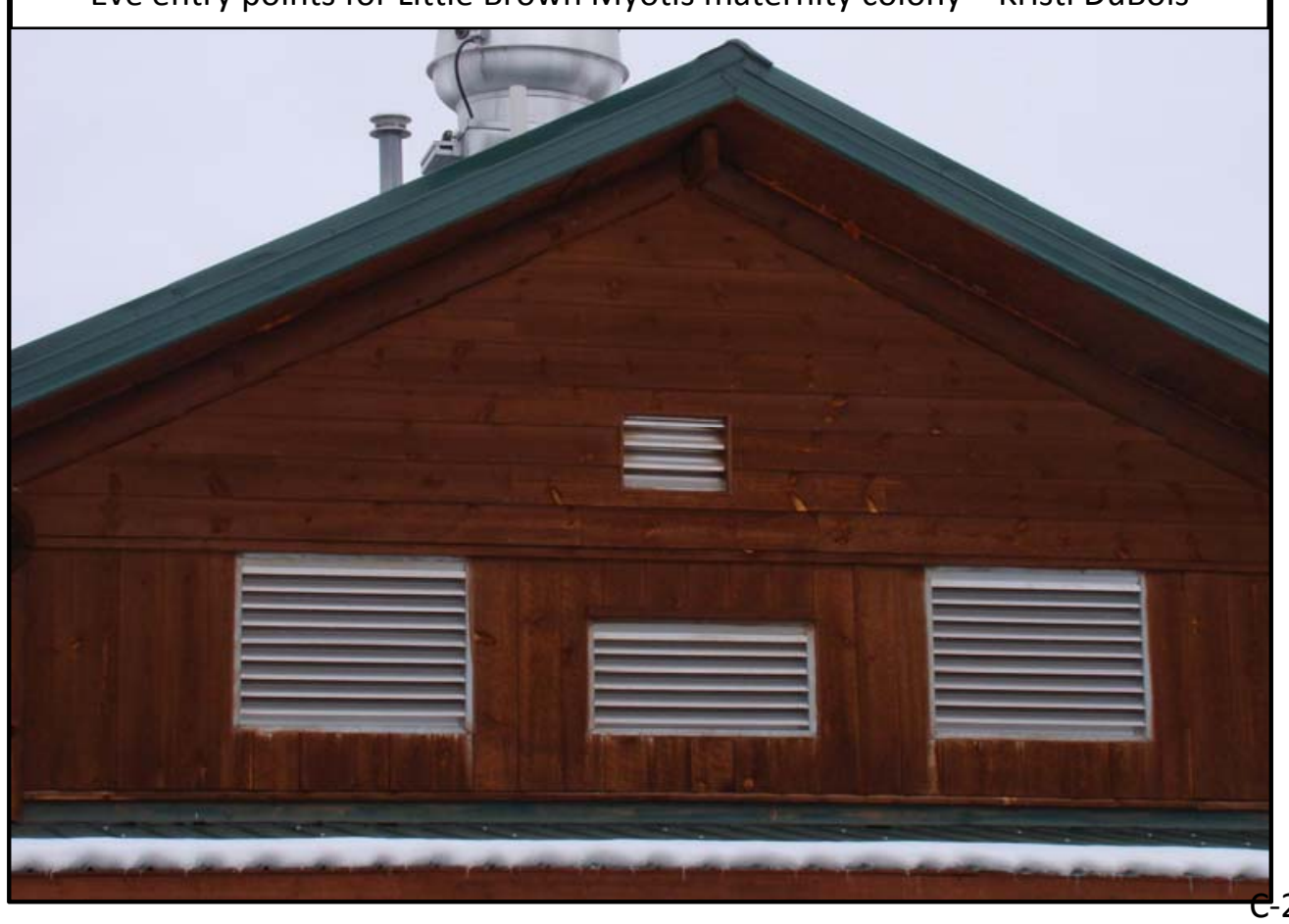

Big Brown Bat maternity colony on metal barn rafters - Adam Messer

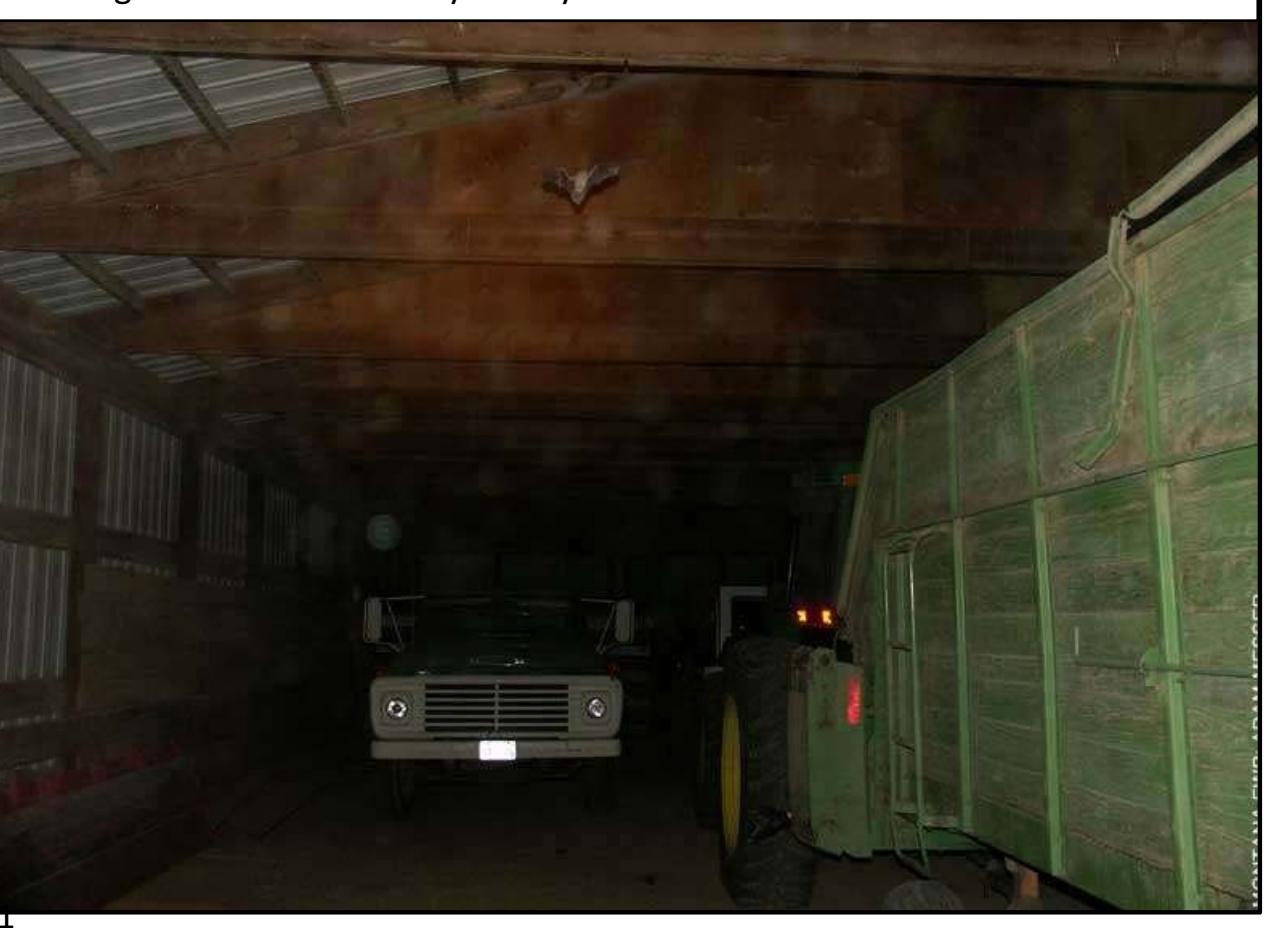




\section{Examples of Summer Night and Day Roosts for Montana Bats}

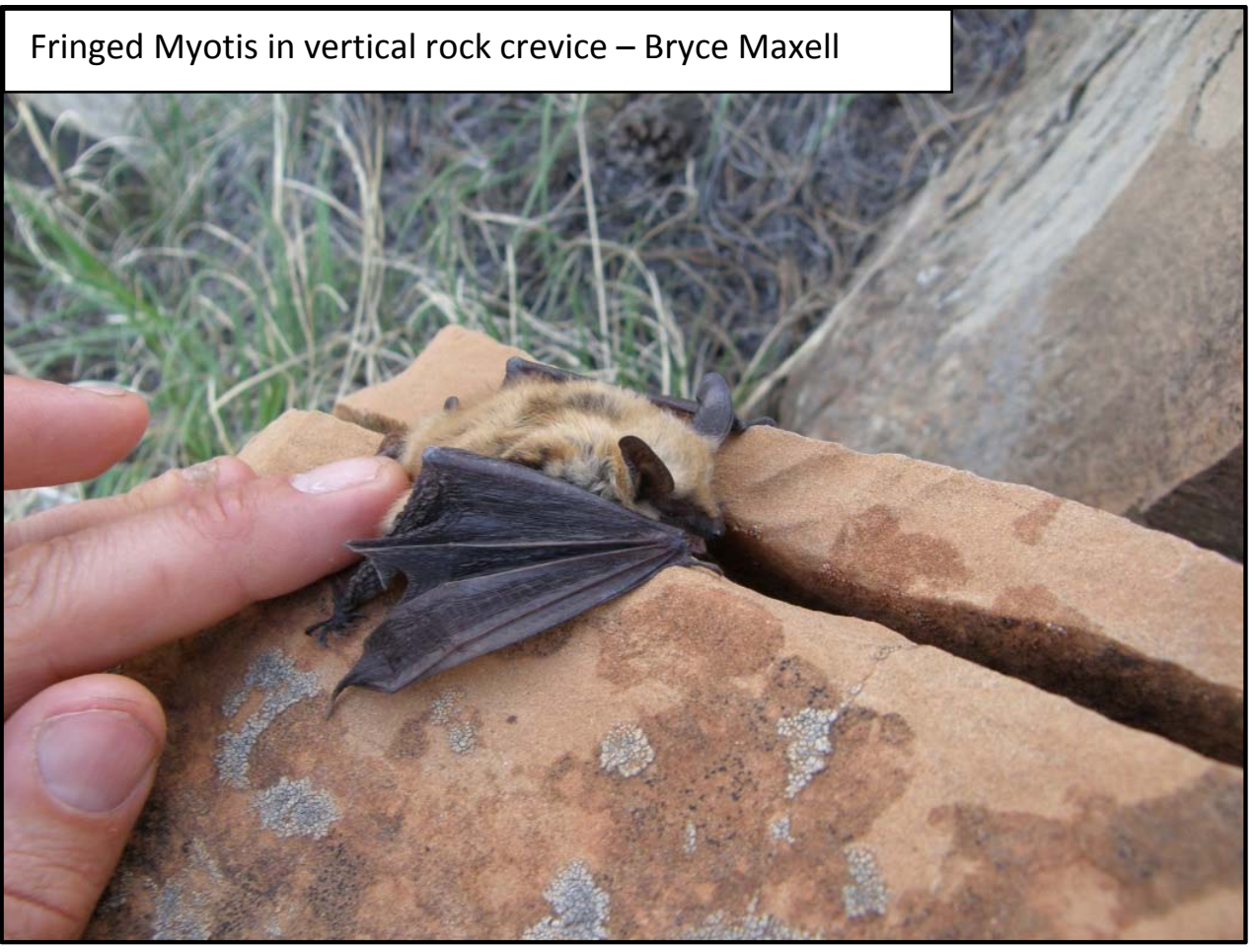

Pallid Bat under slab rock - Keaton Wilson
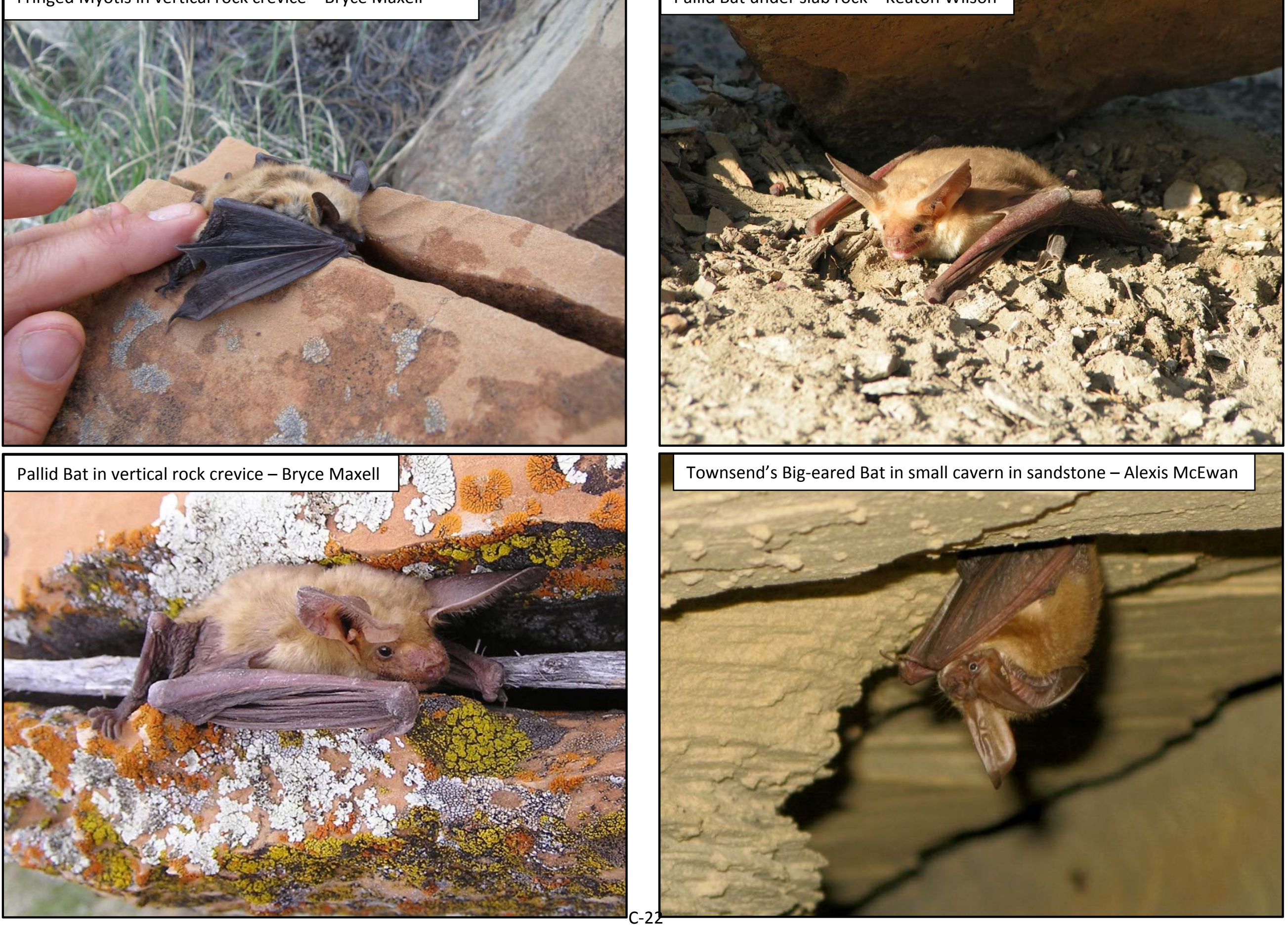

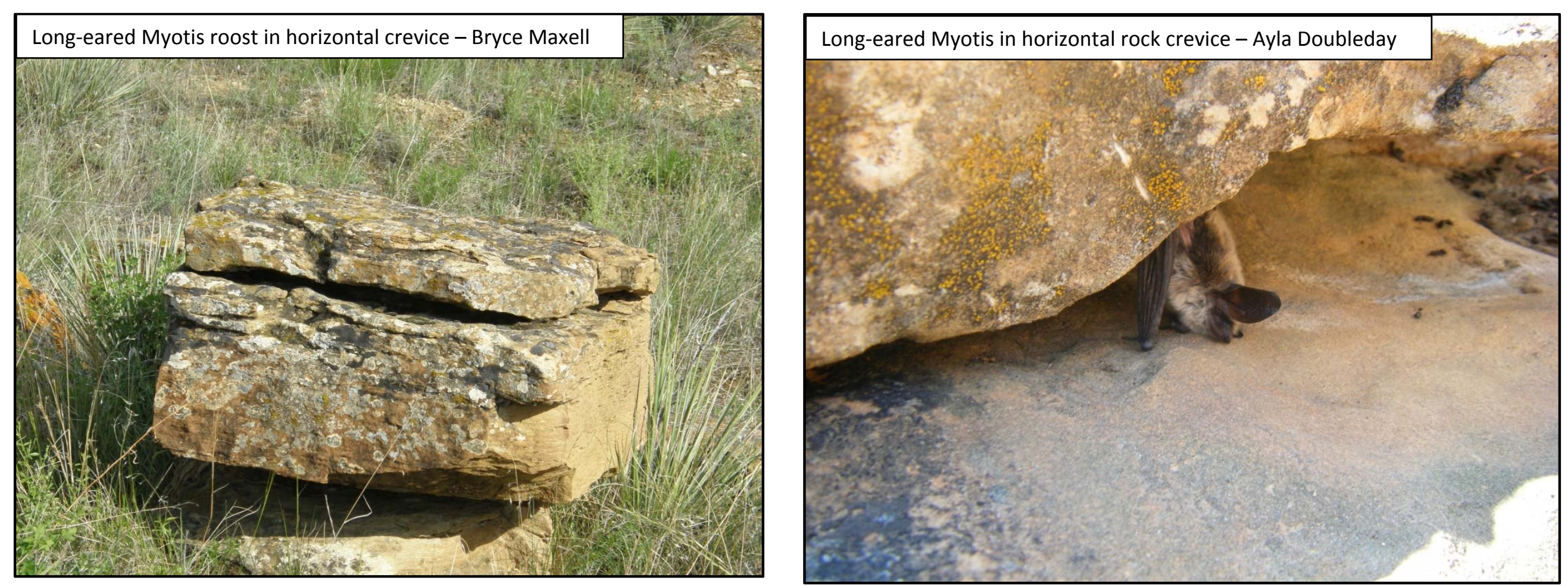

Western Small-footed Myotis under slab rock - Bryce Maxell

Big Brown Bat in horizontal rock crevice - Alexis McEwan
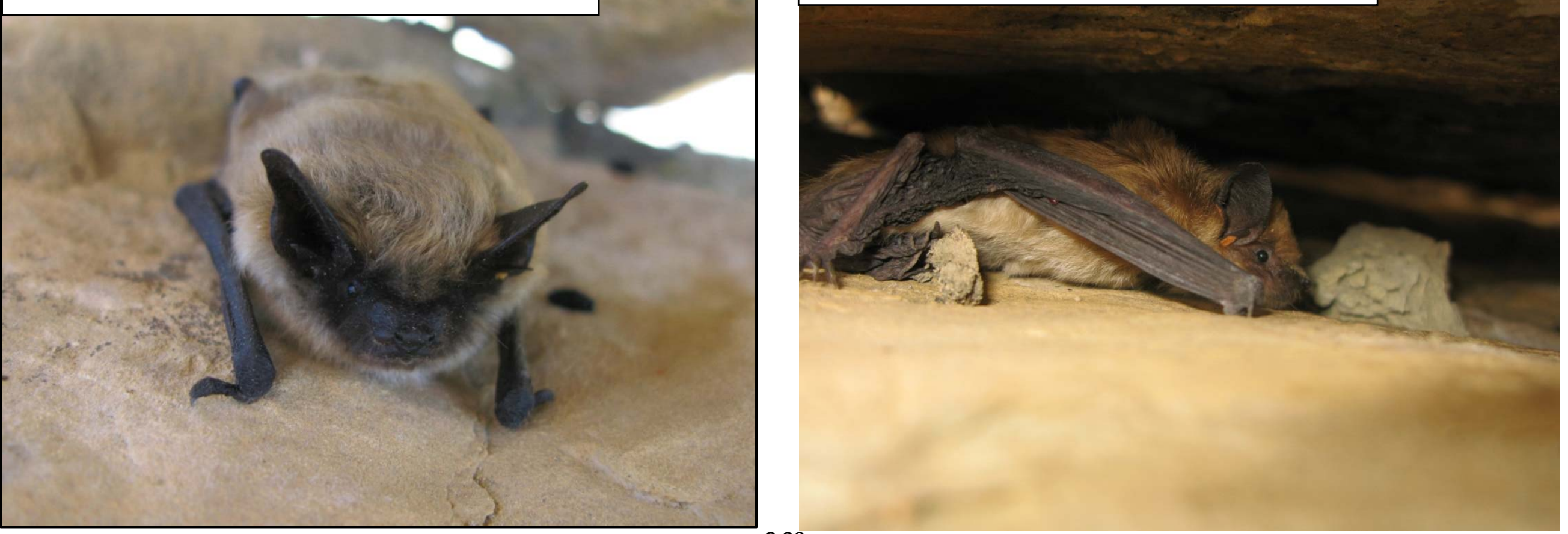

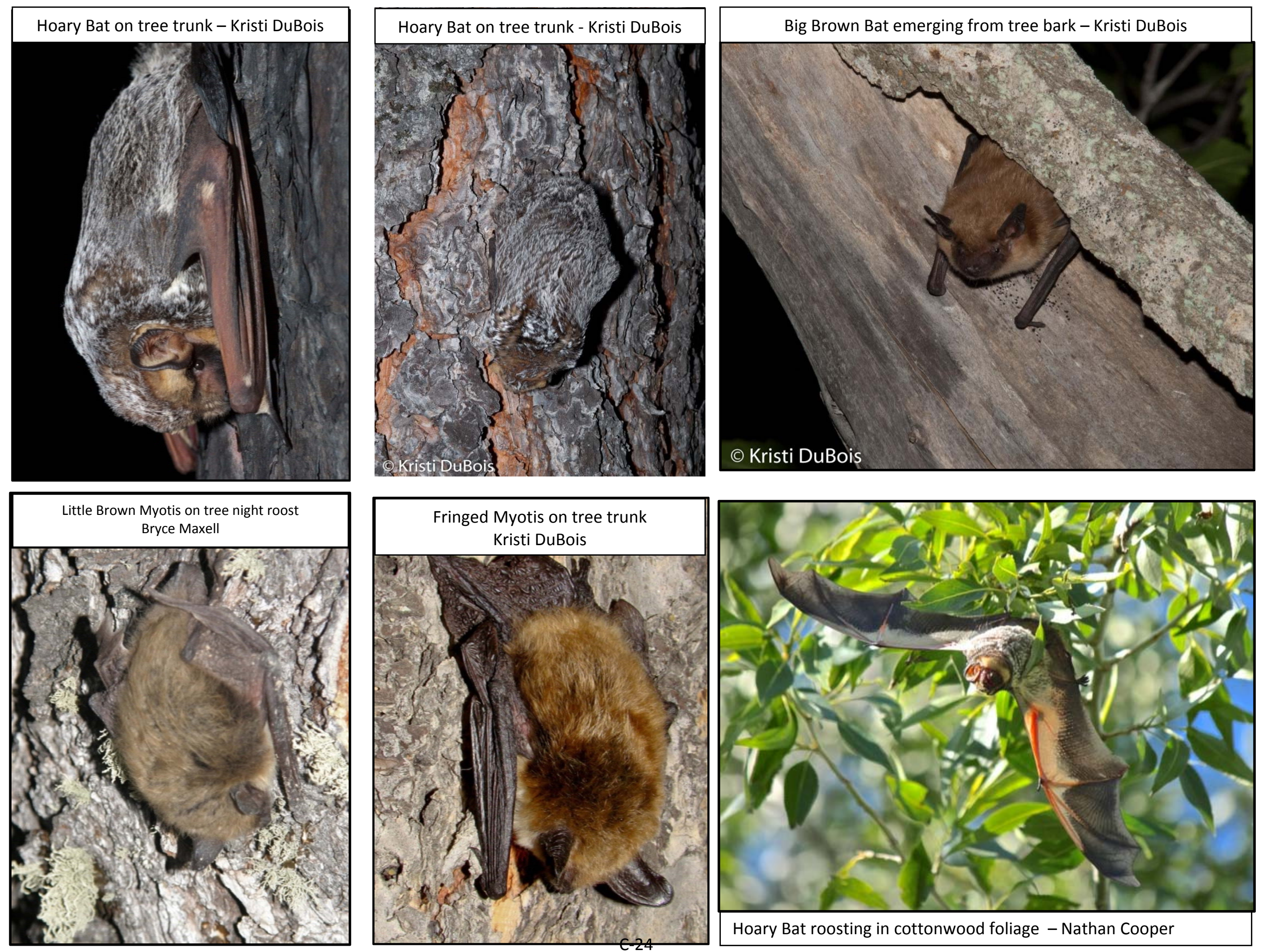

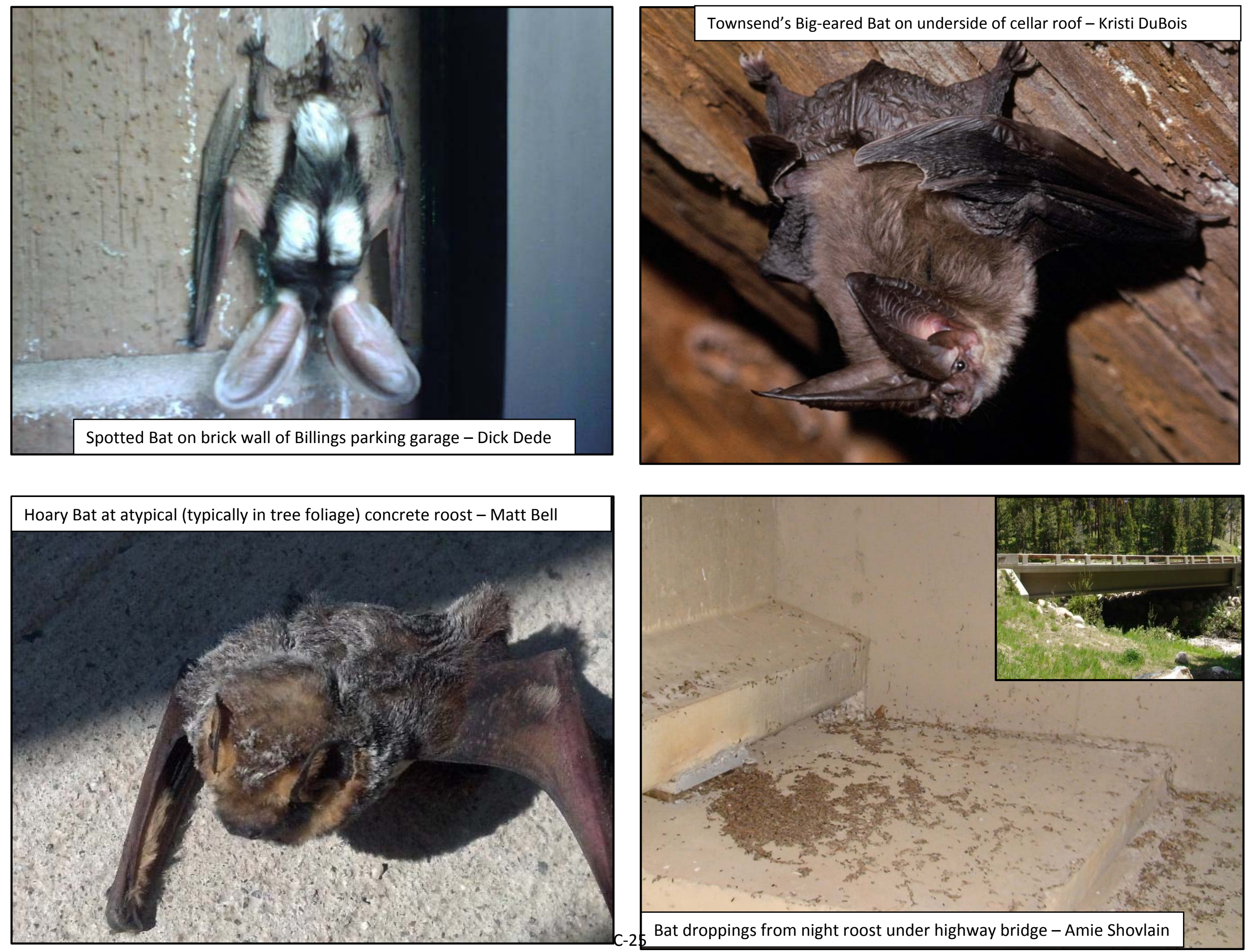
Western Small-footed Myotis on brick wall with good solar exposure - Bryce Maxell

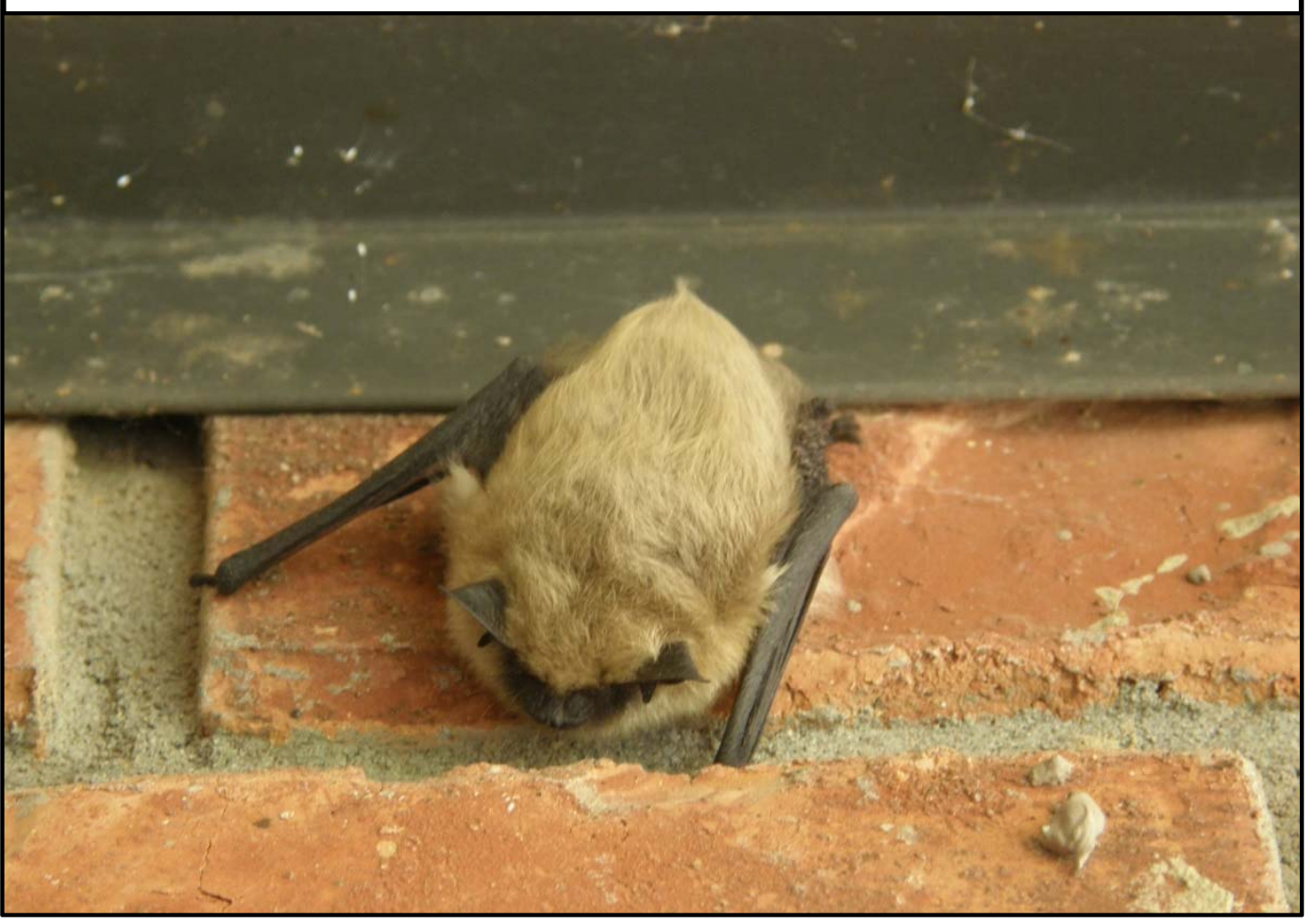

Little Brown Myotis pup in crack of log cabin - Kristi DuBois

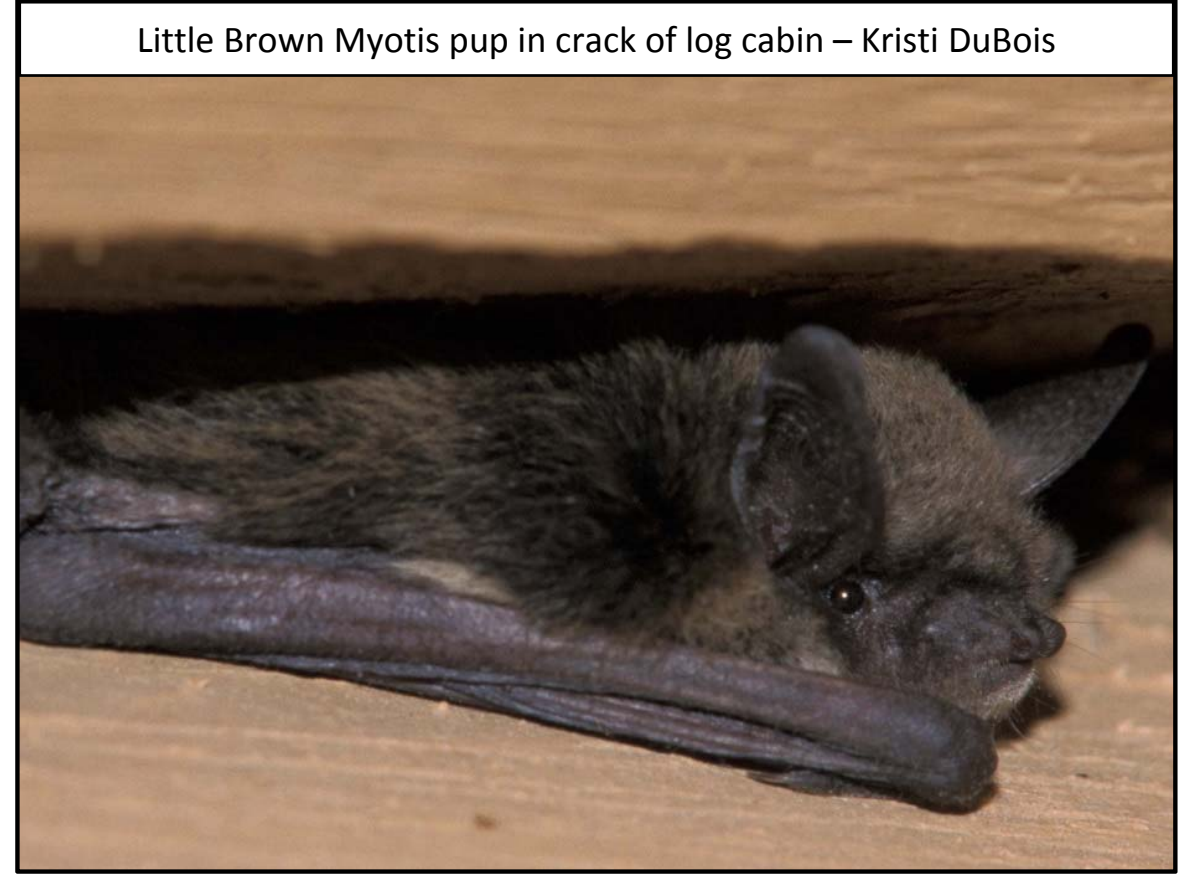

Big Brown Bat in highway expansion joint crevice - Bryce Maxell
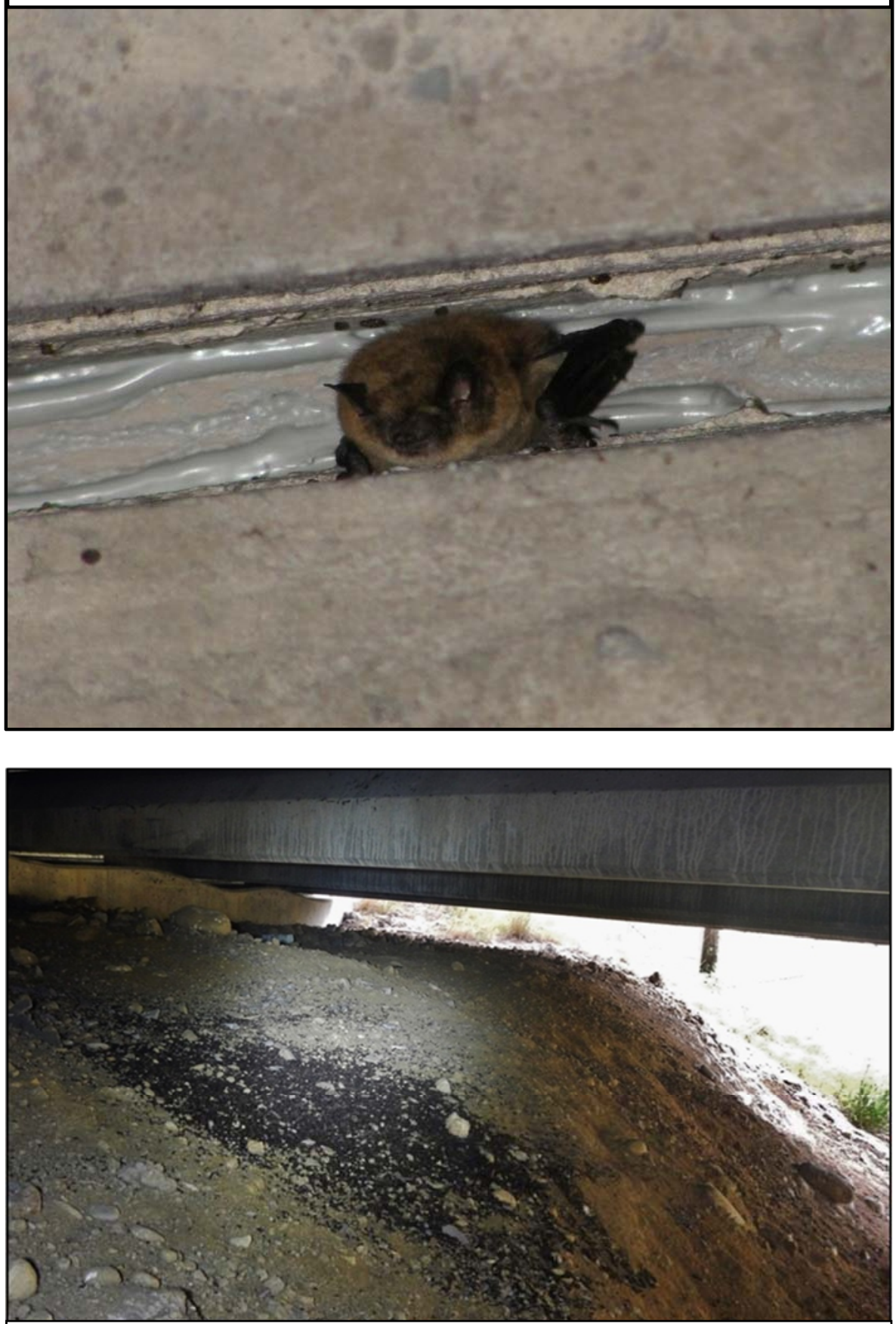

Droppings under bridge. Sometimes large volumes of droppings result only from night roosting near foraging areas - Ellen Whittle 


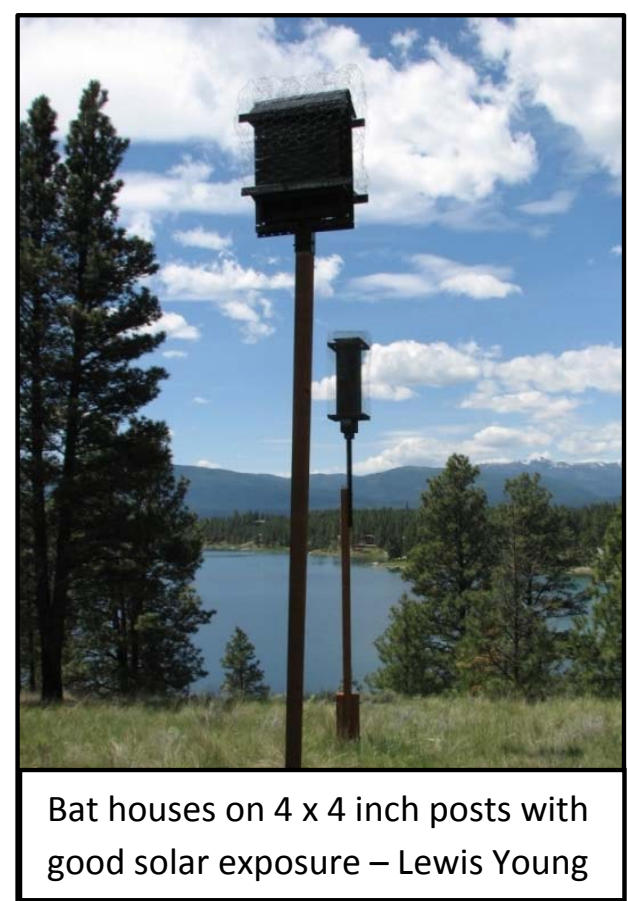

\section{Examples of Artificial Summer Roosts (Bat Houses)}
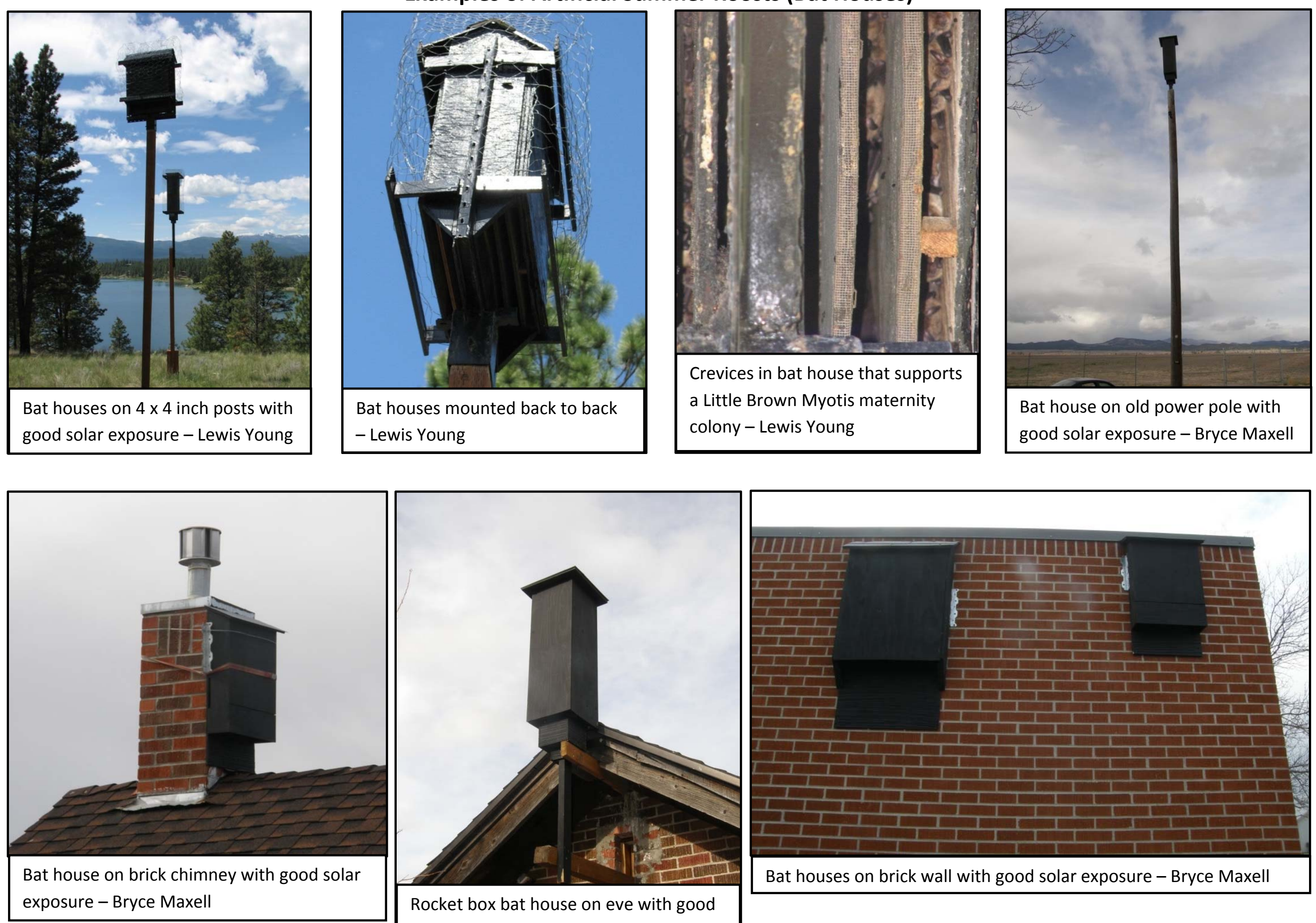

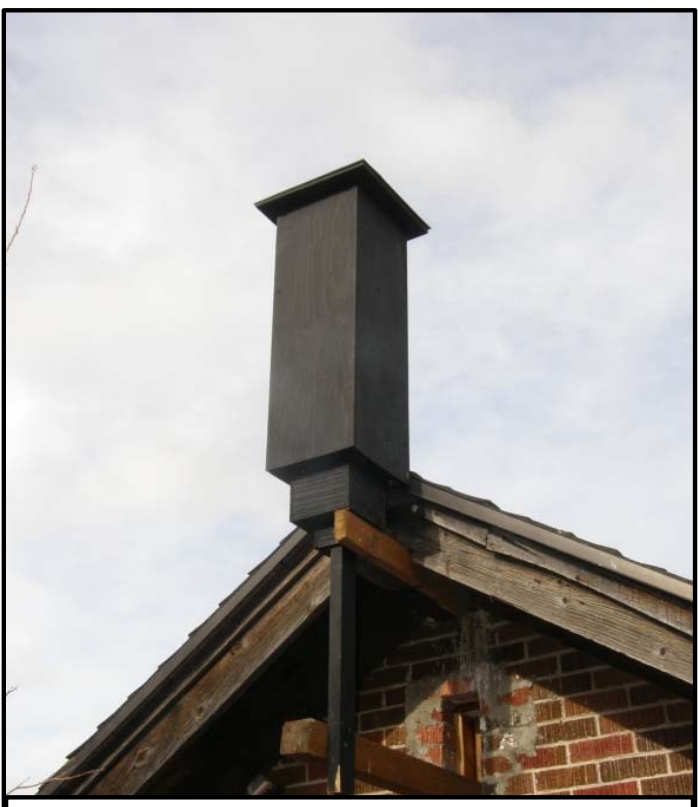

Rocket box bat house on eve with good solar exposure - Bryce Maxell

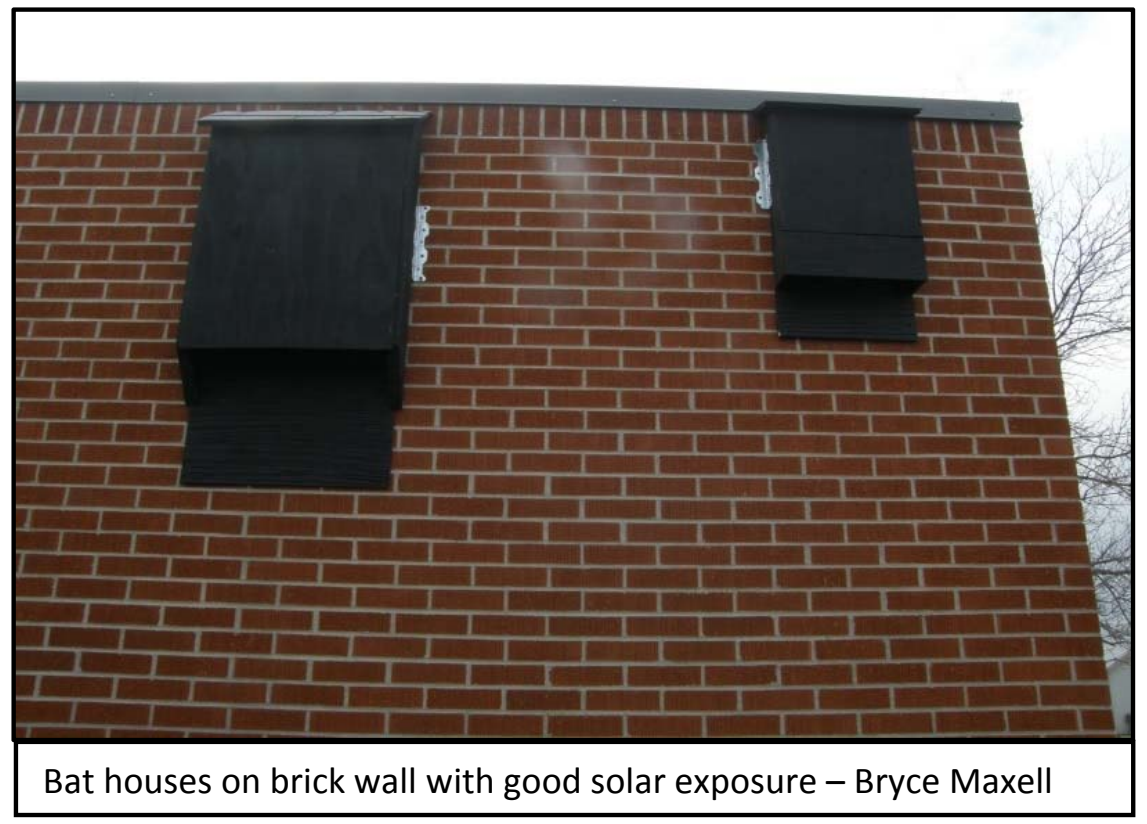

